\title{
Anhydrite Deposits of the United States and Characteristics of Anhydrite Important for Storage of Radioactive Wastes
}

\section{U.S. GEOLOGICAL SURVEY BULLETIN 1794}


Instructions on ordering publications of the U.S. Geological Survey, along with prices of the last offerings, are given in the current-year issues of the monthly catalog "New Publications of the U.S. Geological Survey." Prices of available U.S. Geological Survey publications released prior to the current year are listed in the most recent annual "Price and Availability List." Publications that are listed in various U.S. Geological Survey catalogs (see back inside cover) but not listed in the most recent annual "Price and Availability List" are no longer available.

Prices of reports released to the open files are given in the listing "U.S. Geological Survey Open-File Reports," updated monthly, which is for sale in microfiche from the U.S. Geological Survey, Books and Open-File Reports Section, Federal Center, Box 25425, Denver, CO 80225. Reports released through the NTIS may be obtained by writing to the National Technical Information Service, U.S. Department of Commerce, Springfield, VA 22161; please include NTIS report number with inquiry.

Order U.S. Geological Survey publications by mail or over the counter from the offices given below.

\section{BY MAIL}

\section{Books}

Professional Papers, Bulletins, Water-Supply Papers, Techniques of Water-Resources Investigations, Circulars, publications of general interest (such as leaflets, pamphlets, booklets), single copies of Earthquakes \& Volcanoes, Preliminary Determination of Epicenters, and some miscellaneous reports, including some of the foregoing series that have gone out of print at the Superintendent of Documents, are obtainable by mail from

\section{U.S. Geological Survey, Books and Open-File Reports Federal Center, Box 25425 Denver, CO 80225}

Subscriptions to periodicals (Earthquakes \& Volcanoes and Preliminary Determination of Epicenters) can be obtained ONLY from the

\section{Superintendent of Documents \\ Government Printing Office \\ Washington, D.C. 20402}

(Check or money order must be payable to Superintendent of Documents.)

\section{Maps}

For maps, address mail orders to

\section{U.S. Geological Survey, Map Distribution \\ Federal Center, Box 25286 \\ Denver, CO 80225}

Residents of Alaska may order maps from

\author{
Alaska Distribution Section, U.S. Geological Survey, \\ New Federal Building - Box 12 \\ 101 Twelfth Ave., Fairbanks, AK 99701
}

\section{OVER THE COUNTER}

\section{Books}

Books of the U.S. Geological Survey are available over the counter at the following Geological Survey Public Inquiries Offices, all of which are authorized agents of the Superintendent of Documents:

- WASHINGTON, D.C.--Main Interior Bldg., 2600 corridor, 18 th and C Sts., NW.

- DENVER, Colorado--Federal Bldg., Rm. 169, 1961 Stout St.

- LOS ANGELES, California--Federal Eldg., Rm. 7638, 300 N. Los Angeles St.

- MENLO PARK, California--Bldg. 3 (Stop 533), Rm. 3128, 345 Middlefield Rd.

- RESTON, Virginia--503 National Center, Rm. 1C402, 12201 Sunrise Valley Dr.

- SALT LAKE CITY, Utah--Federal Bldg., Rm. 8105, 125 South State St.

- SAN FRANCISCO, California--Customhouse, Rm. 504, 555 Battery St.

- SPOKANE, Washington--U.S. Courthouse, Rm. 678, West 920 Riverside Ave..

- ANCHORAGE, Alaska--Rm. 101, 4230 University Dr.

- ANCHORAGE, Alaska--Federal Bldg, Rm. E-146, 701 C St.

\section{Maps}

Maps may be purchased over the counter at the U.S. Geological Survey offices where books are sold (all addresses in above list) and at the following Geological Survey offices:

- ROLLA, Missouri--1400 Independence Rd.

- DENVER, Colorado--Map Distribution, Bldg. 810, Federal Center

- FAIRBANKS, Alaska--New Federal Bldg., 101 Twelfth Ave. 


\section{Anhydrite Deposits of the United States and Characteristics of Anhydrite Important for Storage of Radioactive Wastes}

Edited by WALTER E. DEAN and KENNETH S. JOHNSON With Introduction and Discussion

By WALTER E. DEAN, KENNETH S. JOHNSON, and SERGE GONZALES

and sections on

Distribution and Geologic Characteristics of Anhydrite Deposits in the United States

By KENNETH S. JOHNSON, SERGE GONZALES, and WALTER E. DEAN

Physical Properties of Anhydrite

By SHARON F. DIEHL and WILLIAM Z. SAVAGE

Hydrogeology of Anhydrite

By WILLIAM THORDARSON

Chemical Properties of Anhydrite

By ROBERT W. POTTER II and MICHAEL A. CLYNNE

An inventory of the geologic, physical, hydrologic, and chemical characteristics of anhydrite deposits in the United States and evaluation of anhydrite as a possible medium for the storage of radioactive wastes 


\title{
DEPARTMENT OF THE INTERIOR
}

\author{
MANUEL LUJAN, JR., Secretary
}

\author{
U. S. GEOLOGICAL SURVEY \\ Dallas L. Peck, Director
}

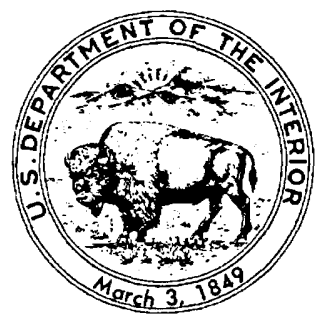

For sale by the Books and Open-File Reports Section U.S. Geological Survey

Federal Center

Box 25425

Denver, CO 80225

Any use of trade names in this report is for descriptive purposes only and does not imply endorsement by the U.S. Geological Survey

\section{Library of Congress Cataloging-in-Publication Data}

Anhydrite deposits of the United States and characteristics of anhydrite important for storage of radioactive wastes.

(U.S. Geological Survey bulletin ; 1794)

Bibliography: $p$.

Supt. of Docs. no.: । 19.3:1794

1. Anhydrite-United States. 2. Radioactive waste disposal in the ground-United States. I. Dean, Walter, E. II. Johnson, Kenneth Sutherland, 1934- III. Series.

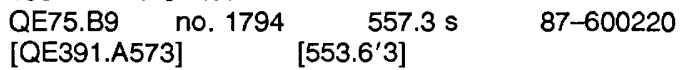




\title{
CONTENTS
}

\author{
ABSTRACT 1 \\ SECTION 1. INTRODUCTION AND DISCUSSION by Walter E. Dean, \\ Background 3 \\ Kenneth S. Johnson, and Serge Gonzales 3 \\ Regional geologic characteristics important for waste storage 4 \\ Structure and geologic framework 4 \\ Dip or inclination of strata 4 \\ Faults and joints 4 \\ Nature and extent of adjacent strata 5 \\ Anhydrite deposits 5 \\ Depth of storage zone 5 \\ Thickness and extent 5 \\ Homogeneity 5 \\ Dissolution 6 \\ Hydrology 6 \\ Surface water 6 \\ Ground water 7 \\ Mineral resources 7 \\ Origin of evaporite deposits 7 \\ SECTION 2. DISTRIBUTION AND GEOLOGIC CHARACTERISTICS OF
ANHYDRITE DEPOSITS IN THE UNITED STATES, by
Kenneth S. Johnson, Serge Gonzales, and Walter E. Dean 9 \\ Summary 9 \\ Michigan basin 16 \\ Structure and geologic framework 16 \\ Salina Group 17 \\ Lucas Formation of Detroit River Group \\ 19 \\ Michigan Formation 23 \\ Appalachian basin-Salina Group $\mathbf{2 4}$ \\ Adirondack uplift-Precambrian $\mathbf{2 6}$ \\ Saltville area (Virginia)-Maccrady Formation 27 \\ Illinois basin-St. Louis Limestone $\mathbf{2 8}$ \\ Forest City basin-Devonian, Mississippian, and Jurassic 28 \\ South Florida basin-Cretaceous and Tertiary 29 \\ Gulf Coast basin 31 \\ Structure and geologic framework 31 \\ Salt-dome cap rock 33 \\ Werner Formation 39 \\ Buckner Formation $\mathbf{4 0}$ \\ Ferry Lake Anhydrite $\mathbf{4 2}$ \\ Central Texas region-Edwards Limestone and McKnight Formation $\mathbf{4 4}$ \\ Permian basin $\mathbf{4 4}$ \\ Structure and geologic framework 44
}


Permian basin-Continued

Wellington Formation and Wichita Group $\quad 47$

Lower evaporites of Clear Fork Group $\quad 49$

Cimarron anhydrite and upper evaporites of Clear Fork Group

Yeso Formation and Briggs Formation 49

San Andres Limestone and Blaine Formation $\mathbf{5 0}$

Artesia Group $\mathbf{5 1}$

Cloud Chief Formation $\mathbf{5 1}$

Castile Formation $\mathbf{5 2}$

Salado Formation $\mathbf{5 8}$

Rustler Formation and Alibates Dolomite Lentil $\quad \mathbf{5 8}$

Northern Denver basin-Pennsylvanian through Triassic $\quad 60$

Wyoming basins-Pennsylvanian through Jurassic 62

Williston basin-Ordovician through Jurassic 65

Sweetgrass Arch-Three Forks Formation and other Devonian units 66

Eagle basin-Eagle Valley Evaporite 69

Paradox basin-Paradox Member of Hermosa Formation $\quad 70$

San Juan basin-Todilto Formation $\mathbf{7 2}$

Supai salt basin-Supai Formation $\mathbf{7 6}$

Basin and Range Province of Arizona and southern Nevada 78

Structure and geologic framework 78

Picacho basin-Miocene evaporites 79

Chandler basin-Miocene evaporites $\mathbf{8 2}$

Phoenix basin-Luke Salt Member 84

Red Rock basin-Miocene evaporites 85

Tucson basin-Miocene evaporites $\mathbf{8 5}$

Virgin Valley basin-Muddy Creek Formation 85

Other basins in Arizona 86

Southern Nevada and nearby areas-Permian through Tertiary

Central Utah-Jurassic and Tertiary $\mathbf{8 8}$

Eastern Great Basin-Permian $\mathbf{8 8}$

Northwestern Nevada-Triassic or Jurassic $\mathbf{8 9}$

Western Idaho and eastern Oregon-Triassic $8 \mathbf{8 9}$

Southern California-Tertiary $\mathbf{8 9}$

SECTION 3. PHYSICAL PROPERTIES OF ANHYDRITE,

Introduction 91

by Sharon F. Diehl and William Z. Savage 91

Thermal properties $\quad 92$

Mechanical properties 92

Elastic properties 93

Discussion 93

SECTION 4. HYDROGEOLOGY OF ANHYDRITE, by William Thordarson 95

Porosity, hydraulic conductivity, and transmissivity of anhydrite Hydraulic characteristics of bedded anhydrite 95 Intercrystalline porosity and hydraulic conductivity 
Porosity, hydraulic conductivity, and transmissivity of anhydrite-Continued

Hydraulic characteristics of bedded anydrite-Continued

Fracture porosity and hydraulic conductivity 95

Hydraulic characteristics of anhydrite in cap rock of salt domes $\mathbf{1 0 2}$

Intercrystalline porosity in cap rock of salt domes 102

Fracture porosity in cap rock of salt domes $\mathbf{1 0 2}$

General hydrogeology of anhydrite $\mathbf{1 0 3}$

Dissolution of anhydrite and interbedded salt $\quad 104$

Hydration of anhydrite to gypsum 104

Data from springs 105

Summary and conclusions $\quad \mathbf{1 0 5}$

\section{SECTION 5. CHEMICAL PROPERTIES OF ANHYDRITE,}

Introduction $\mathbf{1 0 7}$ by Robert W. Potter II and Michael A. Clynne 107

Thermochemistry of anhydrite and related phases $\quad 107$

Crystallography of anhydrite and related phases 109

Phase-equilibria and solubility relationships 110

Kinetics of reactions involving anhydrite $\mathbf{1 1 2}$

Sorption of radionuclides by anhydrite $\mathbf{1 1 3}$

Radiation effects on the chemistry of anhydrite 113

Summary 114

REFERENCES CITED $\mathbf{1 1 7}$

\section{FIGURES}

2.1-2.4. Maps showing:

2.1. Anhydrite deposits in the conterminous United States 9

2.2. Major sedimentary basins in the conterminous United States

2.3. Areas in the conterminous United States where thick beds of anhydrite are present at moderate depths $\mathbf{1 1}$

2.4. Distribution and depth below land surface of Silurian and Devonian evaporite deposits in the Michigan and Appalachian basins 16

2.5. Section showing stratigraphic succession in Michigan $\mathbf{1 7}$

2.6. Generalized north-south cross section through the Michigan basin 18

2.7. Diagram showing distribution of anhydrite and other facies near pinnacle reefs in northern and southeastern parts of Michigan basin 19

2.8. Section showing stratigraphic sequence of part of Detroit River Group in the Michigan basin as determined from gamma-ray and neutron logs 20

2.9. Photographs of nodular, pillar, and massive anhydrite from the Richfield Member of the Lucas Formation in the Michigan basin 21

2.10. Photographs of reticulate, contorted, lamellar, and nodular anhydrite from the Lucas Formation and the Dundee Limestone, Michigan basin 
FIGURES-Continued

2.11 Section showing stratigraphic sequence and gypsum deposits in the Mississippian Michigan Formation of the Michigan basin as determined from spontaneous potential and resistivity logs 23

2.12. Generalized columnar sections of Salina Group in northeast Ohio and south-central New York 25

2.13. Map showing thickness, in feet, and depth to the G-unit anhydrite at top of Salina Group in the Appalachian basin $\mathbf{2 6}$

2.14. Generalized north-south cross section in northeastern Ohio 27

2.15. Generalized stratigraphic section showing evaporite units in the lower part of the St. Louis Limestone in southwest Indiana $\mathbf{2 8}$

2.16. Structural cross section showing thickening of Lower Cretaceous and lower Tertiary carbonate-anhydrite sequences into the South Florida basin

2.17. Generalized geologic column of Lower Cretaceous strata in the South Florida basin $\mathbf{3 0}$

2.18. Generalized stratigraphic sections showing lithology representative of Paleocene strata from southeastern Alabama to the South Florida basin 31

2.19. Structure map on top of Lower Cretaceous strata in Gulf Coast basin 32

2.20. Correlation chart of Jurassic and Lower Cretaceous strata in the Gulf Coast basin 33

2.21. Diagram showing generation of Gulf Coast salt domes through geologic time 34

2.22. Map showing five salt-dome basins and other principal regional structural features in Gulf Coast region $\mathbf{3 5}$

2.23. Idealized section of salt dome 36

2.24. Map showing salt domes of the Gulf Coast basin for which cap-rock data are available 37

2.25. Columnar sections showing lithologic variability of cap rock among 10 domes and on a single dome $\mathbf{3 8}$

2.26. Cross section showing Werner Formation and overlying strata in southeastern Arkansas and northeastern Louisiana. 39

2.27. Map showing thickness, in feet, and depth below land surface to top of anhydrites in Buckner Formation in southern Arkansas. $\quad 40$

2.28. North-south stratigraphic cross section showing Buckner and Smackover Formations in southern Arkansas 41

2.29. Map showing thickness, in feet, and depth below land surface to top of Ferry Lake Anhydrite in Gulf Coast area $\mathbf{4 2}$

2.30. North-south stratigraphic cross section showing the Ferry Lake Anhydrite and other units of the Lower Cretaceous Trinity Group in Caddo Parish, northwestern Louisiana, and Miller County, southwestern Arkansas 43

2.31. Map of the Permian basin of Southwestern United States showing principal tectonic provinces and boundary of area underlain by anhydrite $\mathbf{4 5}$

2.32. Paleogeographic maps of southwestern Texas and southeastern New Mexico during early and middle Ochoan time 46

2.33. Diagram showing stratigraphic relationships of major anhydrite-bearing units in the Permian basin 
2.34. Representative well logs of major Permian units containing anhydrite in the Permian basin 48

2.35. Columnar section of Permian upper Yeso Formation and lower San Andres Limestone in the San Andres Mountains of southern New Mexico 49

2.36. Map of Permian basin area showing principal facies of the San Andres and Blaine Formations $\mathbf{5 0}$

2.37. Map of the Delaware basin and surrounding region of southwestern Texas and southeastern New Mexico $\mathbf{5 3}$

2.38. Diagrammatic east-west cross section of Castile and Salado Formations from Culberson County, Tex., to Winkler County, Tex. $\mathbf{5 4}$

2.39. Map showing thickness distribution of anhydrite I member, Castile Formation 55

2.40. Map showing thickness distribution of anhydrite II member, Castile Formation 56

2.41. Diagrammatic illustration of a complete salinity cycle in the Castile Formation and lower part of the Salado Formation $\mathbf{5 7}$

2.42. Photograph of blanket dissolution breccia correlative with halite $I$ in the Castile Formation $\mathbf{5 7}$

2.43. Contour map showing depth to top of laminated anhydrite in the Castile Formation $\mathbf{5 9}$

2.44. Stratigraphic cross section in the northeastern part of the northern Denver basin 61

2.45. Columnar section of Permian, Jurassic, and Lower Cretaceous strata in Colorado part of northern Denver basin 62

2.46. Map showing major basins and uplifts in Wyoming and adjacent areas 63

2.47. Stratigraphic cross section showing Gypsum Spring Formation and adjacent strata in western part of Wind River basin, Wyoming $\quad 64$

2.48. Map of Williston basin area in northwestern United States showing structural features 65

2.49. Generalized columnar section of the Williston basin 67

2.50. Stratigraphic cross section of Sweetgrass arch area $\mathbf{6 8}$

2.51. Map showing distribution and thickness of Eagle Valley Evaporite in the Eagle basin, northwest Colorado 69

2.52. Lithology and mechanical logs showing Eagle Valley Evaporite in two wells drilled in Eagle County, Colo. 70

2.53. Index map of Paradox basin 71

2.54. Columnar section showing typical evaporite cycle of the Paradox Member of the Hermosa Formation $\mathbf{7 2}$

2.55. Structure-contour map on top of salt in Paradox Member of Hermosa Formation along Salt Valley anticline, Grand County, Utah $\mathbf{7 3}$

2.56. Cross section through Salt Valley anticline in Grand County, Utah, showing thickened Paradox salt and arching of overlying strata $\mathbf{7 4}$

2.57. Map showing distribution and depth to top of Todilto Formation in the San Juan basin area of northwestern New Mexico and southwestern Colorado $\mathbf{7 5}$

2.58. Index map of Supai salt basin and surrounding area $\mathbf{7 6}$

2.59. Generalized geologic cross section through Supai salt basin 77 


\section{FIGURES-Continued}

2.60. Composite lithologic column of upper member of the Supai Formation in Supai salt basin $\mathbf{7 8}$

2.61. Map showing thickness, in feet, of upper member of the Supai Formation 79

2.62. Detailed lithologic columns of two cores $8 \mathrm{~km}$ apart showing correlation of evaporite units in part of upper member of the Supai Formation $\mathbf{8 0}$

2.63. Map showing basins of the Basin and Range Province in Arizona and southern Nevada that contain major nonmarine evaporite deposits

2.64. Schematic cross section through Picacho basin of south-central Arizona 81

2.65. Lithologic column showing selected parts of evaporite sequence penetrated by Exxon State (74)-1 well in the Picacho basin $\mathbf{8 2}$

2.66. Graph showing percent thickness of anhydrite beds per 30-m interval of depth in the Exxon State (74)-1 well in the Picacho basin 83

2.67. Graph showing number of anhydrite beds per 30-m interval of depth in the Exxon State (74)-1 well in the Picacho basin 83

2.68. Graph showing total number of beds per 30-m interval of depth in the Exxon State (74)-1 well in the Picacho basin 84

2.69. Map showing location of gypsum deposits in southern California 90

3.1-5.7. Graphs showing:

3.1. Typical stress-strain curves for anhydrite 93

3.2. Strength of anhydrite at 10 -percent strain and different strain rates 93

5.1. Solubility relationships of calcium sulfate minerals in pure water 109

5.2. Solubility of anhydrite in pure water 109

5.3. Solubility of gypsum and anhydrite in seawater concentrates $\mathbf{1 1 0}$

5.4. Solubility of anhydrite in sodium chloride solutions at $200^{\circ}$ Celsius as a function of the molality of sodium chloride 111

5.5. Solubility of anhydrite in equilibrium with solid sodium chloride and a representative bittern brine as a function of temperature 111

5.6. Effect of pressure on the solubility of anhydrite in pure water as a function of temperature $\mathbf{1 1 2}$

5.7. Solubility of anhydrite at 1,000 bars as a function of temperature and sodium chloride concentration 112

5.8. $55^{\circ}$-isotherm of the five-component $\mathrm{NaCl}-\mathrm{KCl}-\mathrm{MgCl}_{2}-\mathrm{Na}_{2} \mathrm{SO}_{4}-\mathrm{H}_{2} \mathrm{O}$ system at sodium chloride saturation $\mathbf{1 1 3}$

5.9. $83^{\circ}$-isotherm of the five-component $\mathrm{NaCl}-\mathrm{KCl}-\mathrm{MgCl}_{2}-\mathrm{Na}_{2} \mathrm{SO}_{4}-\mathrm{H}_{2} \mathrm{O}$ system at sodium chloride saturation

114

\section{TABLES}

2.1. Summary of geologic data on anhydrite deposits in the conterminous United States $\mathbf{1 2}$

2.2. Depth and thickness of various rock types in cap rock of selected salt domes in Gulf Coast basin $\quad 38$ 


\section{TABLES-Continued}

3.1. Thermal properties of anhydrite 91

3.2. Ultimate strength of anhydrite 92

3.3. Mechanical properties of single crystals of anhydrite

3.4. Mechanical properties of whole-rock anhydrite 94

3.5. Sonic velocities of anhydrite 94

4.1. Hydrologic data from tunnels, mines, wells, and springs

4.2. Intercrystalline porosity of bedded anhydrite 101

5.1. Phases in the system $\mathrm{CaSO}_{4}-\mathrm{H}_{2} \mathrm{O} \quad 108$

5.2. Thermochemical properties of calcium sulfate phases

5.3. Kinetic reactions for which data are needed 



\title{
Anhydrite Deposits of the United States and Characteristics of Anhydrite Important for Storage of Radioactive Wastes
}

\author{
Edited by WALTER E. DEAN and KENNETH S. JOHNSON
}

\section{ABSTRACT}

All major anhydrite deposits within the conterminous United States are contained within 25 structural basins or geographic areas. These deposits are evaluated in terms of stratigraphic relationships of anhydrite to the entire deposit, thickness of the entire deposit, and relative abundance of anhydrite. Anhydrite beds thicker than 30 meters and present at moderate depths (greater than 300 meters and less than 1,500 meters) are particularly emphasized; a total of 20 anhydrite deposits contain beds that meet these criteria, at least on the basis of available literature. These deposits are characterized in terms of geologic age of the deposit, stratigraphy of the deposit, structure of the deposit, thicknesses and distributions of individual anhydrite beds, depths to individual anhydrite beds, other associated lithologies, relative purity of the anhydrite, and internal fabric of the anhydrite.

Test data on the following mechanical and thermal properties were compiled from the literature: density, porosity, thermal conductivity, sonic velocity, Young's modulus, Poisson's ratio, and shear moduli. Based on this compilation, anhydrite appears to have several advantages over halite for proposed nuclear-waste isolation. It has a higher melting point and ductile deformation occurs at higher temperatures than for halite. Its ultimate strength at low confining pressures is two to three times that of halite and anhydrite is less ductile under these conditions. However, this brittle behavior of anhydrite at low confining pressures may enhance fracturing in the vicinity of the repository.
An inventory was prepared from existing literature on the general hydrology, porosity, hydraulic conductivity, and transmissivity of anhydrite based on data obtained from outcrops, tunnels, mines, wells, and springs. The main hydrologic characteristic of anhydrite that makes it more favorable than halite as a medium for nuclear waste isolation is that it is about two orders of magnitude less soluble than halite. However, it is still a moderately soluble medium and is subject to many of the hydrologic problems that may potentially cause dissolution of salt.

Data on the thermodynamics, crystallography, phase equilibria, solubility, kinetics of reactions, sorption characteristics for radionuclides, and radiation effects of anhydrite and related phases of calcium sulfate are evaluated from the available literature. The initial chemical properties of anhydrite that suggested its use as a potential medium for nuclear-waste isolation are its low solubility (relative to halite) and retrograde nature of the solubility-that is, solubility decreases with increasing temperature. This combination of solubility characteristics mean that fluids migrate more slowly in anhydrite than in halite and migrate away from a heat source rather than toward a heat source as they do in halite. The suitability of anhydrite as a waste-disposal medium is further enhanced by the facts that it appears to have a higher sorptive capacity for radionuclides than halite, it has a thermal conductivity about as high as that of halite, and it occurs in geologic environments that have been relatively stable for tens of millions to hundreds of millions of years. 



\title{
SECTION 1. Introduction and Discussion
}

\author{
BY WALTER E. DEAN, KENNETH S. JOHNSON', and SERGE GONZALES ${ }^{2}$
}

\section{BACKGROUND}

The quantity of high-level radioactive wastes has increased in the United States and throughout the world during the past three decades because of the generation of wastes in both the manufacture of nuclear weapons and the operation of nuclear electric powerplants. The proper management of these wastes requires that they be stored or disposed of in such a way that their radionuclides will not escape into the biosphere in amounts that would constitute a biological hazard (International Atomic Energy Agency, 1977). These wastes must therefore be isolated from the biosphere for long periods of geologic time.

Many different geologic settings for either the storage or the disposal of high-level radioactive wastes have been proposed. They include the ocean seabed in either submarine-trench or abyssal-plain areas; the Antarctic ice sheet; isolated alluvial valleys in the Western United States; artificially formed "nuclear chimneys" in molten silicate rock; and mined caverns in many different rock types, such as salt (bedded salt and salt domes), clay and shale, granite, basalt, anhydrite, dry limestone (including chalk), and serpentinite. Most of the research in this country during the past 30 years has been devoted to subsurface storage in rock salt (halite), but, recently, an interest has been shown in further evaluating the other major rock types as potential storage media (Bredehoeft and others, 1978). Thus, the U.S. Geological Survey began a study of anhydrite, one of the rock types that has been considered as a potential depository for these wastes.

This investigation presents an inventory of major anhydrite deposits in the United States and describes their geologic, structural, hydrologic, physical, and geochemical characteristics that are important for evaluating anhydrite as a potential medium for disposal of high-level radioactive wastes. Although the literature on all major deposits of anhydrite has been examined and

\footnotetext{
${ }^{1}$ Oklahoma Geological Survey, Norman, Oklahoma.

${ }^{2}$ Earth Resource Associates, Inc., Athens, Georgia.
}

summarized, the emphasis of this report is on 20 deposits that contain individual beds of anhydrite more than $30 \mathrm{~m}$ (meters) thick and between 300 and $1,500 \mathrm{~m}$ beneath the Earth's surface.

This preliminary survey of existing data constitutes the first step in assessing the suitability of anhydrite as a medium for storage of radioactive wastes. However, even at this early stage, a number of characteristics of anhydrite appear to be favorable for storing of high-level radioactive wastes:

1. Many anhydrite beds have remained undisturbed and without significant dissolution or hydration for tens of millions to hundreds of millions of years, an indication of their long-term integrity.

2. Anhydrite has a rather high thermal conductivity, and hence should dissipate large quantities of heat (which would be generated by high-level wastes) more rapidly than do most rocks.

3. Although more brittle than rock salt, anhydrite nevertheless has a natural plasticity under conditions of moderate to high temperature and pressure, and thus should be capable of "self-sealing" fractures that may develop in it.

4. The solubility of anhydrite in water is lower than that of halite and most other evaporite minerals, and the solubility is retrograde (it decreases with increasing temperature); thus, fluids trapped as inclusions migrate slower in anhydrite than in halite, and should migrate away from a heat source in the temperature range at which a waste repository would be expected to operate.

5. Based on the limited data now available, the sorptive capacity of anhydrite for radionuclides appears to be significantly greater than that of halite, and even greater than that of some volcanic tuffs; this capacity would further reduce the possibility for escape of radionuclides from a waste repository.

6. Indirect evidence suggests that the effects of radiation on the chemistry of anhydrite would be minor.

7. Anhydrite deposits that are sufficiently deep and thick to be considered as potential repositories are widespread in this country and generally occur in areas that have low levels of seismicity and tectonic activity; 
thus, the potential for earthquake damage to repository surface structures and subsurface mine workings is greatly reduced.

8. Domestic anhydrite resources are so large that using one or several deposits as repositories would not adversely affect availability of anhydrite resources; repository sites far from existing mines could be selected, so proximity to mining activity would not be a problem.

9. Anhydrite can be mined at relatively low cost; technology for the underground excavation of gypsum and anhydrite is well developed, and underground rooms that have been opened in these rocks have remained stable for long periods of time where adequate pillar size was used in the mine design and where water could not enter the mine opening.

\section{REGIONAL GEOLOGIC CHARACTERISTICS IMPORTANT FOR WASTE STORAGE}

The goal of radioactive-waste management is to isolate the waste from the biosphere until the radionuclides, through radioactive decay, no longer pose a hazard to man and his ecosystem. The length of time that different radioactive-waste materials must be isolated depends upon the type of waste and its level of radioactivity. The isolation period for certain low- and intermediate-level wastes ranges from less than 100 years to several thousand years; the isolation period for highlevel wastes may range from several thousand to several hundred thousand years. Circulating ground water is the natural mechanism by which radioactive material would most likely escape from a subsurface repository into the biosphere; thus, special attention must be given to the geologic and hydrologic characteristics of a region being considered for storage of radioactive waste (International Atomic Energy Agency, 1977).

Many anhydrite deposits have existed beneath the Earth's surface for millions of years without significant change, and substantial parts of these deposits apparently have remained free of circulating ground water. By studying individual anhydrite deposits, together with the hydrology, geologic structure, and general geologic framework of the particular anhydrite-bearing basin, we can determine the geologic processes that have affected the region in the past and can forecast, in general terms, the future impact of such processes on a repository site in that basin.

Because of the complexity of geologic processes, each repository site must be considered to be unique. General characteristics of the geologic environment that govern the suitability of a particular rock unit for waste storage were discussed in a report by the International Atomic Energy Agency (1977). Johnson and Gonzales
(1978) later summarized the regional geologic characteristics relevant for storage of waste in salt deposits; much of their discussion is repeated here because it also generally applies to storage of waste in anhydrite deposits. The importance of these characteristics is discussed in the following paragraphs, and the specific characteristics for each of the anhydrite-bearing basins in the United States are discussed in subsequent sections of this report.

\section{Structure and Geologic Framework}

The regional geology and geologic history of an evaporite basin must be known to understand the pracesses that have acted on a potential repository site in the past and those that may affect containment of waste in the future. Regions that have been tectonically stable over the past tens to hundreds of millions of years are likely to remain stable, at least during the next several hundred thousand years. Areas of anticipated rapid uplift or strong structural deformation are less desirable for waste storage, because either uplift and concomitant denudation of the host rock or structural disruption and distortion might release radionuclides into the biosphere. Some of the more important structural elements that should be studied for each deposit include the following.

\section{Dip or Inclination of Strata}

The generally preferred dip of strata in bedded anhydrite deposits is less than a few degrees, as this dip would enable nearly horizontal underground workings to be designed in the same rock layers over large areas. Steep dips, or tight folds that have frequent reversals in dip, also indicate that the rocks were subjected to deformation or tectonic stresses that may have produced complex geologic structures and the stresses may still be active.

\section{Faults and Joints}

Faults and joints generally are not desirable in rocks that might be used for containment of waste. The self-healing plastic behavior of salt and shale, which commonly are interbedded with anhydrite, would probably close the fractures in these rock types. Fractures in anhydrite and interbedded carbonates might not be sealed as readily, however, because of the more brittle nature of the rocks, and therefore might be pathways for circulating ground water. Faults and joints also might cause physical discontinuities in the host rock that could adversely affect mining operations. A region 
that contains only a few faults or joints might be suitable for waste storage if these structural features are located and then either avoided or considered in the planning of the excavations for a repository.

\section{Nature and Extent of Adjacent Strata}

Thick beds of shale, salt, or other plastic-behaving rocks that have low permeability not only would help to protect the anhydrite from circulating ground water but also would tend to deform without fracturing if the repository area were subsequently disturbed. The least desirable adjacent strata would be those that contain large quantities of circulating ground water that might enter the repository and eventually exit contaminated with radionuclides.

\section{Anhydrite Deposits}

The geometry, thickness, depth, and stability of the host rock for a radioactive-waste repository are critical considerations to long-term containment of radionuclides. Bedded anhydrite deposits have persisted tens of millions to hundreds of millions of years at the same location and, with the exception of the hydrationdehydration history of each gypsum-anhydrite deposit, generally have remained in the form as originally deposited. The very existence of these anhydrite deposits, which are at least moderately soluble in water, indicates that they have not been disturbed appreciably by circulating ground water. In some areas, anhydrite has flowed plastically in the geologic past, chiefly in response to flowage of associated salt deposits, to form diapiric cap-rock structures that consist of enormous, massive sulfate bodies. The anhydrite cap rock formed on some of the salt domes and salt anticlines, however, appears to have been stable for appreciable periods of geologic time since the end of diapiric movement.

\section{Depth of Storage Zone}

A repository should be deep enough below the land surface to ensure that contained waste will not be exposed to the biosphere through erosion or denudation during the period that the waste is hazardous. To negate the slow removal of the land surface through erosion, which generally proceeds at an average rate of $2.5-7.5 \mathrm{~m}$ per 100,000 years in the continental United States (Ritter, 1967), and to avoid the circulation of shallow ground water that might dissolve soluble rock or that might breach the repository, the waste should be stored at least $300 \mathrm{~m}$ beneath the surface. The rate of plastic flow of anhydrite that results from lithostatic pressure increases with depth; therefore, it probably is prudent to restrict mining operations in anhydrite to depths less than 1,500 $m$. Thus, the most feasible depth range for a repository in anhydrite extends from 300-1,500 m beneath the land surface. In this report, anhydrite deposits within that depth range are referred to as being at "moderate" depths, those at lesser depths as being "shallow," and those at greater depths as being "deep."

\section{Thickness and Extent}

In general, a repository host rock must be sufficiently large to permit fractures that emanate from the immediate surroundings of the repository to dissipate and terminate without jeopardizing the containment characteristics of the host rock. The host rock also must be thick enough to provide for adequate heat dissipation. A single bed of anhydrite at least $30 \mathrm{~m}$ thick is believed to be adequate to provide the necessary containment for mine workings. Strata reported to be at least $25 \mathrm{~m}$ thick also have been seriously considered in this report because they might locally thicken to as much as $30 \mathrm{~m}$ or more.

\section{Homogeneity}

In general, a high degree of homogeneity or consistency is desirable in rock units that are considered for storage of radioactive wastes. Laminated and nodular anhydrites (the most common types of anhydrite in natural deposits) contain impurities (chiefly carbonate and clay minerals); but if the impurities are uniformly distributed, the rock may behave as a homogeneous unit and its overall characteristics will tend to be more uniform. Layers or irregular masses of other materials within anhydrite can adversely affect mining operations if they are encountered during repository construction. Heat dissipation also may be adversely affected if large quantities of certain impurities lie near the disposal zone.

One of the major problems in compiling this inventory was determining the relative purity of anhydrite beds on the basis of published reports. For example, the Picacho basin in Arizona is described as containing “*** slightly more than $1,800 \mathrm{~m}$ of massive anhydrite containing only minor interbeds of shale, tuff, halite, and limestone nodules" (Eberly and Stanley, 1978 p. 931). However, the lithologic and mechanical logs of the one deep test in that basin show that the degree of interbedding is considerable and that few anhydrite beds approach or exceed $30 \mathrm{~m}$ in thickness. Bcds of anhydrite usually are described in the literature only in general terms, such as "relatively pure" or "massive." In terms of composition, these beds may indeed contain 90 percent or more calcium sulfate, which is "relatively pure" by most geologic standards. When examined in detail, 
however, all beds of anhydrite contain several different levels of impurities. Chemical impurities may occur within the anhydrite crystals, but this is not a common problem because most naturally occurring compounds of calcium sulfate (usually anhydrite or gypsum) that are found in major evaporite deposits are still regarded as chemically pure. For example, anhydrite (or gypsum) crystals commonly contain lower levels of impurities than does reagent-grade calcium sulfate.

Most lithologic units of anhydrite, including those described as "relatively pure" or "massive," contain impurities in the form of other lithologies such as shale, limestone, dolomite, and (or) halite. These lithologies may be present as interbeds (on a scale of centimeters to meters), interlaminations (on a scale of millimeters), matrix (nodular and mosaic anhydrite), or mixed crystals.

The relationships of impurities to the anhydrite produce structures and textures that have been given various terms in the literature. In an attempt to sort out the complications of textural terms, Maiklem and others (1969) proposed a classification of anhydrite based on textures and structures. In discussing the geologic characteristics of specific anhydrite deposits and of individual beds within deposits, we refer to this classification where information is available. Principally, we want to determine if the anhydrite within a bed is (1) bedded (and on what scale), (2) mosaic, (3) nodular (which implies anhydrite separated by matrix, and therefore a high matrix-to-anhydrite ratio and large amounts of impurities), or (4) massive and has no apparent structures (rare).

The most common forms of anhydrite are nodular and mosaic, which have been referred to by different authors as "nodular anhydrite," "chicken-wire anhydrite," or "mosaic anhydrite." These anhydrite units may vary considerably in amounts of impurities and in physical appearance. Where possible, we have included illustrations of anhydrite, but photographs of anhydrite have not been published for most deposits.

\section{Dissolution}

Because anhydrite is a moderately soluble rock, circulating ground water is one of the major threats to containment of radioactive waste in anhydrite beds. Anhydrite is about two orders of magnitude less soluble than is rock salt, but anhydrite dissolution and (or) hydration to gypsum still are important considerations in evaluating anhydrite as a potential repository host rock. Four requirements must be met for the dissolution of anhydrite: (1) a supply of water unsaturated with respect to calcium sulfate, (2) a deposit of anhydrite through which or against which the water flows, (3) an outlet to permit water that is rich in calcium sulfate to leave the anhydrite, and (4) energy (such as a hydrostatic head) to cause the water to flow through the system. An anhydrite bed at rather shallow depth may be in contact with circulating ground water along its upper surface and, to a lesser extent, along its base; thus, disposal zones should be sufficiently deep and distant from those areas where dissolution may occur. The natural protection of anhydrite from circulating ground water for long spans of geologic time is attested by the fact that anhydrite and associated salt beds of Cretaceous age and older generally have remained intact and undissolved beneath overlying sediments in thousands of square kilometers of such major basins as the Michigan, Appalachian, Gulf Coast, Permian, Williston, and Paradox. Evaporites in these basins, and those of other basins as well, have survived for more than 100 million years, a time span well beyond that of the hazardous period during which radionuclides must be isolated from the biosphere.

\section{Hydrology}

Special attention must be given to the hydrology of a prospective waste-storage area because of the extreme importance of understanding the circulation of water around or near a repository. A comprehensive geohydrologic study of the entire region or basin should include the following: establish spatial relationships, interconnections, and the direction, velocity, and volume of flow in all aquifers above and below the repository unit; identify recharge and discharge sites; and determine if anhydrite has been or is being dissolved, or is being hydrated to gypsum, as well as the potential for such processes to occur in the future.

\section{Surface Water}

The mere presence of surface streams, lakes, and ponds above an otherwise suitable repository site should not necessarily rule out its use, but a determination must be made that this water would not interfere with the short-term operation of a disposal facility or compromise the long-term containment of any emplaced wastes. Rock units beneath flood plains or other areas prone to flooding would be especially difficult to develop as a repository, because extreme conditions could lead to the flow of water into underground excavations through open shafts or boreholes unless special design features were implemented. Surface streams may undergo marked changes in their flow regimes over long periods of time, and thus such future behavior as the rate of incision and shifting of the streambed must be predicted to guard against breaching of the repository by erosional processes. 


\section{Ground Water}

The repository must be free of circulating ground water, which represents the main threat to containment of radioactive waste. Thus, the nature and characteristics of water-bearing strata near a potential host rock are critical elements in establishing the suitability of a proposed repository. Investigations also are needed to fully ascertain the nature and characteristics of the ground water itself. In many areas, ground water is an important resource for municipalities, industry, and agriculture, and care must obviously be taken to protect these water resources.

\section{Mineral Resources}

Nonanhydrite mineral resources, such as petroleum, salt, potash, gypsum, and sulfur, may be present near an anhydrite deposit being considered as a waste repository. These minerals can be present in formations that overlie or underlie the anhydrite unit, or they can be interbedded with the anhydrite in some deposits; therefore, the consequences of future activities aimed at seeking and extracting mineral resources should be considered. In areas of past mineral exploration or extraction, all preexisting boreholes, mine shafts, solution cavities, and other manmade excavations that penetrate the anhydrite zone in the vicinity of a proposed repository represent potential migration paths for ground water, and must be plugged and sealed effectively. The area should have little or no potential for future mineral exploration at depths that would affect the integrity of the deposit.

Anhydrite production in the United States now is rather small; most of the stone is used as a retarder in portland cement. Gypsum, on the other hand, is a major mineral commodity in the construction industry, and it is used chiefly in making wallboard, plasters, and special cements. Both anhydrite and gypsum are potential sources of sulfur, if the cost of extracting sulfur from these rocks becomes competitive with current methods of sulfur production. However, owing to the great abundance and widespread distribution of domestic anhydrite resources, no adverse impact on the future supply of this commodity is expected, even if radioactive wastes were stored in anhydrite at several sites.

\section{ORIGIN OF EVAPORITE DEPOSITS}

Evaporites are deposits of sediments or sedimentary rocks that are composed predominantly of minerals precipitated from brines that have been concentrated by evaporation. The classic theory for the origin of thick evaporite deposits is that they form on the floor of a standing body of water that has a restricted connection with the open sea. The restricted body of water may be on the scale of a deep ocean basin such as the Mediterranean Sea or, more commonly, an embayment, lagoon, or estuary. The restricted- or barred-basin theory was first proposed by Ochsenius (1877) and was later modified and applied to explain the origin of thick evaporite sequences by a number of investigators, most notably Adams (1944), King (1947), Scruton (1953), Dellwig (1955), Briggs (1958), Wardlaw and Schwerdtner (1966), Hite (1968), Dellwig and Evans (1969), Peterson and Hite (1969), Schmalz (1969), Raup (1970), Anderson and others (1972), and Dean and Anderson (1978). Examples of modern restricted environments that embody many of the features of the classic barred evaporite basin include the Gulf of Kara-Bogaz on the Caspian Sea (Dzens-Litovskiy and Vasil'yev, 1962), the Bocana de Virrila on the Peruvian coast (Morris and Dickey, 1957), and the northern part of Great Salt Lake, Utah, when it was largely cut off from the main part of the lake by a railroad causeway in 1959 (Madison, 1970; Whelan, 1972).

The classic theory for the origin of evaporite deposits was modified in the mid-1960's when thick evaporite deposits that formed in arid supratidal flats, or "sabkhas," were discovered along the Trucial Coast of Arabia, adjacent to normal marine waters of the Persian Gulf, and when data on this origin were synthesized into the so-called sabkha model of evaporite accumulation and diagenesis (Kinsman, 1966; Shearman, 1966; Butler, 1969).

When the sabkha model was formulated, researchers began to recognize a number of features in ancient evaporites, particularly in those dominated by gypsum and anhydrite, that had modern analogs in sabkha evaporites. Of particular importance to this study is the fact that anhydrite, which is locally abundant in the sabkha sediments of the Trucial Coast, characteristically occurs as nodular masses closely resembling nodular or mosaic structures-probably the most common form of ancient anhydrite. Many evaporite researchers assume that the presence of nodular anhydrite in an ancient evaporite deposit is indicative of a sabkha-like origin, although such a universal interpretation has been questioned (Dean and others, 1975). Because the sabkha model provided a modern analog, which the deep-water interpretation lacked, widespread and mostly uncritical acceptance of the sabkha model tended to overemphasize the evidence that supported the subaerial origin of evaporites, especially the presence of nodular anhydrite. By the mid-1970's, however, researchers recognized that there are deep-water evaporites that were deposited below wave base; shallow-water evaporites that were deposited above wave base, but that contain no evidence 
of complete desiccation; and subaerial sabkha evaporites that formed in marginal marine environments that were dry most of the time. These environments commonly have similar features, such as laminated and nodular anhydrite (Dean and others, 1975).

A subaqueous environment appears more plausible for the accumulation of many ancient, thick evaporite deposits that consist of nearly monomineralic beds. Evaporation of water in a shallow-water or deepwater basin, which is separated from the open ocean by a sill or shelf, would produce brines of increasing concentration. Where the salinity of such a brine reaches about five times that of normal seawater, calcium sulfate would begin to precipitate. Anhydrite $\left(\mathrm{CaSO}_{4}\right)$ theoretically should be the most stable calcium-sulfate mineral to form under most salinity and temperature conditions that are expected in an evaporite basin. However, as discussed later in the section "Chemical Characteristics of Anhydrite," gypsum $\left(\mathrm{CaSO}_{4} \cdot 2 \mathrm{H}_{2} \mathrm{O}\right)$ is the mineral that generally forms in modern evaporite deposits and in laboratory experiments. The contradiction between theoretical and observed data on gypsum and anhydrite formation remains unresolved. If studies of calciumsulfate mineralogy were restricted to laboratory synthesis and to modern deposits, the contradiction would seem to be resolved. However, the reason that anhydrite is the dominant calcium-sulfate mineral in ancient evaporite deposits must be explained.

When the salinity of evaporating brine reaches about 10 times that of normal seawater, most of the calcium sulfate has been deposited and halite $(\mathrm{NaCl})$ starts to precipitate along with gypsum (or anhydrite). When the salinity of the brine is about 20 times that of normal seawater, polyhalite $\left(\mathrm{K}_{2} \mathrm{Ca}_{2} \mathrm{Mg}\left(\mathrm{SO}_{4}\right)_{4} \cdot 2 \mathrm{H}_{2} \mathrm{O}\right)$ or, at higher temperatures, glauberite $\left(\mathrm{Na}_{2} \mathrm{Ca}\left(\mathrm{SO}_{4}\right)_{2}\right)$ are the sulfate minerals being formed. Polyhalite precipitates together with halite until the brine is saturated with respect to magnesium-bearing sulfates that are free from calcium and potassium.

Theoretically, progressive isothermal evaporation of seawater generally should result in the precipitation of carbonates (calcite, dolomite, or both), calcium sulfate (gypsum or anhydrite), halite, potassium- and magnesium-bearing sulfates and chlorides, and finally potassium-free magnesium salts. In general, portions of this succession can be observed in many natural marine evaporite deposits. Most discrepancies between observed and theoretical evaporite deposits can be explained by one or a combination of the following three conditions: (1) complete evaporative concentration of seawater rarely occurs, and evaporation seldom progresses past the precipitation of halite; (2) equilibrium precipitation of evaporite minerals is the exception rather than the rule; and (3) diagenesis may severely alter primary mineral facies.
Condition 1 leads to the commonly observed early sulfate excess, which refers to the fact that in an evaporite deposit that is formed by complete evaporation of normal seawater, the ratio of $\mathrm{NaCl}$ to $\mathrm{CaSO}_{4}$ theoretically should be about 22:1 by volume. However, in most marine evaporite deposits, the $\mathrm{NaCl}$ to $\mathrm{CaSO}_{4}$ ratio is about 3:1, is commonly less than 1:1, and may be as low as $1: 100$ (that is, anhydrite largely predominates over halite). The common explanation for this deficiency of halite (or excess of anhydrite) is that evaporation in the basin was incomplete and the brines that contained most of the sodium, magnesium, and potassium were continually refluxed out of the basin. Postdepositional dissolution of halite also may produce an increase in anhydrite relative to halite.

Condition 2, which also may account for discrepancies between theoretical and observed evaporite successions, is one of disequilibrium. Metastable minerals are common chemical precipitates under conditions of low temperature and pressure; two of the bestdocumented examples are aragonite and gypsum. As mentioned earlier, gypsum is almost invariably the calcium-sulfate mineral observed to form where seawater is evaporated under natural or laboratory conditions, even when anhydrite theoretically should form. The main cause of disequilibrium in the formation of evaporite minerals probably is related to precipitation kinetics; that is, precipitation is too rapid for equilibrium to be attained. The kinetics of equilibrium reactions requires that precipitation must occur under conditions of slow precipitation to prevent supersaturation; such conditions, however, are not common in the formation of evaporite minerals.

Because the minerals in evaporite sequences are so soluble, one would expect postdepositional modifications to be widespread. Diagenetic alteration may be caused by percolation of solutions of differing composition through the evaporite strata, or it may be in response to temperature. The abundant polyhalite in many evaporite deposits is a good example. Polyhalite is the most common, late-formed (halite- or posthalite-associated) sulfate mineral in natural evaporite deposits; this should be expected by theory, but the quantities actually found greatly exceed the theoretical amount. The abundance of polyhalite commonly is explained as the result of diagenetic alteration of anhydrite by potassium- and magnesium-rich solutions, an interpretation that is supported by polyhalite formation in modern evaporite deposits (Holser, 1966). Diagenesis has had a profound effect on most, if not all, evaporite sequences. Although problems of disequilibrium reactions still exist, diagenesis perhaps can account for most of the details that explain the discrepancies between theoretical and observed evaporite sequences. 


\title{
SECTION 2. Distribution and Geologic Characteristics of Anhydrite Deposits in the United States
}

\author{
By KENNETH S. JOHNSON', SERGE GONZALES ${ }^{2}$, and WALTER E. DEAN
}

\section{Summary}

Anhydrite deposits are widely distributed in the United States and are known to exist in 32 of the 48 conterminous states (fig. 2.1). Some of the deposits are extensive, such as anhydrite beds of the Silurian Salina Group in the Michigan and Applachian basins, Jurassic

${ }^{1}$ Oklahoma Geological Survey, Norman, Oklahoma.

${ }^{2}$ Earth Resource Associates, Inc., Athens, Georgia and Cretaceous anhydrites of the Gulf Coast basin, and Permian anhydrites of the Permian basin. Deposits that contain some of the thickest anhydrite beds in the world include the Castile Formation in the Delaware basin part of the Permian basin and the unnamed Tertiary evaporites in the Picacho basin of southern Arizona. Most of the anhydrite deposits in the United States occur within or on the margins of major sedimentary basins (fig. 2.2) that received thick accumulations of sediment during periodic marine inundations of parts of the continent in the geologic past.

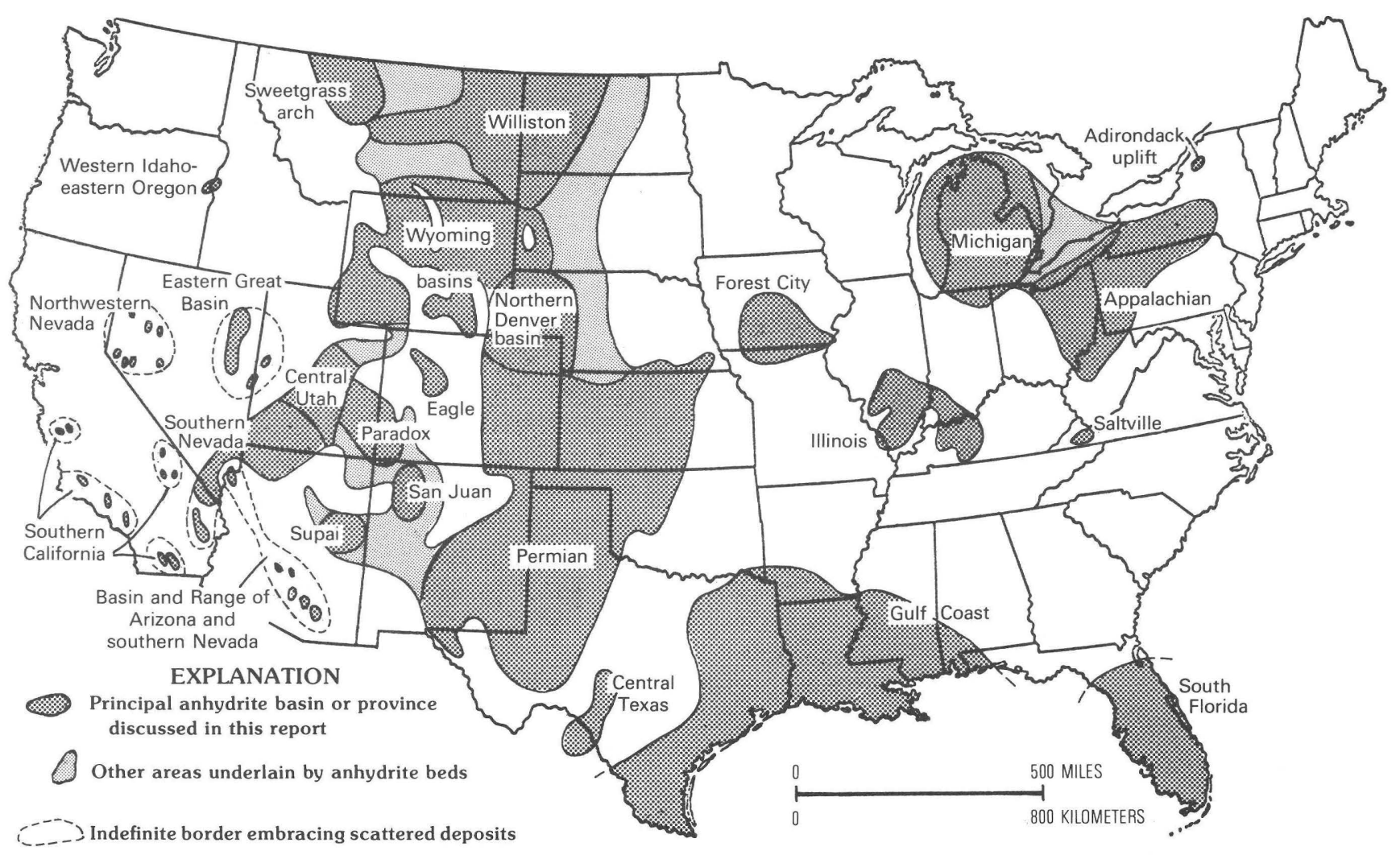

Figure 2.1. Anhydrite deposits in the conterminous United States (modified from Smith and others, 1973). 


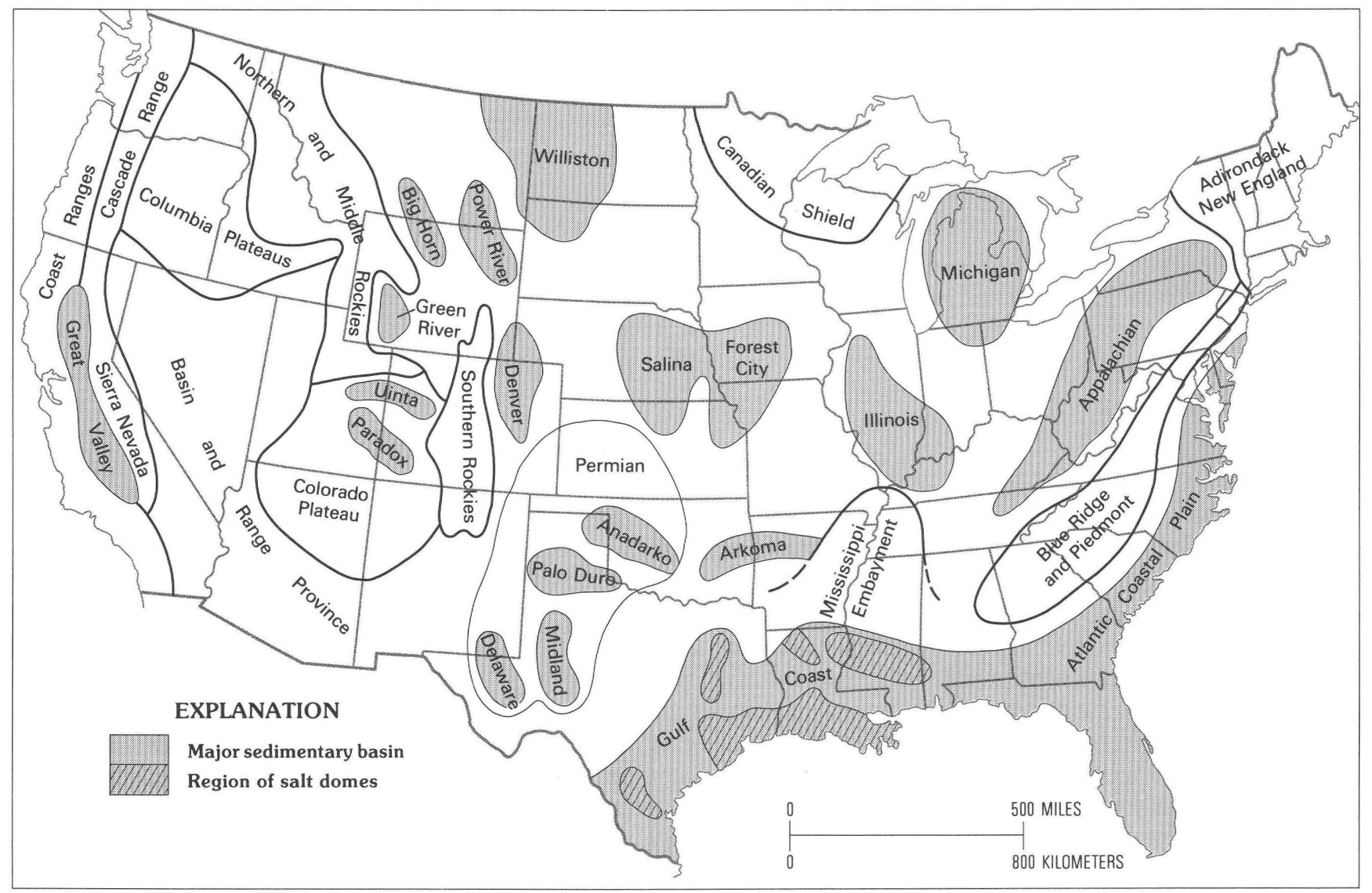

Figure 2.2 Major sedimentary basins and other principal tectonic features in the conterminous United States.

Anhydrite deposits in the United States cover a considerable span of geologic time and range in age from Precambrian to Tertiary. Geologic conditions favoring deposition of moderately thick to thick layers of anhydrite were repeated many times in various sedimentary basins. The oldest deposits are in the northern part of the country where Precambrian anhydrite occurs in the Adirondack Mountains and where Silurian anhydrite was deposited in the Michigan and Appalachian basins. The youngest deposits are in the Southwest where Tertiary anhydrite occurs in southern California and in the Basin and Range Province of Arizona and southern Nevada. The most numerous and widespread anhydrite deposits are those of Permian age, followed (in approximate order) by those of Jurassic, Mississippian, Triassic, Devonian, and Cretaceous age.

Twenty stratigraphic units contain anhydrite beds that are as much as $30 \mathrm{~m}$ thick and at moderate depths (fig. 2.3). The thickest beds are in the Castile Formation, which is as much as $600 \mathrm{~m}$ thick and contains anhydrite beds 30-105 $\mathrm{m}$ thick, and in an unnamed sequence in the Picacho basin, where anhydrite beds as much as $37 \mathrm{~m}$ thick occur in an 1,800-m-thick sequence that consists mainly of anhydrite. All units reported to contain anhydrite beds at least $30 \mathrm{~m}$ thick and at moderate depth are as follows: The A-2 anhydrite of the Salina Group in the Michigan Basin; G unit of the Salina Group in the Appalachian basin; cap rock on various salt domes, as 


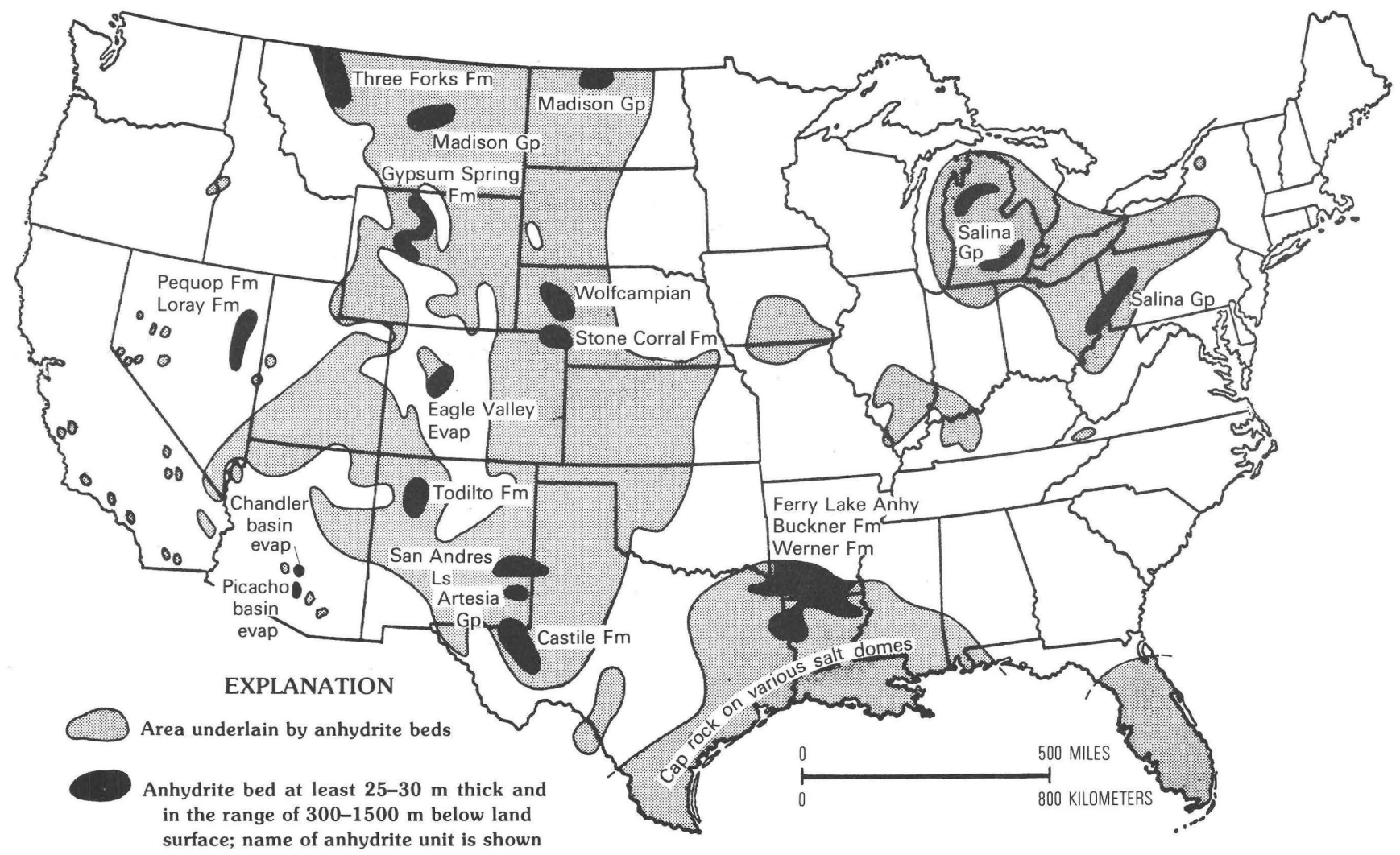

Figure 2.3 Areas in the conterminous United States where thick beds of anhydrite are present at moderate depths.

well as the Werner, Buckner, and Ferry Lake Formations in the Gulf Coast basin; Castile Formation, San Andres Limestone, and Artesia Group in the Permian basin; Wolfcampian strata and the Stone Corral Formation in the northern Denver basin; Gypsum Spring Formation in some of the Wyoming basins; Madison Group in two parts of the Williston basin; Three Forks Formation in the Sweetgrass Arch area; Eagle Valley Evaporite in the Eagle basin; Todilto Formation in the San Juan basin; unnamed anhydrite units in the Chandler and Picacho basins of Arizona; and the Pequop and Loray Formations of the eastern Great basin. In table 2.1 we have summarized data on the age, thickness, depth, and structural setting for these 20 units and all other anhydrite units discussed in this report.
The earliest major reports on gypsum and anhydrite distribution in the United States are those by Adams and others (1904) and Stone and others (1920). More recently, a comprehensive annotated bibliography of gypsum and anhydrite was prepared by Withington and Jaster (1960) and a nationwide mineral-resource map and bibliography were compiled by Withington (1962). A list of the anhydrite-bearing rock units of the United States was prepared by Smith and others (1973). In preparing this report we have also relied heavily upon the detailed studies of specific deposits published by the U.S. Geological Survey, the American Association of Petroleum Geologists, and various State geological surveys and geological societies. 


\begin{tabular}{|c|c|c|c|c|c|c|}
\hline Geologic province & Strat1graph1c un1t & $\begin{array}{l}\text { Geologic age } \\
\text { (E, Early; M, } \\
\text { Middle; L, Late) }\end{array}$ & $\begin{array}{l}\text { Thickness of } \\
\text { anhydrite beds } \\
\text { (meters) }\end{array}$ & $\begin{array}{l}\text { Depth to } \\
\text { anhydrite } \\
\text { (meters) }\end{array}$ & St ructure & Comments \\
\hline Michigan basin---- & $\begin{array}{l}\text { Salina Group---- } \\
\text { Lucas Formation of } \\
\text { Detroft River Group. } \\
\text { Michigan Formation--- }\end{array}$ & $\begin{array}{l}\text { L. Stlurian----- } \\
\text { M. Devonian----- } \\
\text { L. Mississippian- }\end{array}$ & $\begin{array}{l}\text { Commonly } 2-10 \\
\text { locally } 10-30 \\
2-15 \\
1-10\end{array}$ & $\begin{array}{l}150-1,800 \\
200-1,300 \\
30-350\end{array}$ & $\begin{array}{l}\text { Simple, with } \\
\text { gentle dips. } \\
\text { Simple- }\end{array}$ & $\begin{array}{l}\text { A-2 anhydrite is } 15-30 \text { an thick in small areas around } \\
\text { pinnacle reefs. } \\
\text { The formation contains interbeds of carbonates, salt, and } \\
\text { anhyrite. } \\
\text { Mined for gypsum around perimeter of basin. }\end{array}$ \\
\hline Appalachian basin--- & Sal1na Group - & L. Silurian---- & $1-37$ & $300-2,100$ & $\begin{array}{l}\text { Simple, with } \\
\text { gentie dips. }\end{array}$ & $\begin{array}{l}\text { Anhydrite beds in A, C, and F units commonly } 1-10 \text { m thick; } \\
\text { G-unit anhydrite is } 30-37 \text { in thick and } 1,500-2,100 \text { in deep. }\end{array}$ \\
\hline Ad1rondack up11ft--- & Grenville Complex-- & Precambrian---_-_- & As much as 60 . & $\begin{array}{l}\text { As much as } \\
\quad 800\end{array}$ & $\begin{array}{l}\text { Complex and } \\
\text { deformed. }\end{array}$ & $\begin{array}{l}\text { 01dest anhydrite reported in United States; metamorphosed } \\
\text { and wixed with other rocks in highly complex region. }\end{array}$ \\
\hline Saltville area-- & Maccrady Formation- & M1ss1ssipp1an--.-- & Lenses to 30 . & $\begin{array}{l}\text { As much as } \\
500\end{array}$ & $\begin{array}{l}\text { Complex and } \\
\text { deformed. }\end{array}$ & $\begin{array}{l}\text { Anhydrite occurs in irregular lenses and masses due to } \\
\text { deformation and flowage. }\end{array}$ \\
\hline I111no1s basin------ & St. Lou1s L1 mestone------ & L. M1ssissippian-- & $1-15$ & $100-1,000$ & S1mple---_-_- & $\begin{array}{l}\text { Anhydrite is lapure and irregularly interbedded with } \\
\text { limestone and dolomite. }\end{array}$ \\
\hline \multirow[t]{3}{*}{ Forest Clty basin--- } & $\begin{array}{l}\text { Wapsipinicon and } \\
\text { Cedar Valley Limestones. }\end{array}$ & Devonian--------- & \multirow{3}{*}{$\begin{array}{l}\text { Commonly } 2-5 \\
\text { locally as much } \\
\text { as } 30 . \\
\text { commoniy } 2-5 \\
\text { locally as much } \\
\text { as } 15 . \\
3-9\end{array}$} & $\begin{array}{l}\text { As much as } \\
300\end{array}$ & \multirow{3}{*}{ 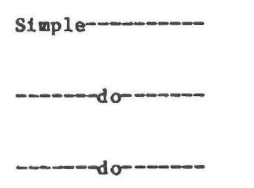 } & \multirow{3}{*}{$\begin{array}{l}\text { Where } 30 \text { m thick, unit is mostly anhydrite with interbeds } \\
\text { of } 11 \text { mestone. } \\
\text { Anhydrite irregularly interbedded with limestone. } \\
\text { Unit is gypsum and is mined extensively. }\end{array}$} \\
\hline & $\begin{array}{l}\text { Harsaw and St. Louis } \\
\text { Lifmestones. }\end{array}$ & MIssissippian---.-- & & $\begin{array}{l}\text { As much as } \\
300\end{array}$ & & \\
\hline & Fort Dodge Formation--- & Jurass1c---------- & & $5-20$ & & \\
\hline \multirow[t]{3}{*}{ South Florida basin- } & Fort P1erce Pormation--- & $\begin{array}{c}\text { Cretaceous(?) or-- } \\
\text { Jurassici? }\end{array}$ & - & 3,000 & S1mple-- & \multirow{3}{*}{$\begin{array}{l}\text { Unit is at great depth in basin. } \\
\text { Anhydrite beds probably no more than several meters thick } \\
\text { at depths less than } 1,500 \mathrm{~m} \text {; beds } 30 \text { a thick or thicker } \\
\text { are at depths of } 2,000-3,000 \text { mo } \\
\text { Anhydrite beds reportedly as much as } 25 \mathrm{~m} \text { thick. }\end{array}$} \\
\hline & $\begin{array}{l}\text { Punta Gorda, Sunniland, } \\
\text { Rattlesnake Hammock, and } \\
\text { Cordon Pass Formations. }\end{array}$ & E. Cretaceous & $\begin{array}{l}\text { Common1y } 3-10 \\
\text { locally } 30-50 .\end{array}$ & $1,500-3,000$ & 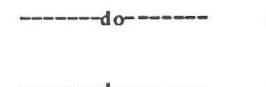 & \\
\hline & Cedar Keys Limestone-- & $\begin{array}{l}\text { E. Tert1ary } \\
\text { (Paleocene). }\end{array}$ & $10-25$ & $400-1,200$ & 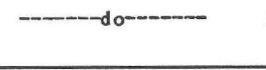 & \\
\hline \multirow[t]{4}{*}{ Gulf Coast basin--- } & Salt-dome cap rock---_- & $\begin{array}{l}\text { Cretaceous to } \\
\text { Ho 1ocene (source } \\
\text { beds are Jurass1c) }\end{array}$ & $25-240$ & $100-1,000$ & $\begin{array}{l}\text { Diapiric mass on } \\
\text { top of } \mathrm{salt} \text { domes, } \\
1-6 \mathrm{~km} \text { diameter. }\end{array}$ & \multirow{4}{*}{$\begin{array}{l}\text { Lithology of cap rock commonly is highly varlable; upper } \\
\text { part of cap rock commonly fractured, porous, and water } \\
\text { bearing; costal domes sti11 r1sing. } \\
\text { Un1t } 18 \text { 1,000-2,000 a deep in southern Arkansas. } \\
\text { Anyhydrite beds reportedly } 30-60 \text { m thick and } 1,000-1,500 \text { m } \\
\text { deep in southern Arkansas. } \\
\text { Thick anhydrite beds are } 300-1,500 \text { m deep in southern } \\
\text { Arkansas and northern Loulsiana. }\end{array}$} \\
\hline & Werner Formation- & M. Jurass1c--.-.- & $15-30$ & $1,000-3,000$ & $\begin{array}{l}\text { S1mple w1th } \\
\text { gentle dips. }\end{array}$ & \\
\hline & Buckner Pormation---_-_- & L. Jurass1c------ & Up to $30-60$. & $1,000-3,000$ & - gedo- & \\
\hline & Perry Lake Anhydr1te------ & E. Cretaceous--- & $3-30$ & $300-3,000$ & -_-_--do--_---- & \\
\hline Central Texas--_-_- & $\begin{array}{l}\text { Edwards L1mestone and } \\
\text { McKnight Format1on. }\end{array}$ & E. Cretaceous---- & $10-15$ & $300-2,500$ & Simple------_-- & $\begin{array}{l}\text { Edwards contains gypsum on outcrop; equivalent McKn1ght } \\
\text { contains anhydrite in Maverick basin. }\end{array}$ \\
\hline
\end{tabular}




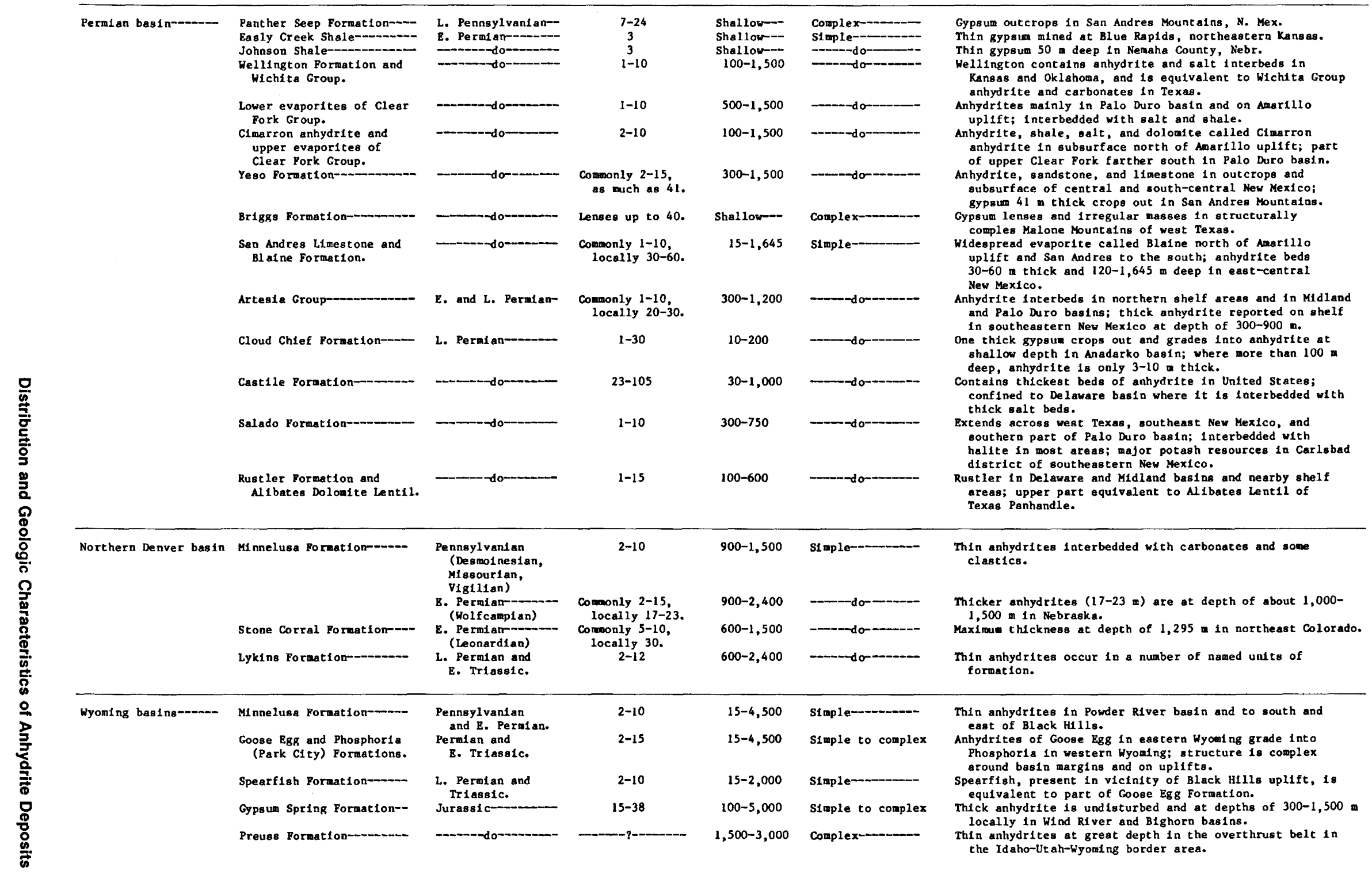


Table 2.1. Summary of geologic data on anhydrite deposits in the conterminous United States-Continued

\begin{tabular}{|c|c|c|c|c|c|c|}
\hline Williston basin--- & 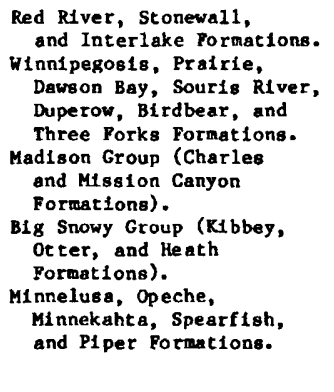 & 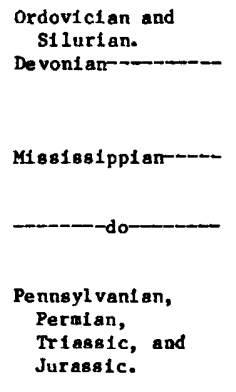 & $\begin{array}{l}1-6 \\
\text { Commonly } 2-10 \\
\text { locally } 15 \\
\text { Commonly } \\
\text { locally } 2-10 \\
2-10 \\
2-10\end{array}$ & $\begin{array}{l}2,400-4,000 \\
1,500-4,000 \\
1,000-3,000 \\
300-1,500 \\
1,200-2,000\end{array}$ & Simple to complex & 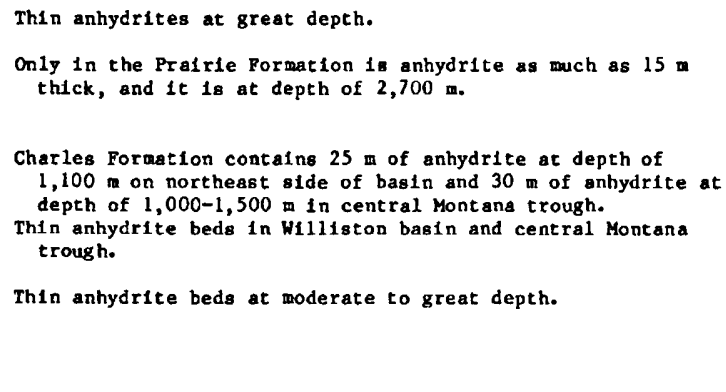 \\
\hline Sweetgrass arch----- & $\begin{array}{l}\text { Souris River and } \\
\text { Duperow Fornations. } \\
\text { Logan Gulch Member of } \\
\text { Three Porks Fornation. }\end{array}$ & L. Devonianm--n- & $\begin{array}{r}3-10 \\
12-30\end{array}$ & $\begin{array}{l}600-1,500 \\
600-1,500\end{array}$ & Simple--in-.- & $\begin{array}{l}\text { Thin anhydrite 1nterbedded with dolomite and some 11mestone. } \\
\text { Anhydrite beds } 12-30 \text { o thick over gentle arch and near } \\
\text { complex Rocky Mountain front to west. }\end{array}$ \\
\hline Eagle basin--- & Eagle Valley Evaporite-- & M. Penneylvanian- & $\begin{array}{l}\text { Comaonly } 5-30 \text {, } \\
\text { locally as much } \\
\text { as } 50 \text {. }\end{array}$ & $10-2,000$ & $\begin{array}{l}\text { Complex and } \\
\text { dIapiric. }\end{array}$ & $\begin{array}{l}\text { Thick beds of anhydrite and salt have flowed plastically } \\
\text { and form complex diapiric structures. }\end{array}$ \\
\hline Paradox basin----- & $\begin{array}{l}\text { Paradox Member of Mermosa } \\
\text { Formationo }\end{array}$ & M. Pennsylvanian-- & 3-10 & $200-2,000$ & Simple to complex & $\begin{array}{l}\text { The beds of anhydrite and thick beds of salt are flat- } \\
\text { lying at depths of } 500-2,000 \mathrm{~m} \text {, but have flowed plastically } \\
\text { to form complex diapiric structures in north part of the } \\
\text { basin. }\end{array}$ \\
\hline San Juan biesin----- & Todi1to Po rwation--- & M. Jurses1C- & $\begin{array}{l}\text { Comonly } 25-30 \\
\text { Iocally as mich } \\
\text { as } 40 \text {. }\end{array}$ & $100-2,700$ & $\begin{array}{l}\text { S1mple, with } \\
\text { gentie dips. }\end{array}$ & $\begin{array}{l}\text { Si ngle anhydrite bed in east half of basin; } 300-1,500 \text { deep } \\
\text { in southeast part of basin; about } 300 \text { m deep on Chama } \\
\text { platform in northeast part of basin. }\end{array}$ \\
\hline Supad salt basin-- & Supe1 Pormat1or-m & E. Permian- & $1-6$ & $180-750$ & s1mple--- & Thin anhydrite beds 1 nterbedded with red beds and halite. \\
\hline PIcacho basin- & Unnamed evaporites-.------ & $\begin{array}{l}\text { L. Tertiary } \\
\text { (M1ocene). }\end{array}$ & $\begin{array}{l}\text { Commonly } 2-10 \text { in } \\
\text { upper part, } \\
\text { commonly } 10-37 \\
\text { 1n lower part. } \\
\text { Commonly } 2-10 \\
\text { some } 20-106 \\
\quad 2-10\end{array}$ & $700-1,200$ & Simple--------- & $\begin{array}{l}\text { Th1ckest known anhydrite sequence in world, } 1,800 \mathrm{w} \text { thick; } \\
\text { consits of anhydrite (65 percent of totai), clastics, and } \\
\text { thin salt beds in nonmarine block-f aulted basin; many } \\
\text { anhydrite beds are } 10-37 \mathrm{~m} \text { thick. } \\
\text { Anhydrite sequence } 18500 \mathrm{~m} \text { thick and contains anhydrite } \\
\text { beds reported to be } 20-106 \text { in thick; nonmarine sediments } \\
\text { in block-fauted basin. } \\
\text { Thick nonmarine salt nass in block-faulted basin overla1n by }\end{array}$ \\
\hline Phoen1x basin--- & $\begin{array}{l}\text { Luke Salt Menber, Hickey } \\
\text { Forration. } \\
\text { Unnamed evaporites-- }\end{array}$ & 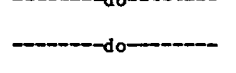 & ${ }^{2-10}$ & $\begin{array}{l}300-1,500 \\
900\end{array}$ & $\begin{array}{l}\text { Simple; possible } \\
\text { d1 apirism. } \\
\text { Simple--- }\end{array}$ & $\begin{array}{l}\text { Thick nonmarine salt aass in block-faulted basin overlatn by } \\
\text { several thin anhydrite beds. } \\
\text { Anhydrite sequence is } 150 \mathrm{~m} \text { thick, but thickness of } \\
\text { anhydrite beds not known. }\end{array}$ \\
\hline $\begin{array}{l}\text { Tucson basin--.-- } \\
\text { Virgin Valley basin- }\end{array}$ & Muddy Creek Pormation--- & 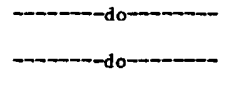 & $\begin{array}{l}3 \text { m and some } \\
\text { crystals. } \\
1-5(?)\end{array}$ & $\begin{array}{l}2,164 \\
200-800\end{array}$ & $\begin{array}{l}\text { Complex and } \\
\text { d1ap1ric. }\end{array}$ & $\begin{array}{l}\text { One thin anhydrite bed and gypsum crystals on edge of block- } \\
\text { faulted basin; middle of basin may contain more anhydrite. } \\
\text { Thek interbeds of halite, glauberite, and shale are locally } \\
\text { folded and faulted. }\end{array}$ \\
\hline
\end{tabular}




\begin{tabular}{|c|c|c|c|c|c|c|}
\hline $\begin{array}{l}\text { Southern Nevada and } \\
\text { nearby areas. }\end{array}$ & $\begin{array}{l}\text { Toroweap Formation- } \\
\text { Kaibab Formation- } \\
\text { Moenkopi Fornation-- } \\
\text { Chinle Pormation- } \\
\text { Carmel Pornation- } \\
\text { Curt1s Fordation-- } \\
\text { Horse Spring Formation- }\end{array}$ & 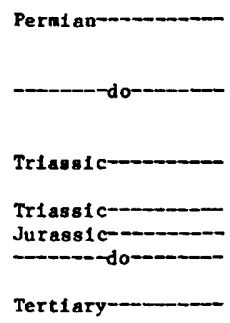 & 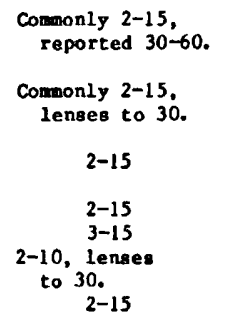 & 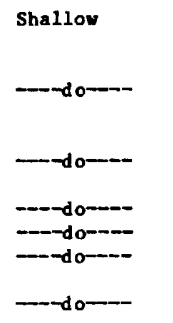 & 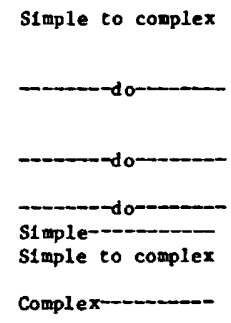 & 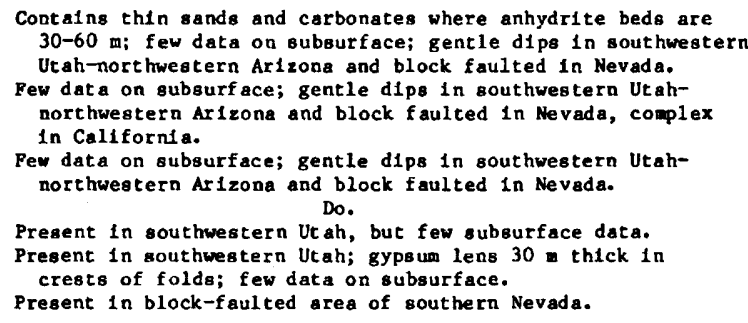 \\
\hline Central Utah- - & $\begin{array}{l}\text { Carmel, Arapien, and } \\
\text { Summerville Formations. } \\
\text { Flagstaff Lidmestone-- }\end{array}$ & $\begin{array}{l}\text { Jurassic-- } \\
\text { B. Tert1ery } \\
\text { (Paleocene and } \\
\text { (Eocene). }\end{array}$ & $\begin{array}{l}2-10, \text { lenses } \\
30-90 \text {. } \\
\text { As much as } 13 .\end{array}$ & $\begin{array}{r}15-3,600 \\
\text { Shallow-- }\end{array}$ & $\begin{array}{l}\text { Sinple to complex } \\
\text { Sinple-- }\end{array}$ & $\begin{array}{l}\text { Gentle dip of thin anhydrite beds in east; thick lenses in } \\
\text { dlapiric anticlines in west. } \\
\text { Thin gypsum of lacustrine origin; crops out and at shallow } \\
\text { depth. }\end{array}$ \\
\hline Bastern Great Basin- & Pequop and Loray Fornations & Peraien-_-_- & $\begin{array}{l}\text { Comanonly } 2-10 \\
\text { locally } 30-60\end{array}$ & $15-2,000$ & Conplex- & $\begin{array}{l}\text { Most data are on outcropping gypsun; gypsum beds } 30-60 \mathrm{~m} \\
\text { thick contain thin nonsulfate stratai four anhydrite beds, } \\
26-46 \text { m thick, reported at depths of } 457-1,403 \text { in } 1 \mathrm{n} \text { Nevada; } \\
\text { region } 1 \mathrm{~s} \text { block faulted. }\end{array}$ \\
\hline Northwestern Nevada- & Unoamed-_-_-_-_._- & $\begin{array}{l}\text { Triassic or } \\
\text { Jurassic. }\end{array}$ & $\begin{array}{l}\text { Lenses as much as } \\
30-60 \text {. }\end{array}$ & Wore than 20 & Conplex- - & $\begin{array}{l}\text { Strata are faulted, folded, and associated with netanorphic } \\
\text { rocks; thick lenses due to flowage. }\end{array}$ \\
\hline $\begin{array}{l}\text { Western Idaho and } \\
\text { eastern Oregon. }\end{array}$ & Unnamed-_.._-_-_._- & Tr1assic- & Lenses to 10. & Shallow--- & Complex- - & $\begin{array}{l}\text { Occurs as gypsum in 1rregular lenses as much as } 10 \text { a thick; } \\
\text { gypsum folded, faulted, as soclated with schist. }\end{array}$ \\
\hline Southern Callfornia- & Various units-- & $\begin{array}{l}\text { L. Tertiary } \\
\text { (M1ocene and } \\
\text { P1 locene). }\end{array}$ & $\begin{array}{l}\text { Commonly } 1-10, \\
\text { lenses as much } \\
\text { as } 30 \text {. }\end{array}$ & Sha1low--- & Complex- - & $\begin{array}{l}\text { Occurs as gypsum on scattered uplifted fault blocks; } \\
\text { deposits are folded, faulted, and steeply dipplag; thick } \\
\text { lenses slong crests of folds. }\end{array}$ \\
\hline
\end{tabular}




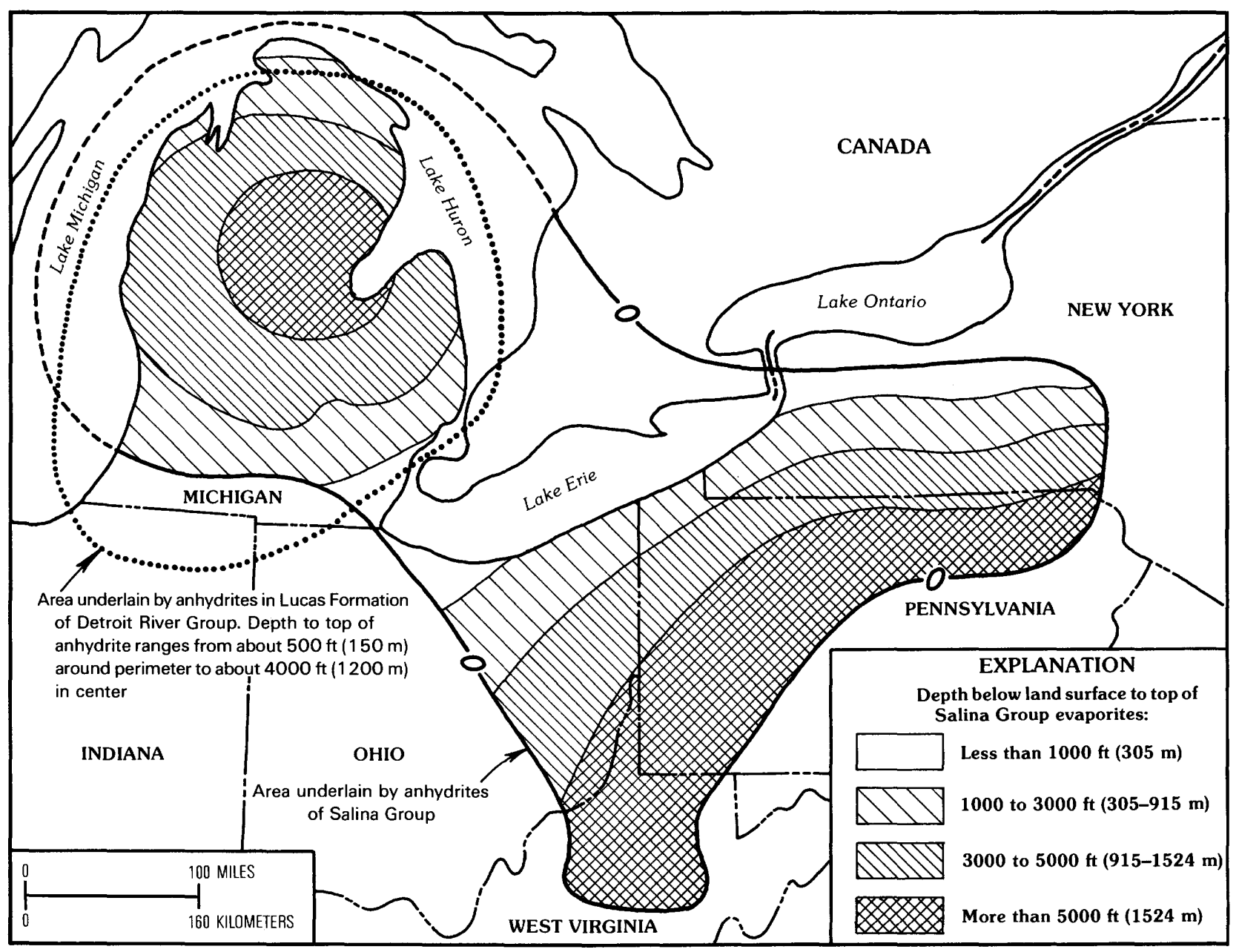

Figure 2.4. Distribution and depth below land surface of Silurian and Devonian evaporite deposits in the Michigan and Appalachian basins.

\section{MICHIGAN BASIN}

\section{Structure and Geologic Framework}

The Michigan basin is a major sedimentary and structural basin that encompasses all of Michigan's southern peninsula, as well as parts of Indiana, Ohio, and Ontario (fig. 2.4). It is bounded on the north and northeast by the Canadian shield, on the east and southeast by the Algonquin arch in Ontario and the Findlay arch in northern Ohio, on the southwest by the Kankakee arch in northern Indiana and northeastern Illinois, and on the west and northwest by the Wisconsin arch and Wisconsin dome.

Because the basin lies in the tectonically stable interior of North America it is characterized by essentially flat-lying sedimentary rocks that are folded or faulted at only a few places. Strata dip gently $\left(0.25^{\circ}\right.$ to $0.5^{\circ}$ ) into the center of the basin from the adjacent arches and shield area at a rate of 5-10 $\mathrm{m}$ per $\mathrm{km}$ (kilometer).

The deepest part of the basin underlies Clare and Gladwin Counties, in the central part of the southern peninsula of Michigan, where about $5,000 \mathrm{~m}$ of sedimentary rocks are believed to overlie the Precambrian (Ells, 1967). These sedimentary rocks include strata of Cambrian, Ordovician, Silurian, Devonian, Mississippian, Pennsylvanian, and Jurassic age. They are chiefly carbonates, shales, evaporites (salt and anhydrite), and sandstones (fig. 2.5). They are overlain at most places by Pleistocene glacial drift that averages between 60 and $90 \mathrm{~m}$ in thickness, but that is more than $275 \mathrm{~m}$ thick locally.

The basin may have first formed as an embayment as early as Cambrian time (Fisher, 1969). Throughout the remainder of the Paleozoic Era, the basin continued to subside more than the did adjacent regions, and thus it 

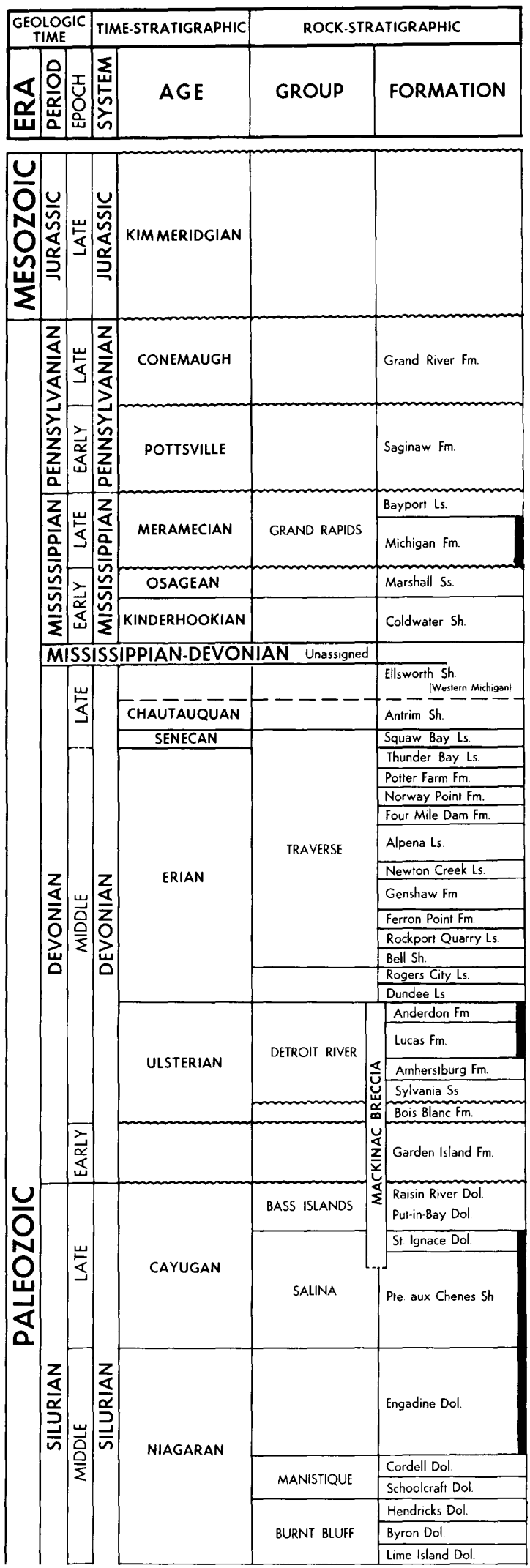

Figure 2.5. Stratigraphic succession in Michigan showing position of evaporite units as bars on right (modified from Michigan Geological Survey, 1964). received a great thickness of sediments in its central part. The major period of subsidence took place in Late Silurian time, which accounts in part for the deposition of the thick Salina salts in the Michigan basin.

Of principal interest for this report are the sedimentary rocks and the geologic history of the Silurian, Devonian, and Mississippian Periods, because these strata contain the evaporite deposits in the Michigan basin (fig. 2.6). The formal lithostratigraphic nomenclature assigned to the strata in the Michigan basin in this report is that used by the Michigan Geological Survey. The Salina Group of Silurian age, one of the greatest accumulations of salt anywhere in the world, contains a number of anhydrite interbeds; one has a maximum thickness of $30 \mathrm{~m}$. Anhydrite beds as much as $15 \mathrm{~m}$ thick are interbedded with salt and carbonates in the Devonian Detroit River Group, and anhydrite units as much as $10 \mathrm{~m}$ thick are present in the Mississippian Michigan Formation.

\section{Salina Group}

The Upper Silurian Salina Group is a thick sequence of evaporites, carbonates, and clastics underlying the Michigan basin and the northern part of the Appalachian basin to the east (fig. 2.5). This marineevaporite section, which consists mainly of rock salt, is about $800 \mathrm{~m}$ thick in the central part of the Michigan basin, and contains anhydrite beds that commonly are 2-10 $\mathrm{m}$ thick. Toward the margins of the basin, several of the anhydrite beds are thicker than $10 \mathrm{~m}$, and one of them is as much as $30 \mathrm{~m}$ thick. Among the large number of studies done on the Salina Group are the comprehensive reports of Landes (1945), Alling and Briggs (1961), Ells (1967), Briggs and Briggs (1974), Mesolella and others (1974), and Nurmi and Friedman (1977). Studies along the margins of the basin include those by Gill (1977), Huh and others (1977), and Budros and Briggs (1977). The potential use of salts in the Salina Group for radioactive waste disposal has been discussed by Briggs (1968), Landes (1972), and Johnson and Gonzales $(1976,1978)$.

Carbonates (limestone and dolomite) that formed during Early Silurian time represent deposition in shallow and warm marine waters. This carbonate deposition reached optimum conditions later during the Middle Silurian, when the Niagaran reef platform developed along the borders of the Michigan basin (Briggs and Briggs, 1974). The reef bank ranges in width from 8-30 km and separates a back-reef lagoonal zone outside the basin from a shelf area and the central-basin area enclosed by the reef. The shelf area, which is about 


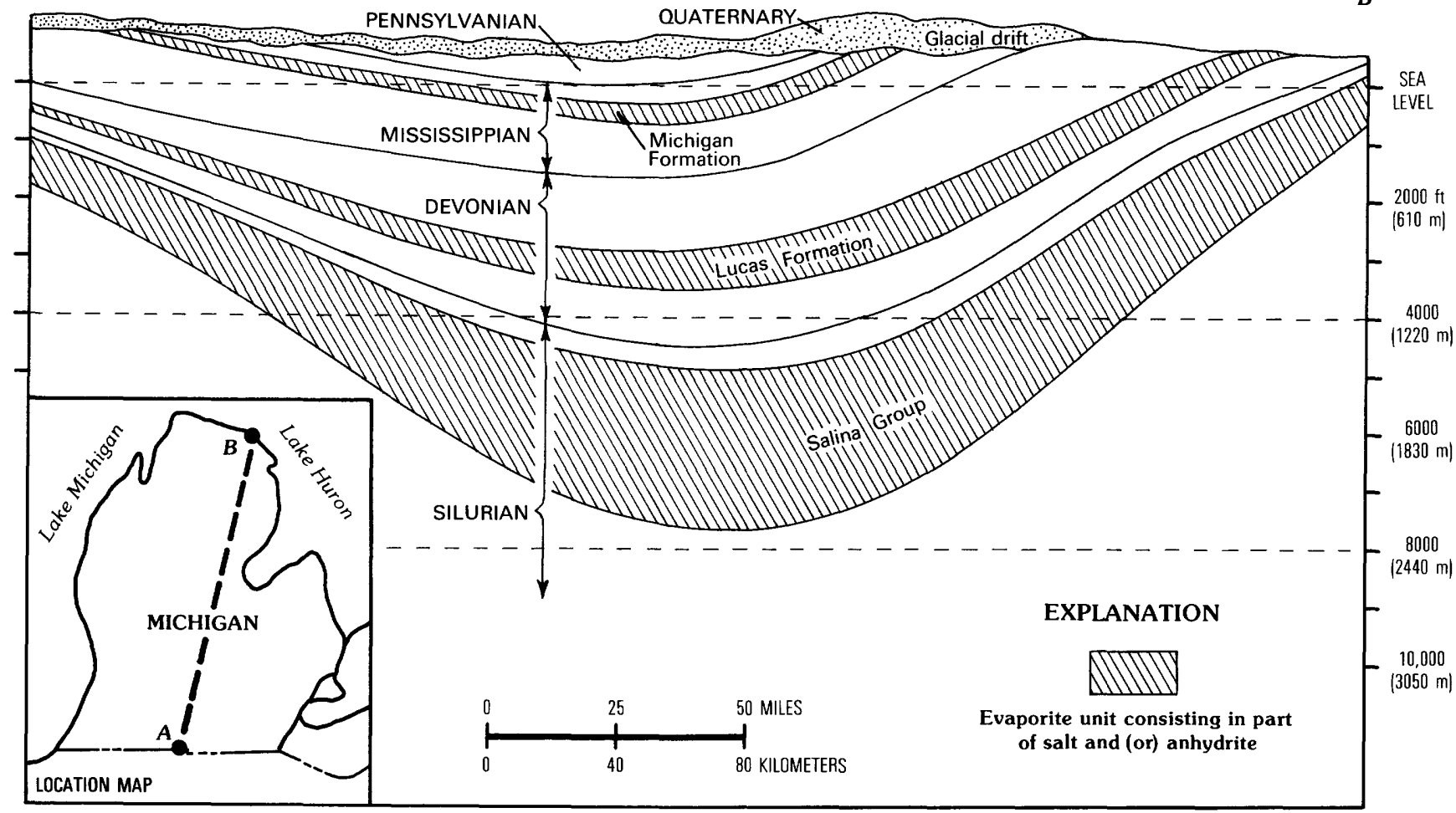

Figure 2.6. Generalized north-south cross section through the Michigan basin showing principal evaporite units (modified from Johnson and Gonzales, 1978).

$20-30 \mathrm{~km}$ wide in the north and 30-60 $\mathrm{km}$ wide in the south, was a favorable site for the growth of numerous pinnacle reefs, many of which are prolific oil and gas reservoirs.

The Salina evaporites were deposited after major growth of the Niagaran reefs ceased in the Michigan basin (Mantek, 1973; Briggs and Briggs, 1974). Marine regression led to restricted circulation of the waters in the Michigan basin, compared with those of the open ocean, and, as a result, the waters in the basin were evaporated until halite and anhydrite were deposited. Intermittent replenishment of marine water to the basin permitted deposition of thick evaporite sequences that extended throughout most of the southern peninsula of Michigan. During periods of marine transgression the basin was flooded, and carbonates and other normal marine sediments were deposited. Salina deposition therefore is characterized by a series of marine transgressions and regressions, and evaporites were formed during the regressions.

Total thickness of the Salina Group ranges from several hundred meters around the perimeter of the basin to about $800 \mathrm{~m}$ near the depocenter. The depth to the top of the upper, or $\mathrm{F}$ evaporite ranges from 150 to $300 \mathrm{~m}$ along the margins to more than $1,800 \mathrm{~m}$ in the center. Thickness of the evaporites decreases away from the middle of the basin chiefly due to depositional thinning, but also due in part to local dissolution of salt near the shallow edge of the basin.

The Salina Group consists of a number of informal stratigraphic units; most units are composed predominantly of salt, carbonates, or shales, and several units contain anhydrite interbeds. Individual units have a similar lithologic character over a wide geographic area, and the distinctive mechanical log curves for each unit permit reliable correlations over large distances (Ells, 1967). Landes (1945) established the basic subdivision of the group by recognizing units $A$ through $G$, from oldest to youngest, and this nomenclature has continued to be used throughout the Michigan basin.

The A-1 and A-2 evaporites, in the bottom part of the Salina, are typically massive salt units that are 60-120 $m$ thick in most of the basin (Mesolella and others, 1974). Both units commonly contain anhydrite beds $2-10 \mathrm{~m}$ thick at the base and (or) top of the salt within the basin, but the salt thins abruptly toward the basin margin and grades into moderately thick anhydrite near the Niagaran reef and some of the associated platform and back-reef areas. Anhydrite beds are more than $15 \mathrm{~m}$ thick locally along this narrow transition zone, and the A-2 anhydrite is a widespread bed about $10 \mathrm{~m}$ thick in the back-reef 


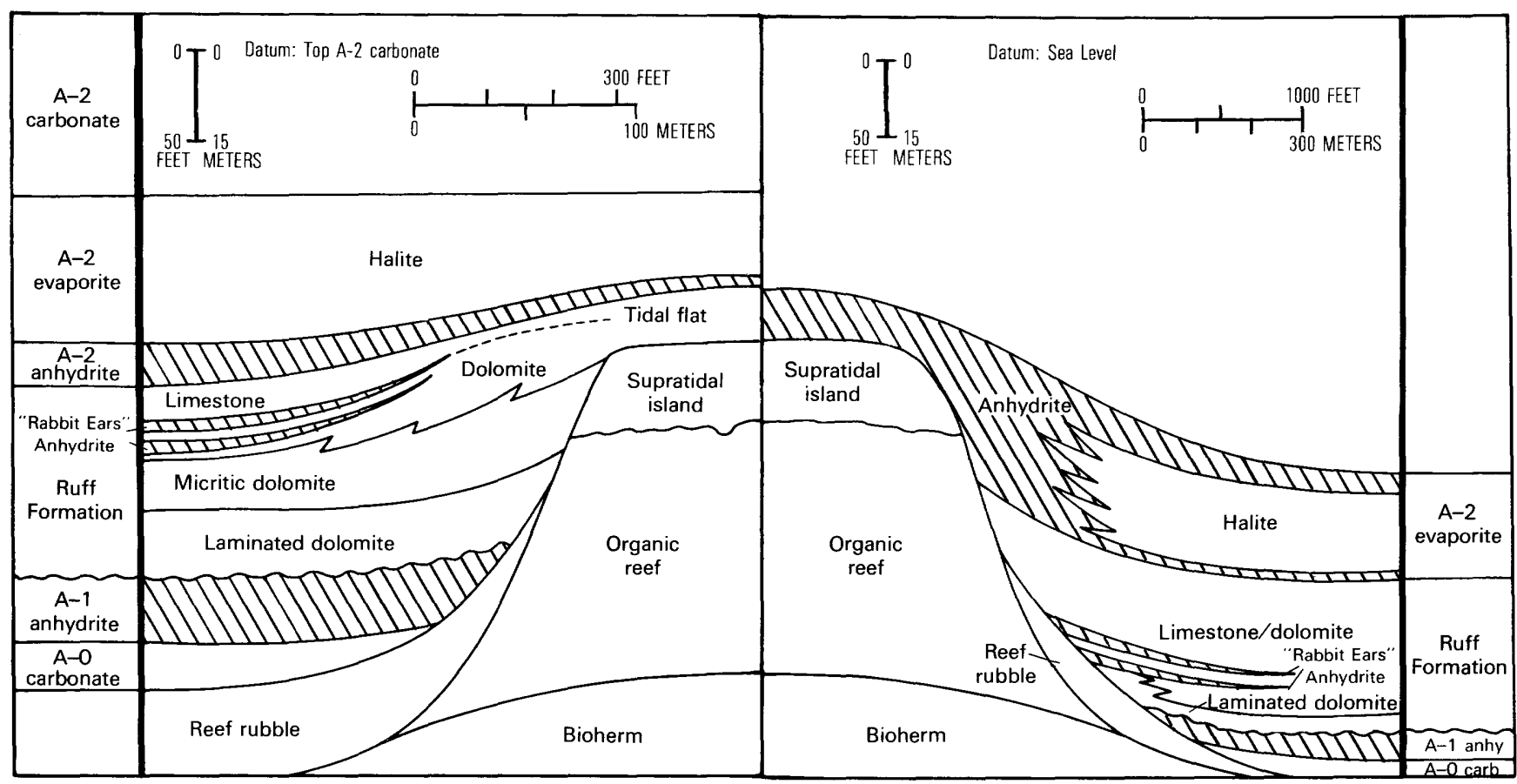

Figure 2.7. Distribution of anhydrite and other facies in vicinity of pinnacle reefs in northern and southeastern parts of Michigan basin (modified from Budros and Briggs, 1977).

area on the north side of the basin. The anhydrite beds consist mainly of laminated limestone and anhydrite and nodular mosaic anhydrite (Gill, 1977; Nurmi and Friedman, 1977).

Anhydrite beds also thicken abruptly in the vicinity of the small pinnacle reefs that typically are $100-1,000 \mathrm{~m}$ in diameter and that rise several hundred meters above the foreslope of the main reef bank (fig. 2.7). The A-1 anhydrite is locally as much as 9-12 m thick in a narrow band around the pinnacle reefs, but it pinches out at the edge of reefs. The A-2 anhydrite is locally $15-30 \mathrm{~m}$ thick where it thickens sharply on the flanks and over the top of some of the pinnacle reefs. Although these are the thickest beds of anhydrite in the Salina Group in the Michigan basin, the area of each occurrence is only a little larger than the pinnacle reef itself. In general, the pinnacle reefs in the southern part of the Michigan basin are larger than those in the northern part (and therefore the area of each thick anhydrite deposit is larger), and they occur at shallower depths (less than 1,200 m).

The younger $B$ and $F$ units are also thick evaporites that consist mainly of salt, but they usually contain interbeds of shale, dolomite, and anhydrite. Individual anhydrite beds in these units generally range from 2 to $10 \mathrm{~m}$ in thickness. The thick B salt unit is thinner toward the margin of the basin and grades into an anhydrite unit less than $15 \mathrm{~m}$ in thickness. The entire anhydritic $\mathrm{B}$ unit is more than $30 \mathrm{~m}$ thick in a small part of the northern
Michigan basin (Mesolella and others, 1974), but this unit actually consists of anhydrite interbedded with salt and other rock types. In the upper peninsula of Michigan, gypsum beds $2-6 \mathrm{~m}$ thick are present near the northern limit of the Salina Group, just below the surface near St. Ignace and on St. Martin Island (Smith and Stone, 1920).

\section{Lucas Formation of Detroit River Group}

The Lucas Formation, in the Middle Devonian Detroit River Group, is a thick sequence of carbonates and evaporites that underlies most of the Michigan basin (fig. 2.8). Rock salt is the principal evaporite in the Lucas Formation in the north-central part of the basin, but anhydrite occurs in beds $2-15 \mathrm{~m}$ thick in this area and elsewhere beyond the salt area. Several beds of anhydrite 2-10 m thick are also present in the Dundee Limestone above the Detroit River Group. Comprehensive regional studies of the Lucas Formation and other formations in the Detroit River Group were made by Landes (1951), Briggs (1959), Ehman (1964), and Gardner (1974); and additional localized studies were done by Sloss (1953), Fugate (1968), Sutton (1968), Wirth (1968), Rooney and French (1968), and Matthews (1977). Gypsum resources and anhydrite in the Detroit River Group were reported by French and Rooney (1969) and Briggs (1970). 


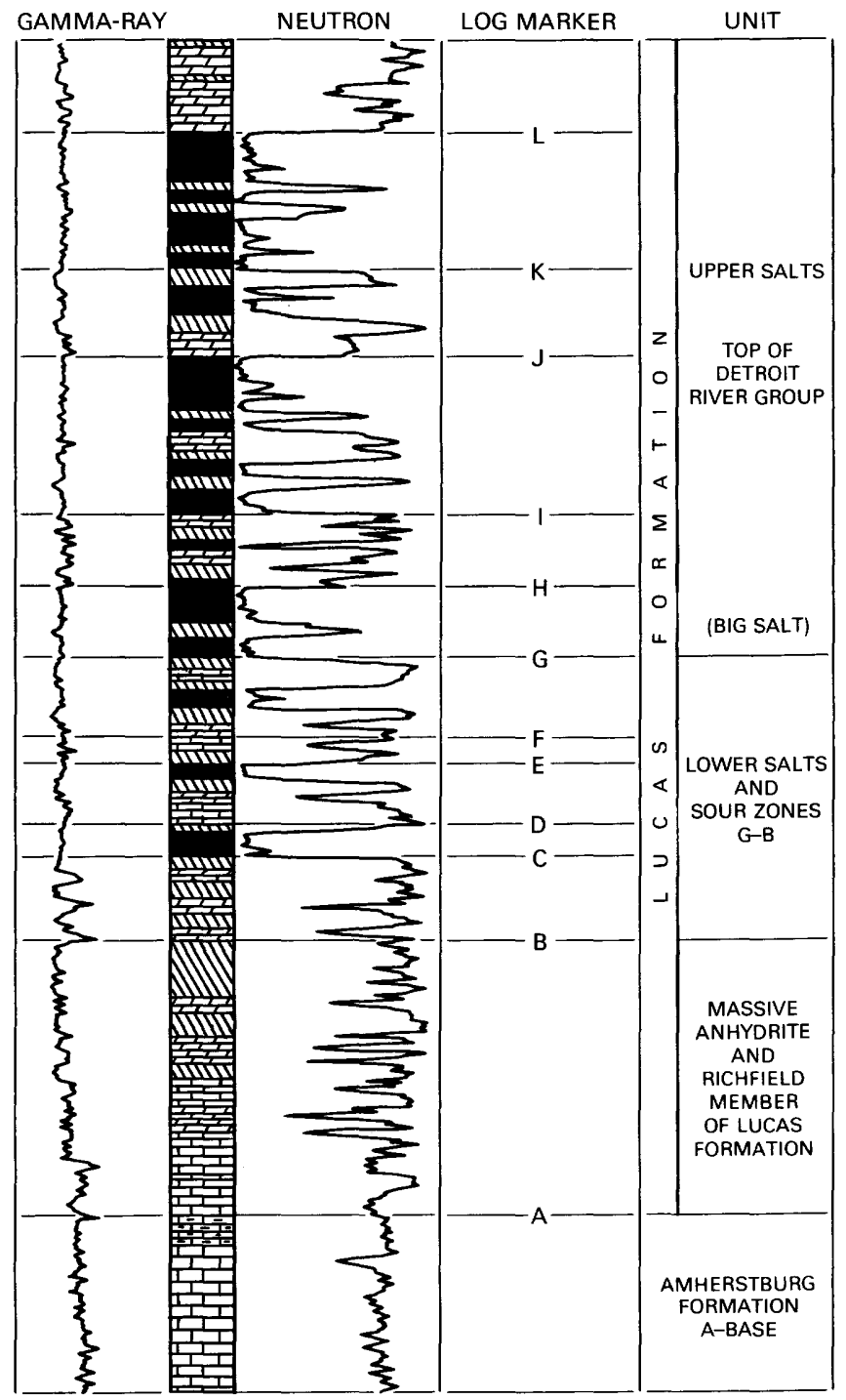

\section{EXPLANATION}

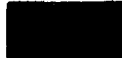

Salt

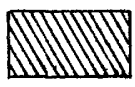

Anhydrite
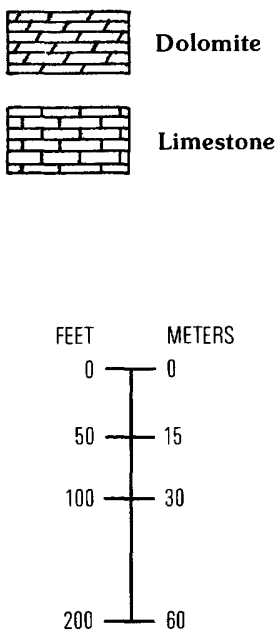

Figure 2.8. Stratigraphic sequence of part of the Detroit River Group in the Michigan basin (modified from Briggs, 1970).

Most of northern Indiana and Ohio and the southern peninsula of Michigan are underlain by evaporites in the Lucas Formation. The total thickness of the formation ranges from about $100 \mathrm{~m}$ around the perimeter of the Michigan basin to about $400 \mathrm{~m}$ in the north-central part of the basin in parts of Roscommon, Missaukee, and Clare Counties, Mich. (Gardner, 1974). Decrease in thickness toward the margins of the basin is due mainly to depositional thinning of salt beds. The depth to the top of the Lucas evaporites ranges from about $200-500 \mathrm{~m}$ around the perimeter of the basin to as much as $1,300 \mathrm{~m}$ in the center of the basin.

Rock salt is the dominant lithology in the Lucas Formation in the north-central part of the basin, and dolomite is dominant elsewhere. Anhydrite typically makes up less than 50 percent of the total thickness of the Lucas Formation in all parts of the Michigan basin, although some parts of the individual members may contain 50-75 percent anhydrite (Briggs, 1970; Gardner, 1974).

The lower division of the Lucas Formation is the Richfield Member (Landes, 1951), which is 30-60 m thick in the center of the basin and consists of interbedded dolomite and anhydrite. The thickness of anhydrite beds decreases rapidly outward from the center of the basin toward its margins on the west and north. Typical structures of anhydrite in the Richfield Member are shown in figures 2.9 and 2.10. Anhydrite begins at the

Figure 2.9 (facing page). Examples of nodular, pillar and massive anhydrite from the Richfield Member of the Lucas Formation (Middle Devonian) in the Michigan basin (from Gardner, 1974). 

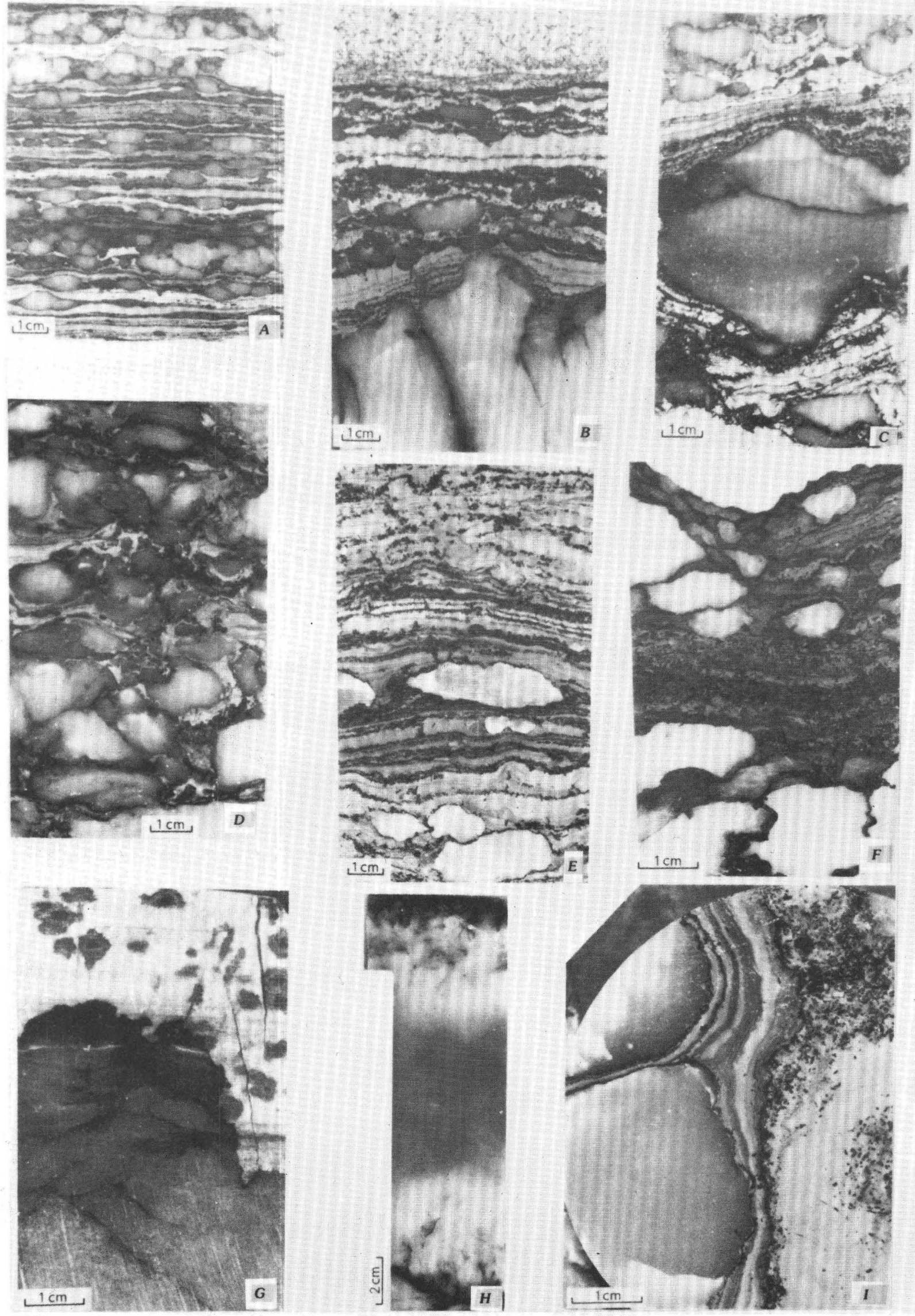

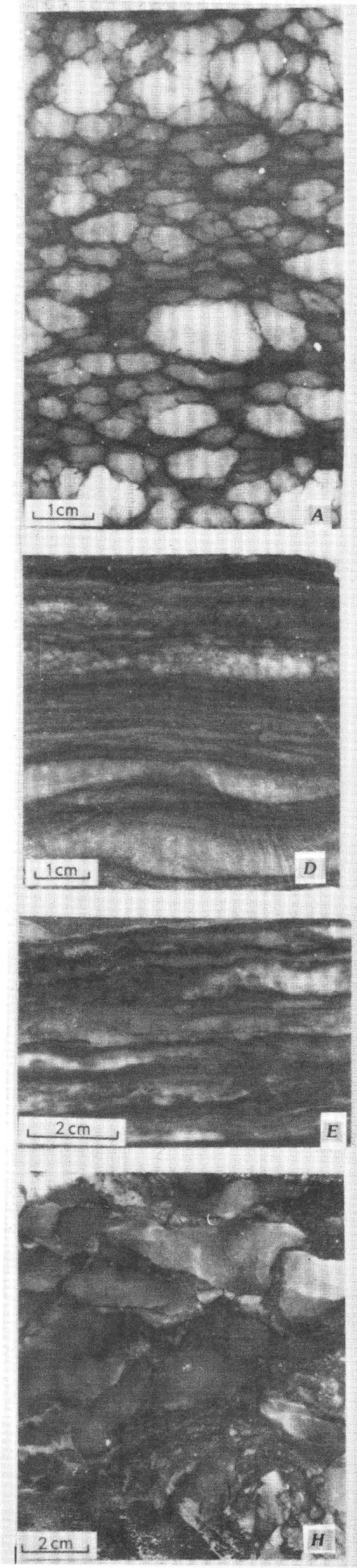
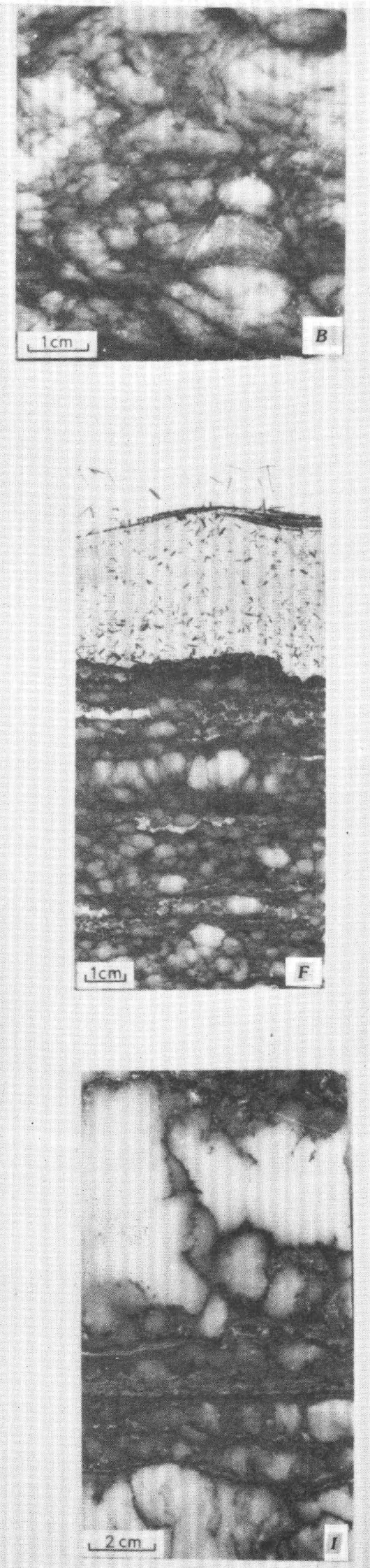
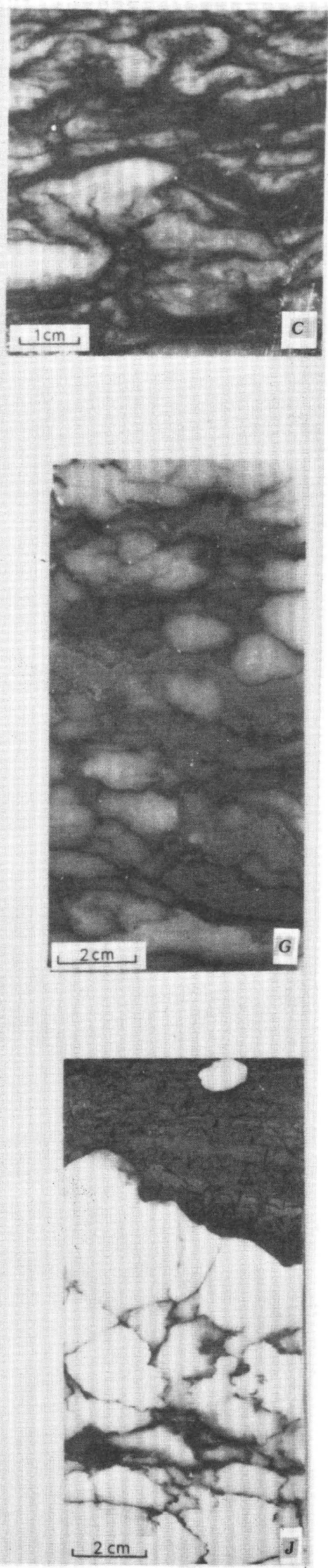
Figure 2.10. (facing page). Examples of reticulate, contorted, lamellar, and nodular anhydrite from the Lucas Formation $(A-C, E-J)$ and Dundee Limestone $(D)$, Michigan basin (from Gardner, 1974).

base of the Richfield Member as anhydrite laths in dolomite; it grades upward into discontinuous beds of nodular anhydrite (fig. 2.9, $A$ and $E$ ), and finally into more continuous beds of nodular anhydrite. The upper bed of anhydrite in the Richfield Member (the so-called "big anhydrite" or cycle 1 of Matthews, 1977) is an excellent, widespread stratigraphic marker bed. The Richfield Member is an important oil-producing unit in the Michigan basin; in 30 fields, it accounts for about 10 percent of Michigan's total production of hydrocarbons.

The Richfield Member of the Lucas Formation is overlain by the Iutzi Member (Gardner, 1974), which is $45-60 \mathrm{~m}$ thick in the center of the basin. Individual beds of anhydrite within the Iutzi are typically $2-10 \mathrm{~m}$ thick, and in places are as much as $15 \mathrm{~m}$ thick. These beds make excellent stratigraphic markers that are correlative across the basin. The thickest anhydritic unit in the Iutzi Member is the "massive anhydrite," which is $20-30 \mathrm{~m}$ thick over most of the basin where it is most massive. However, individual beds of anhydrite in this unit are no more than $15 \mathrm{~m}$ thick. All the anhydrite in the "massive anhydrite" unit is nodular.

Above the Detroit River Group is the Dundee Limestone, which contains several anhydrite beds 2-10 m thick in the west half of the Michigan basin (Gardner, 1974). Total thickness of the Dundee Limestone in this area is $30-75 \mathrm{~m}$, and the anhydrite is interbedded with dolomite and some limestone.

\section{Michigan Formation}

The Michigan Formation, of Late Mississippian age, consists of clastic sediments and evaporites in the central part of the Michigan basin (fig. 2.11). Included in the formation are gypsum deposits that are being mined at and near the outcrop in two districts and anhydrite that is in the deeper subsurface. Gypsum and anhydrite beds range in thickness from 1-10 m. Early studies of gypsum and anhydrite were done by Smith and Stone (1920) and Newcombe (1928), and later reports were published by Poindexter and others (1951) and Briggs (1970).

The Michigan Formation is about $60 \mathrm{~m}$ thick at the perimeter of the basin and as much as $120-150 \mathrm{~m}$ thick in the center. Gypsum beds crop out locally on the east and west sides of the Michigan basin, but the top of the formation is as much as $350 \mathrm{~m}$ below ground level in the center of the basin (Briggs, 1970).
The lithologies of the Michigan Formation consist of interbedded sandstone, shale, gypsum, and anhydrite. About 15 separate gypsum or anhydrite beds have been reported (Briggs, 1970), but each bed is only 1-10 m thick. The principal emphasis of most studies has been on the gypsum in the formation. The amount and distribution of anhydrite in the various calcium sulfate beds is not reported, although the beds are probably anhydrite in the deeper subsurface.

Mining of gypsum in Michigan is centered in the Grand Rapids-Grandville district in Kent County in the west and the Alabaster district in Iosco County in the east (Smith and Stone 1920; Newcombe, 1928). In Kent County, several beds 2-6 m thick are being quarried and mined at depths as much as $30 \mathrm{~m}$. In Iosco County, gypsum beds 5-7 $\mathrm{m}$ thick are being quarried from beneath thin deposits of glacial drift.

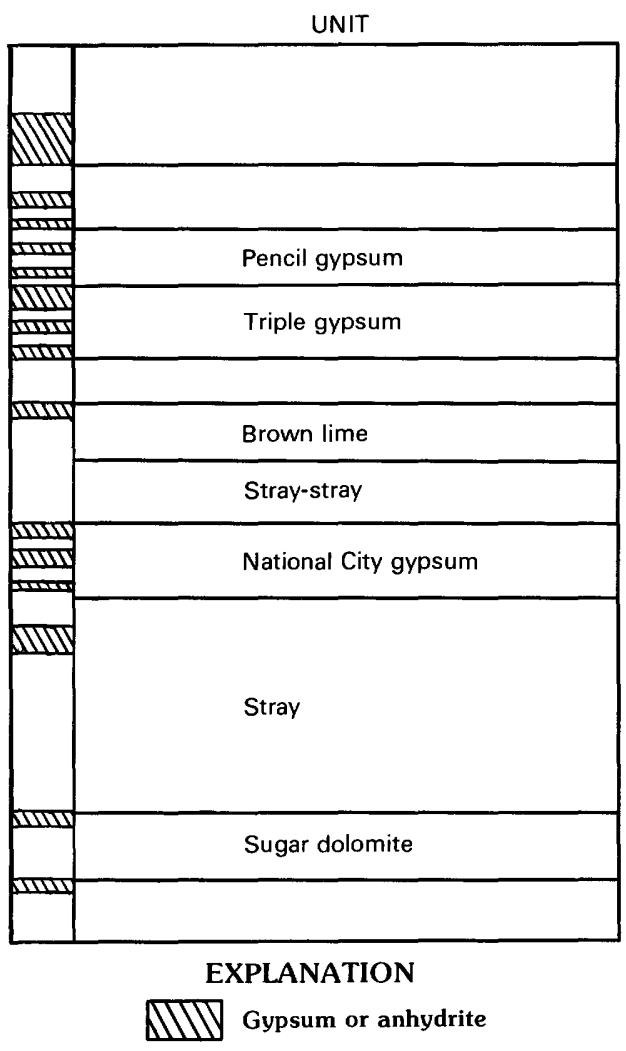

Figure 2.11. Stratigraphic sequence and gypsum deposits in the Mississippian Michigan Formation of the Michigan basin (modified from Briggs, 1970). Thickness not reported, but entire sequence probably no more than $150 \mathrm{~m}$ thick. 


\section{APPALACHIAN BASIN-SALINA GROUP}

The Late Silurian in the Appalachian basin of the Northeastern United States consists of a thick sequence of evaporites, carbonates, and shales that contain several anhydrite units. One of the anhydrite beds near the top of the Salina thickens into the deep basin, and reaches thicknesses of between 30 and $37 \mathrm{~m}$ at a depth of 1,500-2,100 m below the surface. Regional studies of the Salina Group evaporites in the Appalachian basin have been done by Alling and Briggs (1961), Ulteig (1964), Fergusson and Prather (1968), Rickard (1969), Clifford (1973), Heyman (1977), Smosna and others (1977), Smosna and Patchen (1978), and Mesolella (1978). The formal nomenclature of these workers is used in this report. Johnson and Gonzales (1978) also studied the salts in the Salina Group as potential host rocks for disposal of radioactive waste.

The Appalachian system, the dominant tectonic feature in the Eastern United States, consists of several structural belts that can be traced from northern Alabama through the New England States. Great thicknesses of Precambrian through Permian sedimentary rocks are present in the western part (Appalachian basin), and a large volume of metamorphic and igneous rocks occupy the eastern part (Blue Ridge and Piedmont provinces).

The undeformed part of the Appalachian basin being considered in this report is an elongated sedimentary and structural basin that extends northeastward from Tennessee across parts of Kentucky, Virginia, West Virginia, Ohio, Maryland, Pennsylvania, and New York (fig. 2.2). This regional feature is bordered on the west and north by the Cincinnati, Findlay, and Algonquin arches and the Adirondack uplift, and on the east by the tightly folded and faulted Valley and Ridge province. The basin contains a southeastward-thickening prism of sandstones, limestones, dolomites, shales, and evaporites that total $2,000-7,000 \mathrm{~m}$ in thickness; they are characterized by low dips (less than $1^{\circ}$ ) and some gentle folds. Comprehensive discussions of the Appalachian basin were given by Woodward (1958), Roth (1968), and Colton (1970).

Sedimentation in the basin occurred throughout the Paleozoic Era and culminated at the end of this time with the final major orogeny (the Appalachian revolution) that determined the present geologic pattern. Salt and anhydrite deposits in the basin, which are principally Late Silurian in age, connect with the Salina salts of the Michigan basin to the northwest through the Chatham sag (a low place between the Findlay and Algonquin arches).

The Upper Silurian Bass Islands Dolomite directly overlies the Salina Group evaporites in Ohio (Clifford, 1973), whereas farther east, in Pennsylvania and New
York, the overlying units are the Rondout Formation, Cobleskill, or Helderberg Limestone (Rickard, 1969; Heyman, 1977). Younger Devonian, Mississippian, Pennsylvanian, and Permian deposits are chiefly clastics; they comprise the outcropping rock units in all areas underlain by the evaporites. Many of the post-Silurian sandstones contain oil and gas, and major bituminouscoal resources are being mined from rocks of Pennsylvanian age in parts of Kentucky, Ohio, Pennsylvania, and West Virginia.

Evaporites of the Salina Group underlie parts of New York, Ohio, Pennsylvania, and West Virginia (fig. 2.4). The thickness of the Salina is typically between 150 and $500 \mathrm{~m}$ in the shallow subsurface, but increases to the southeast into the basin and reaches a maximum of more than $750 \mathrm{~m}$ in the deep subsurface of north-central and southwest Pennsylvania (Rickard, 1969). The depth to the top of moderately thick evaporites also increases from about 300 to $600 \mathrm{~m}$ in the north and northwest to more than $1,500 \mathrm{~m}$ in the deep basin to the southeast (fig. 2.4).

The lithologies of the Salina Group can be correlated over large areas of the Appalachian basin. Landes (1945) originally established the major subdivisions of the Salina Group in the Michigan basin. The same subdivisions were later recognized in Ohio (Ulteig, 1964), and interbasin correlations are now well established through the work of Fergusson and Prather (1968), Rickard (1969), Jacoby (1969), Clifford (1973), Heyman (1977), and Mesolella (1978). Recognition and correlation of individual units over such a large area is greatly enhanced by the distinctive mechanical-log curves recorded for each unit in oil and gas tests.

Anhydrite is reported in each of the subdivisions of the Salina Group in various parts of the Appalachian basin (Rickard, 1969; Clifford, 1973; Smosna and others, 1977; and Mesolella, 1978), but only the uppermost unit appears to contain an anhydrite bed more than $15 \mathrm{~m}$ thick. Most of the other anhydrite beds are 1-10 m thick, and they occur chiefly in the $\mathrm{A}, \mathrm{C}$, and $\mathrm{F}$ units. The anhydrites typically are interbedded with much thicker beds of salt, dolomite, and shale, and thus individual anhydrites are scattered throughout the stratigraphic column.

The one thick anhydrite occurs at the top of the Salina Group; in northeast Ohio it is referred to as part of the G unit (Clifford, 1973; Heyman, 1977), whereas in south-central New York and northwestern Pennsylvania it is referred to as the Bertie Formation (Rickard 1969; Mesolella, 1978) (fig. 2.12). For simplicity, we will use the term G-unit anhydrite throughout the region in this report. 


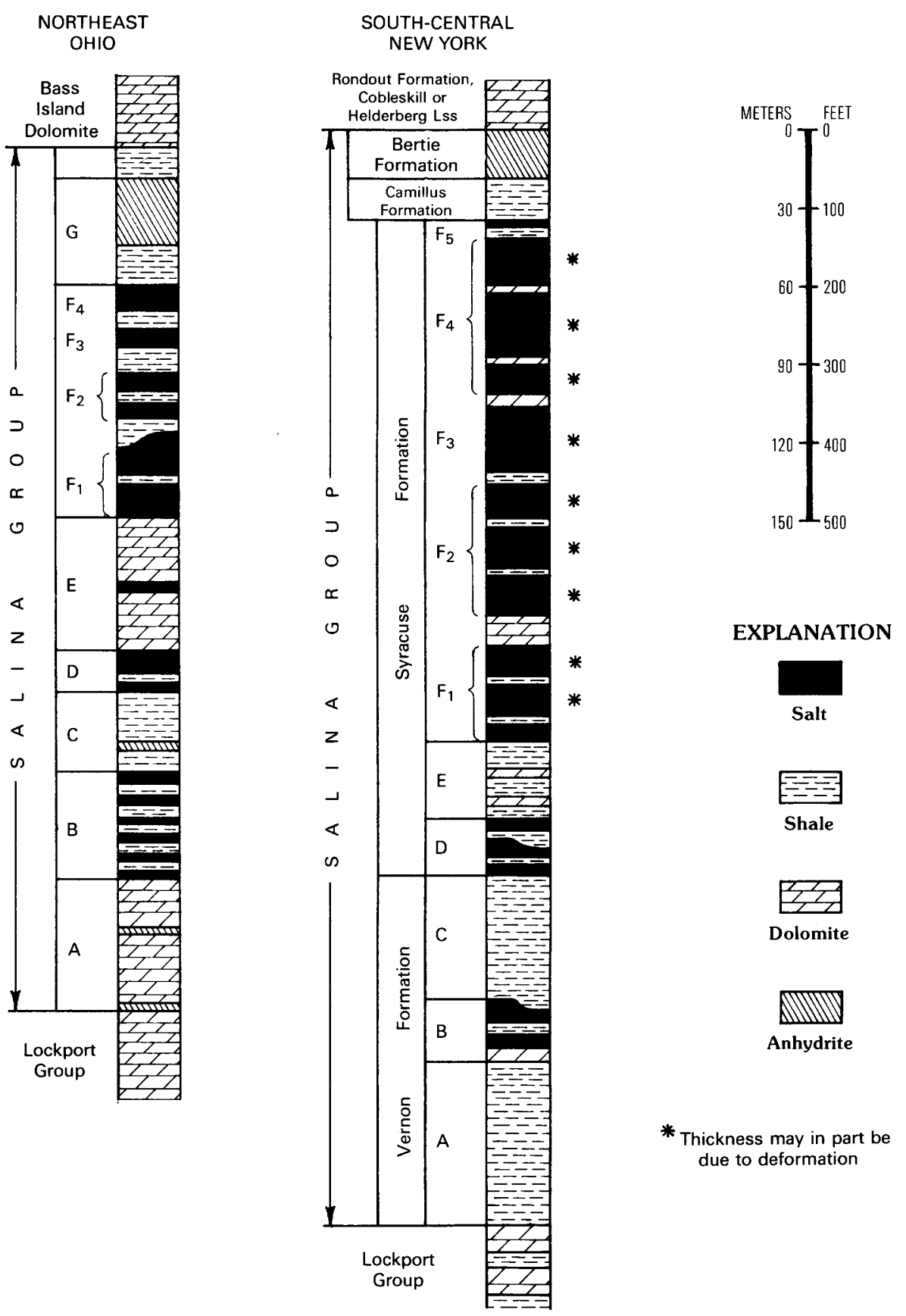

Figure 2.12. Generalized columnar sections of Salina Group in northeast Ohio and south-central New York (modified from Rickard, 1969; Clifford, 1973).

Thickness of the anhydrite in the $\mathrm{G}$ unit is $5-15 \mathrm{~m}$ in the north and west, where the unit is less than $900 \mathrm{~m}$ below the land surface, but increases toward the southeast to $30-37 \mathrm{~m}$ in parts of western Pennsylvania, eastern Ohio, and northern West Virginia (figs. 2.13 and 2.14). In this area, just north and west of Pittsburgh, the top of the $\mathrm{G}$ unit is at a depth of $1,500-2,100 \mathrm{~m}$. Figure 2.13, which shows thickness and depth of the G-unit anhydrite, is based upon scattered data points that were selected from mechanical-log cross sections presented by Clifford (1973), Heyman (1977), and Mesolella (1978). The $\mathrm{G}$ unit clearly contains anhydrite south and east of the area shown in figure 2.13 (Rickard, 1969; Smosna and others, 1977; Smosna and Patchen, 1978), but it also contains an increasing percentage of nonanhydrite rocks; additional work must be done to verify the thickness and amount of anhydrite in the deeper parts of the basin. 


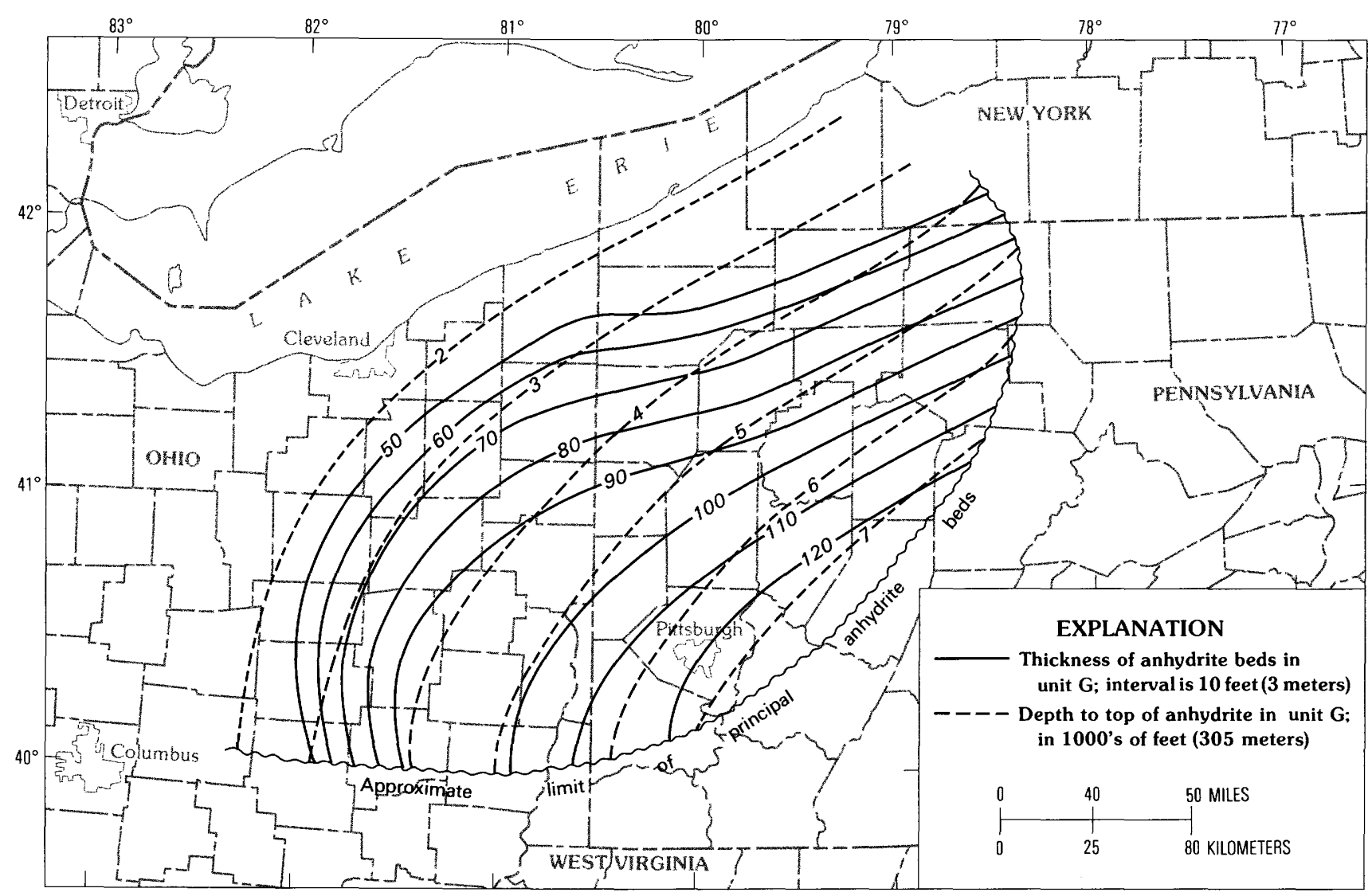

Figure 2.13. Map showing thickness, in feet, and depth to G-unit anhydrite at top of Salina Group in the Appalachian basin (based on data from Clifford, 1973; Heyman, 1977; and Mesolella, 1978).

In subsurface, the $G$ unit is variously described as anhydrite in Ohio and adjacent areas (Clifford, 1973) and as anhydritic dolomite in much of the rest of the basin (Rickard, 1969; Smosna and others, 1977; Mesolella, 1978). The area where the unit appears to consist mainly of anhydrite extends across much of eastern Ohio, western Pennsylvania, and northern West Virginia (fig. 2.13). Outside this area, the formation contains many dolomite interbeds or consists mainly of dolomite. Further lithologic studies are needed to clarify facies changes between anhydrite and dolomite.

The G-unit anhydrite is underlain and overlain by beds of shale, shaley dolomite, or dolomite that range from 15 to $60 \mathrm{~m}$ in thickness (fig. 2.12). The underlying beds are in the lower $G$ unit (Camillus Formation, according to Rickard, 1969), whereas the overlying unit is referred to in various areas as the Rondout Formation, Cobleskill or Helderberg Limestone, the Bass Islands Dolomite, or an unnamed upper unit of the Salina Group.

\section{ADIRONDACK UPLIFT_PRECAMBRIAN}

Subsurface and surface data from the BalmatEdwards district in St. Lawrence County, N.Y., show that Precambrian rocks contain gypsum and anhydrite as part of a metamorphic complex (Brown and Engel, 1956; Brown, 1973). The sulfate unit, which is associated with gypsiferous schist and diopsidic marble, comprises part of the Grenville Complex in this northwest part of the Adirondack uplift (fig. 2.1). The relation of the gypsum and anhydrite to the associated units suggests a sedimentary origin for the calcium sulfate beds. The sulfate unit thins and thickens abruptly because of intense deformation of the region, and the maximum thickness occurs in the apex of a tight fold where gypsum and anhydrite are mixed with adjacent marble in a unit at least $60 \mathrm{~m}$ thick. Anhydrite has been found at depths greater than $800 \mathrm{~m}$ in some of the magnetite and lead-zinc-pyrite mines of the district. 
A

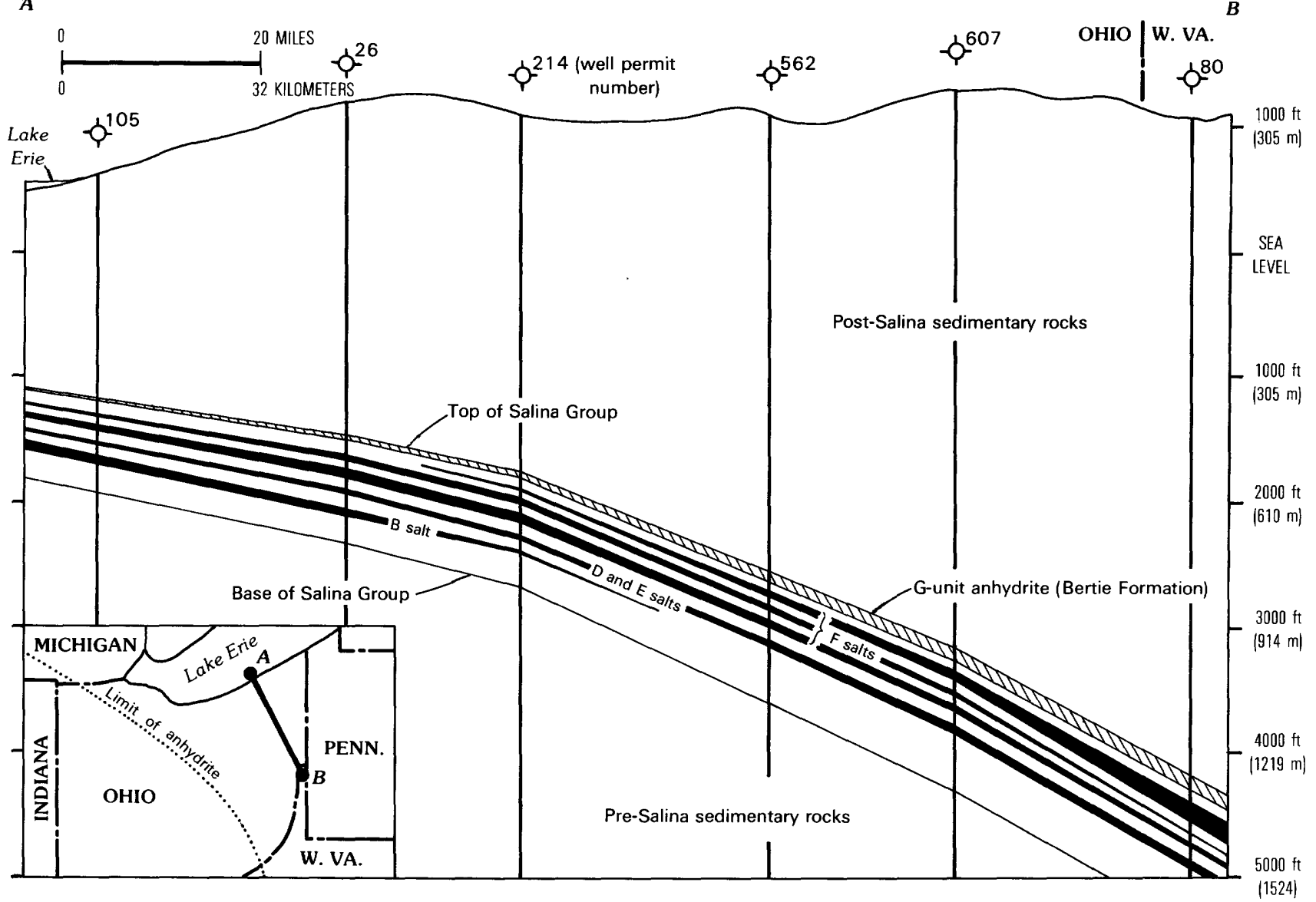

Figure 2.14. Generalized north-south cross section in northeastern Ohio showing position and depth of G-unit anhydrite and principal salt units of the Salina Group (based on data from Clifford, 1973).

\section{SALTVILLE AREA (VIRGINIA)- MACCRADY FORMATION}

Anhydrite and salt are present in a tectonic breccia in the Maccrady Formation of Mississippian age in the tightly folded and faulted Valley and Ridge province around Saltville in Smyth and Washington Counties of the western part of Virginia (fig. 2.1). The evaporites have been little studied, although brine wells and gypsum mines have operated here since the early 1800's. Gypsum and anhydrite occur together in the mines as lenses and irregular masses as much as $30 \mathrm{~m}$ thick and $200 \mathrm{~m}$ long. Cooper (1966) is the principal source of data on the Saltville area.

The structure of the evaporite beds is complicated. Salt and anhydrite are preserved in a major fold-the Greendale syncline-which has been overturned on the south limb and has been overridden by Cambrian rocks that form the sole of the Saltville thrust (Cooper, 1966).
The Maccrady beds are highly contorted with dips of $25^{\circ}$ to $70^{\circ}$.

In some of the deeper brine wells of the area, the Maccrady Formation is $450-510 \mathrm{~m}$ thick and contains considerable amounts of salt, gypsum, anhydrite, dolomite, and limestone interbedded with red and green plastic shale (Cooper, 1966). The number of beds, lenses, or pods of gypsum and anhydrite varies from place to place, but nearly every borehole shows several occurrences of sulfate rocks. Hydration of anhydrite to gypsum apparently occurs as deep as $300 \mathrm{~m}$ in some wells, but in other wells anhydrite is still present at shallow depths. In the mines, gypsum and anhydrite occur together in masses and pods that are irregular in shape because of deformation and some flowage.

Cores taken from the overturned (upper) limb of the Greendale syncline in 1961 provide some information on the character of the evaporites at depth. Salt and anhydrite occur in zones of tectonic breccia that contain fragments of shale, anhydrite, limestone, and dolomite 
suspended in a matrix of salt (Cooper, 1966). Apparently, the original primary sequence that consisted of salt and anhydrite interbedded with the other rock types was sheared and broken up during overthrusting. Therefore, a large body of thick and undeformed anhydrite is not likely to be present at moderate depth in the Saltville area.

\section{ILLINOIS BASIN-ST. LOUIS LIMESTONE}

The St. Louis Limestone of Late Mississippian age contains several gypsum and anhydrite beds 1-15 m thick in the Illinois basin area of southern Illinois, southwest Indiana, and northwest Kentucky (fig. 2.15). Studies of these evaporites were reported by Saxby and Lamar (1957) in Illinois; by McGregor (1954), Bundy (1956), French and Rooney (1969), and Jorgensen and Carr (1972) in Indiana; and by McGrain and Helton (1964) in Kentucky. The evaporite-bearing zone in the lower part of the St. Louis Limestone generally ranges from 15 to $75 \mathrm{~m}$ in thickness, and is typically from 100 to $1,000 \mathrm{~m}$ in depth.

Limestone is the dominant rock type, even where evaporites make up part of the formation; gypsum, anhydrite, and dolomite are present as interbeds 1-15 m thick. Gypsum and anhydrite beds are 1-5 m thick in most parts of the region, and only in two small areas of Illinois are they 10-15 m thick (Saxby and Lamar, 1957). Both gypsum and anhydrite typically are nodular. The uppermost evaporite beds in Indiana are more likely to be gypsum than are the lower beds, and anhydrite increases in proportion to gypsum with increasing depths (Bundy, 1956). In Illinois, the evaporites are chiefly gypsum at depths less than $250-300 \mathrm{~m}$, and are mainly anhydrite at depths greater than 350-450 m (Saxby and Lamar, 1957). In all areas, the evaporite units are rather impure; typically, they consist of 75-90 percent anhydrite and (or) gypsum, and the rest is limestone and some dolomite.

Commercial deposits of gypsum are being mined underground by two companies in the Shoals district of Martin County, Ind. (French and Rooney, 1969; Jorgensen and Carr, 1972). An inclined shaft and a vertical shaft have been opened to exploit a 5-m-thick gypsum bed in the St. Louis Limestone 100-150 m below the surface.

\section{FOREST CITY BASIN-DEVONIAN, MISSISSIPPIAN, AND JURASSIC}

Thin to moderately thick beds of anhydrite occur in Paleozoic carbonate sequences on the northeast shelf of the Forest City basin in central and southern Iowa

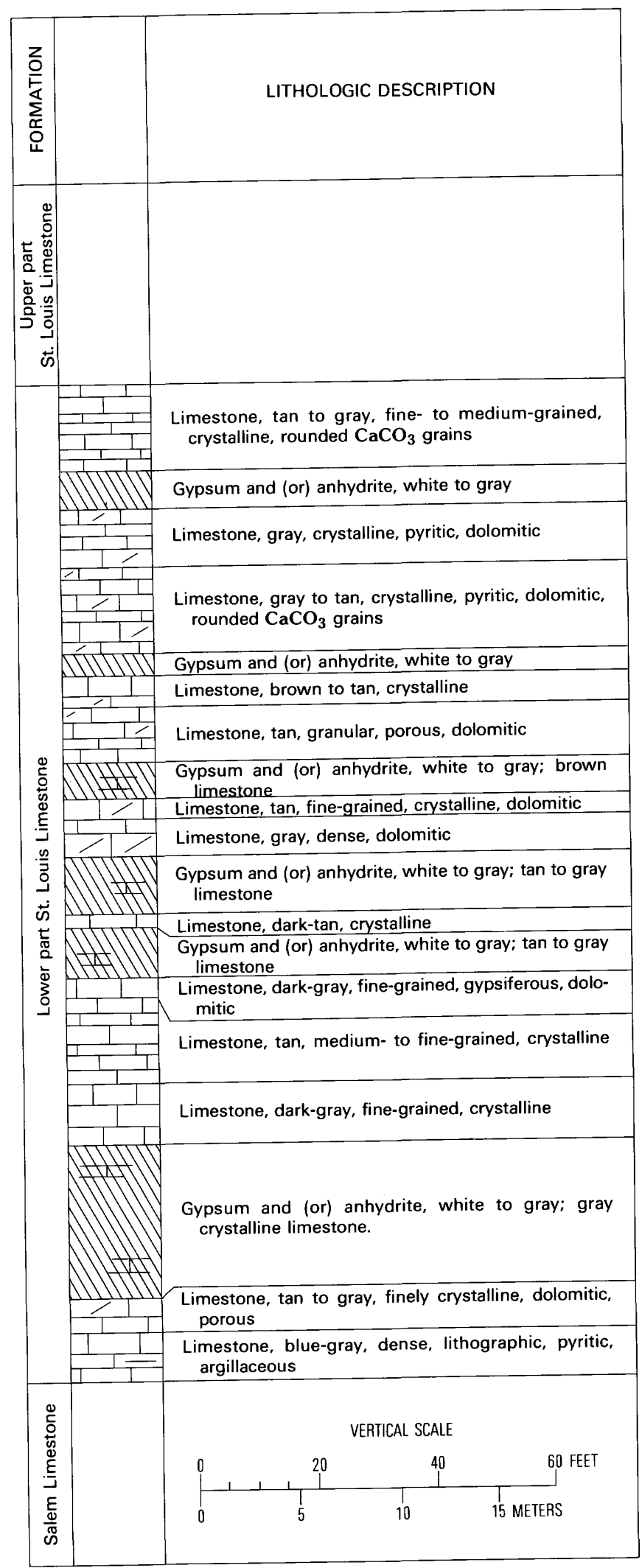

Figure 2.15. Generalized stratigraphic section showing evaporite units in the lower part of the St. Louis Limestone in southwest Indiana (modified from McGregor, 1954). Entire section shown here is in Meramecian Series of Mississippian System. 
fig 2.1). Anhydrite-bearing rock units are the Wapsipinicon and Cedar Valley Limestones of Devonian age and the Warsaw and St. Louis Limestones of Mississippian age. Gypsum also occurs as a single 9-m-thick bed in the Jurassic Fort Dodge Formation in outcrops and shallow subsurface in a small area of central Iowa. The Devonian occurrences were reported by Dorheim and Campbell (1958), Collinson and others (1967), and Sendlein (1973); the Mississippian deposits were described by Dorheim and Campbell (1958) and Perry (1971); and the Jurassic gypsum was described by Stone and others (1920).

Anhydrite and gypsum beds of the Devonian and Mississippian formations are typically 2-5 m thick over most of the basin, although they are at least $15 \mathrm{~m}$ thick at two localities in south-central Iowa. Near Albia, in Monroe County, Iowa, the upper $18 \mathrm{~m}$ of the Warsaw Limestone is chiefly anhydrite and gypsum, and this formation includes a $15-\mathrm{m}$-thick bed at a depth of $90 \mathrm{~m}$ that is mostly anhydrite (Dorheim and Campbell, 1958). Also, near Ottumwa, in Wapello County, Iowa, the Wapsipinicon Limestone contains a 30-m-thick interval at a depth of about $300 \mathrm{~m}$ that is mostly anhydrite but that has some interbeds of limestone (Dorheim and Campbell, 1958). Gypsum in the Wapsipinicon is being mined underground in Des Moines County in southeastern Iowa.

Gypsum in the Fort Dodge Formation underlies an area of about $150 \mathrm{~km}^{2}$ near Fort Dodge, in Webster County, Iowa. Total thickness of the gypsum ranges from 3-9 m, and it is buried beneath only 5-20 m of glacial drift. Gypsum in this area has been mined extensively since the late 1800 's.

\section{SOUTH FLORIDA BASIN- CRETACEOUS AND TERTIARY}

The South Florida basin contains thick sequences of anhydrite and carbonate in both the Lower Cretaceous and the lower Tertiary (Paleocene). Some individual anhydrite beds in the Cretaceous are as much as to $50 \mathrm{~m}$ thick and exist at depths ranging from about 2,000 $\mathrm{m}$ to more than $3,000 \mathrm{~m}$ below the surface; thinner anhydrite beds extend farther updip to depths of about $1,500 \mathrm{~m}$. The Paleocene anhydrite beds are generally less than 25 $\mathrm{m}$ thick and are at depths of 400-1,200 m. Principal references on the Lower Cretaceous anhydrites are Applin and Applin (1965), Ogelsby (1967), Rainwater (1971b), Winston (1971, 1976), and Feitz (1976), whereas principal references on anhydrites in the Paleocene are by Rainwater (1970a, 1971b).

The South Florida basin and other parts of peninsular Florida were tectonically stable throughout the Mesozoic and Cenozoic Eras (Rainwater, 1971b).
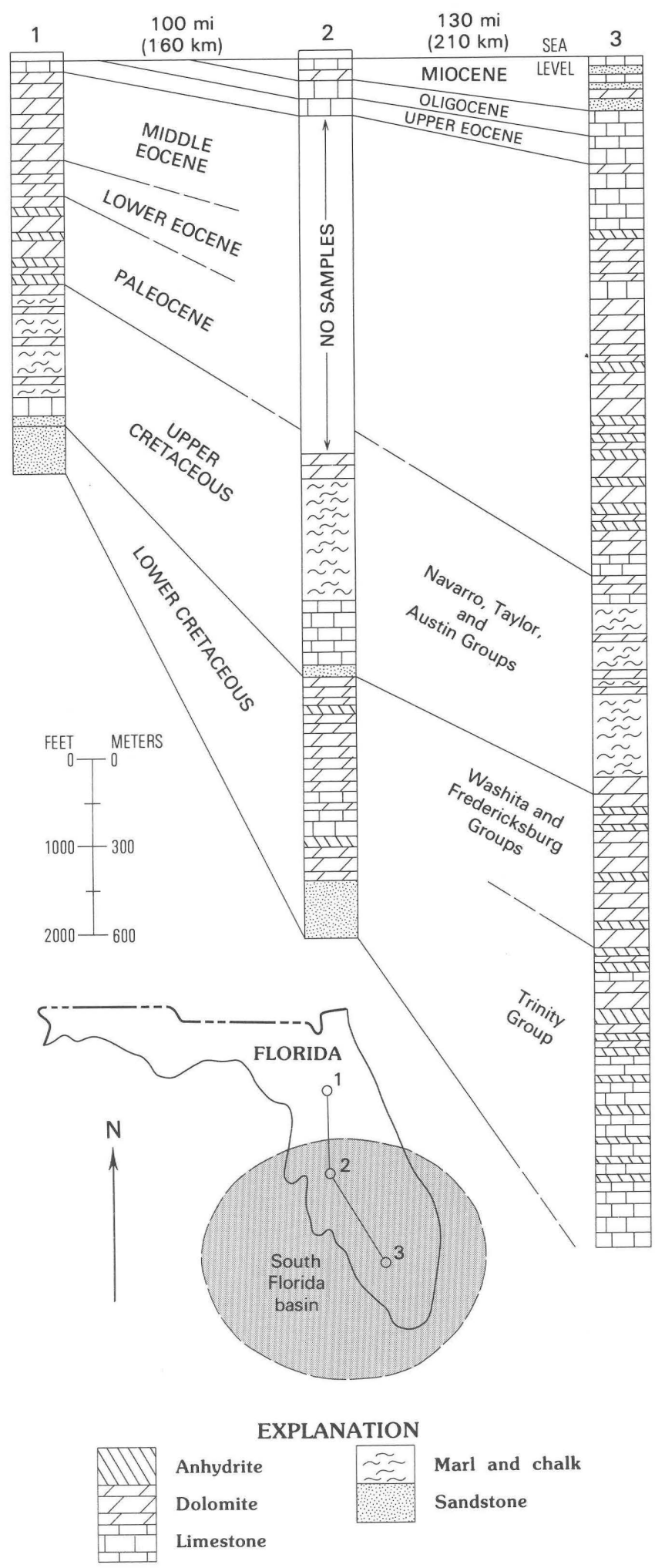

Well logs used in cross section:

1. Sun Oil Co., No. 1 Camp; Marion County

2. Humble O \& R Co., No. 1 Jameson; Hillsborough County

3. Composite log, Suniland field; Collier County

Figure 2.16. Structural cross section showing thickening of Lower Cretaceous and lower Tertiary carbonate-anhydrite sequences into the South Florida basin (modified from Rainwater, 1971a, b).

Distribution and Geologic Characteristics of Anhydrite Deposits 


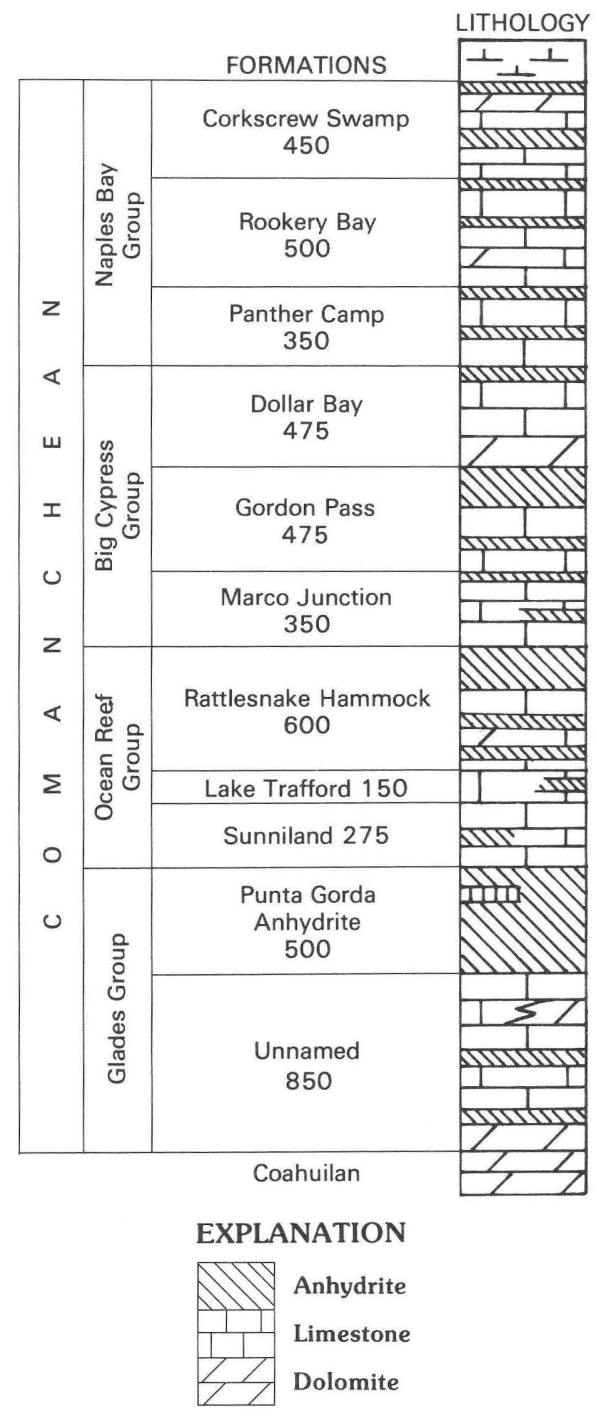

Figure 2.17. Generalized geologic column of Lower Cretaceous strata in the South Florida basin (modified from Winston, 1976). Numbers are average thicknesses of formations, in feet.

Regional subsidence during this time permitted deposition of more than $3,000 \mathrm{~m}$ of Cretaceous and Tertiary shallow-marine carbonates and evaporites (fig. 2.16). A thinner sequence of interbedded carbonates and clastics was deposited in coastal-plain environments in the more slowly subsiding northern part of Florida. Strata in the region now dip gently to the south toward the deep part of the basin; they are not faulted, folded, or otherwise disturbed. The South Florida basin subsided at a faster rate than did adjacent areas, and most of the anhydrite accumulated in this basin. In general, the anhydrite units grade laterally into carbonates toward the north, and then into clastics where they are at still shallower depths (fig. 2.16).

Lower Cretaceous (Comanchean) carbonateevaporite strata in the basin range in thickness from about $1,000 \mathrm{~m}$ in the north, where they interfinger with clastics, to more than $2,000 \mathrm{~m}$ near the basin center (fig. 2.16). The thick carbonate-evaporite sequence has been subdivided into four groups consisting of 11 formations (fig. 2.17). Individual formations generally range in thickness from 50 to $300 \mathrm{~m}$, and each consists of interbedded limestone, dolomite, and nodular anhydrite. Rock salt also is present in the deepest part of the basin in layers that are typically less than $3 \mathrm{~m}$ thick and that aggregate only about $10 \mathrm{~m}$ thick.

Anhydrite beds in the various Lower Cretaceous formations are mostly $3-10 \mathrm{~m}$ thick, and they are typically about 1,500-3,000 $\mathrm{m}$ below the land surface. The thicker individual anhydrite beds, which are 15-50 m thick, are in the Punta Gorda, Sunniland, Rattlesnake Hammock, and Gordon Pass Formations. Feitz (1976) correlated the Punta Gorda Anhydrite with the Ferry Lake Anhydrite, which is present throughout much of the central and western parts of the Gulf Coast basin. An additional, even deeper group of carbonates and anhydrite occurs in the Fort Pierce Formation in the Upper Jurassic(?) or Lower Cretaceous(?) of the South Florida basin (Applin and Applin, 1965).

Details on the character, thickness, distribution, and depth of individual Lower Cretaceous anhydrite beds are presented by Applin and Applin (1965). The thicker beds appear to be restricted to the deeper parts of the basin where they are more than $2,000 \mathrm{~m}$ below the surface. The updip limit of the evaporite facies in the Lower Cretaceous is in the Citrus-Sumter-Lake-Volusia County area, where the evaporites are at a depth of about $1,500 \mathrm{~m}$; in this area the anhydrite beds are probably no more than several meters thick.

Lower Tertiary (Paleocene) strata of the South Florida basin and nearby areas are interbedded dolomite, anhydrite, and limestone in the Cedar Keys Limestone. These strata were deposited on a slowly subsiding shelf that had a restricted connection to the open ocean. They grade laterally into clastic sediments in northernmost Florida (figs. 2.16 and 2.18).

Total thickness of the Paleocene carbonateevaporite sequence ranges from about $100 \mathrm{~m}$ in the north to about $700 \mathrm{~m}$ in the south. Anhydrite beds were shown by Rainwater (1971b) to range from $10 \mathrm{~m}$ to about $25 \mathrm{~m}$ in thickness (fig. 2.18), although detailed information on individual anhydrite beds is not readily available. The depth to the top of anhydrite-bearing strata is about 


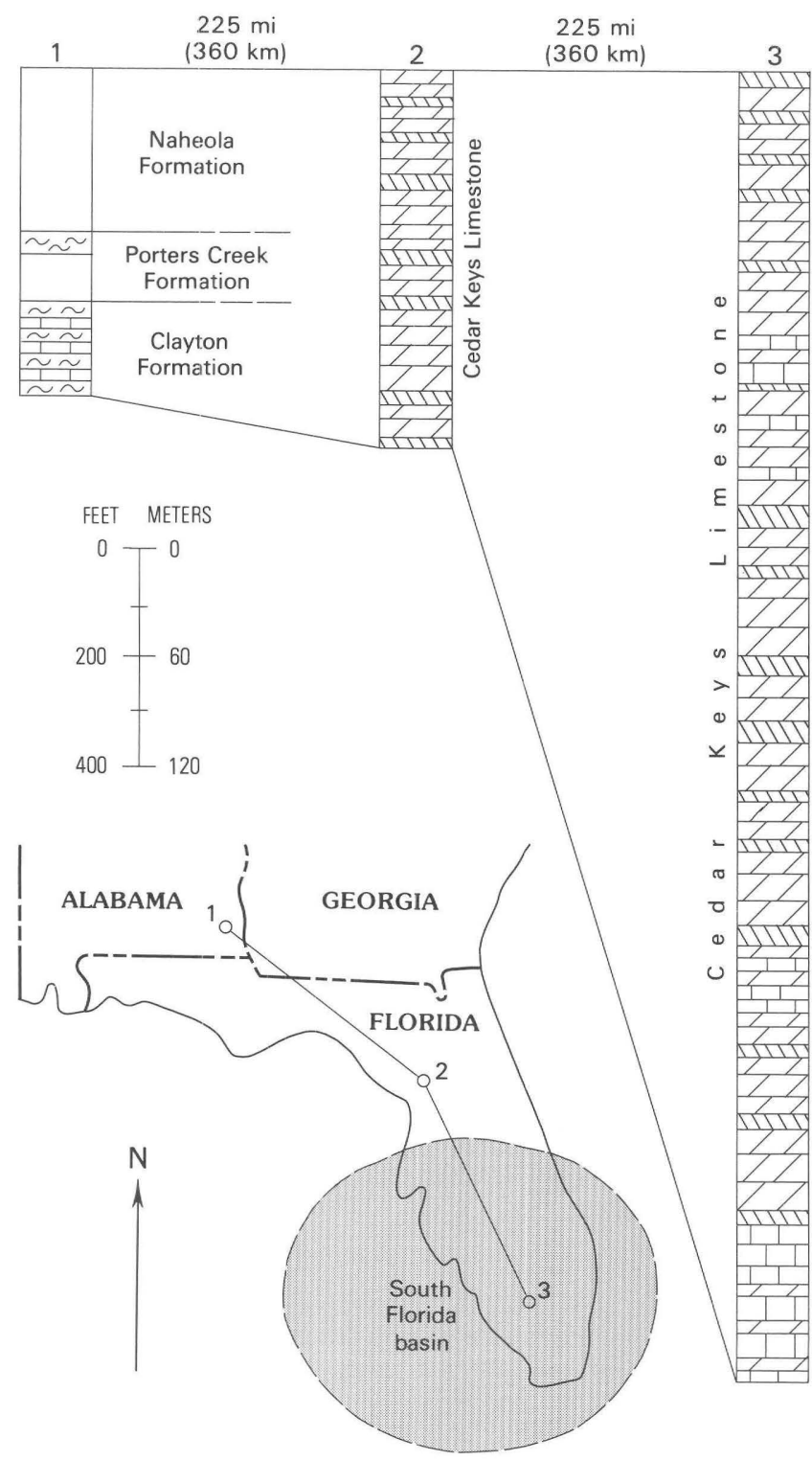

EXPLANATION

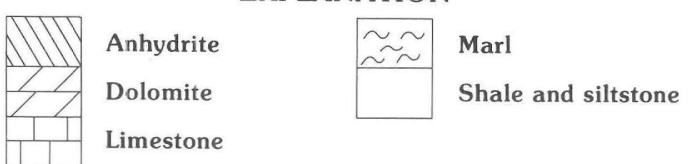

Generalized stratigraphic sections for:
1. Southeastern Alabama
2. Northwestern-peninsular Florida
3. South Florida Basin

Figure 2.18. Generalized stratigraphic sections showing lithology representative of Paleocene strata from southeastern Alabama to the South Florida basin (modified from Rainwater,1971b).
$400 \mathrm{~m}$ in the north part and increases to about $1,200 \mathrm{~m}$ in the deep part of the South Florida basin (fig. 2.16). Because these anhydrite beds are reported to be as much as $25 \mathrm{~m}$ thick and are at moderate depth, further study of their thickness, character, and distribution may be warranted.

\section{GULF COAST BASIN}

\section{Structure and Geologic Framework}

The Gulf Coast basin referred to in this report is the northern part of the Gulf of Mexico basin, and it extends westward from Alabama through Mississippi and Louisiana into southern Arkansas and Texas, and southward under the Gulf of Mexico. This significant regional feature appears to have originated in the early Mesozoic, but did not reach maximum development, as measured by pronounced subsidence and sediment infilling, until the Cenozoic. The stratigraphic section ranges in thickness from less than $1,000 \mathrm{~m}$ along the arcuate northern boundary of the basin to possibly as much as $18,000 \mathrm{~m}$ in southern Louisiana and in the near-offshore regions of the Gulf of Mexico.

Since the mid-Mesozoic, the depositional axis of the basin has shifted progressively southward toward the present-day Gulf of Mexico. The greatest sedimentation took place during the Tertiary and was dominated by clastic deposits. Regional facies changes are important aspects of petroleum exploration in this major petroleum-producing province. The development of the Cenozoic sequence was controled by prograding depositional systems, fluctuating water depths, and localized sedimentation rates that were dictated by faults. The evaporites of Jurassic and Early Cretaceous age are of special importance to this report because they are thick and widespread, and are source beds for the numerous salt domes in the Gulf Coast basin.

The regional strikes of the various outcrop and subcrop belts essentially parallel the coastline. Cretaceous outcrops in the north give way to successively younger Cenozoic (Eocene to Pliocene-Pleistocene) intervals in a gulfward direction. Although the regional dip is also gulfward (south), faults and other structures create localized areas of dip reversal. The subsurface geology is complicated by facies changes, regional and local faulting, and numerous salt-related structures. The regional character of the Gulf Coast basin is seen in the structure map drawn on top of the Lower Cretaceous 


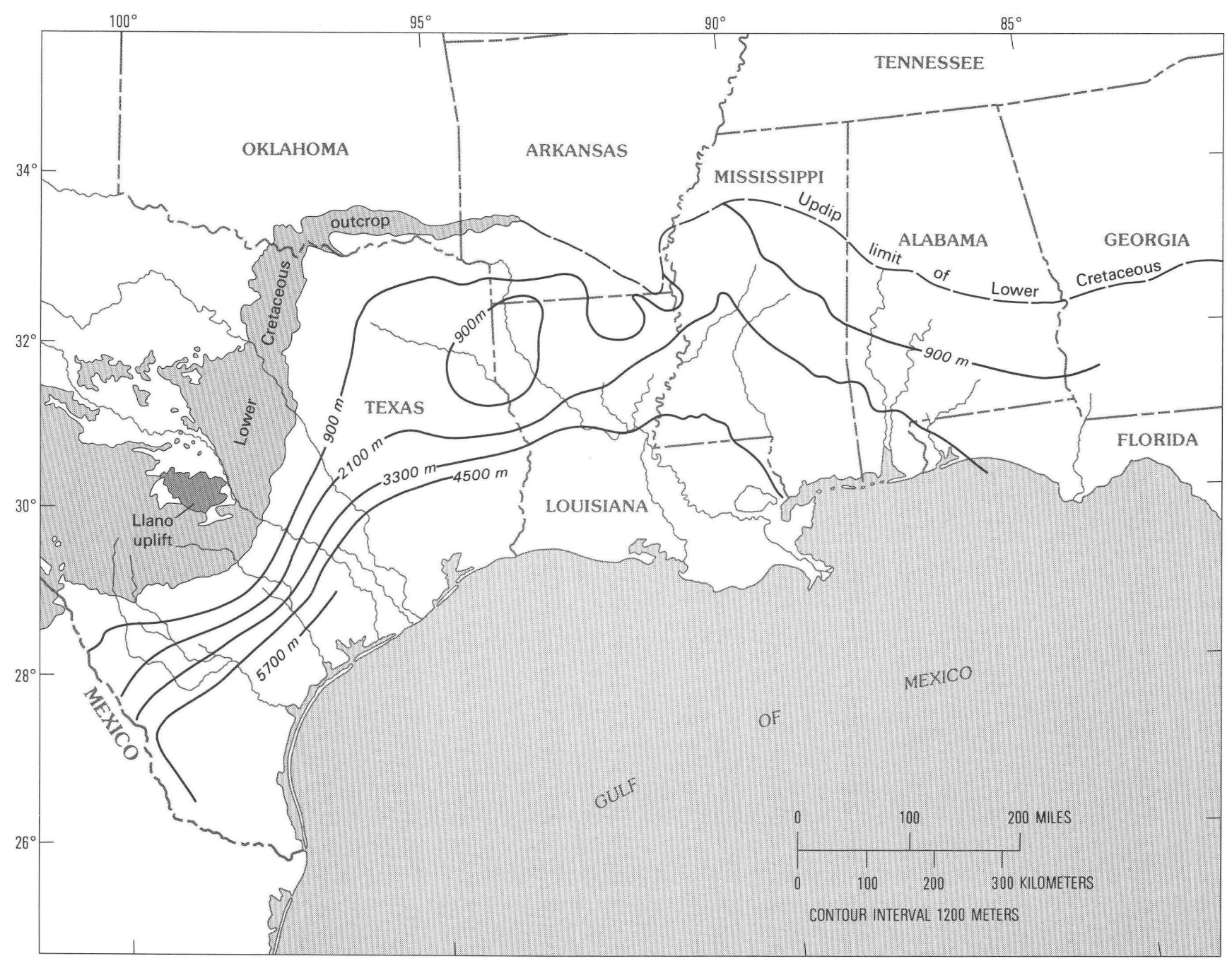

Figure 2.19. Structure map on top of Lower Cretaceous strata in Gulf Coast basin (modified from Rainwater, 1971a). Elevations, in meters, are below sea level.

(fig. 2.19). Strata dip toward the Gulf at fairly uniform rates of about $0.5^{\circ}-1^{\circ}$ in most areas; however, the dip is $2^{\circ}-3^{\circ}$ in much of Texas, and it is reversed over the Sabine uplift in the Shreveport area and over the Wiggins arch in southeastern Mississippi.

Each of the Jurassic and Lower Cretaceous evaporites in the basin (fig. 2.20) is a widespread unit that has been used as a stratigraphic marker in petroleum exploration. The Werner, Buckner, and Ferry Lake Formations are typically $15-100 \mathrm{~m}$ thick and consist mainly of anhydrite. They all occur at depths of less than 1,500 $\mathrm{m}$ beneath the surface in southern Arkansas, and one or more of them also occurs at similar depths in parts of adjacent east Texas, northern Louisiana, and westcentral Mississippi. These anhydrite-bearing formations are more than 1,500 $\mathrm{m}$ deep elsewhere in the Gulf Coast basin, and they increase to more than $3,000 \mathrm{~m}$ deep toward the Gulf of Mexico.

Regional structural trends of the Gulf Coast basin are disrupted in many places by diapiric salt domes that have their source in the deep-seated Louann Salt (Upper and Middle Jurassic). The domes, many of which have a cap rock composed mainly of anhydrite, formed initially near the northern edge of the salt deposits (fig. 2.21), and they progressively developed farther southward through geologic time in response to increasingly greater burial 


\begin{tabular}{|c|c|c|c|c|c|c|c|}
\hline ERA & SYSTEM & SERIES & GROUP & EAST TEXAS & $\begin{array}{l}\text { LOUISIANA- } \\
\text { ARKANSAS }\end{array}$ & MISSISSIPPI & ALABAMA \\
\hline \multirow{7}{*}{$\cup$} & \multirow{13}{*}{ 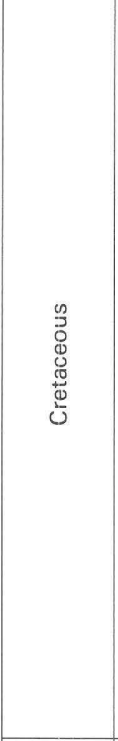 } & \multirow{11}{*}{$\begin{array}{l}\frac{c}{0} \\
\mathbb{d} \\
\frac{0}{0} \\
0 \\
\frac{C}{\pi} \\
\tilde{E} \\
0 \\
0\end{array}$} & \multirow{4}{*}{ Washita } & Maness Sh & \multirow{4}{*}{ Undifferentiated } & \multirow{4}{*}{ Dantzler $\mathrm{Fm}^{1}$} & \multirow{6}{*}{ Undifferentiated } \\
\hline & & & & Buda Ls & & & \\
\hline & & & & Grayson Sh & & & \\
\hline & & & & Georgetown Ls & & & \\
\hline & & & \multirow{2}{*}{ Fredericks burg } & Kiamichi Fm & Kiamichi Fm & \multirow{2}{*}{ Andrew Limestone ${ }^{2}$} & \\
\hline & & & & Goodland Ls & Goodland Ls & & \\
\hline & & & \multirow{7}{*}{ Trinity } & Paluxy Sand & Paluxy Sand & Paluxy Sand & Paluxy Sand \\
\hline- & & & & Glen Rose Ls & Mooringsport Fm & Mooringsport Fm & Mooringsport Fm \\
\hline ○ & & & & $\begin{array}{l}\text { Ferry Lake } \\
\text { Anhydrite }\end{array}$ & $\begin{array}{l}\text { Ferry Lake } \\
\text { Anhydrite }\end{array}$ & $\begin{array}{l}\text { Ferry Lake } \\
\text { Anhydrite }\end{array}$ & $\begin{array}{l}\text { Ferry Lake } \\
\text { Anhydrite }\end{array}$ \\
\hline$N$ & & & & Rodessa Fm & Rodessa Fm & \multirow{2}{*}{$\begin{array}{l}\text { Rodessa, James, and } \\
\text { Pine Island Fms }\end{array}$} & Rodessa Fm \\
\hline 0 & & & & Pearsall Fm & Pearsall Fm & & Pine Island Fm \\
\hline \multirow{2}{*}{$\omega$} & & \multirow{2}{*}{$\begin{array}{l}\frac{5}{\pi} \\
\frac{\pi}{3} \\
\frac{1}{\pi} \\
0 \\
ن\end{array}$} & & Sligo Fm & Sligo Fm & Sligo Fm & Sligo Fm \\
\hline & & & & Hosston Fm & Hosston Fm & Hosston Fm & Hosston Fm \\
\hline \multirow{7}{*}{$\Sigma$} & \multirow{7}{*}{$\begin{array}{l}0 \\
0 \\
0 \\
0 \\
0 \\
\frac{5}{3} \\
\Rightarrow\end{array}$} & \multirow{6}{*}{ Upper } & \multirow{5}{*}{$\begin{array}{l}\text { Cotton } \\
\text { Valley }\end{array}$} & Schuler Fm & Schuler Fm & \multirow{2}{*}{$\begin{array}{c}\text { Cotton Valley } \\
\text { Fm }\end{array}$} & \multirow{2}{*}{$\begin{array}{c}\text { Cotton Valley } \\
\text { Fm }\end{array}$} \\
\hline & & & & Bossier Fm & Bossier Fm & & \\
\hline & & & & $\begin{array}{l}\text { Haynesville and } \\
\text { Buckner Fms }\end{array}$ & $\begin{array}{l}\text { Haynesville and } \\
\text { Buckner Fms }\end{array}$ & $\begin{array}{l}\text { Haynesville and } \\
\text { Buckner Fms }\end{array}$ & $\begin{array}{l}\text { Haynesville and } \\
\text { Buckner Fms }\end{array}$ \\
\hline & & & & Smackover Fm & Smackover Fm & Smackover Fm & Smackover Fm \\
\hline & & & & Norphlet Fm & Norphlet Fm & Norphlet Fm & Norphlet Fm \\
\hline & & & & Louann Salt & Louann Salt & Louann Salt & Louann Salt \\
\hline & & Middle & & Werner Fm & Werner Fm & Werner Fm & Werner Fm \\
\hline
\end{tabular}

${ }^{1}$ Not part of Washita Gp

2 Thought to correlate with Washita and Fredericksburg Groups

Figure 2.20. Correlation chart of Jurassic and Lower Cretaceous strata in the Gulf Coast basin (modified from Newkirk, 1971; Rainwater, 1971a; Johnson and Gonzales, 1978). Principal anhydrite-bearing formations are stippled.

by successively younger sediments. The great influx of Tertiary clastics clearly made a significant impact on the generation of domes nearest the present Gulf of Mexico.

The Gulf Coast basin actually consists of several smaller basins that are separated by various positive structural features such as the San Marcos arch, Sabine uplift, Wiggins arch, and Monroe uplift. The salt-dome basins include: (1) South Texas, (2) Northeast Texas, (3) North Louisiana, (4) Mississippi, and (5) TexasLouisiana coast (fig. 2.22). The latter contains salt domes both onshore and offshore.

For more comprehensive treatment of the geology of the Gulf Coast basin, references by Murray (1961),
Halbouty (1967), the Lafayette and New Orleans Geological Societies (1968), and Mason and others (1971) provide both detailed discussion and extensive bibliographic citations. The comprehensive bibliography compiled by Braunstein (1970) also contains many useful references.

\section{Salt-Dome Cap Rock}

The Gulf Coast basin is one of the most significant salt-dome provinces in the world. As shown in figure 2.22 , more than 260 domes are either known or inferred 

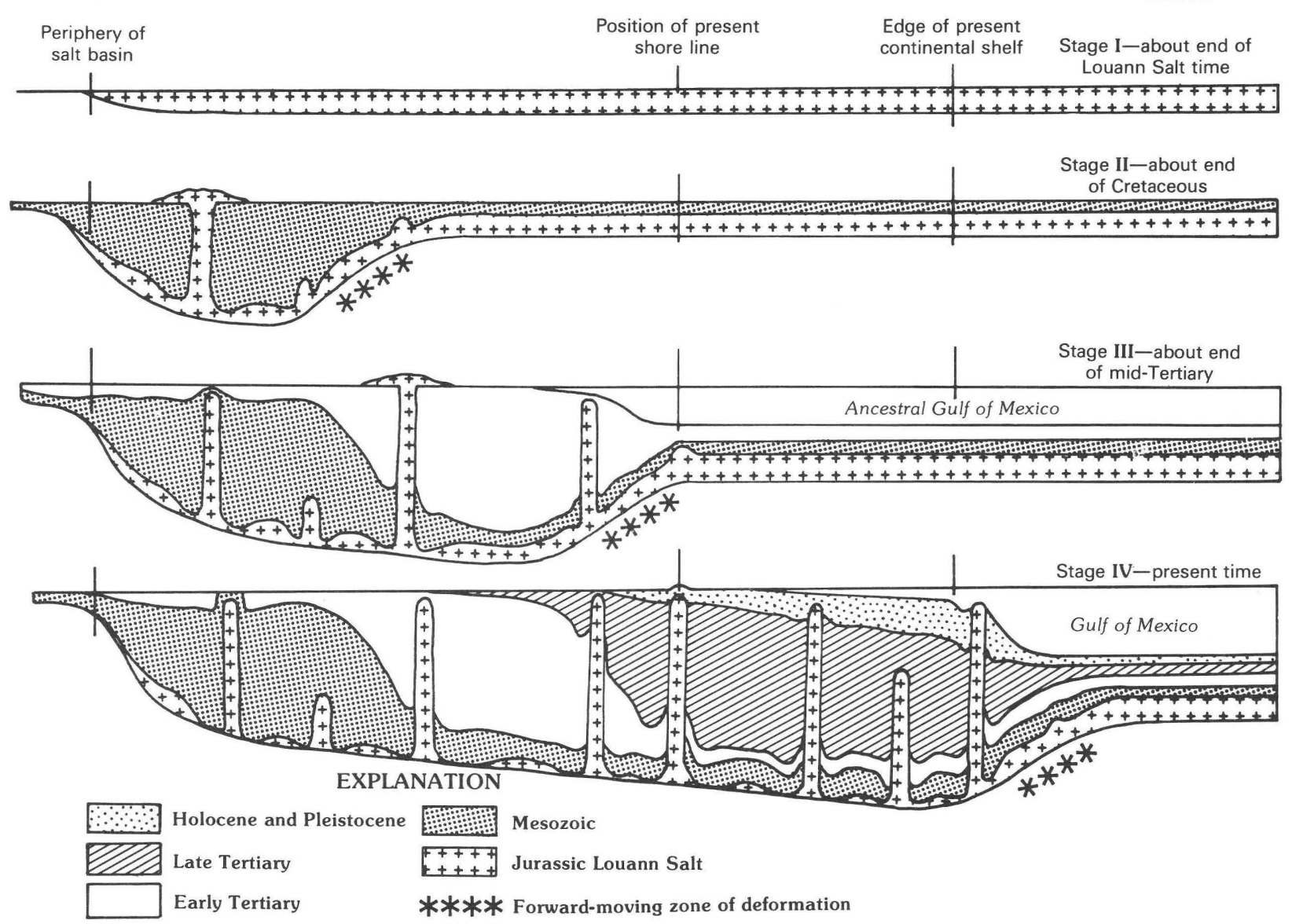

Figure 2.21. Generation of Gulf Coast salt domes through geologic time (modified from Hanna, 1959; Johnson and Gonzales, 1978).

from the onshore part of this region alone. About half of the known domes have cap rock, and many of these cap-rock units are composed mainly of anhydrite. The thickness of anhydrite in cap rock generally ranges from 25 to $240 \mathrm{~m}$, and the depth ranges from $100 \mathrm{~m}$ to more than $1,000 \mathrm{~m}$. The lithology of cap rock is variable from dome to dome, as well as on any single dome, and the upper parts of the cap rock commonly are fractured and brecciated. Much of the data that follow on the nature and origin of cap rock are based on the report by Walker (1974). Additional general studies focusing on cap rock include those of Goldman (1933, 1952), Taylor (1937, 1938), and Murray $(1966,1968)$.

Because of several unique characteristics and economically important associations of petroleum, native sulfur, and salt, salt domes of the Gulf Coast basin have been the targets of intensive geologic and geophysical investigations. Spooner (1926), Atwater and Forman (1959), Durham (1960), Hawkins and Jirik (1966), Halbouty (1967), and the Louisiana Department of Conservation (1975) discussed the Gulf Coast salt domes from a regional perspective. Additional references, many about specific domes, individual dome-related features, and petroleum fields associated with domes, can be found in the extensive bibliography compiled by Braunstein and O'Brien (1968). Reports by Pierce and Rich (1962), Gera (1972), Anderson and others (1973), Ledbetter and others (1975), Martinez and others (1975, 1976), Netherland, Sewell and Associates, Inc. (1976a, 1976b), and Johnson and Gonzales (1978) focus more specifically on the potential use of salt in the Gulf Coast salt domes for the geologic storage of radioactive wastes. 


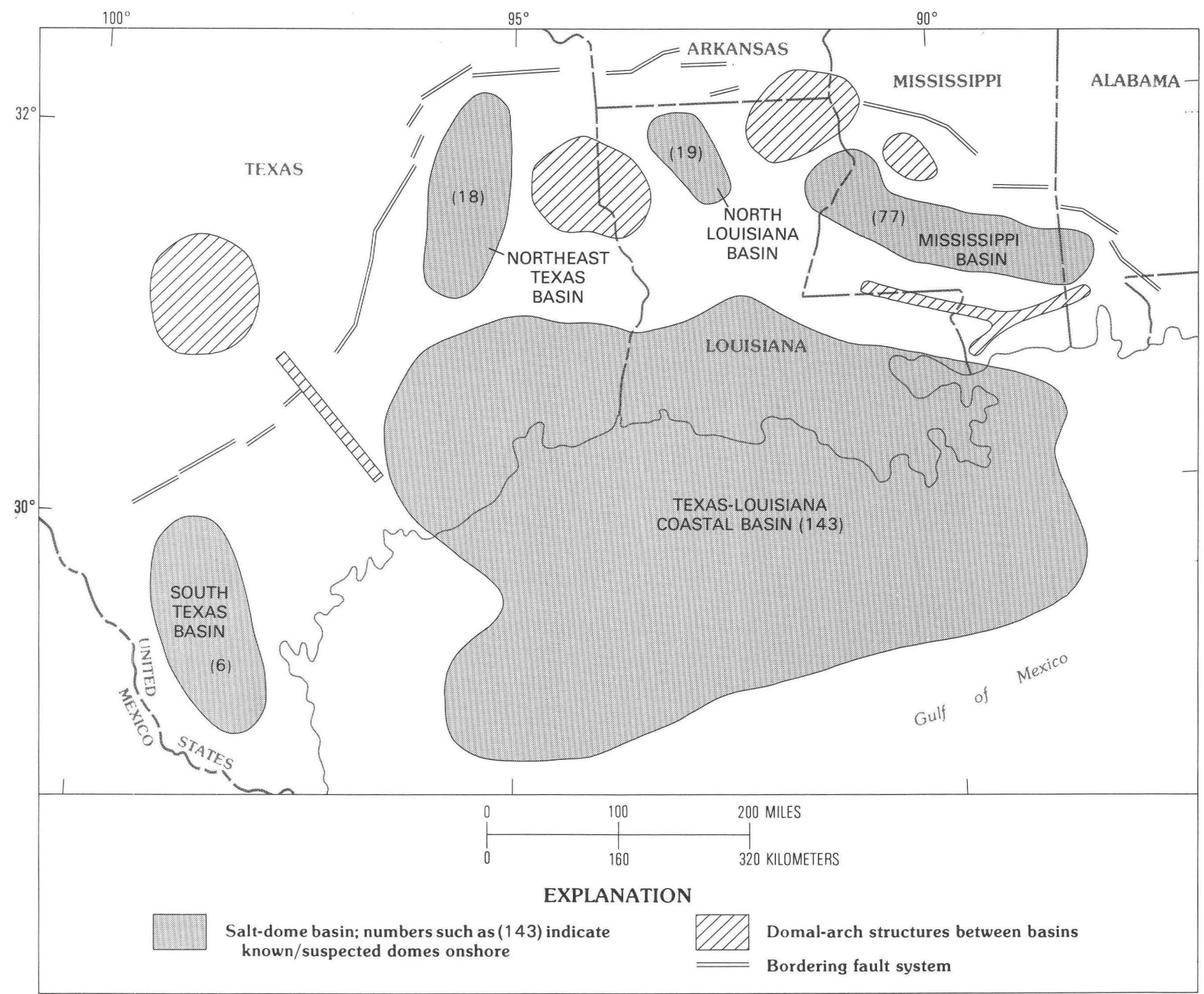

Figure 2.22. Map showing five salt-dome basins and other principal regional structural features in Gulf Coast region (modified from Johnson and Gonzales, 1978).

The exact origin of salt domes in the Gulf Coast basin is not fully understood, but most prevailing views involve flowage and upward movement of plastically deformed salt in response to overburden pressure from the overlying sediments (Martinez, 1974). Once the upward movement is started, the top of the lighter salt mass can intrude into and through the overlying, more dense sediments (fig. 2.21). In fact, some of the salt domes, particularly those in the coastal basins, appear to be tectonically active and may still be rising (Gera, 1972).

Although most salt domes are roughly circular in plan view and range in diameter from about $1 \mathrm{~km}$ to more than $6 \mathrm{~km}$, the diversity is great in dome geometries, dome-to-cap-rock relationships, and dome- to-flank-rock orientations. The height of salt domes above their base is variable; it depends in part on the thickness of the parent salt layer (the Louann Salt), the amount of this salt that is mobilized, and the thickness of overlying sediments that have been pierced. Heights of 3,000-6,000 $\mathrm{m}$ are not uncommon. Many domes flare outward at depth and may be connected at the base with the parent salt layer. Other domes, which are more constricted at depth and may be pinched off at the base and disconnected from the parent layer, give the appearance of an inverted teardrop in cross section.

The theory most widely accepted on the origin of cap rock is that it represents a residue of anhydrite and 
other insoluble minerals that accumulate at the upper surface as the salt dome rises through water-bearing sediments and is dissolved (Goldman, 1933; Taylor, 1937, 1938; Murray, 1966, 1968) (fig. 2.23). The anhydrite crystals, which make up about 99 percent of the water-insoluble residue in a dome salt (Gera, 1972; Walker, 1974), are then recrystallized and compacted to form a massive cap rock; this may locally be hydrated to form gypsum. The calcite and sulfur commonly present in cap rock are secondary; they result from the reduction of anhydrite by sulfate-reducing bacteria (Feely and Kulp, 1957; Jensen, 1968). Walker (1974) pointed out that because of a number of cap rock features this theory should be modified. He postulated that most of the anhydrite was precipitated when ascending waters, having dissolved calcium sulfate and salt on the flanks of the dome, found geochemical conditions that were favorable for precipitation at the top of the dome.

Walker (1974) studied cap rock on 39 salt domes in the Gulf Coast basin (fig. 2.24), and summarized a great deal of data on cap-rock lithology from wells drilled on 24 of these domes (table 2.2). These data do not represent all the domes in the basin with cap rock, because Hawkins and Jirik (1966) reported that 181 domes are known to have cap rock. However, the compilation by Walker (1974), which is representative of cap rock at depths less than $1,200 \mathrm{~m}$, is an excellent guide to the general character, thickness, and depth of anhydrite on salt domes.

Cap rock is an irregular complex of rocks and minerals formed on the top of about half the domes in the Gulf Coast basin. Both shallow and deep domes have cap rock, but it is more likely to be present, and thickest, over the shallower domes (Walker, 1974). The ideal or mature sequence of rocks that form cap rock would be, in decending order, calcite-gypsum-anhydrite-salt (Murray, $1966,1968)$. In his study of cap rock on 24 shallow domes (table 2.2), Walker (1974) found this complete sequence in only 22 percent of the 94 wells examined, and found a variety of lithologic scquences in the remaining wells (fig. 2.25). Other common decending sequences include calcite-gypsum-salt (33 percent), calcite-anhydrite-salt (16 percent), calcite-salt (16 percent), and gypsumanhydrite-salt (4 percent).

Cap rock not only is variable in lithologic sequence from dome to dome, but also can be variable between boreholes on a single dome. The anhydrite part of the cap rock, which is generally the thickest, is followed in thickness by calcite, gypsum, and celestite (Walker, 1974). Interbeds of salt and (or) clastic sediments also may be present. Salt domes with thicknesses of cap rock greater than $100 \mathrm{~m}$ are common (Murray, 1961, 1966).

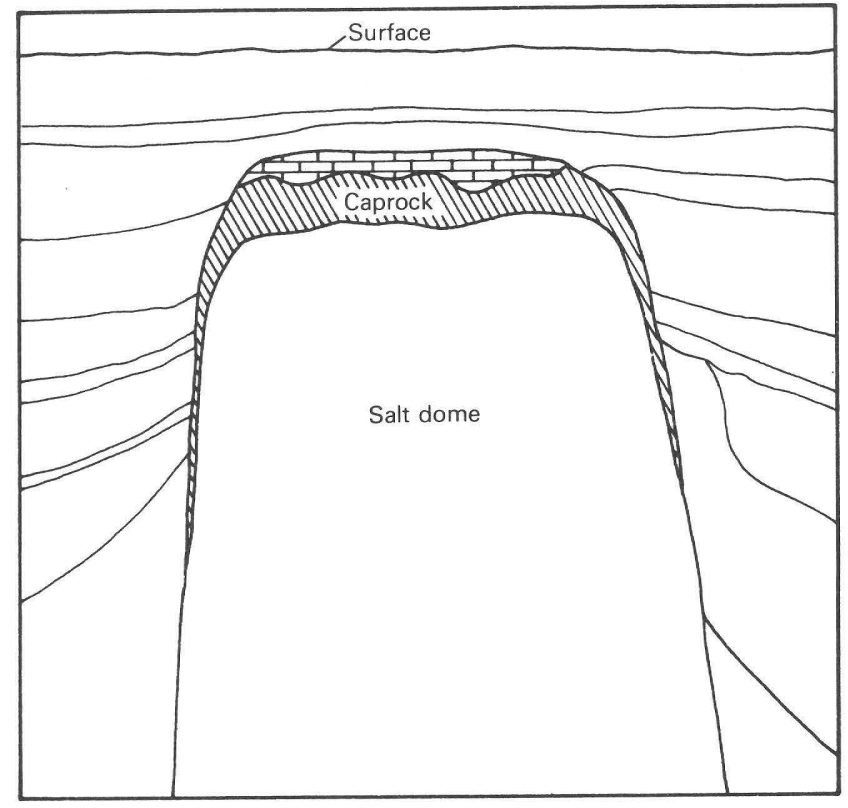

Figure 2.23. Idealized section of salt dome showing development of gypsum and (or) anhydrite cap rock at the top and along part of the sides (modified from Walker, 1974). Calcite (block pattern) is above the gypsum and (or) anhydrite.

Anhydrite has an average thickness of about $67 \mathrm{~m}$ in cap rock on the domes listed in table 2.2 , but the thickness generally ranges from about $25-240 \mathrm{~m}$ on different domes, and can vary considerably on the same dome (Walker, 1974). Anhydrite is most common in the lower part of the cap rock, but it is not restricted to that position. Salt in the Gulf Coast basin contains an average of about 3 percent anhydrite (Kupfer, 1963). Therefore, dissolution of about $8 \mathrm{~km}$ of this salt would be needed to form $240 \mathrm{~m}$ of cap-rock anhydrite.

The depth to the top of cap rock ranges from zero (Gyp Hill dome at Falfurrias, Tex.) to many thousands of meters. Of the domes listed in table 2.2, the depth to the top of cap rock ranges from 30 to $1,095 \mathrm{~m}$ and averages about $350 \mathrm{~m}$; the depth to the top of anhydrite ranges from about 100 to $1,140 \mathrm{~m}$ and averages about $430 \mathrm{~m}$.

Anhydrite in cap rock typically consists of an interlocking mosaic of crystals, $0.05-2.1 \mathrm{~mm}$ in size, that have a low porosity and a slight preferred orientation in the horizontal direction. Minerals commonly dispersed in the anhydrite include trace amounts of calcite, dolomite, quartz, pyrite, sulfur, barite, and celestite (Walker, 1974). Generally, the contact between anhydrite cap rock and underlying salt is gradational; the salt grades upward 


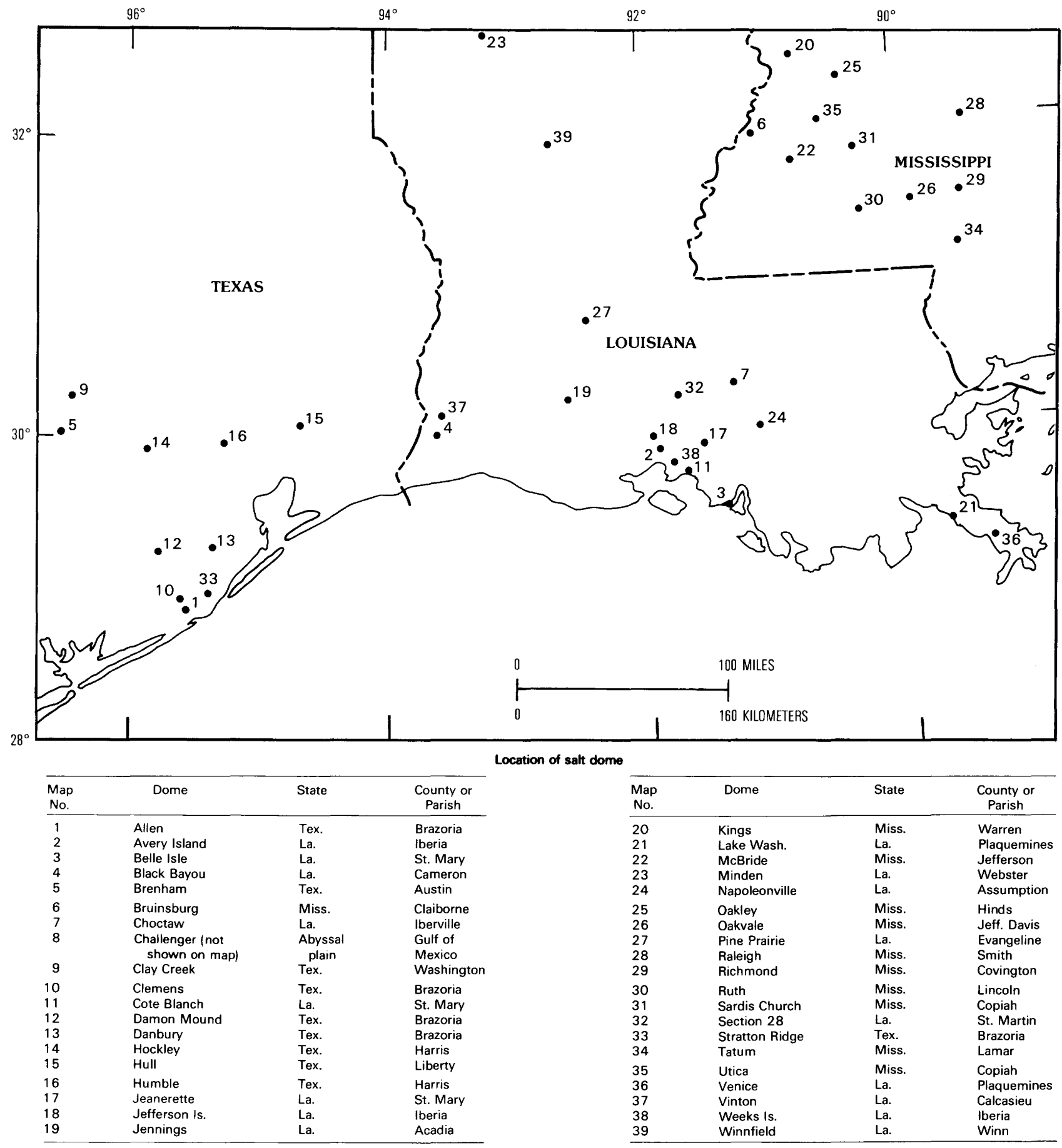

Figure 2.24. Salt domes of the Gulf Coast basin for which cap-rock data are available (compiled from Walker, 1974).

into a zone of friable anhydrite sand, which in turn grades into compact anhydrite cap rock.

The upper part of the cap rock on most domes is highly fractured and brecciated; brecciation generally decreases downward toward the salt (Walker, 1974).
These features generally have been attributed to the pressure exerted on the cap rock during upward movement of the salt diapir. The calcite part of the cap rock commonly is highly cavernous, and may have a porosity of as much as 50 percent; most of the 
Table 2.2. Depth and thickness, in feet, of various rock types in cap rock of selected salt domes in the Gulf Coast basin (modified from Walker, 1974)

[Depth to top is feet below surface. Leaders (--) indicate none of the lithology recovered. *indicates value from published data. Thickness data for each lithology are averages from all wells drilled on each dome]

\begin{tabular}{|c|c|c|c|c|c|c|c|c|c|}
\hline \multirow[b]{2}{*}{ Dome } & \multicolumn{2}{|c|}{$\begin{array}{l}\text { Depth } \\
\text { (in feet) } \\
\text { to top }\end{array}$} & \multicolumn{4}{|c|}{ Thickness (in feet) } & \multicolumn{2}{|r|}{ Rat1o } & \multirow[b]{2}{*}{$\begin{array}{l}\text { No. of } \\
\text { wells }\end{array}$} \\
\hline & $\begin{array}{l}\text { Cap } \\
\text { rock }\end{array}$ & Salt & Carbonate & Gypsum & Anhydrite & $\begin{array}{c}\text { Total } \\
\text { sulfate }\end{array}$ & $\begin{array}{l}\text { Sulfate: } \\
\text { carbonate }\end{array}$ & $\begin{array}{l}\text { Anhydrite: } \\
\text { gypsum }\end{array}$ & \\
\hline $\begin{array}{l}\text { Allen, Tex. } \\
\text { Belle Isle, La.- } \\
\text { Black Bayou, La.- } \\
\text { Brenham, Tex.- } \\
\text { Damon Mound, Tex.- }\end{array}$ & $\begin{array}{r}995 \\
-\quad 859 \\
-\quad 1054 \\
-\quad 1523 \\
-\quad 220\end{array}$ & $\begin{array}{l}1394 \\
1199 \\
2000 * \\
2253 \\
562\end{array}$ & $\begin{array}{r}51 \\
283 \\
76.3 \\
74.8 \\
131.9\end{array}$ & $\begin{array}{c}246.7 \\
120.3 \\
66 \\
278.9\end{array}$ & $\begin{array}{c}166.3 \\
10^{*} \\
800^{*} \\
363 \\
\end{array}$ & $\begin{array}{l}413.0 \\
130.3 \\
866 \\
363 \\
278.9\end{array}$ & $\begin{array}{r}8.10 \\
.46 \\
11.43 \\
4.85 \\
2.11\end{array}$ & $\begin{array}{r}0.67 \\
.08 \\
12.12 \\
-- \\
--\end{array}$ & $\begin{array}{r}15 \\
7 \\
7 \\
7 \\
28\end{array}$ \\
\hline $\begin{array}{l}\text { Hockley, Tex. } \\
\text { Hul1, Tex. }\end{array}$ & $\begin{array}{r}452 \\
-\quad 418\end{array}$ & $\begin{array}{r}1124 \\
787\end{array}$ & $\begin{array}{r}128.2 \\
72.5\end{array}$ & $\begin{array}{l}110.7 \\
222.5\end{array}$ & $\begin{array}{r}419 \\
86.8\end{array}$ & $\begin{array}{c}529.7 \\
312\end{array}$ & $\begin{array}{l}4.13 \\
4.30\end{array}$ & $\begin{array}{r}3.79 \\
.39\end{array}$ & $\begin{array}{l}4 \\
7\end{array}$ \\
\hline $\begin{array}{l}\text { Humble, Tex. } \\
\text { Kings, Miss. } \\
\text { McBride, Miss }\end{array}$ & $\begin{array}{r}1181 \\
-\quad 3593 \\
-2095\end{array}$ & $\begin{array}{l}1307 \\
3845 \\
2190\end{array}$ & $\begin{array}{l}60.2 \\
155 \\
95.5\end{array}$ & 22 & $\begin{array}{l}66.2 \\
75 \\
-\end{array}$ & $\begin{array}{l}66.2 \\
97 \\
\end{array}$ & $\begin{array}{r}1.10 \\
.62 \\
-\end{array}$ & 3.41 & $\begin{array}{l}5 \\
1 \\
4\end{array}$ \\
\hline $\begin{array}{l}\text { Minden, La.- } \\
\text { Napoleonville, La.- } \\
\text { Oakvale, Miss. } \\
\text { Pine Prairie, La.- } \\
\text { Richmond, Miss.- }\end{array}$ & $\begin{array}{r}1175 \\
-\quad 580 \\
-\quad 1648 \\
-\quad 173 \\
-\quad 1717\end{array}$ & $\begin{array}{r}1905 * \\
773 \\
2396 \\
530 \\
1950\end{array}$ & $\begin{array}{c}144 \\
104.7 \\
94.6 \\
169.3 \\
34\end{array}$ & $\begin{array}{l}11 \overline{3.5} \\
157.8 \\
20\end{array}$ & $\begin{array}{l}586 \\
27.5 \\
702 \\
18.8 \\
196.5\end{array}$ & $\begin{array}{l}586 \\
141 \\
702 \\
176.6 \\
216.5\end{array}$ & $\begin{array}{l}4.07 \\
1.35 \\
7.42 \\
1.04 \\
6.37\end{array}$ & $\frac{.}{.24} \frac{.12}{9.83}$ & $\begin{array}{r}2 \\
10 \\
7 \\
12 \\
3\end{array}$ \\
\hline $\begin{array}{l}\text { Ruth, Miss. } \\
\text { Sardis Church, Miss. }\end{array}$ & $\begin{array}{r}2331 \\
-1210\end{array}$ & $\begin{array}{l}2700^{*} \\
2300^{*}\end{array}$ & $\begin{array}{l}402.2 \\
667\end{array}$ & $\overline{23 *}$ & $\begin{array}{r}37 * \\
400 *\end{array}$ & $\begin{array}{r}37 \\
423\end{array}$ & $\begin{array}{l}.09 \\
.63\end{array}$ & $\overline{17.39}$ & $\begin{array}{l}4 \\
8\end{array}$ \\
\hline $\begin{array}{l}\text { Section } 28 \text {, La.- } \\
\text { Stratton Ridge, Tex. } \\
\text { Tatum, Miss. }\end{array}$ & $\begin{array}{r}1753 \\
-1391 \\
-\quad 1134\end{array}$ & $\begin{array}{l}1785 \\
1633 \\
1520\end{array}$ & $\begin{array}{l}20 \\
133.7 \\
108.2\end{array}$ & $\begin{array}{l}108.6 \\
35\end{array}$ & $\begin{array}{r}131.7 \\
194.2\end{array}$ & $\begin{array}{l}24 \overline{0.3} \\
229.2\end{array}$ & $\begin{array}{l}-- \\
1.80 \\
2.12\end{array}$ & $\begin{array}{l}-- \\
1.21 \\
5.55\end{array}$ & $\begin{array}{l}2 \\
8 \\
9\end{array}$ \\
\hline $\begin{array}{l}\text { Utica, Miss. } \\
\text { Venice, La. } \\
\text { Vinton, La. } \\
\text { Winnfield, La. }\end{array}$ & $\begin{array}{r}2641 \\
-\quad 1875 \\
-\quad 528 \\
-\quad 100\end{array}$ & $\begin{array}{c}3135 \\
3000 * \\
968 \\
460\end{array}$ & $\begin{array}{l}494 \\
381.5 \\
104 \\
160\end{array}$ & $\begin{array}{c}-\bar{C} \\
60\end{array}$ & $\begin{array}{c}74 * \\
83 \\
140\end{array}$ & $\begin{array}{l}744 \\
315 \\
200\end{array}$ & $\begin{array}{l}-\overline{1.95} \\
3.03 \\
1.25\end{array}$ & $\begin{array}{l}-\overline{-} \\
.36 \\
2.33\end{array}$ & $\begin{array}{l}1 \\
6 \\
5 \\
4\end{array}$ \\
\hline
\end{tabular}

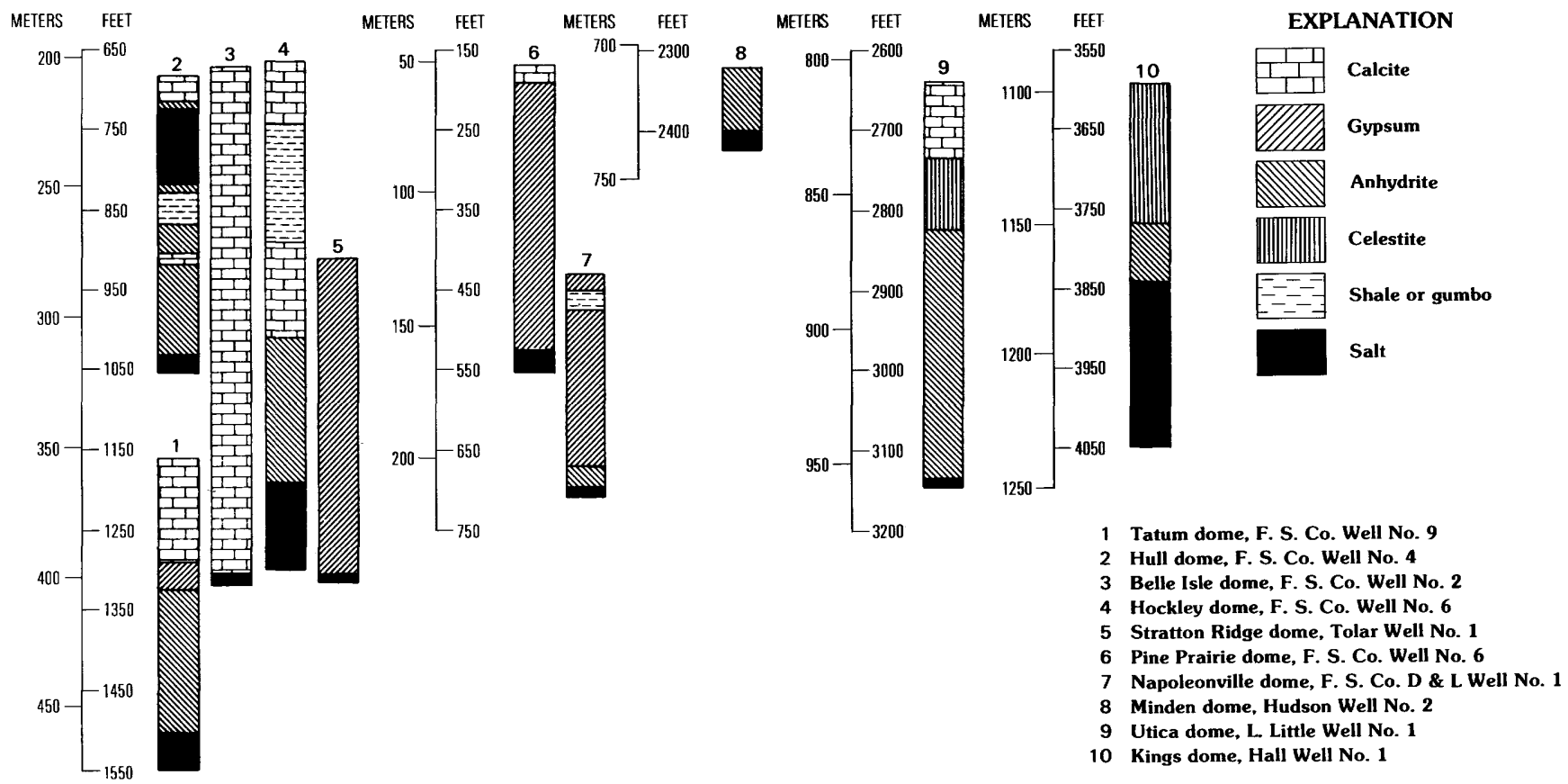

Figure 2.25. Columnar sections showing lithologic variability of cap rock among 10 salt domes (modified from Walker, 1974). 


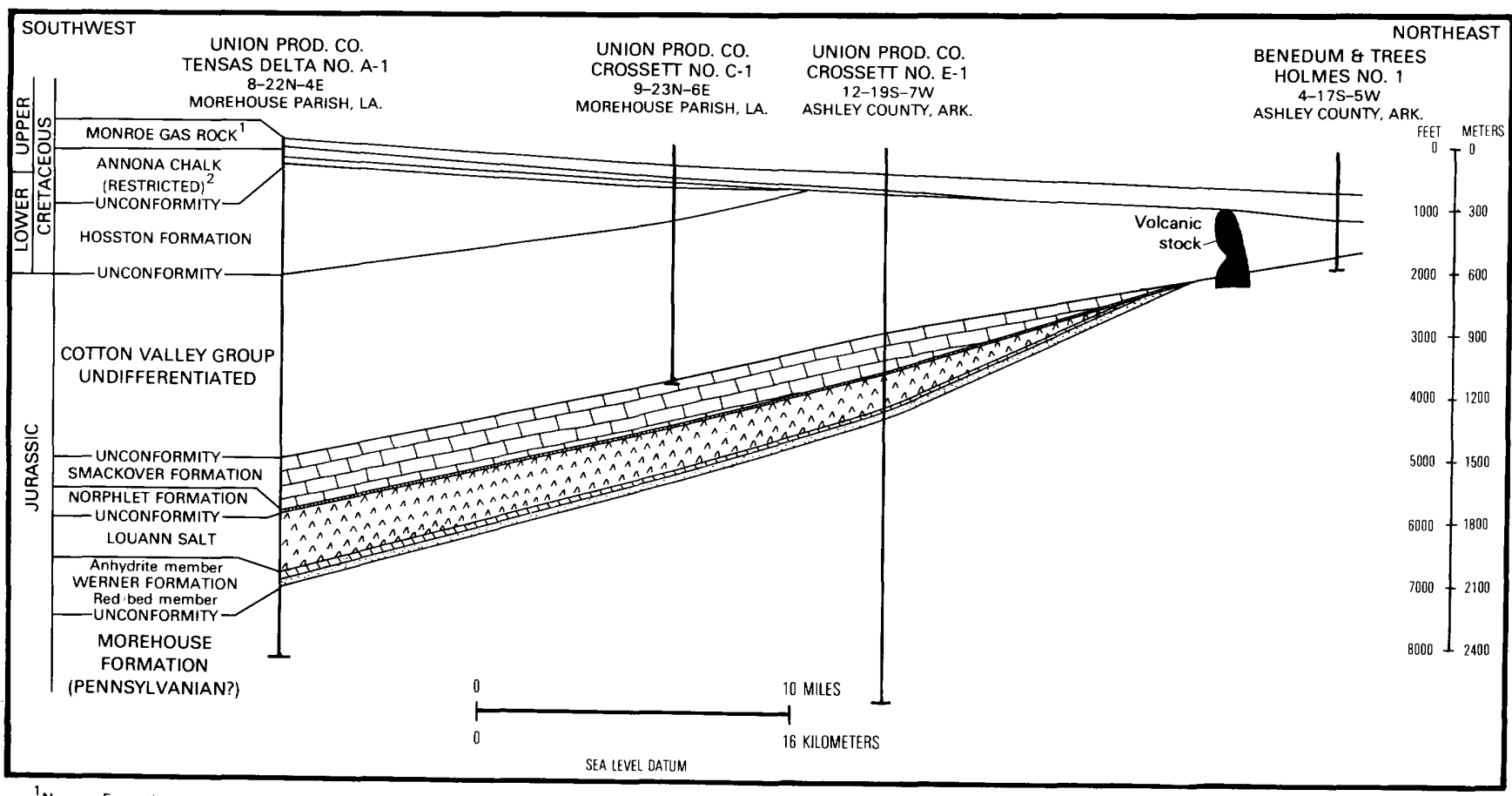

${ }_{2}^{1}$ Navarro Formation

${ }^{2}$ Tongue of Austin Chalk

Figure 2.26. Cross section showing Werner Formation and overlying strata in southeastern Arkansas and northeastern Louisiana (modified from Hazzard and others, 1947).

hydrocarbons and sulfur found in cap rock are contained in these cavities. The cap rock in many domes also contains large amounts of ground water in its pore spaces.

In summary, cap rock on many of the salt domes in Texas, Louisiana, and Mississippi contains thick masses of anhydrite at moderate depths. However, the thickness and character of anhydrite and other rock types in the cap rock vary considerably, and the upper part of the sequence on most domes is highly fractured, brecciated, and water bearing. Furthermore, because some of the domes in the coastal areas of the Gulf of Mexico appear to be tectonically active, the cap rock on these domes is moving closer to the land surface.

\section{Werner Formation}

The Werner Formation is a widespread anhydrite unit of Middle Jurassic age that underlies the Louann Salt of Middle and Late Jurassic age in the western and central part of the Gulf Coast basin (fig. 2.20). The anhydrite member of the formation is typically $15-30 \mathrm{~m}$ thick, and its depth ranges from about $1,000 \mathrm{~m}$ on the north to more than 3,000 m toward the Gulf of Mexico. The unit has been penetrated by few boreholes, and thus few data are available on it. The main references on anhydrite in the Werner Formation are Imlay (1943), Hazzard and others (1947), and Newkirk (1971).

The Werner Formation consists of a lower, red-bed clastic member that grades upward into a relatively pure anhydrite member, which appears to be conformable with the overlying Louann Salt. The Werner Formation represents the first stage in a long period of evaporite deposition in the Gulf Coast basin; its distribution is believed to be similar to that of the Louann Salt but to extend farther updip (Newkirk, 1971). The unit underlies parts of southern Arkansas, northeastern Texas, northern Louisiana, Mississippi, and southwestern Alabama. Total thickness of the Werner Formation is commonly 30-60 m. The northern limit of the Werner in Arkansas is erosional and results from truncation by the Upper Jurassic Norphlet Formation.

The depth to the Werner is as shallow as $1,000-2,000 \mathrm{~m}$ in parts of southern Arkansas (fig. 2.26) and adjacent areas of west-central Mississippi and the northeast corner of Texas. From this region the Werner dips down into the Gulf Coast basin. It is 2,000-3,000 m deep across northern Louisiana, and is at even greater depths farther south and at most other locations in the basin.

The anhydrite member is $\mathbf{1 5 - 3 0 ~ m ~ t h i c k ~ i n ~ m o s t ~}$ parts of southern Arkansas, where cores show that the rock has a medium-grained, dense granular texture; it is 
clear to milky white and tinged with pink (Hazzard and others, 1947). The rock lacks either a calcareous or clay matrix. Descriptions of samples from several wells indicate that anhydrite probably is interbedded with dolomite or limestone in the basal few meters of the member (Hazzard and others, 1947).

Therefore, the Werner anhydrite may be as much as $30 \mathrm{~m}$ thick and may occur at moderate depths near its updip limit in southern Arkansas and adjacent States. More data are needed to verify this thickness and depth, and to establish whether the anhydrite is a single bed or is an interbedded sequence of anhydrite and other strata.

\section{Buckner Formation}

The Buckner Formation (Upper Jurassic) is a widespread evaporite and clastic unit in the western and central part of the Gulf Coast basin (fig. 2.20). The unit ranges from 30 to $200 \mathrm{~m}$ in thickness and consists chiefly of anhydrite and clastics. Individual anhydrite beds may be as much as $60 \mathrm{~m}$ thick, and they are less than $1,500 \mathrm{~m}$ beneath land surface in several counties of southern Arkansas. Principal references on anhydrite in the Buckner Formation are Imlay (1943), Swain (1949),
Oxley and others (1967), Dickinson (1968a, 1968b), Akin and Graves (1969), and Newkirk (1971).

The Buckner Formation is a lagoonal deposit of evaporites interbedded with clastics, carbonates, and minor salt. Equivalent in part to a part of the underlying Smackover Formation, the Buckner also is equivalent to the lower part of the overlying Haynesville Formation.

The Buckner Formation is characterized by anhydrite and red beds over much of the northern Gulf Coast basin, but it grades southward into marine shales. Thus the anhydrite-red bed sequence predominates in a belt 75-100 km wide along the northern margin of the basin. Nonanhydritic strata equivalent to the Buckner are recognized over much of the basin, and these also are generally referred to as Buckner.

Strata of the Buckner Formation are deep beneath the land surface in most parts of the basin; they are as shallow as 1,000-1,500 m only in southern Arkansas. In northeastern Texas the Buckmer Formation is as shallow as $1,500-1,800 \mathrm{~m}$ (Swain, 1949), whereas in Louisiana and Mississippi it is generally 2,000-3,000 $\mathrm{m}$ deep at its updip margin. From all these areas, the Buckner and equivalent strata dip toward the Gulf of Mexico where they occur at depths in excess of $5,000 \mathrm{~m}$.

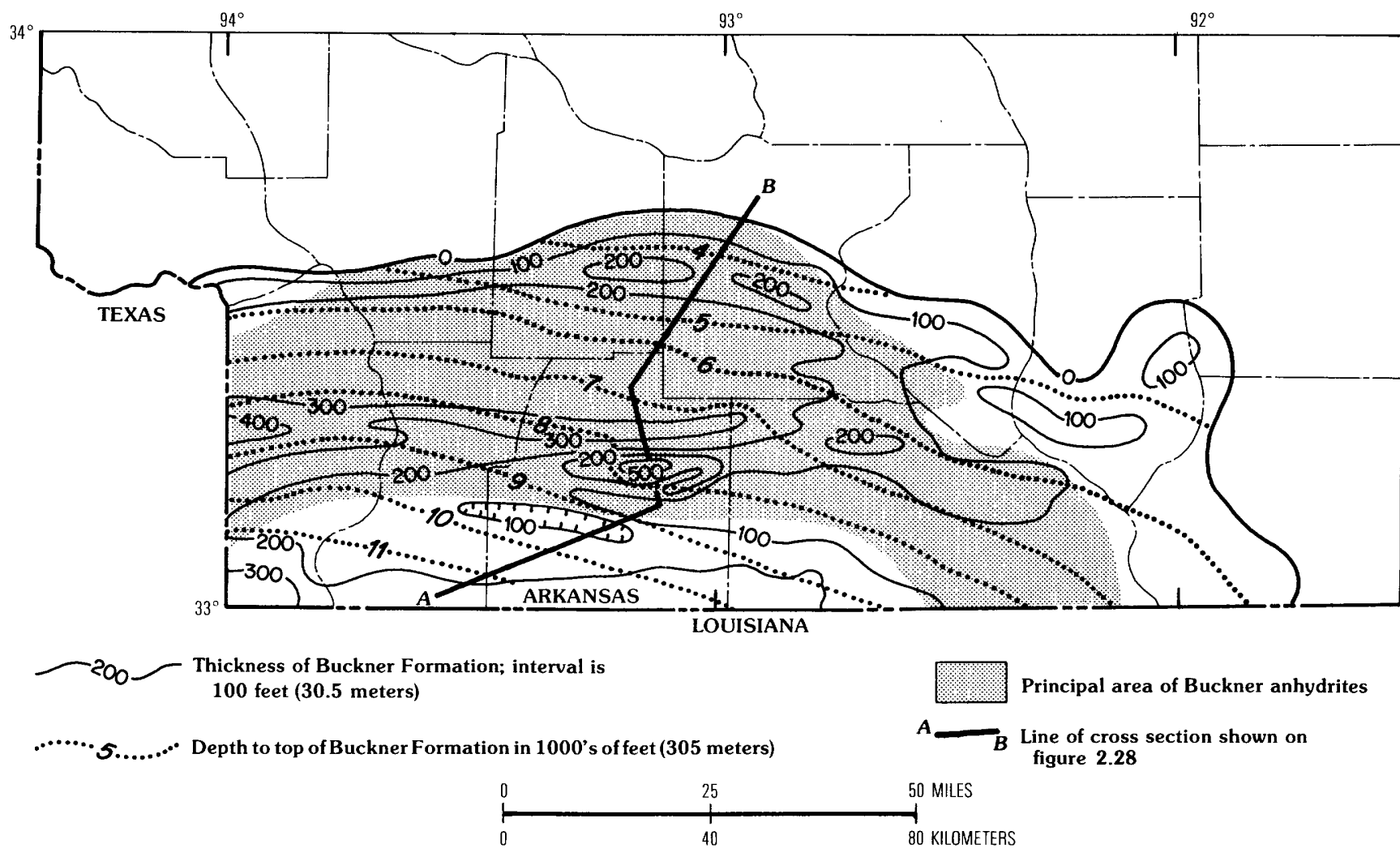

Figure 2.27. Map showing thickness, in feet, and depth below land surface to top of anhydrites in Buckner Formation in southern Arkansas. Based on data from Akin and Graves (1969). 


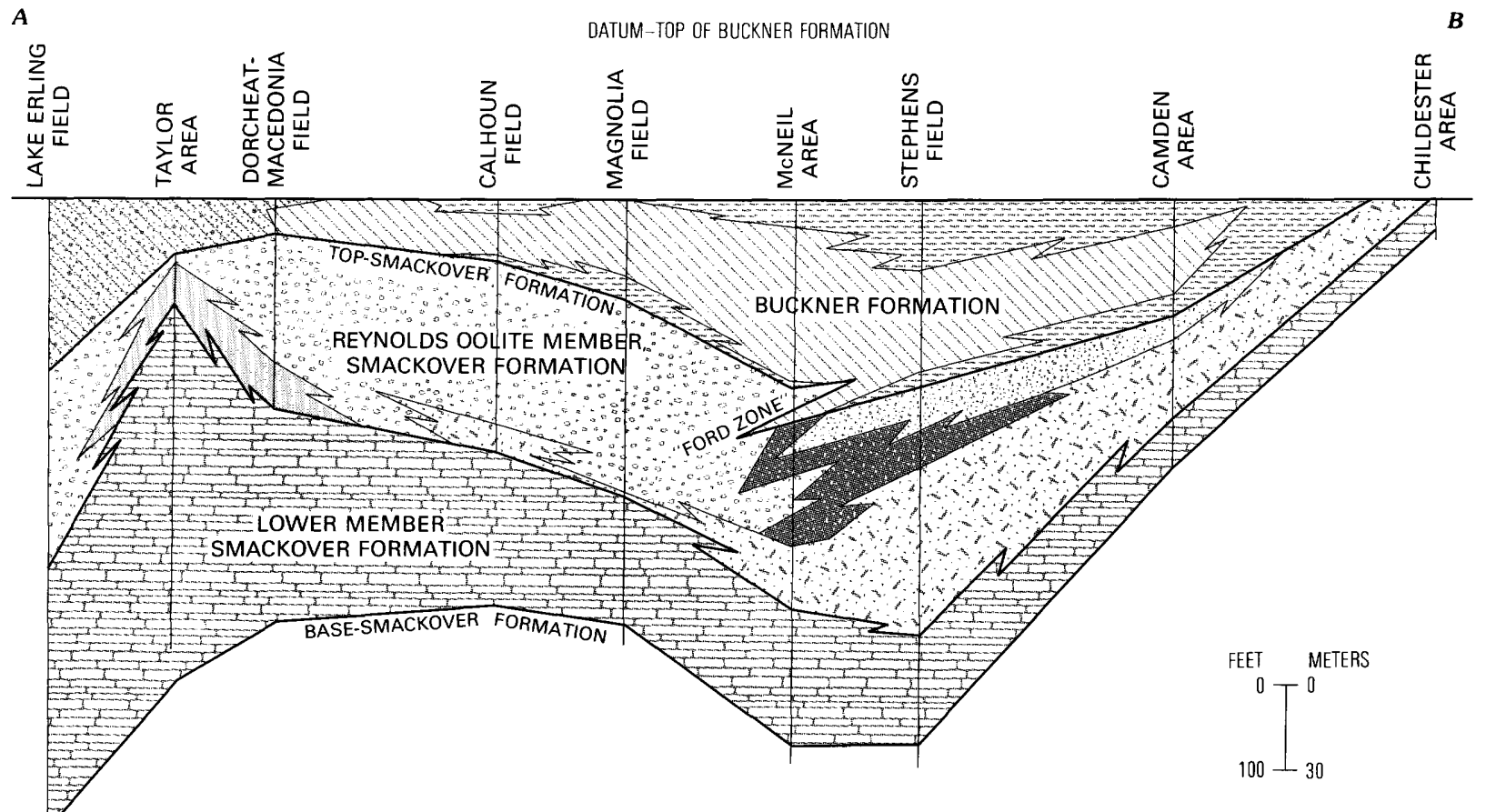

EXPLANATION

Nonmarine shale
Anhydrite
Anhydritic sandstone
and shale
Calcarenite-carbonate
mudstone facies

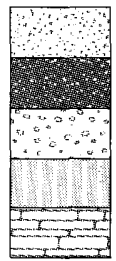

Modified grapestone facies

Grapestone facies

Oolite facies

Interbedded facies

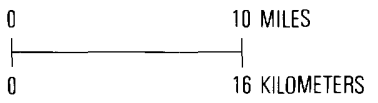

Shaly to dense limestone

Figure 2.28. North-south stratigraphic cross section ( $A-B$ in fig. 2.27) showing Buckner and Smackover Formations in southern Arkansas (modified from Akin and Graves, 1969).

The thickness of the Buckner Formation increases southward toward the Gulf of Mexico in all areas. It ranges from a few meters thick around the perimeter of the basin to several hundred meters thick at depths of several thousand meters. In places, the Buckner Formation is combined with the overlying anhydritic Haynesville Formation into a sequence of anhydrite interbeds as much as $500 \mathrm{~m}$ thick (Oxley and others, 1967).

The only area of anhydrite-bearing Buckner strata at moderate depths is in parts of Hempstead, Nevada, Ouachita, and Calhoun Counties of southern Arkansas (fig. 2.27). In this area, the top of the Buckner ranges from about 1,000-1,500 $\mathrm{m}$ below the surface and consists chiefly of anhydrite. Total thickness of the Buckner is $30-60 \mathrm{~m}$ in much of this area of southern Arkansas, and locally it may be slightly more than $60 \mathrm{~m}$ thick.

The anhydrite facies in the Buckner Formation of Arkansas (fig. 2.27) was deposited north of a barrier that restricted normal flow of marine water from the open ocean to the south (Akin and Graves, 1969). This barrier was a chain of east-west-trending structures. Within the evaporite basin to the north, the Buckner consists of dolomite at the base, nodular anhydrite in the middle, and nonmarine red shale at the top (fig. 2.28). Detailed information is not readily available on the thickness of the anhydrite zone in the middle of the formation nor on the thickness of the individual anhydrite beds within this zone, but figure 2.28 indicates the overall thickness of the anhydrite zone.

The Buckner is considerably thinner over the crests of structural highs developed on the underlying Smackover Formation and is generally much thicker in the structurally low areas (Akin and Graves, 1969). Most of these variations in thickness result from original deposition of abnormally thick or thin beds of anhydrite; thus, thick anhydrite beds in this area are most likely to occur in the structural lows as mapped on the Smackover. 


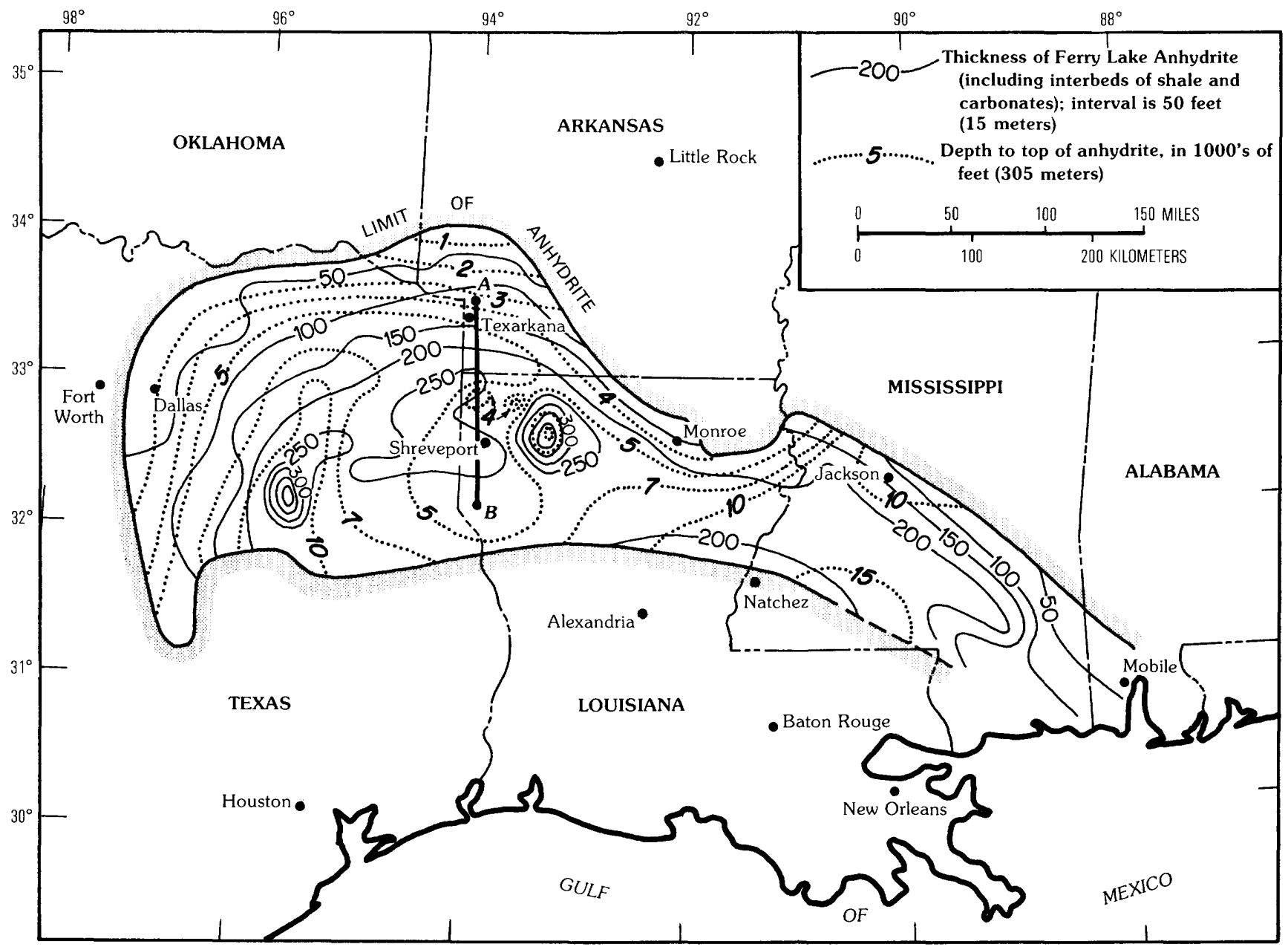

Figure 2.29. Map showing thickness, in feet, and depth below land surface to top of Ferry Lake Anhydrite in Gulf Coast area. Ferry Lake consists of anhydrite interbedded with shale and carbonate. Based on data from Forgotson (1958, 1963) and Hickey (1972). Cross section $A-B$ shown in figure 2.30 .

\section{Ferry Lake Anhydrite}

The Ferry Lake Anhydrite, the only widespread evaporite deposit in the Lower Cretaceous of the Gulf Coast, is easily recognized on mechanical logs and in well samples. The unit is in the middle part of the Trinity Group and extends in the subsurface from eastern Texas to southwestern Alabama (fig. 2.20). Thickness of the Ferry Lake ranges from $15 \mathrm{~m}$ to about $120 \mathrm{~m}$; the formation consists of individual anhydrite beds, each $10 \mathrm{~m}$ to perhaps as much as $30 \mathrm{~m}$ thick, that are interbedded with black shale and carbonate. The depth to the top of anhydrite ranges from less than $300 \mathrm{~m}$ in the northwestern part of the Gulf Coast basin to more than 3,000 $\mathrm{m}$ farther south toward the Gulf. Principal summary references are Shreveport Geological Society (1947), Forgotson (1957, 1958, 1963), McNamee (1969), and Rainwater (1970b, 1971a).
The Ferry Lake Anhydrite was deposited in a broad belt that extends across the central part of the Gulf Coast region (fig. 2.29). The unit was laid down on a shallow-marine shelf that had limited connection with the open ocean and that had a small influx of clastic sediment. The seaward (southern) limit of anhydrite may coincide with an extensive barrier reef that probably was growing at the edge of a carbonate shelf (Rainwater, 1971a). Ferry Lake strata are characteristically lenticular, but some individual beds can be correlated over moderate distances (Rainwater, 1970b). Unequal rates of subsidence caused abnormally thick accumulations of anhydrite in depressions, whereas carbonates were deposited on the higher parts of the region.

The Ferry Lake is composed of white to gray nodular anhydrite that is interbedded with dark-gray to black shale and lesser amounts of dolomite and limestone. Individual anhydrite beds in many places 


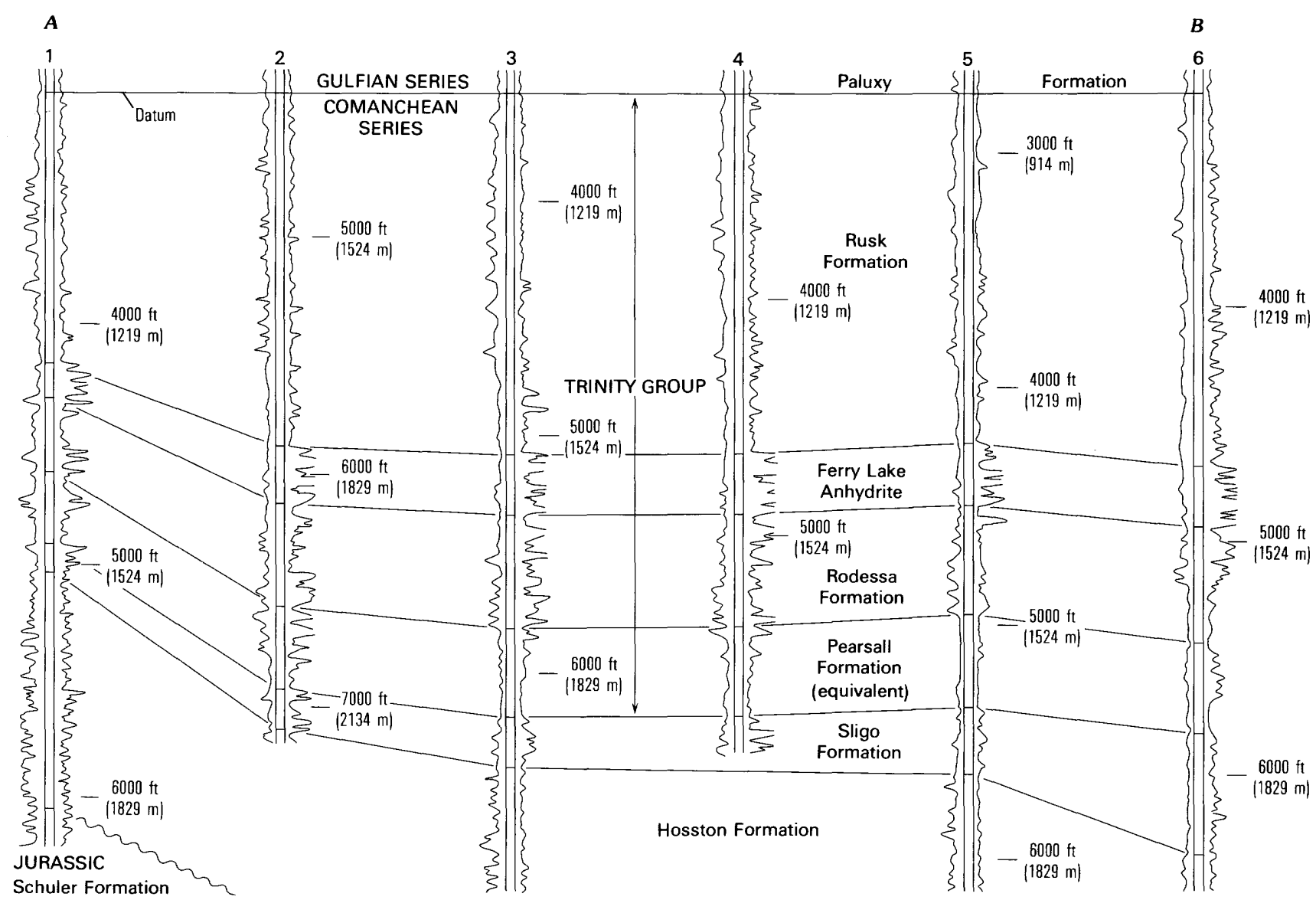

LIST OF WELLS

1. Delta Drilling Co. Dildy-Johns No. 1; Miller Co., Ark., sec. 4 T. 16 S., R. $28 \mathrm{~W}$.

2. James G. Brown L. O. Davis No. 1; Miller Co., Ark., sec. 7 T. 19 S. R. $27 \mathrm{~W}$

3. Union Producing Co. Caddo Levee Brd. No. B-1; Caddo Ph., La., sec. 26, T. 23 N., R. 16 W.
4. Ohio Oil Co. Williams No. 1; Caddo Ph., La., sec.3, T. 22 N., R. 15 W.

5. Gulf Refining Co. Levee Brd. N Lease No. 280; Caddo Ph., La., sec. 20 , T. 20 N., R. 16 W.

6. Texas Co. J. C. Williams, Jr. No. 1; Caddo Ph., La., sec. 2 T. 15 N., R. $15 \mathrm{~W}$

Figure 2.30. North-south stratigraphic cross section showing the Ferry Lake Anhydrite and other units of the Lower Cretaceous Trinity Group in Caddo Parish, northwestern Louisiana, and Miller County, southwestern Arkansas (modified from Forgotson, 1958). Horizontal distances not to scale. Line of cross section $A-B$ shown in figure 2.29.

grade laterally into carbonates. Halite is not associated with the Ferry Lake Anhydrite at any place in the basin.

Anhydrite beds in the Ferry Lake typically are 3-10 $\mathrm{m}$ thick in most parts of the Gulf Coast basin, but in some areas they exceed $15 \mathrm{~m}$ and may reach as much as $30 \mathrm{~m}$ in thickness. The thicker individual beds occur in northern Louisiana and in nearby areas of southwestern Arkansas and eastern Texas (fig. 2.30).

Total thickness of the Ferry Lake Anhydrite typically is $15-60 \mathrm{~m}$ in most parts of the Gulf Coast basin (fig. 2.29). In some areas of northwestern Louisiana and eastern Texas, the unit is $75 \mathrm{~m}$ to more than $120 \mathrm{~m}$ thick. These areas include the Sabine uplift (Shreveport area) along the Louisiana-Texas State line, sites of maximum thicknesses in Webster Parish, La., and in Henderson and Anderson Counties, Tex. The top of the Ferry Lake Anhydrite is shallowest in the northern part of the basin where it is $300-1,500 \mathrm{~m}$ below the surface in southwestern Arkansas and parts of adjacent States (fig. 2.29). It is typically $1,200-1,500 \mathrm{~m}$ below the surface over the Sabine uplift. From these areas the Ferry Lake dips southward toward the Gulf of Mexico; it is 3,000-4,000 m deep in much of the southern part of the Gulf Coast basin.

The Ferry Lake Anhydrite thins northward across southwestern Arkansas to become a sequence of limestone and anhydrite about $5 \mathrm{~m}$ thick near its updip depositional limit. Farther north, the limestone and anhydrite grade into gray shale and sandstone. At and near the outcrop in this area the thin anhydrite beds have been 
altered to gypsum that is now being quarried. The northern limit of the Ferry Lake is an erosional feature across southeast Arkansas and northeast Louisiana (fig. 2.29).

In summary, the Ferry Lake appears to contain one or several anhydrite beds as much as $30 \mathrm{~m}$ thick at depths of $300-1,500 \mathrm{~m}$ in the northern part of the Gulf Coast basin. Two large areas where this may occur are in southwestern Arkansas and parts of adjacent states and over the Sabine uplift. Strata in these areas are essentially horizontal, but locally they are faulted.

\section{CENTRAL TEXAS REGION-EDWARDS LIMESTONE AND MCKNIGHT FORMATION}

Lower Cretaceous strata of central and southcentral Texas contain evaporites in two separate but related basins (fig. 2.1). Outcrops of the Edwards Limestone have interbeds of gypsum that were deposited in the Kirschberg lagoon, an Early Cretaceous feature in the central part of the State, whereas outcrops of the equivalent McKnight Formation contain anhydrite interbeds that had been deposited farther south in the Maverick basin. Individual beds of gypsum and anhydrite are $10-15 \mathrm{~m}$ thick and range in depth from zero to about $2,500 \mathrm{~m}$. References to evaporites in both areas include those of Barnes (1943), Winter (1962), Fisher and Rodda (1969), Rose (1972), and Bay (1977).

Outcrops of nodular gypsum in the Kirschberg Evaporite Member of the Fort Terrett Formation (Edwards Group of Rose, 1972) are limited to small areas in Gillespie and Menard Counties, Tex. The sulfate unit at one time must have been a continuous bed that extended throughout a number of counties that make up the Kirschberg lagoon (Fisher and Rodda, 1969), but most of the unit is now dissolved; in its place is a widespread zone of brecciated rock that formed by collapse of overlying limestone and dolomite. Anhydrite has not been identified in this unit anywhere in the area. Total thickness of the Kirschberg Evaporite Member ranges from 12 to $25 \mathrm{~m}$, and the remnant gypsum bed is typically $2-11 \mathrm{~m}$ thick. About $8 \mathrm{~m}$ of gypsum is being quarried near Fredericksburg in Gillespie County.

The Maverick basin, located partly in Maverick, Zavala, and Dimmit Counties, Tex., contains about 30-120 m of anhydritic strata that make up the McKnight Formation. The formation was divided by Winter (1962) into lower and upper members of shaly limestone that are separated by a middle member of black shale; all three members contain anhydrite beds that are thin, perhaps as much as $10-15 \mathrm{~m}$ thick. The top of the McKnight Formation is as little as several hundred meters beneath the surface in the northwestern part of the basin and about $2,500 \mathrm{~m}$ beneath the surface in the southeastern part of the basin.

\section{PERMIAN BASIN}

\section{Structure and Geologic Framework}

The Permian basin is not a single structural basin, but a large region of the Southwestern United States in which salt, anhydrite, and other evaporites of Permian age were deposited along with red beds and carbonates. The five principal structural basins in the region are named the Delaware, Midland, Palo Duro, Anadarko, and Dalhart basins (fig. 2.31). The Permian basin, which is in the southwestern part of the tectonically stable interior of North America, is characterized by nearly flat-lying Permian and younger sedimentary rocks that are faulted at only a few places. Strata dip gently into each of the structural basins from adjacent arches and uplifts at a rate of $2-10 \mathrm{~m} / \mathrm{km}\left(0.1^{\circ}-0.5^{\circ}\right)$.

After a long period of tectonic stability, during which a thick sequence of lower and middle Paleozoic carbonates were deposited, much tectonic activity occurred in the area of the Permian evaporite basin during Pennsylvanian time. A series of pronounced uplifts and arches were created, and adjacent areas subsided to receive thick accumulations of Pennsylvanian and Permian sediments. This period of tectonism was followed by stabilization of the region before the Permian evaporites were deposited.

During Permian time, a broad and shallow inland sea covered much of the Southwestern United States; it extended northward from West Texas into northwestern Kansas. Because of slow but continual subsidence beneath all parts of this inland sea, a thick sequence of red beds and evaporites (dolomite, anhydrite, and salt) was deposited within and north of the Delaware and Midland basins.

Normal-marine water entered the Delaware and Midland basins from the open ocean to the southwest during most of Permian time, and, after passing over the reefs, it entered the shallow inland sea where evaporation 


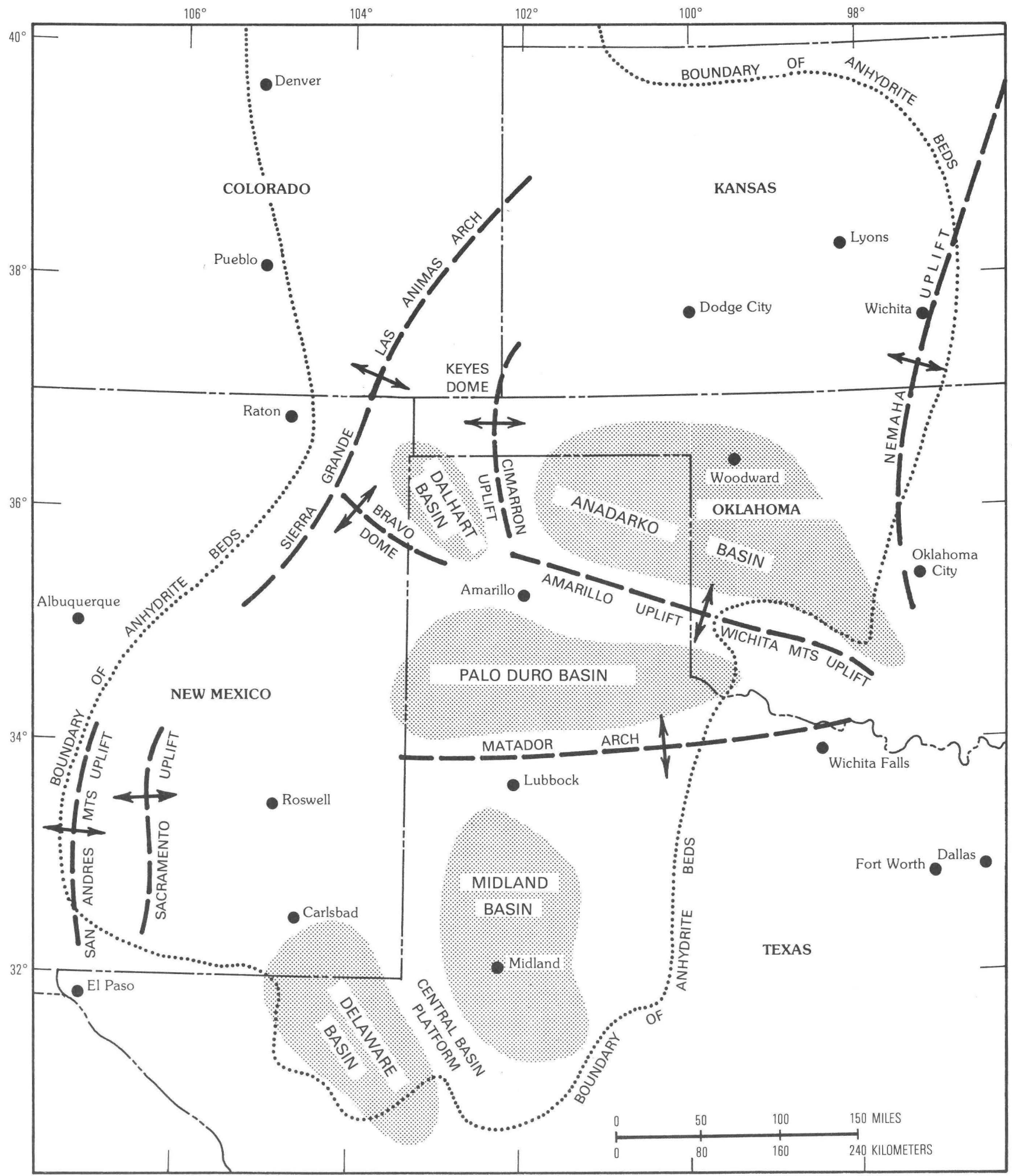

Figure 2.31. Map of the Permian basin of Southwestern United States showing principal tectonic provinces and boundary of the area underlain by beds of anhydrite. Five principal structural basins (stippled) contain thick Permian evaporites. 
of the water took place. Fresh water flowed seaward from land areas on the east and west and mixed with the marine and saline waters. Clastic sediments were deposited in alluvial and nearshore environments, whereas the evaporites were deposited in the more central parts of the inland sea or in the deeper parts of the various structural basins. Near the end of Permian time, a thick sequence of anhydrite and salt (Castile Formation) was deposited in a deep, restricted Delaware basin. The Castile Formation filled the Delaware basin, and so the youngest Permian evaporite units (Salado and Rustler Formations) extend beyond this basin a considerable distance into the Midland basin and northern shelf areas (fig. 2.32).

The history of the Permian basin has been one of tectonic stability since deposition of the evaporites. Minor amounts of subsidence have continued in the various structural basins, but the Permian and younger strata are virtually free of deformation and in most areas have dips of less than $0.5^{\circ}$. The region has not been affected by mountain-building processes, nor has it been covered by massive Pleistocene glaciers that spread over most of the northern United States.

General discussions of the geologic framework of various parts of the Permian basin, which place special emphasis on the occurrence and nature of evaporite deposits, are contained in the reports by Lang (1935, 1939), King (1934, 1942, 1948), Adams (1944, 1965), Galley (1958), Jordan and Vosburg (1963), McKee, Oriel, and others (1967a, 1967b), Hartman and Woodard (1971), Anderson and others (1972), Brokaw and others (1972), Johnson (1978a), Johnson and Gonzales (1978), and Dutton and others (1979).

The older evaporite deposits of the Permian basin are most widespread, whereas progressively younger evaporite units generally are more restricted to the southern part of the basin (fig. 2.33). Almost all anhydritic units in the basin consist of several to many beds of anhydrite, each typically $2-10 \mathrm{~m}$ thick, that are interbedded with other rocks such as limestone, dolomite, shale, sandstone, and halite (fig. 2.34). Exceptionally thick anhydrite beds are in: the Yeso Formation, which contains a gypsum bed $41 \mathrm{~m}$ thick in south-central New Mexico; the San Andres Limestone, which has several anhydrite beds more than $30 \mathrm{~m}$ thick in east-central New Mexico; the Artesia Group, which has several anhydrite beds reported to be nearly $30 \mathrm{~m}$ thick in southeastern New Mexico; the Cloud Chief Formation, which contains a single bed of anhydrite $30 \mathrm{~m}$ thick in the Anadarko basin; and the Castile Formation, which consists of several anhydrite beds that typically are each 30-125 m thick in the Delaware basin.
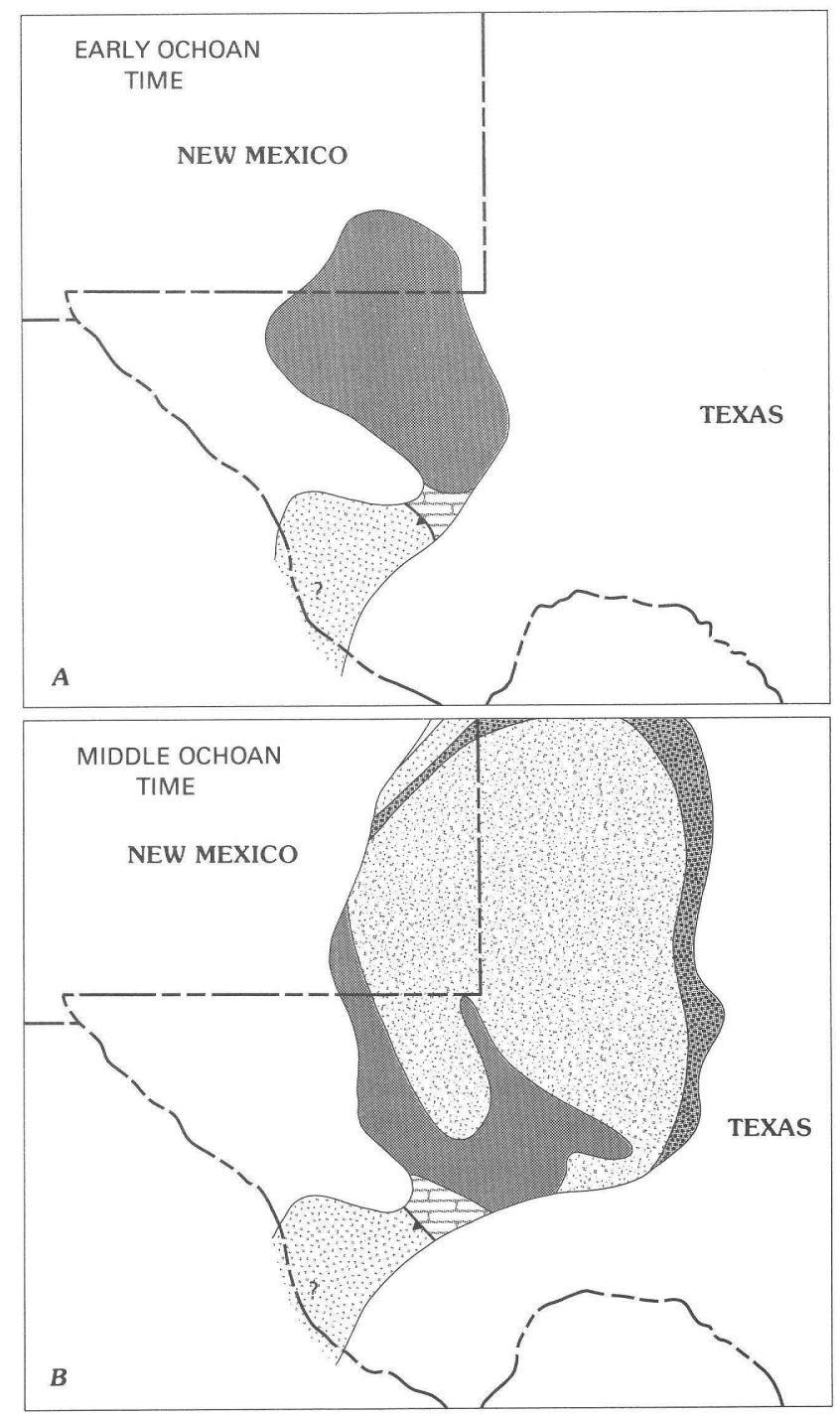

\section{EXPLANATION}

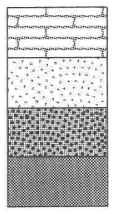

Limestone

Sandstone

Red beds

Anhydrite
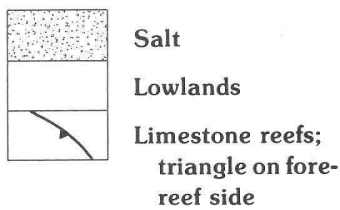

Figure 2.32. Paleogeographic maps of southwestern Texas and southeastern New Mexico during early $(A)$ and middle (B) Ochoan time (from King, 1948).

In addition to the principal Permian anhydrites to be discussed in this section, two other thin gypsum beds occur in the northeast corner of the Permian basin: the Lower Permian Easly Creek Shale contains $3 \mathrm{~m}$ of gypsum that has been mined at shallow depth at Blue 


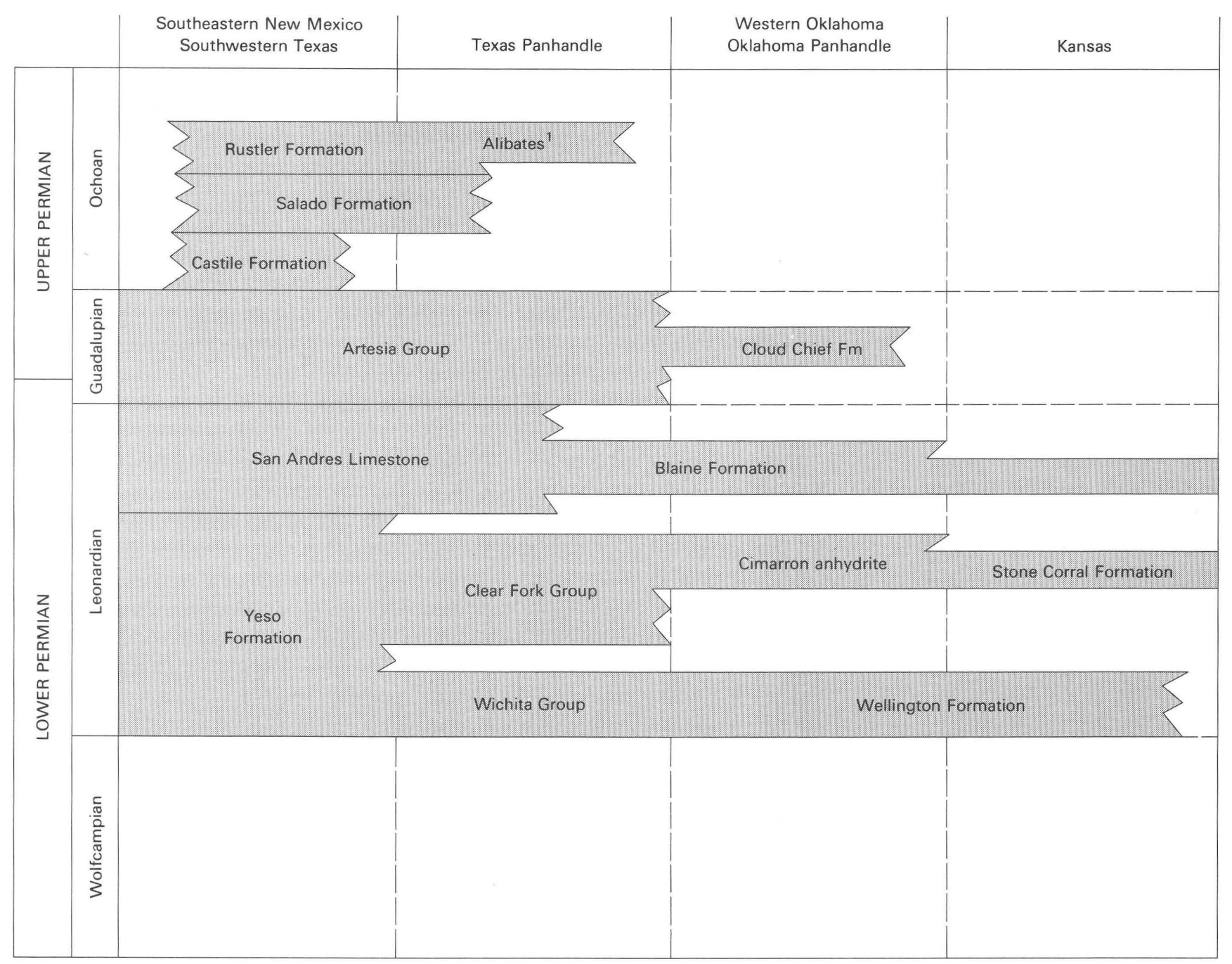

${ }^{1}$ Dolomite Lentil of Quartermaster Formation.

Figure 2.33. Diagram showing stratigraphic relationships of major anhydrite-bearing units in the Permian basin. Nonanhydrite units are omitted. Vertical dimensions are not related to thickness of anhydrite units.

Rapids in Marshall County, Kans. (Kulstad and others, 1956); and the Lower Permian Johnson Shale contains 3 $\mathrm{m}$ of gypsum about $50 \mathrm{~m}$ below the surface in Nemaha County, Nebr. (Burchett, 1970). Also, a single occurrence of gypsum of Late Pennsylvanian age is reported in the Permian basin area from the Panther Seep Formation (Virgilian and Missourian), which contains two outcropping gypsum beds 7 and $24 \mathrm{~m}$ thick in the San Andres Mountains of south-central New Mexico (Kottlowski and others, 1956). These beds of calcium sulfate may be thick beds of anhydrite in the subsurface.

\section{Wellington Formation and Wichita Group}

The oldest major evaporite unit in the Permian basin is Leonardian in age, and is referred to as the Wellington Formation in the Anadarko basin and in Kansas, the Panhandle lime (an informal name) in the Texas Panhandle, and as the Wichita Group in the Palo Duro basin (fig. 2.33). Anhydrite is the dominant lithology in most parts of the region, although it is interbedded with salt, shale, and dolomite. Individual anhydrite beds are typically $1-5 \mathrm{~m}$ thick, and the maximum 


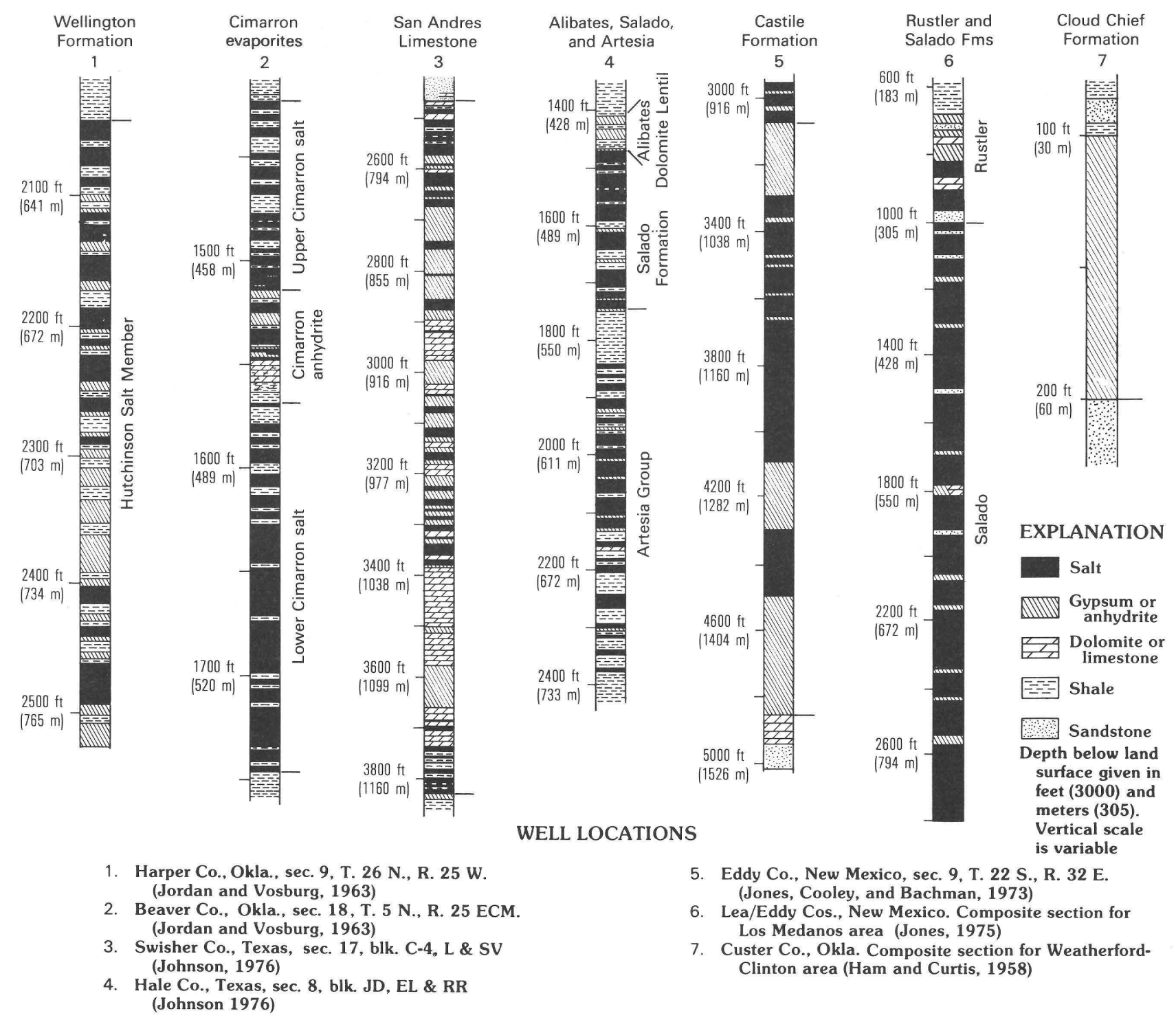

Figure 2.34. Representative well logs of major Permian units containing anhydrite in the Permian basin (modified from Johnson and Gonzales, 1978).

anhydrite-bed thickness is about $10 \mathrm{~m}$ (fig. 2.34). Principal studies of the anhydrite and other evaporites of the Wellington Formation and Wichita Group are those of Kulstad and others (1956), Jordan and Vosburg (1963), Jones (1965), Johnson (1976), Walters (1976, 1978), and Johnson and Gonzales (1978).

Anhydrite units of the Wellington Formation and Wichita Group underlie central and western Kansas, western Oklahoma, and the Texas Panhandle. They are interbedded with salt and shale on the north flank of the Anadarko basin in a unit referred to as the Hutchinson Salt Member of the Wellington in Kansas and northwestern Oklahoma, and with dolomite and shale elsewhere in the region.

Total thickness of the Wellington and Wichita ranges from 200 to $400 \mathrm{~m}$ in most parts of the region, and the greatest thickness is near the axis of the Anadarko basin (Jordan and Vosburg, 1963). The depth to the top of the evaporite unit is as shallow as $100 \mathrm{~m}$ in central Kansas, but increases to about $1,000 \mathrm{~m}$ southward into the Anadarko basin and westward into western Kansas. The evaporites are about $600 \mathrm{~m}$ deep over the Amarillo uplift in the Texas Panhandle; they plunge to about $1,000 \mathrm{~m}$ in depth in the Dalhart basin and to nearly $1,500 \mathrm{~m}$ in the Palo Duro basin.

Anhydrite beds range in thickness from 1 to $10 \mathrm{~m}$, and the thicker beds generally are in the lower and middle part of the sequence. Interbeds of salt, shale, and (or) dolomite also are commonly 1-10 m thick. Salt beds of the Hutchinson Salt Member were to have been the host rock for a federally proposed (but now abandoned) radioactive-waste-repository site known as Project Salt Vault, at Lyons in central Kansas (Bradshaw and McClain, 1971). 


\section{Lower Evaporites of Clear Fork Group}

The lower evaporites of the Clear Fork Group of Leonardian age contain beds of anhydrite 1-10 m thick in most parts of the Texas Panhandle (fig. 2.33). Interbedded anhydrite and other strata make up about $30-150 \mathrm{~m}$ of the basal part of the lower Clear Fork in the Palo Duro basin, but they thin northward to about $10 \mathrm{~m}$ on the south flank of the Anadarko basin. Beds of shale, dolomite, and salt 1-10 m thick are interbedded with the anhydrite. Limited data on this anhydrite sequence are available in reports by Jordan and Vosburg (1963), Johnson (1976), Johnson and Gonzales (1978), and Dutton and others (1979).

Depth to the top of the lower anhydrites of the Clear Fork is less than $500 \mathrm{~m}$ along the Amarillo uplift and the east side of the Palo Duro basin. From these areas, the depth increases to the south and the west toward the axis of the Palo Duro basin where the anhydrites are more than $1,500 \mathrm{~m}$ deep.

\section{Cimarron Anhydrite and Upper Evaporites of Clear Fork Group}

A widespread subsurface unit of Leonardian age, referred to informally as the Cimarron anhydrite and thought to be the stratigraphic equivalent of the Stone Corral Formation, extends across western Kansas and western Oklahoma and into the Texas Panhandle where it makes up the lower part of the upper evaporites of the Clear Fork Group (fig. 2.33). The unit consists of beds of anhydrite 2-10 m thick that are interbedded with beds of shale, salt, and dolomite of similar thickness. Total thickness of the Cimarron anhydrite sequence ranges from about 5 to $20 \mathrm{~m}$ north of the Amarillo uplift (fig. 2.34), and increases southward across the Palo Duro basin where the sequence of anhydritic interbeds is $50 \mathrm{~m}$ to almost $200 \mathrm{~m}$ thick in the deep part of the basin. Data on the Cimarron anhydrite are contained in reports by Merriam (1957), Jordan and Vosburg (1963), Johnson (1976), and Johnson and Gonzales (1978).

The depth of the anhydrite is as shallow as $100 \mathrm{~m}$ in central Kansas where the unit is part of the Stone Corral Formation (Merriam, 1957); it increases southwestward to about $600 \mathrm{~m}$ in the Anadarko basin and to about $1,500 \mathrm{~m}$ in the Palo Duro basin.

\section{Yeso Formation and Briggs Formation}

The Yeso Formation of Leonardian age consists of interbedded limestone, sandstone, and anhydrite in the shelf area of south-central and central New Mexico. The formation is stratigraphically equivalent to evaporites in the Wellington Formation, Wichita Group, lower and upper parts of the Clear Fork Group, and the Cimarron anhydrite farther northeast in the Permian basin (fig. 2.33). The most complete description of the Yeso was presented by Kottlowski and others (1956), who described outcrops of Yeso gypsum as much as $41 \mathrm{~m}$ thick in the San Andres Mountains of southern Socorro and northern Dona Ana Counties, N. Mex. Other brief descriptions include those of Weber and Kottlowski (1959), McKee, Oriel, and others (1967a), Kelley (1972b), and Foster and others (1972). The Briggs Formation, also of Leonardian age, contains about $190 \mathrm{~m}$ of anhydrite and gypsum interbedded with carbonates in the Malone Mountains of Hudspeth County, Tex. (Albritton and Smith, 1965).

Thickness of the Yeso Formation, which is less than $300 \mathrm{~m}$ in northeastern New Mexico, increases southward to $600-1,000 \mathrm{~m}$ in parts of Lincoln, Otero, and Chaves Counties, N. Mex. The depth to the top of the Yeso also increases from about $300 \mathrm{~m}$ on the north to as much as $1,500 \mathrm{~m}$ on the south.

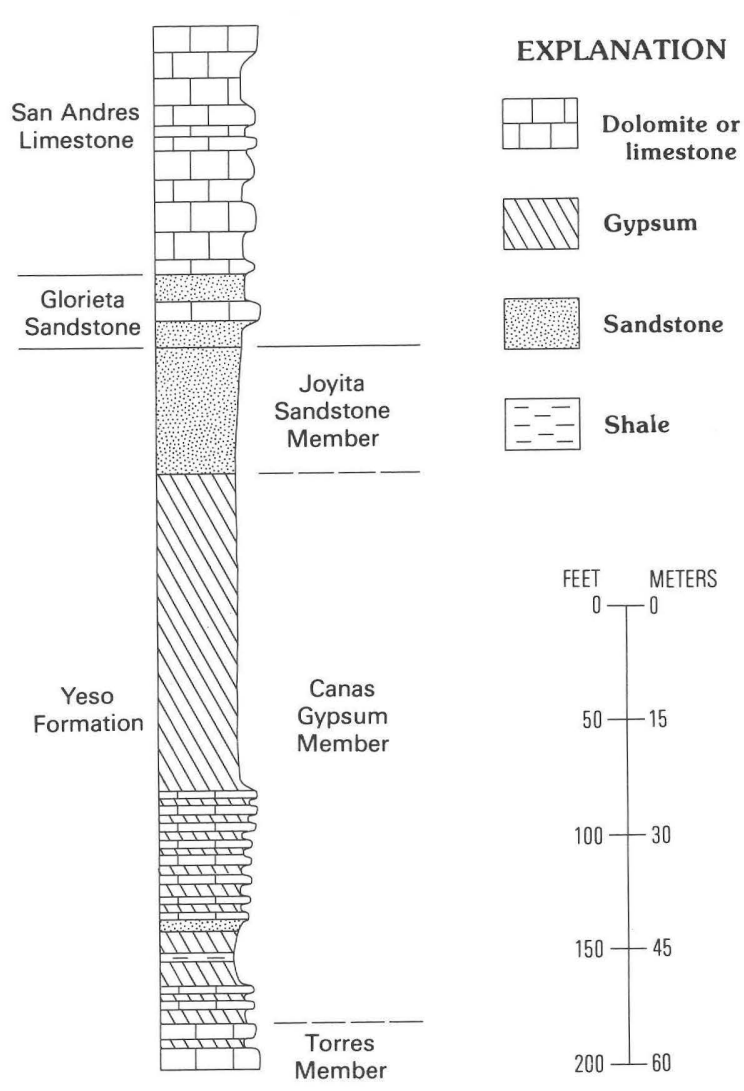

Figure 2.35. Columnar section of Permian upper Yeso Formation (containing thick Canas Gypsum Member at the top) and lower San Andres Limestone in the San Andres Mountains of southern New Mexico (modified from Kottlowski and others, 1956; Summers and Kottlowski, 1969). 
In outcrops of the San Andres Mountains (fig. $2.35)$, the Yeso is about $275-480 \mathrm{~m}$ thick and contains numerous gypsum beds $2-41 \mathrm{~m}$ thick (Kottlowski and others, 1956). The gypsum beds are light gray, fine crystalline, and medium bedded. Most gypsum units are 2-15 m thick, but the Canas Member at the top of the formation has a single bed of massive to banded gypsum $41 \mathrm{~m}$ thick. Data are not available on thickness and character of Yeso strata in the nearby subsurface, but the sulfate beds are undoubtedly anhydrite in part, and one or several of the anhydrite beds may be more than $30 \mathrm{~m}$ thick. Therefore, additional studies of the Yeso are needed near the San Andres Mountains, as well as north and east of the Sacramento Mountains.

The Briggs Formation crops out in the Malone Mountains to the south of the Diablo platform, and consists mainly of gypsum and anhydrite, but is interbedded with thin to thick beds and lenses of limestone and dolomite (Albritton and Smith, 1965). Gypsum on the outcrop occurs as thin lentils and lenses and as irregular bodies as much as $40 \mathrm{~m}$ thick. The gypsum is white to light gray and is remarkably free of detrital matter, except for tan or brown ferruginous streaks. The unit is being quarried at Gypsum Switch for use in plaster and cement manufacture.

Areas of exposure of the Briggs Formation are small, and the structure of the Malone Mountains is fairly complex. Fairly thick deposits of undisturbed anhydrite may exist in the formation at moderate depths near the mountains.

\section{San Andres Limestone and Blaine Formation}

The most widespread evaporite in the Permian basin is referred to as the San Andres Limestone in New Mexico and the southern part of the Texas Panhandle, and as the Blaine Formation north of the Amarillo uplift in Texas, Oklahoma, Kansas, and Colorado (fig. 2.33). The San Andres consists mainly of limestone and dolomite in the south, but these lithologies grade northward into a dolomite-anhydrite-halite facies and thence into an anhydrite-red beds-halite facies of the Blaine (fig. 2.36). Anhydrite beds in most areas are 1-10 m thick, but they may exceed $30 \mathrm{~m}$ in thickness in parts of central and east-central New Mexico. Reports describing San Andres gypsum or anhydrite are: Summers and Kottlowski (1969), Mourant and Shomaker (1970) Kelley (1971, 1972a), Foster and others (1972), Jones (1974), Johnson (1976), Johnson and Gonzales (1978), and Dutton and others (1979); studies

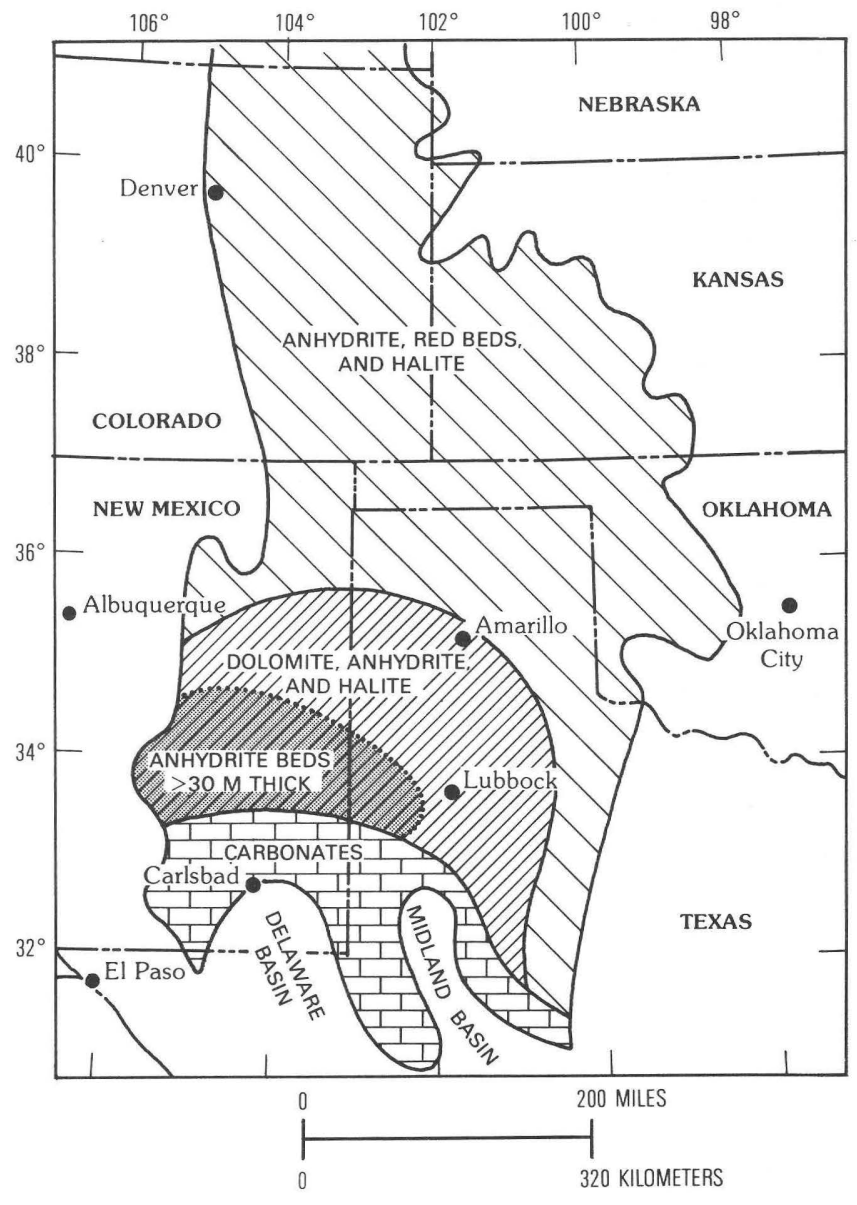

Figure 2.36. Map of Permian basin area showing principal facies of the San Andres and Blaine Formations and area (shaded) where individual anhydrite beds are reported to be as much as $30 \mathrm{~m}$ thick. The name San Andres Limestone generally is applied to the facies south and west of Amarillo; the name Blaine Formation generally is applied to the facies north and east of Amarillo.

of the Blaine Formation were reported by Jordan and Vosburg (1963), Fay (1964), Schumaker (1966), Johnson (1967, 1976, 1978b), Irwin (1977), Johnson and Gonzales (1978), and Holdoway (1978).

Anhydrite occurs at various stratigraphic positions in the San Andres and Blaine Formations in almost all parts of the Permian basin. Anhydrite is interbedded with limestone, dolomite, halite, and some clastics just north of the shelf that borders the Delaware and Midland basins, and a similar lithologic association extends northward across the Palo Duro basin to the vicinity of the Amarillo uplift, Bravo dome, and Sierra Grande uplift (fig. 2.31). Within this broad area of eastern New Mexico and northwestern Texas the San Andres is 
typically $300-500 \mathrm{~m}$ thick, and in most areas individual anhydrite beds are 1-10 m thick. The formation thins to the north and east due to depositional thinning and dissolution of interbedded salt at shallow depths near the outcrop and over the uplifts.

Individual beds of anhydrite may be as much as $30 \mathrm{~m}$ thick in all or part of Lincoln, Chaves, De Baca, Guadalupe, Roosevelt, and Lea Counties, N. Mex., and in parts of Bailey, Lamb, Cochran, Hockley, Lubbock, Yoakum, Terry, and Lynn Counties, Tex. (fig. 2.36). Within this district, the San Andres is $400-500 \mathrm{~m}$ thick, and the depth to the top of the formation ranges from less than $300 \mathrm{~m}$ in the west to $900-1,400 \mathrm{~m}$ in the center and the east.

Studies of San Andres evaporites in the eastcentral New Mexico district are not detailed, although those by Summers and Kottlowski (1969), Mourant and Shomaker (1970), and Kelley (1971) indicated abnormally thick anhydrite (or gypsum) beds. Mourant and Shomaker (1970) described anhydrite or gypsum beds nearly $20-60 \mathrm{~m}$ thick at depths of $120-440 \mathrm{~m}$ in De Baca County; the thickest unit, $60 \mathrm{~m}$ at a depth of $440 \mathrm{~m}$, is based on the sample log of a well drilled in sec. 26, T. 1 S., R. 26 E. Kelley (1971) described evaporites in the upper part of the San Andres in outcrops, and mentioned the presence of about $250 \mathrm{~m}$ of gypsum and a few thin beds of dolomite in sec. 15, T. 5 S., R. 11 E., Lincoln County. Summers and Kottlowski (1969) showed the log of a well in sec. 24, T. 7 S., R. 29 E., Chaves County, that contains anhydrite beds $10-15 \mathrm{~m}$ thick at a depth of about $900 \mathrm{~m}$. The density $\log$ of the Cities Service No. 1 State "BP" well drilled in sec. 2, T. 10 S., R. 36 E., Lea County, indicates the presence of $58 \mathrm{~m}$ of anhydrite, and several thin non-anhydrite beds about $1,645 \mathrm{~m}$ below the surface.

Other data are not available that would enable further characterization of anhydrites in this east-central New Mexico district. However, the limited data do indicate the potential for thick beds at moderate depths, and thus more study is needed in this area.

In the northern part of the Permian basin, strata of the same age as the San Andres contain interbedded anhydrite, red beds, and salt called the Flowerpot, Blaine, and Dog Creek Formations, but only the Blaine has significant anhydrite beds. The Blaine Formation typically ranges from $15-100 \mathrm{~m}$ in thickness and commonly contains two to nine separate beds of anhydrite that are $3-10 \mathrm{~m}$ thick. The Blaine is exposed along the east side of the Permian basin, where outcrops of highpurity gypsum are mined extensively, and the formation dips to depths of $300 \mathrm{~m}$ to more than $1,000 \mathrm{~m}$ in other parts of the basin.

\section{Artesia Group}

The Artesia Group of late Guadalupian age overlies the San Andres Limestone in eastern New Mexico and much of nearby Texas (fig. 2.33), where it consists mainly of anhydrite and halite interbedded with sandstone, shale, and dolomite. Most anhydrite beds are 1-10 m thick, but some may be as much as $30 \mathrm{~m}$ thick. Studies of the Artesia Group that contain significant information on the evaporite strata are those of Tait and others (1962), Hayes (1964), Havenor (1968), Kelley (1972a, 1972b), Jones (1974), Sarg (1977), Johnson and Gonzales (1978), and Dutton and others (1979).

The Artesia Group as defined by Tait and others (1972) consists of five formations, which are (in ascending order) the Grayburg, Queen, Seven Rivers, Yates, and Tansill. Anhydrite occurs in all five formations in many parts of the region.

Thickness of the Artesia Group is about 250$300 \mathrm{~m}$ to the northeast in the Palo Duro basin, and $300-600 \mathrm{~m}$ to the south in the Midland basin and the shelf areas surrounding the Midland and Delaware basins. The depth to the top of the Artesia Group is $300-600 \mathrm{~m}$ in most parts of the Palo Duro basin and $600-1,200 \mathrm{~m}$ in most parts of the Midland basin. In far eastern New Mexico, the top of the Artesia is about $600 \mathrm{~m}$ below the surface, but the depth decreases westward to the Pecos River where the Artesia crops out.

Anhydrite, salt, and red-bed clastics are interbedded in all five formations of the Artesia Group over most of the region (fig. 2.34). Individual rock units are typically $1-10 \mathrm{~m}$ thick, although some beds locally are 20-30 m thick.

Tait and others (1962) presented several subsurface cross sections of the Artesia Group, which indicate that several of the anhydrite beds are nearly $30 \mathrm{~m}$ thick in some parts of the shelf area north of the Delaware basin. This thickness is shown especially on their cross section through parts of Lea and Eddy Counties, N. Mex., where the top of the Artesia Group is generally 300-900 m below the surface. Studies of the Artesia Group have not been done in this area with sufficient detail to establish firmly the thickness of individual anhydrite beds, but some beds as much as $30 \mathrm{~m}$ thick probably are present at moderate depths.

\section{Cloud Chief Formation}

The Cloud Chief Formation is $60-100 \mathrm{~m}$ thick; it consists mainly of red-brown shale interbedded with sandstone and it contains several beds of gypsum or anhydrite that are typically 1-2 m thick. A single bed of gypsum $30 \mathrm{~m}$ thick at the base of the formation crops out 
in the eastern part of the Anadarko basin, but this bed is largely anhydrite in the shallow subsurface nearby. This bed of gypsum or anhydrite was referred to originally as the Cloud Chief Gypsum, but more recently it has been called the Moccasin Creek Gypsum Member at the base of the Cloud Chief Formation (Fay, 1965, 1979). The lower part of the Cloud Chief, including the thick bed of gypsum or anhydrite, is believed to be Guadalupian in age, whereas the upper part of the formation is Ochoan (Johnson, 1978a). Other principal references to the Moccasin Creek Gypsum Member are Ham and Curtis (1958) and Johnson (1978b).

Thick gypsum in the Moccasin Creek Member crops out in eastern Washita and Custer Counties, Okla. The unit is white to pinkish-white alabaster in much of the area, consists of 90-98 percent gypsum, and is quarried at several sites. The full thickness of the Moccasin Creek Member in this area is about $30 \mathrm{~m}$, but cores drilled into gypsum outcrops have found only 5-15 $\mathrm{m}$ of anhydrite in the lower part of the bed at depths as shallow as $10 \mathrm{~m}$ (Ham and Curtis, 1958).

The Moccasin Creek Gypsum Member dips gently to the west, and much of the unit also grades laterally into red-brown shale in that direction. This bed is mostly anhydrite in the Anadarko basin where it is only about 3-10 m thick and from $100 \mathrm{~m}$ to a maximum of $200 \mathrm{~m}$ below the surface. Thus, the bed is as much as $30 \mathrm{~m}$ thick only on the outcrop and at a depth less than $100 \mathrm{~m}$; at greater depths the equivalent anhydrite bed is much thinner.

\section{Castile Formation}

The evaporites of the Castile, Salado, and Rustler Formations of Ochoan age in the Delaware basin constitute the most extensive and thickest evaporite sequence in North America. These deposits are the culmination of evaporite deposition that began during Leonardian time in Kansas, then migrated toward the southwest as extensive Permian seas began to withdraw from the area of the Southwestern United States (fig. 2.33). The series is more than $1,500 \mathrm{~m}$ thick within the Delaware basin and more than $450 \mathrm{~m}$ thick where these deposits extend north and east beyond the confines of the basin (fig. 2.32).

The Castile Formation, which consists predominantly of anhydrite, is confined to the Delaware basin. The contact between the Castile and the underlying Bell Canyon Formation of the Delaware Mountain Group (Guadalupian) is gradational, and laminated siltstone and claystone change upward to laminated anhydrite within about $1 \mathrm{~m}$ (Anderson and others, 1972; Cys, 1978). Interbeds of halite in the
Castile Formation and in the overlying Salado Formation are confined to the eastern half of the basin (fig. 2.37). The western limits of individual salt beds have been shown to be the result of dissolution of salt rather than the original limits of salt deposition (Anderson and others, 1972, 1978). Consequently, most beds of halite in the eastern part of the basin are correlative with beds of brecciated anhydrite in the western part of the basin that resulted from collapse and lowering of overlying stratigraphic units (fig. 2.38). Anderson (1982) calculated that an average of about 50 percent of the salt deposited in the Castile and lower Salado Formations has been dissolved, although more than 70 percent of the salt in certain individual beds has been dissolved.

Anderson and others (1972) subdivided the Castile Formation into four anhydrite members and three halite members (fig. 2.38). The thickness of the lowermost anhydrite unit (anhydrite I) is fairly constant between 50 and $60 \mathrm{~m}$ in the western part of the basin and increases to more than $100 \mathrm{~m}$ in the eastern part of the basin (fig. 2.39). The thickness of the anhydrite II member, like the thickness of anhydrite I, increases from west to east (fig. 2.40)-from a fairly uniform $23-30 \mathrm{~m}$ thick in the west to more than $60 \mathrm{~m}$ in the east. The anhydrite III member is $85-90 \mathrm{~m}$ thick over most of the basin. It also thickens from west to east, but at a much lesser rate than does either anhydrite I or anhydrite II. The lowest halite bed of the overlying halite III member is absent over the western part of the basin, and an anhydrite bed within halite III lies directly on anhydrite of anhydrite III. The lack of good halite marker beds and the relatively uniform thickness of anhydrite III make construction of a meaningful isopach map of this anhydrite unit difficult, but the unit is generally $85-105 \mathrm{~m}$ thick. The thickness of the anhydrite IV member is even more difficult to map because the uppermost halite bed of underlying halite III and the lowermost halite bed of the overlying Salado Formation are not present over much of the basin.

Although the thicknesses of individual beds of anhydrite within the Castile Formation increase from west to east across the Delaware basin, the thickest composite sections of anhydrite occur in the western part of the basin (west of the 0 -salt line in fig. 2.37) as a result of dissolution of halite interbeds. Most of the Castile Formation consists of remarkably distinct interlaminations of organically stained calcite and anhydrite (fig. 2.41) that are assumed to represent annual increments of sedimentation (varves). Calcite-anhydrite couplets average about $2 \mathrm{~mm}$ in thickness (Anderson and others, 1972). The petrologic and geochemical characteristics of the calcite-anhydrite laminations of the Castile have been 


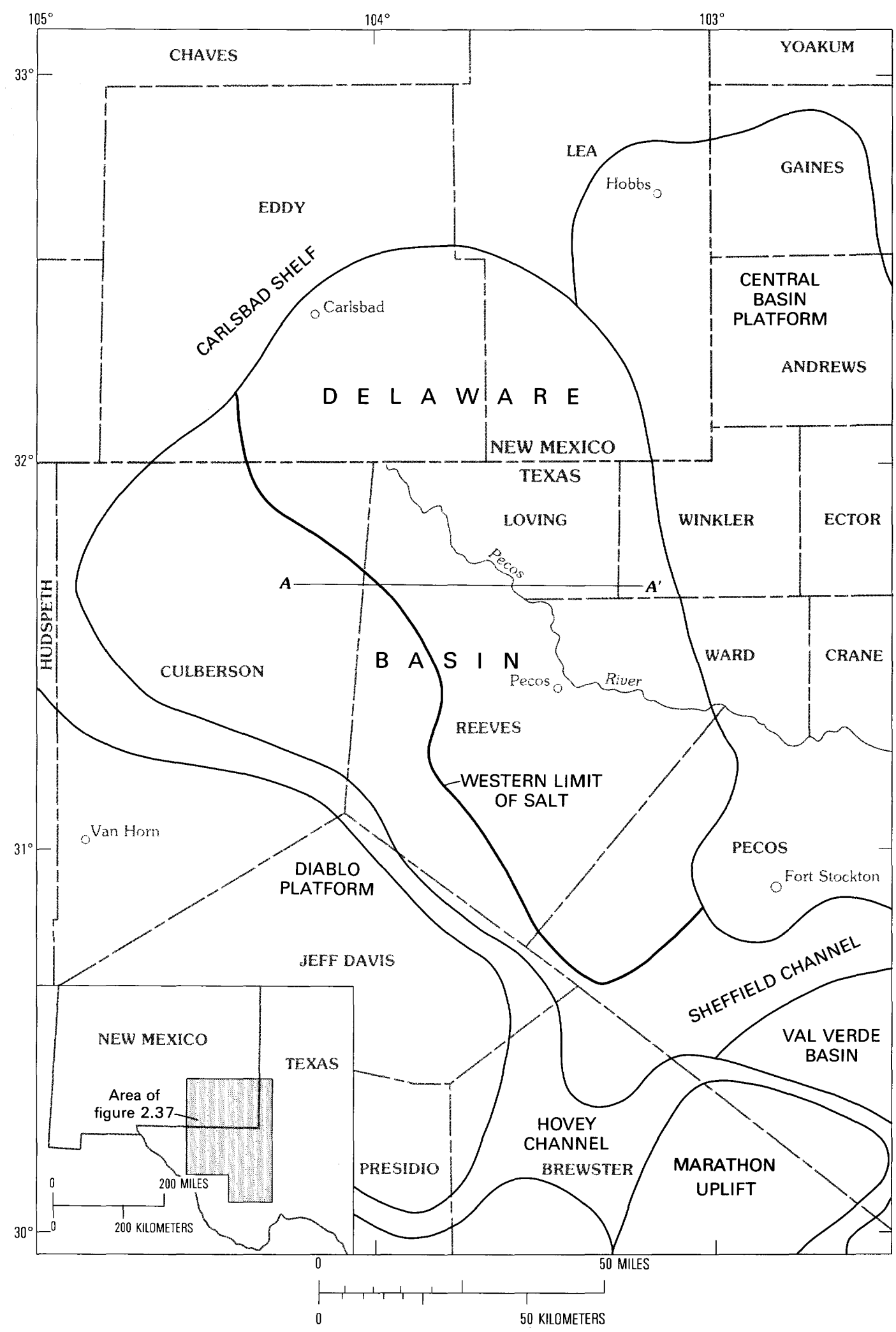

Figure 2.37. Map of the Delaware basin and surrounding region of southwestern Texas and southeastern New Mexico. The line $A-A^{\prime}$ corresponds to the cross section in figure 2.38. 


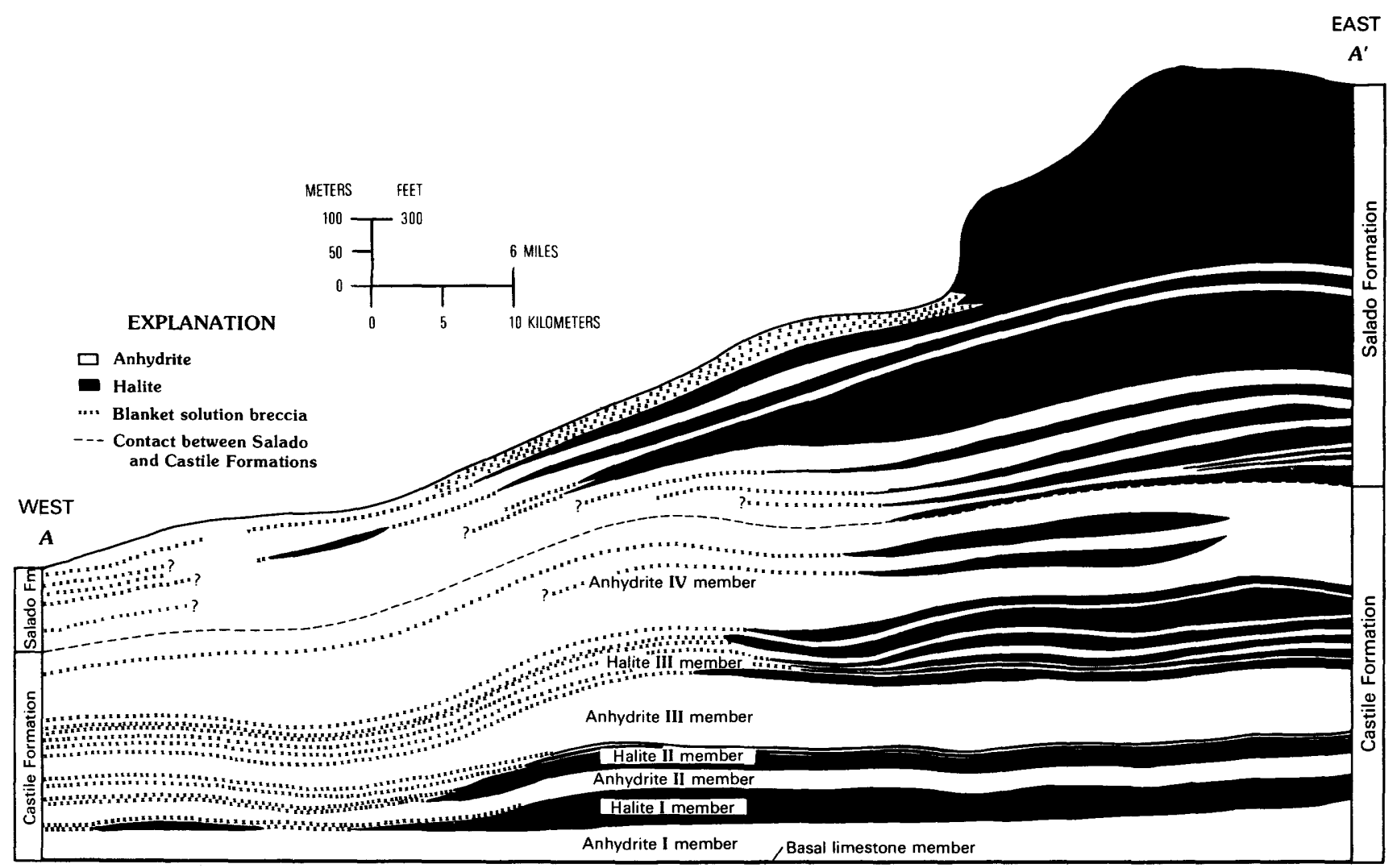

Figure 2.38. Diagrammatic east-west cross section of Castile and Salado Formations from Culberson County, Tex. $(A)$, to Winkler County, Tex. ( $A^{\prime}$ ) (from Anderson and others, 1972). Location of cross section shown on figure 2.37.

described by Udden (1924), Adams (1944), Anderson and Kirkland (1966), Kirkland and Anderson (1970), Anderson and others (1972), and Dean and Anderson (1974, 1978).

Within individual anhydrite beds of the Castile Formation and the lower part of the overlying Salado Formation, cyclic variations in structures and textures of the anhydrite have been interpreted by Dean and Anderson (1978) as representing cyclic changes in salinity within the basin. An average petrologic cycle is about $4 \mathrm{~m}$ thick and represents a time span of about 2,700 years. A complete cycle begins with thin laminae couplets of anhydrite and calcite in which calcite may be the dominant component (fig. 2.41). The anhydrite within individual couplets increases in thickness upward within the cycle, and forms the calcite-banded anhydrite typical of most of the Castile Formation and the lower part of the Salado Formation (bedded massive anhydrite of Maiklem and others, 1969) (fig. 2.41). Near the end of a cycle, nodular anhydrite has formed by recrystallization within thicker anhydrite laminae. When fully formed, the nodular anhydrite has the appearance of bedded, nodular, mosaic anhydrite of Maiklem and others (1969). A complete cycle ends with a bed of halite, mostly containing laminae of anhydrite, immediately overlying nodular anhydrite. In the western part of the basin, however, the dissolving of halite beds has left dissolution breccias that consist of elongate fragments of laminated anhydrite suspended in a matrix of anhydrite (fig. 2.42; Anderson and others, 1972, 1978). Anderson and others (1978) have shown that $0.3 \mathrm{~m}$ of dissolution breccia in the western part of the basin is equivalent to between 6 and $9 \mathrm{~m}$ of halite in the eastern part of the basin. Therefore, the thick composite anhydrite sections in the western part of the basin consist of cyclic alternations of laminated and nodular anhydrite with some nodular zones overlain by dissolution-brecciated anhydrite. Laminated anhydrite occupies most of the 4-m-thickness of an average cycle.

Most of the inferred salinity cycles are incomplete, because not every bed of nodular anhydrite is overlain by halite (or dissolution breccia). However, nodular anhydrite is best developed in complete cycles, and so the original laminated anhydrite that is immediately below a bed of halite (or dissolution breccia) is almost completely recrystallized into nodular anhydrite. 


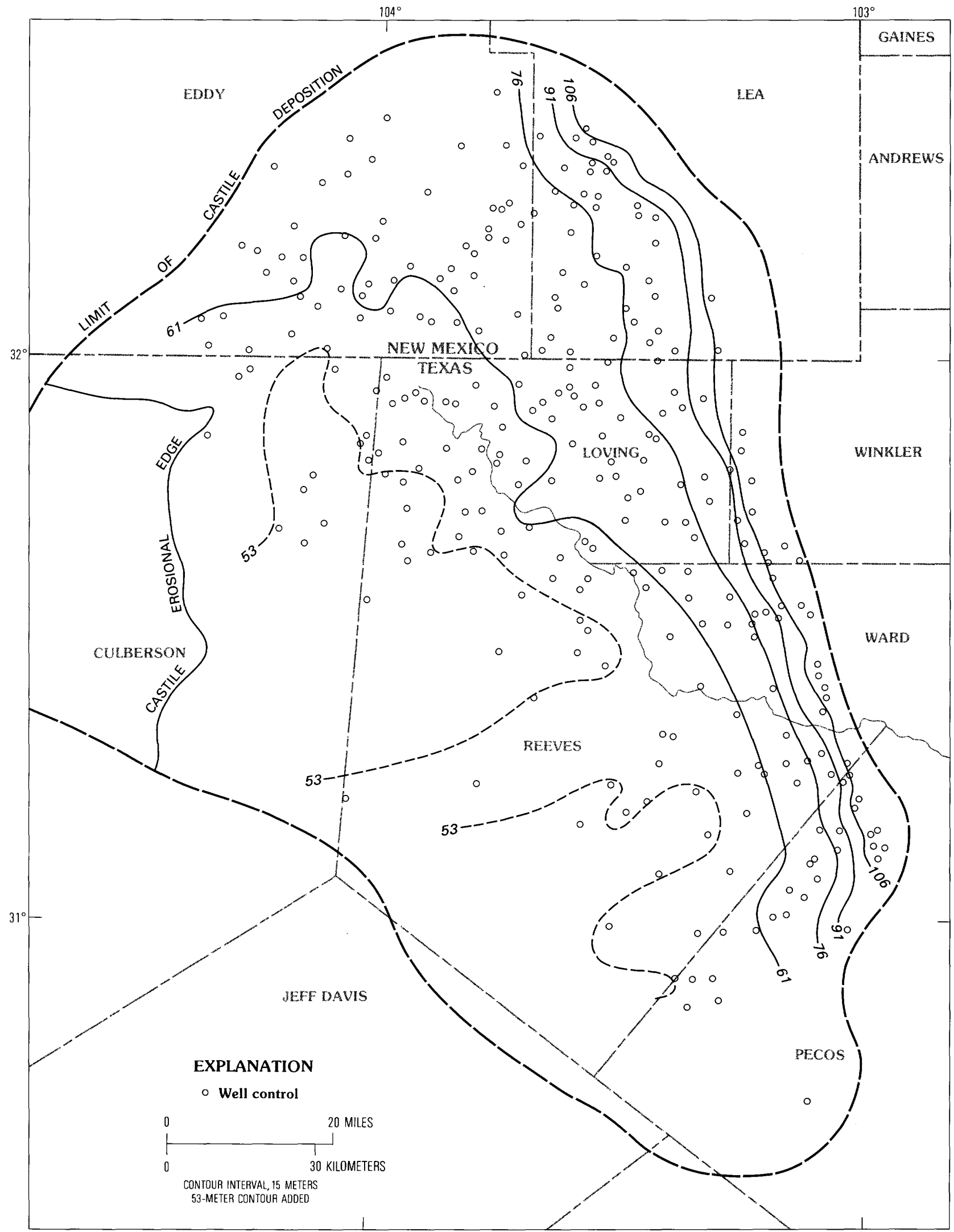

Figure 2.39. Thickness distribution of anhydrite I member, Castile Formation. Contour lines are dashed where inferred (modified from Anderson and others, 1972). 


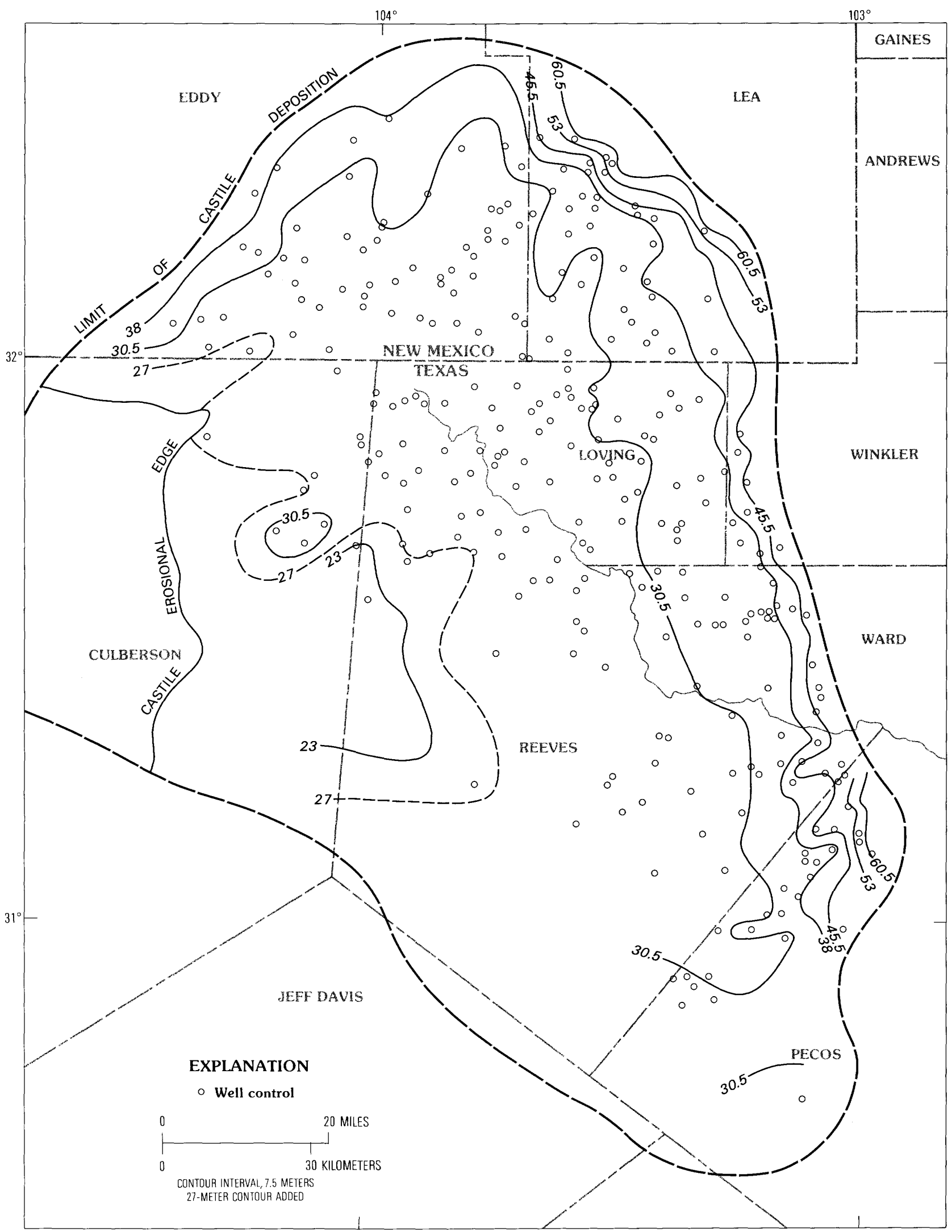

Figure 2.40. Thickness distribution of anhydrite II member, Castile Formation (modified from Anderson and others, 1972). 


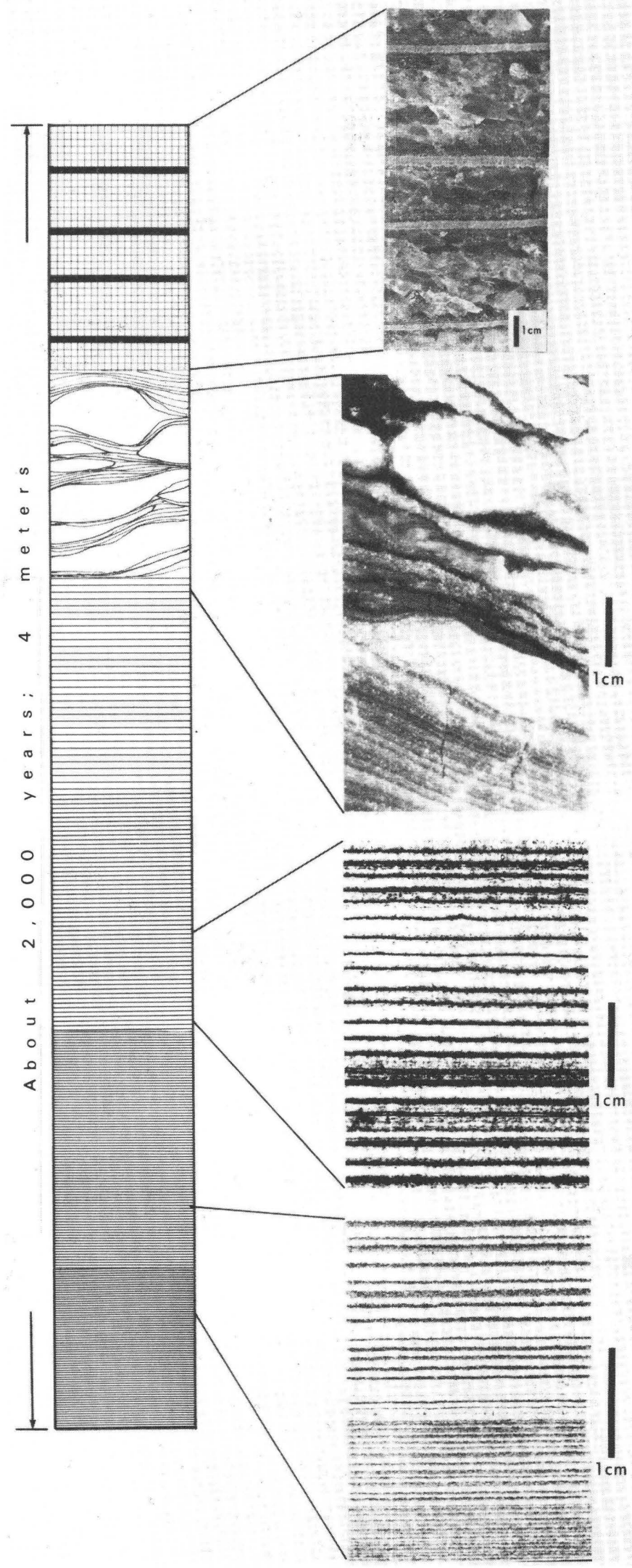

Figure 2.41. Diagrammatic illustration (left) of a complete salinity cycle in the Castile Formation and lower part of the Salado Formation (modified from Dean and Anderson, 1978). Right column consists of core photographs illustrating four different parts of a salinity cycle.

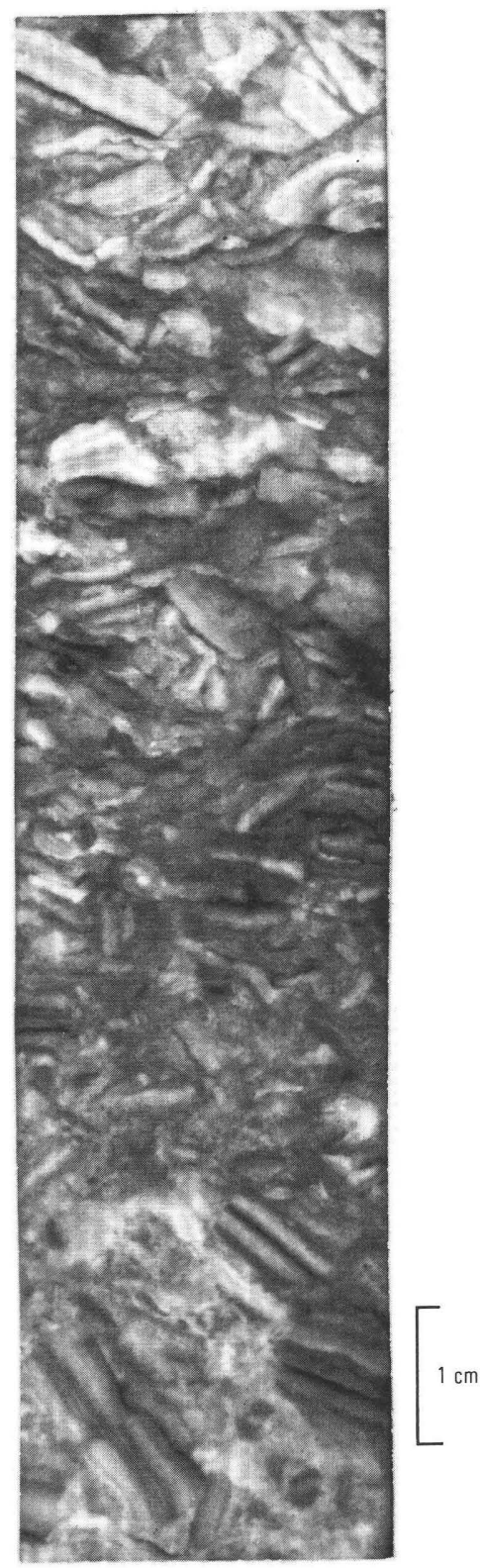

Figure 2.42. Core photographs of blanket dissolution breccia correlative with halite I in the Castile Formation.

At the base of a cycle, anhydrite may be less abundant than is calcite, although this is rare. In the typical calcite-banded anhydrite in the middle of a cycle-the material that makes up most of the Castilethe rock consists of 85-90 percent anhydrite and 10-15 percent calcite (Dean and Anderson, 1978). The anhydrite beds of the entire Castile Formation average about 85 percent anhydrite and 15 percent calcite (Dean and Anderson, 1974).

Depth to the top of the the calcite-banded anhydrite of the Castile Formation ranges from less than $150 \mathrm{~m}$ 
in the western part of the basin to more than $1,200 \mathrm{~m}$ in the eastern part (fig. 2.43).

\section{Salado Formation}

The Salado Formation of Ochoan age is one of the principal evaporite units in the Permian basin, and one of the largest deposits of halite in North America (Brokaw and others, 1972). The Salado consists mainly of halite in the area of the Delaware and Midland basins and on the shelf areas north of the basins, but it also contains anhydrite beds $1-10 \mathrm{~m}$ thick. In addition, the potassiumbearing minerals that are interbedded with halite in the central part of the formation are the principal sources of potash in the United States. The contact between the Castile and Salado Formations was considered by Adams (1944) to be an angular unconformity. Jones and his coworkers (Brokaw and others, 1972; Jones and others, 1973) considered the contact to be conformable, but recent evidence presented by Anderson and others (1978) and Anderson (1982) suggests that the unconformity between the two formations suggested by Adams (1944) does exist. Whereas the Castile Formation is characterized by relatively pure lithologies (anhydrite or halite) and a dominance of anhydrite, the Salado Formation is characterized by less pure lithologies, by many thin interbeds of differing lithologies, and dominance of halite (85-90 percent of the formation; Brokaw and others, 1972) (fig. 2.34).

Much recent study has focused on the possible use of the Salado salts as a host rock for radioactive waste at the Waste Isolation Pilot Plant (WIPP) site in southeast New Mexico, about $30 \mathrm{~km}$ east of Carlsbad. Among the recent reports on the Salado Formation are those of Adams (1969), Brokaw and others (1972), Jones and others (1973), Jones (1975), Cheeseman and Lorenz (1977), Powers and others (1978), and Anderson (1982).

The thickness of the Salado Formation ranges from between 150 and $300 \mathrm{~m}$ over most of the western half of the Delaware basin to more than $700 \mathrm{~m}$ along the eastern margin of the basin (Anderson and others, 1972). Depth to the top of the Salado Formation is typically $300-750 \mathrm{~m}$ in most parts of the Delaware and Midland basins and on the shelf areas farther north. Within the Palo Duro basin, the depth ranges from $300-600 \mathrm{~m}$.

Anhydrite beds are common in the Salado Formation, particularly in the lower part, but none exceeds a thickness of about $10 \mathrm{~m}$. Most of the anhydrite occurs as thin (mostly less than $1 \mathrm{~m}$ ) interbeds within halite. Although the anhydrite beds are thin, they are laterally persistent and provide excellent marker beds for stratigraphic control (Lang, 1935, 1939; Adams, 1944; Jones, 1960; Jones and others, 1973). The thickest of the anhydrite marker beds in the Salado-the Cowden Anhy- drite Member-occurs about $90 \mathrm{~m}$ above the CastileSalado contact and is about $6 \mathrm{~m}$ thick. Snider (1966) calculated that the cumulative thickness of anhydrite beds in the Salado Formation along the eastern margin of the Delaware basin increases from north to south - from about $60 \mathrm{~m}$ in Lea County, N. Mex., to more than $200 \mathrm{~m}$ in Reeves County, Tex.; this percentage increase is from about 11 to 30 percent of the entire formation.

The calcite-banded anhydrite typical of the Castile Formation persists into the lower anhydrite units of the Salado Formation in the central part of the Delaware basin (Anderson, 1982). In the northern part of the basin, however, the anhydrite units of the Salado and even the upper part of the Castile have lost this typical banded character. Some anhydrite marker beds in the Salado Formation are interlaminated with thin, dark films, apparently of organic matter, but the couplets are on a scale of $1-2 \mathrm{~cm}$, rather than the 1-2 $\mathrm{mm}$ in the typical "banded anhydrite" of the Castile (Anderson, 1982). The anhydrite marker beds of the Salado almost everywhere contain inclusions of salt and stringers of magnesite or dolomite (Adams, 1944).

\section{Rustler Formation and Alibates Dolomite Lentil}

The Rustler Formation, youngest of the anhydritebearing units in the Permian basin, is limited to the Delaware and Midland basins and nearby shelf areas. The formation is Ochoan in age, and its upper part is believed to be equivalent to the anhydrite-bearing Alibates Dolomite Lentil of the Quartermaster Formation farther north in the Texas Panhandle (Fay, 1965; Johnson, 1978a). In subsurface the formation is mostly anhydrite and salt, but it also contains interbeds of dolomite, polyhalite, sandstone, and shale (Lang 1935, 1939; Adams, 1944; Brokaw and others, 1972; Jones and others, 1973; Powers and others, 1978; fig. 2.34). Anhydrite beds in the Rustler and Alibates range from 1-15 m in thickness. Jones (1960) described the Rustler in the subsurface in the northern part of the Delaware basin as containing 43 percent halite and other chloride minerals; 30 percent anhydrite, polyhalite, gypsum, and other sulfate minerals; 17 percent clastic rocks; and 10 percent limestone, dolomite, and magnesite. Adams (1944) considered the Rustler to be composed of two main parts: an upper zone about $30-50$ m thick that consists mainly of anhydrite interbedded with fine-grained clastics and dolomite; and a lower zone that consists of interbedded anhydrite, dolomite, sandstone and shale.

The Rustler is best known from outcrops, but construction of a complete stratigraphic section is 


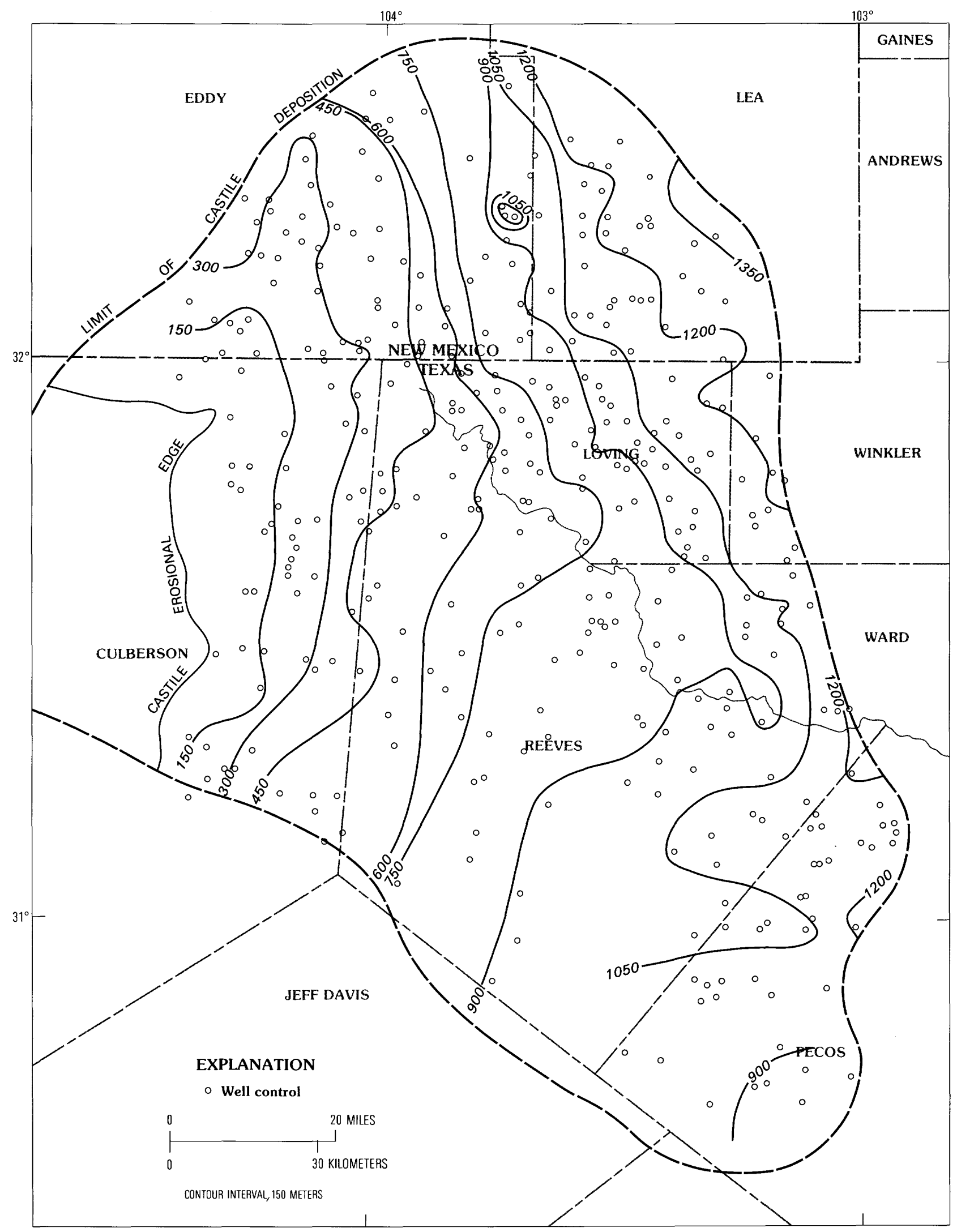

Figure 2.43. Depth to top of laminated anhydrite in the Castile Formation (modified from Dean, 1967). 
difficult because the original lithologies have been highly altered by deformation, hydration, and dissolution. Most of the rocks exposed in outcrop are porous to even cavernous, friable, strongly jointed, and brecciated. The most persistent stratigraphic markers are two beds of dolomite-one in the lower part of the formation called the Culebra Dolomite Member and one in the upper part of the formation called the Magenta Dolomite Member (Adams, 1944).

The thickness of the Rustler Formation ranges from about 75 to $180 \mathrm{~m}$ over most of the northern and eastern parts of the Delaware basin, and it generally increases toward the southern part of the basin. The Rustler is unconformably overlain by the reddish-brown clastic rocks of the Upper Permian Dewey Lake Red Beds. The depth to the top of the Rustler ranges from 150 to $600 \mathrm{~m}$ in most parts of the Delaware and Midland basins and nearby shelf areas.

The Alibates Dolomite Lentil of the Quartermaster Formation in most parts of the Texas Panhandle consists of two beds of anhydrite or dolomite, each 2-10 $\mathrm{m}$ thick, separated by $2-6 \mathrm{~m}$ of red-brown shale. The Alibates crops out in bluffs overlooking several of the deeply incised streams and rivers of the region, and it is generally $100-200 \mathrm{~m}$ beneath the surface in divides between the major rivers.

\section{NORTHERN DENVER BASIN- PENNSYLVANIAN THROUGH TRIASSIC}

A fairly thick sequence of evaporites is present in the northern Denver basin in parts of western Nebraska, northeastern Colorado, and southeastern Wyoming (fig. 2.1). Parts of the area also have been referred to as the Lusk embayment (Bates, 1955) and as the Alliance basin (MacLachlan and Bieber, 1963; Maughan, 1966; Rascoe and Baars, 1972). These reports, and those by Maher (1960), Momper (1963), Hoyt (1963), Larson and others (1963), Lane (1973), and Irwin (1977), are the principal sources of information on evaporite deposits in this area. Total thickness of the anhydrite-bearing strata ranges from 150 to $300 \mathrm{~m}$, and the anhydrite is interbedded with carbonates, clastics, and several salt units. The evaporites occur in Wyoming and Nebraska in the Minnelusa Formation and its equivalents (Pennsylvanian and Lower Permian) and in the Lykins (or Goose Egg) Formation and its equivalents (Permian and Lower Triassic). Individual anhydrite beds are commonly 2-10 m thick, and some beds in the Lower Permian are reported to be as much as $23-30 \mathrm{~m}$ thick. Depth to the top of the anhydritic units ranges from 600 to $2,400 \mathrm{~m}$.
Pennsylvanian and Permian strata in most parts of the northern Denver basin are composed of carbonates, red beds, and evaporites that were deposited in shallow marine or shelf environments. The region subsequently received a thick accumulation of Cretaceous sediments; the depocenter was to the west and southwest, adjacent to the Rocky Mountain front of Colorado and southeastern Wyoming. The basin is asymmetrical, and strata dip gently to the southwest across western Nebraska less than $1^{\circ}$. The strata generally are undeformed in the principal evaporite province of the basin (Nebraska Panhandle and adjacent areas).

Strata in the Pennsylvanian and Lower Permian (Wolfcampian and Leonardian) in Wyoming and Nebraska are referred to as the Minnelusa Formation by many workers. Anhydrite beds occur with carbonates and clastics in the Desmoinesian, Missourian, and Virgilian in the far northern part of the basin (Hoyt, 1963). These beds are typically only $2-10 \mathrm{~m}$ thick and are at depths of from 900 to perhaps $1,500 \mathrm{~m}$.

Principal anhydrite beds are in the Wolfcampian and Leonardian Series. Wolfcampian strata are 120-160 m thick in a large part of western Nebraska, and anhydrite makes up more than 50 percent of the strata in much of this area (MacLachlan and Bieber, 1963). Anhydrite beds are typically $2-15 \mathrm{~m}$ thick in the area and range from about $900 \mathrm{~m}$ deep in the northeast to about 2,400 $\mathrm{m}$ deep in the southwest. The thickest Wolfcampian anhydrites reported are two beds 17 and $23 \mathrm{~m}$ thick at depths of $1,160 \mathrm{~m}$ in Sheridan County, Nebr. (fig. 2.44).

Leonardian strata are mainly shales and siltstones, but anhydrite in the Stone Corral Formation at the top of the sequence is commonly 5-10 m thick and at a depth of $600-1,500 \mathrm{~m}$. The maximum thickness reported is $30 \mathrm{~m}$ of anhydrite at a depth of $1,295 \mathrm{~m}$ in Phillips County, northeastern Colorado (fig. 2.45).

Permian and Lower Triassic strata of the northern Denver basin, commonly 90-180 m thick, are variously placed in the Lykins Formation (Rascoe and Baars, 1972) or in the Goose Egg Formation (Lane, 1973). These strata are further subdivided into a number of other units, and those that contain anhydrite beds include the Satanka Shale and Blaine Formation, and the Opeche, Minnekahta (or Sybille Member of some authors), Forelle, Ervay (all Permian), and Little Medicine (Triassic) Members of the Goose Egg Formation. The thickness of individual anhydrite beds throughout the Lykins Formation is typically $2-10 \mathrm{~m}$, and the maximum thickness is probably about $12 \mathrm{~m}$. Depths to these beds range from about $600-900 \mathrm{~m}$ in the northeast to as much as $2,400 \mathrm{~m}$ in the southwest. 
1

Sec. 2,

T. 30 N., R. 51 W.

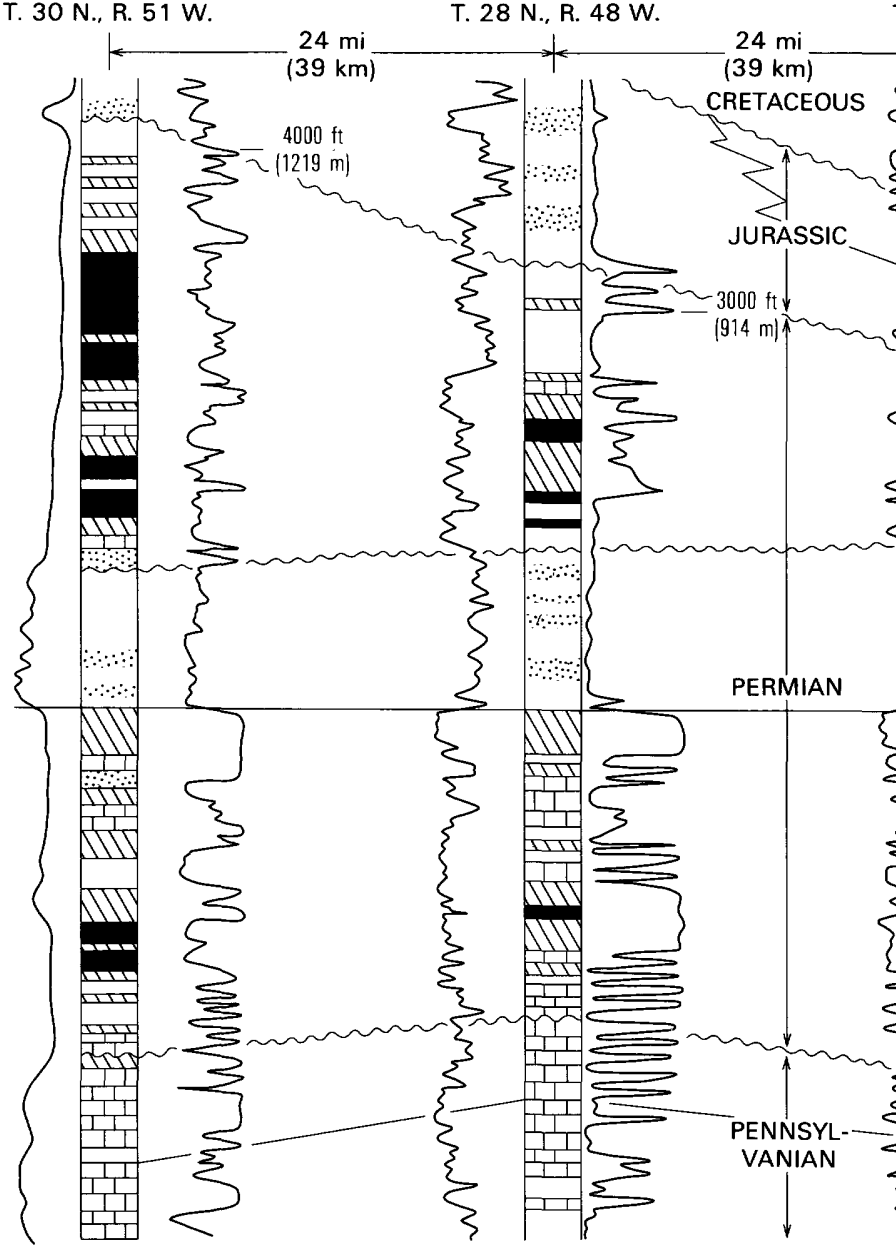

3

Sec. 20 ,

T. 26 N., R. 44 W.

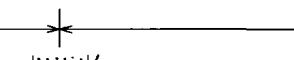

$37 \mathrm{mi}$
$(60 \mathrm{~km})$

Dakota Group

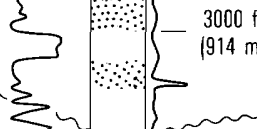

$\sum_{2}^{3}$
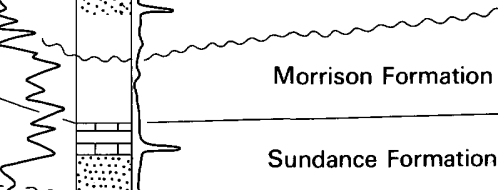

$\sum$ Goose Egg Formation

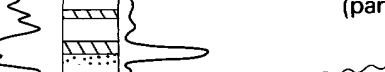

ह

$\{$ Leonardian

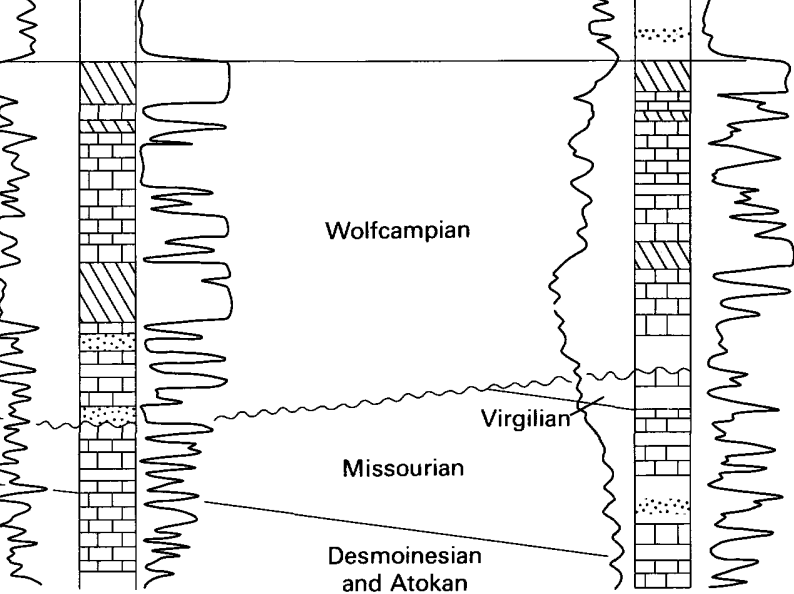

\section{EXPLANATION}

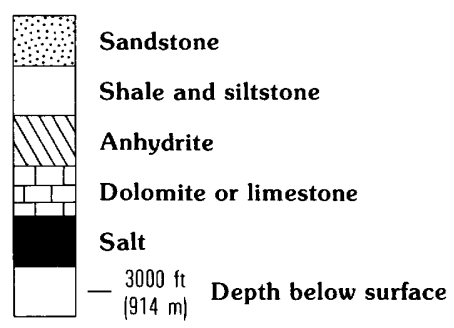

Sec. 28 ,
T. 21 N., R. 41 W. 


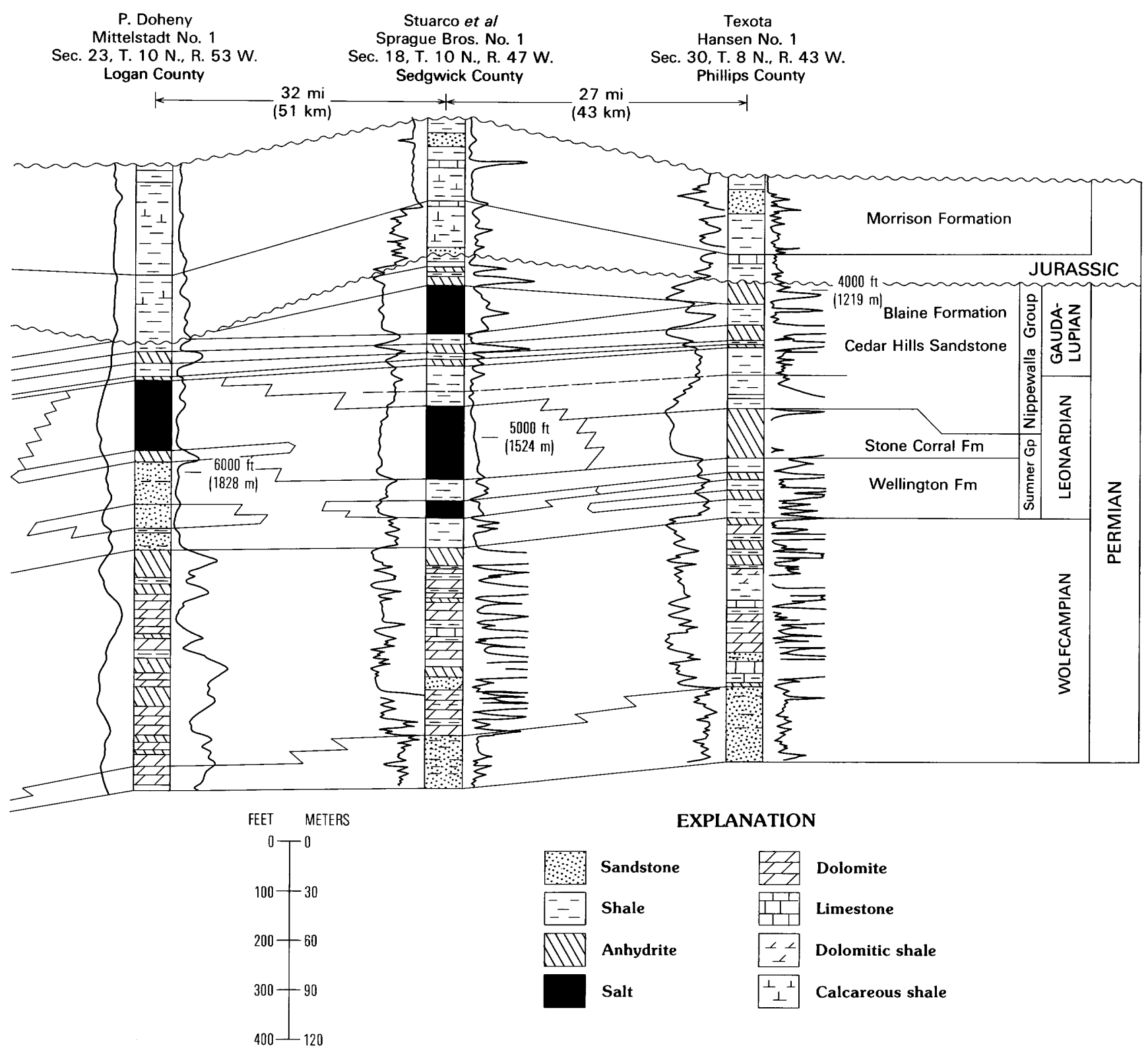

Figure 2.45. Columnar section of Permian, Jurassic, and Lower Cretaceous strata in Colorado part of northern Denver basin showing thick anhydrite reported in the Stone Corral Formation (modified from Irwin, 1977).

\section{WYOMING BASINS-PENNSYLVANIAN THROUGH JURASSIC}

Pennsylvanian through Jurassic strata in most of the Wyoming basins contain thin to moderately thick interbeds of anhydrite. Anhydrite-bearing units include the Minnelusa (Pennsylvanian and Lower Permian), Goose Egg (Permian and Lower Triassic), Phosphoria (Permian), Spearfish (Permian and Triassic), Gypsum Spring (Jurassic), and Preuss (Jurassic) Formations. Individual anhydrite beds are typically 2-10 m thick, although the Gypsum Spring Formation reportedly contains beds of anhydrite or gypsum that are as much as $30 \mathrm{~m}$ thick.

The present-day basins and uplifts of Wyoming (fig. 2.46) were not present during, and did not have a significant impact upon, evaporite sedimentation in the region. Anhydrite was deposited as interbeds with clastics and some carbonates during the late Paleozoic and early Mesozoic in shelf, shallow-marine, and low-relief continental environments that extended across large areas. Major sedimentary basins at that time were to the west and southeast of Wyoming. 

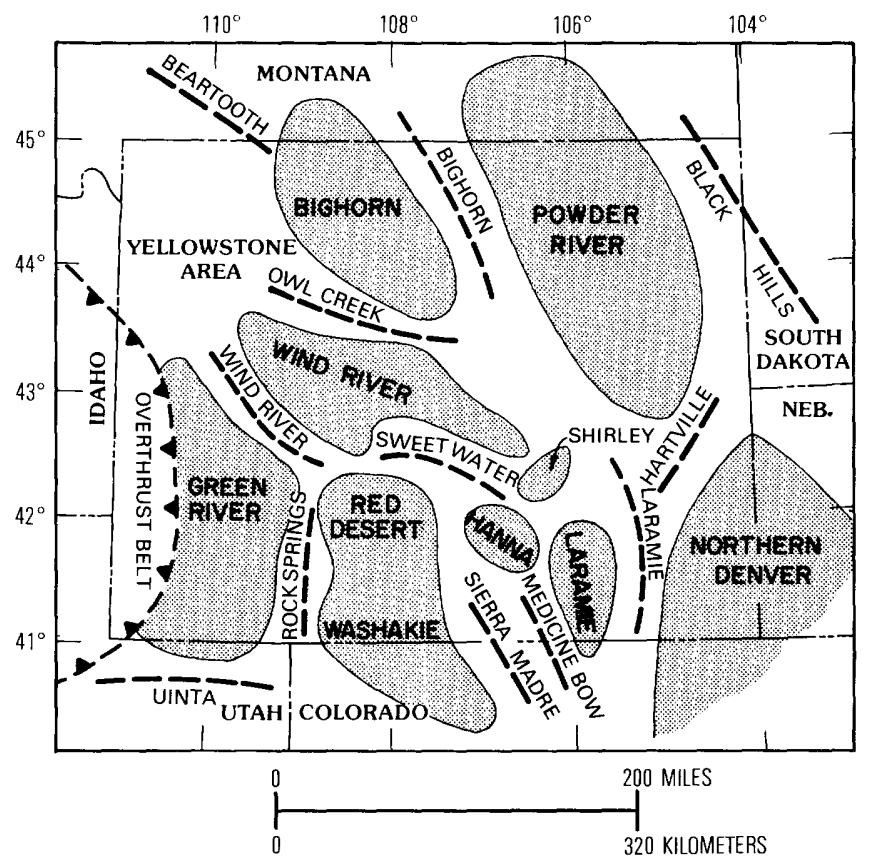

EXPLANATION

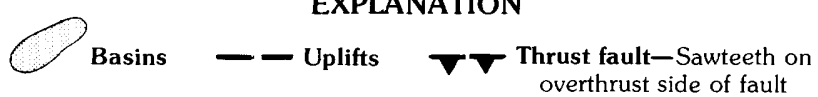

Figure 2.46. Map showing major basins and uplifts in Wyoming and adjacent areas.

Development of the Wyoming basins as structural features occurred mainly during tectonic movements in Late Cretaceous and early Tertiary time. Paleozoic and Mesozoic rocks were uplifted, broadly folded, and block faulted to form the principal mountain ranges of Wyoming and adjacent areas (fig. 2.46). These same strata were later buried beneath a thick sequence of Tertiary continental sediments. As much as 5,000-9,000 m of sedimentary rocks overlie the Precambrian basement in various basins in Wyoming, and the anhydrite-bearing strata are commonly $300-4,500 \mathrm{~m}$ below the land surface in these basins.

The Minnelusa Formation contains thin beds of anhydrite in the Powder River basin of eastern Wyoming and also in the area to the south and east of the Black Hills in South Dakota. The Minnelusa consists mainly of carbonates and sandstone in this region, but anhydrite beds $2-10 \mathrm{~m}$ thick also are present mainly in the upper member, which is of Permian age. The top of the Minnelusa is less than $1,000 \mathrm{~m}$ deep in most of the South Dakota area and is as much as 2,000-4,500 $\mathrm{m}$ deep in the Powder River basin. Anhydrite crops out at some localitics (Brady, 1958) and probably makes up most of the sulfatc at depths greater than $15 \mathrm{~m}$. Principal references on the geology and evaporites of the Minnelusa Formation are Brady (1958), Foster (1958), Smith (1967), Kinnison (1971), and Rascoe and Baars (1972).

The Goose Egg and Phosphoria Formations are typically $100-250 \mathrm{~m}$ thick in various Wyoming basins. Evaporites are more prominent in the Goose Egg than in the Phosphoria, and they occur chiefly in the Powder River and Wind River basins (fig. 2.46), and to a lesser extent in the Hanna, Shirley, Laramie, and Big Horn basins (Lane, 1973). Work on the evaporites of the Goose Egg and Phosphoria Formations has been done by Privrasky and others (1958), Campbell (1962), McKee, Oriel, and others (1967a, 1967b), Rascoe and Baars (1972), and Lane (1973).

The Goose Egg Formation consists mainly of red beds interbedded with anhydrite, limestone, dolomite, and (in the Powder River basin) salt. These strata were deposited around the northwestern margin of the large evaporite basins in the midcontinent (the Permian basin and the northern Denver basin). The Phosphoria Formation, on the other hand, was deposited on the shallow eastern shelf of a north-south trough that extended through Idaho and Utah. The Phosphoria Formation consists mainly of dolomites interbedded with limestone, phosphorite, clastics, and a few beds of anhydrite that are tongues extending westward from the Goose Egg Formation.

Individual anhydrite beds in the Goose Egg Formation are typically $2-10 \mathrm{~m}$ thick, and locally some are as much as $15 \mathrm{~m}$ thick (Lane, 1973). Named members that are characterized by anhydrite beds in the subsurface are the Minnekahta (its equivalent, the Sybille), Forelle, and Ervay Members. Even in these members, however, the anhydrites are thin and are interbedded with shale. Sulfate beds in the Goose Egg crop out as gypsum on the flanks of the basins in eastern and central Wyoming. They undoubtedly are represented by anhydrite at depths greater than $15-30 \mathrm{~m}$ and dip to depths of $2,000-4,500 \mathrm{~m}$ in various basins.

The Spearfish Formation, which crops out around the perimeter of the Black Hills, is a sequence of red beds and evaporites and is in part equivalent to the Goose Egg Formation of the Powder River basin. Gypsum and (or) anhydrite beds of the Spearfish are 2-10 m thick in the area around the Black Hills and extend from outcrops to depths of 2,000 m. Information on the Spearfish evaporites in this region was presented by Maughan (1966), Bailey and Roscoe (1972), and MacLachlan (1972).

The Gypsum Spring Formation consists mainly of clastics and carbonates, but a persistent bed of anhydrite (gypsum at and near the outcrop) is interbedded with those rocks in the northwestern quarter of Wyoming 


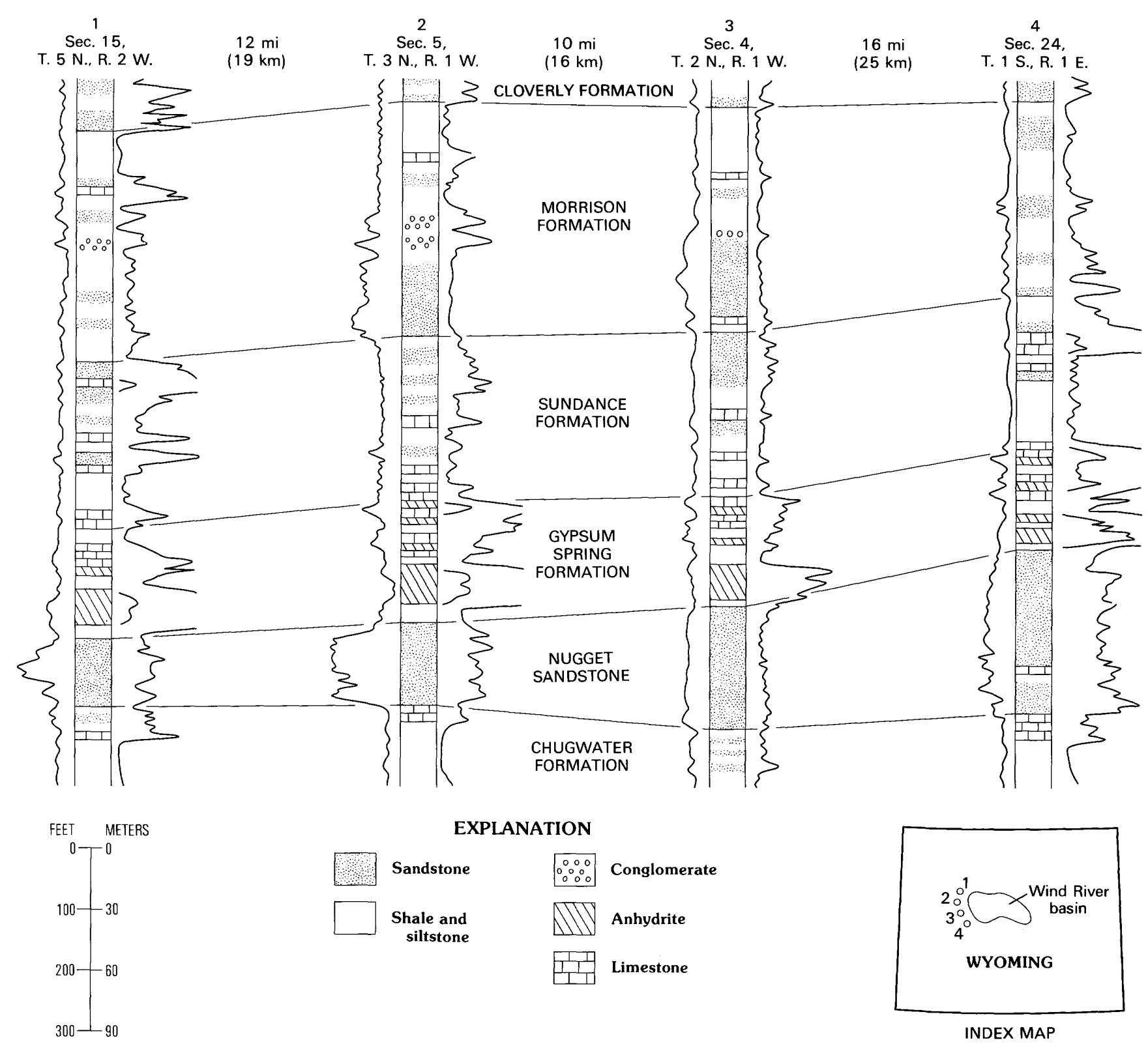

Figure 2.47. Stratigraphic cross section showing Gypsum Spring Formation and adjacent strata in western part of Wind River basin of Wyoming (modified from Burk and others, 1956). Horizontal distances not to scale. Index map shows location of wells.

(fig. 2.47). The principal areas underlain by anhydrite in this formation include parts of the Wind River, Bighorn, and Green River basins, and the flanks of some of the adjacent uplifts (fig. 2.46). Thickness of the entire formation is typically about $60-90 \mathrm{~m}$ in these basins, but, toward the southeast, the unit thins and is truncated by the overlying Sundance Formation. The anhydrite bed is reported to be $15-38 \mathrm{~m}$ thick in various areas (Love and others, 1945; Burk and others, 1956); it consists mostly of anhydrite, but in some areas contains thin layers of red beds or other nonsulfate strata. Data on the Gypsum Spring evaporites have been presented by Love and others (1945), Love (1948), Burk and others (1956), Peterson (1957a, 1972), and Bullock and Wilson (1969). However, few data are readily available on the variation in thickness of the anhydrite and on the presence or absence of these interbedded strata.

Depth to the top of anhydrite in the Gypsum Spring Formation ranges from less than $100 \mathrm{~m}$ along the flanks of the basins to as much as 4,500-5,000 $\mathrm{m}$ in the deep basins. The anhydrite unit is $300-1,500 \mathrm{~m}$ below the surface only on the upper (shallow) flank areas of the Wind River and Bighorn basins and adjacent uplifts. Anhydrite beds dip gently (as much as about $5^{\circ}$ ) on the 


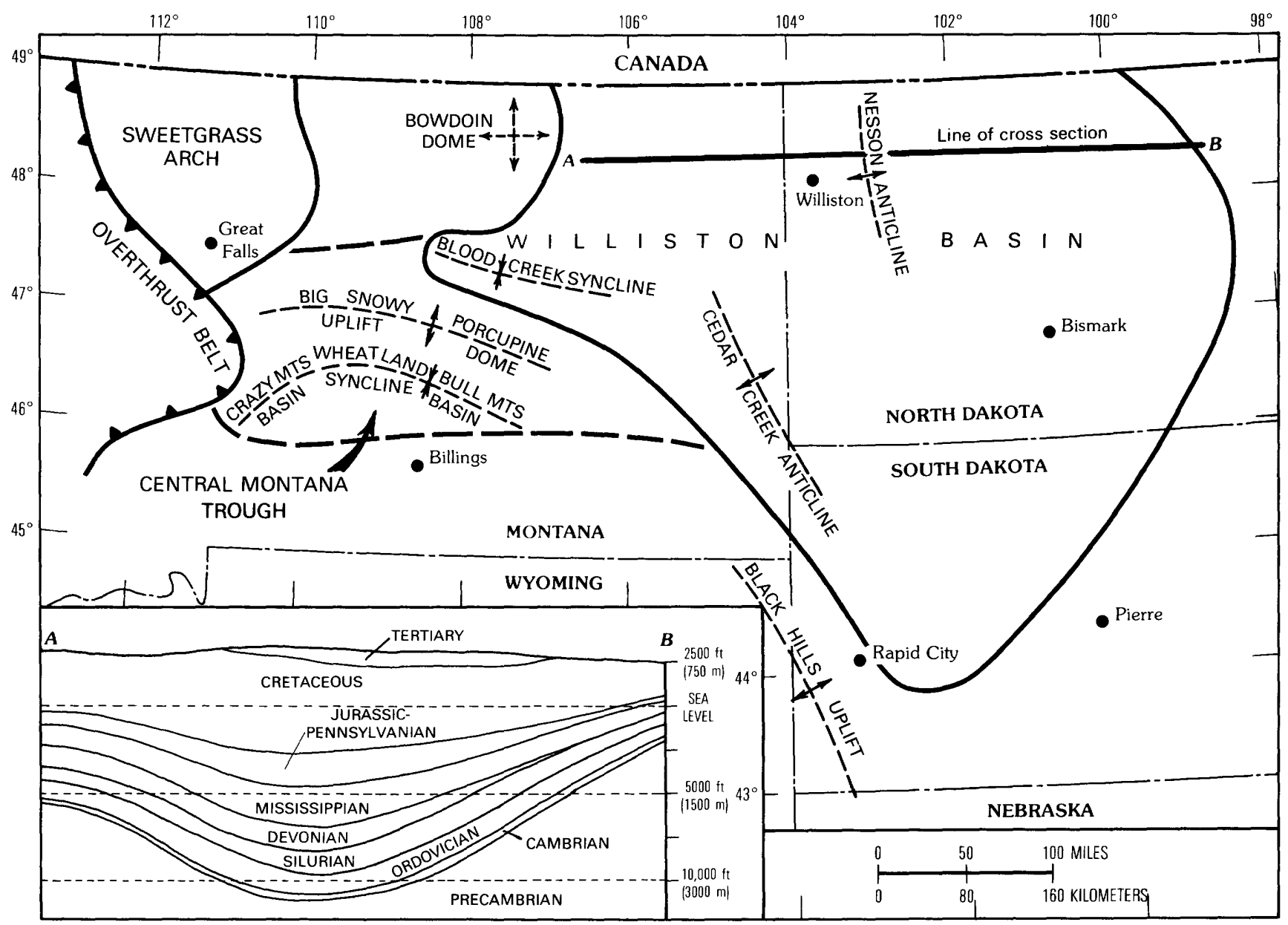

EXPLANATION

Thrust fault-Sawteeth on
overthrust side of fault

Figure 2.48. Map of Williston basin area in northwestern United States showing principal structural features adjacent to the basin and location of the central Montana trough (cross section modified from Reed, 1963).

southwestern side of the Wind River basin and locally around the south and east flanks of the Bighorn basin; elsewhere in the region, the basin margins are structurally more complex and faults, tight folds, and steep dips are present. Additional study is needed to determine the character, thickness, and depth of the Gypsum Spring anhydrite in the generally undisturbed areas of the Wind River and Bighorn basins where the unit is known to be at moderate depths.

To the southwest, in the Idaho-Utah-Wyoming stateline area, the Gypsum Spring Formation and the younger Jurassic Preuss Sandstone contain thin anhydrite interbeds at depths ranging between 1,500 and 3,000 m (Burk and others, 1956; Peterson, 1957a; Maher, 1976). The structure of the anhydrite beds here is complicated because of intense folding and faulting within the overthrust belt just west of the Green River basin.

\section{WILLISTON BASIN-ORDOVICIAN THROUGH JURASSIC}

A number of Paleozoic and Mesozoic formations contain anhydrite in the Williston basin, a large sedimentary and structural basin that underlies most of North Dakota, eastern Montana, northwestern South Dakota, and part of southern Canada (fig. 2.48). Strata dip gently at an angle less than $l^{\circ}$ toward the depocenter of the basin where a sequence of about $5,000 \mathrm{~m}$ of 
sedimentary rock of Cambrian through Tertiary age is preserved (Carlson and Anderson, 1965). Major structural features in the basin are the Nesson anticline, a north-trending structure in northwestern North Dakota, and the Cedar Creek anticline, a structure that extends northwestward into Montana from the common corner of North Dakota, South Dakota, and Montana. An elongate locus of deposition, referred to as the central Montana trough, extends westward from the Williston basin. This area contains a thick sequence of evaporitebearing Mississippian strata that is best discussed here with sediments of the Williston basin. An earlier study of the Williston basin by Sandberg (1962) discussed the potential for subsurface disposal of radioactive wastes.

Anhydrite-bearing formations were deposited in the Williston basin during each geologic period from the Ordovician through the Jurassic (fig. 2.49). In most of the formations the anhydrite beds are 2-10 m thick and are $1,200 \mathrm{~m}$ to more than $2,000 \mathrm{~m}$ deep. The maximum reported thicknesses are $15 \mathrm{~m}$ in the Devonian Prairie Formation and $25-30 \mathrm{~m}$ in the Mississippian Madison Group.

A series of thin anhydrite beds are present in the Ordovician Red River and Stonewall Formations, and in the Silurian Interlake Formation (Fuller, 1961; Smith, 1967; Ballard, 1969). Total thickness of these anhydritebearing strata ranges from about $60-120 \mathrm{~m}$ in the interior of the basin, and the individual anhydrite beds range from 1 to $6 \mathrm{~m}$ in thickness. Depths to tops of anhydrite beds are 2,400-4,000 $\mathrm{m}$ below the surface.

Devonian strata contain thin anhydrite beds at several stratigraphic levels, including (in ascending order) the Winnipegosis, Prairie, Dawson Bay, Souris River, Duperow, Birdbear, and Three Forks Formations (Andrichuk, 1951; Sandberg and Hammond, 1958; Sandberg, 1961; Smith, 1967; Sandberg and Mapel, 1967). In most formations the anhydrite beds are typically 2-10 m thick and are from 1,500-4,000 m deep. Anhydrite beds in the Prairic Formation reach a maximum thickness of about $15 \mathrm{~m}$ at a depth of about $2,700 \mathrm{~m}$ in Divide County, N. Dak. (Smith, 1967). The Prairie Formation reaches a maximum total thickness of nearly $150 \mathrm{~m}$ at the depocenter of the basin where it consists almost entirely of bedded halite and several interbeds of anhydrite and potash salts.

Anhydrite also is present at a number of stratigraphic levels in the Mississippian Madison Group (fig. 2.49). It occurs chiefly in the Charles Formation, but also is present in the upper part of the underlying Mission Canyon Limestone (Smith and others, 1958; Andrichuk, 1958; Maher, 1960; Smith, 1967; Cook, 1976). The principal area of anhydrite deposition was in the main part of the Williston basin, but anhydrite also was deposited in a second evaporite province that extended westward along the axis and shelf areas of the central
Montana trough (Andrichuk, 1958; Craig, 1972). In the main part of the Williston basin, the anhydrite beds are typically 2-10 m thick and range from about 3,000 m deep in the basin center to about 1,200 m deep around the perimeter. Marafi (1972), however, referred to an anhydrite bed about $25 \mathrm{~m}$ thick at a depth of $1,100 \mathrm{~m}$ in Bottineau County, N. Dak., on the northeastern side of the basin. In the central Montana trough, in and around the Big Snowy uplift and Blood Creek syncline, the lower part of the Charles Formation is reported to contain anhydrite beds as much as $30 \mathrm{~m}$ thick at depths of about 1,000-1,500 m (Maher, 1960). Blankennagel and others (1979) reported about $35 \mathrm{~m}$ of anhydrite and some interbedded dolomite in undifferentiated Madison strata at a depth of about $1,400 \mathrm{~m}$ in a well in south-central Montana.

The Big Snowy Group also contains thin beds of gypsum and anhydrite deposited in the Williston basin and the central Montana trough (Mundt, 1956; Rawson, 1969; Craig, 1972). Formations containing anhydrite include, in ascending order, the Kibbey, Otter, and Heath; thicknesses of individual anhydrite beds range from 2 to $10 \mathrm{~m}$. Some of the sulfate beds crop out as gypsum on the flanks of uplifts in Fergus, Judith Basin, Cascade, and Meagher Counties (Perry, 1949), but all exist as anhydrite where they dip into nearby basins and synclines to depths of $300-1,500 \mathrm{~m}$.

The Pennsylvanian, Permian, Triassic, and Jurassic Systems contain thin anhydrite beds in the Williston basin (fig. 2.49). Individual anhydrite units are $2-10 \mathrm{~m}$ thick, and typically occur at depths ranging from 1,200 to 2,000 $\mathrm{m}$. Formations containing anhydrite include, in ascending order, the Minnelusa, Opeche, Minnekahta, Spearfish, and Piper; these units were discussed by Francis (1957), Peterson (1957b), Maughan (1966), Dow (1967), Smith (1967), Mallory (1972), Rascoe and Baars (1972), and MacLachlan (1972).

\section{SWEETGRASS ARCH-THREE FORKS FORMATION AND OTHER DEVONIAN UNITS}

Upper Devonian strata in the Sweetgrass arch area of northwest Montana (fig. 2.48) comprise a thick sequence of carbonates and evaporites. Anhydrite beds in the sequence typically are 3-10 m thick, but the Logan Gulch Member of the Three Forks Formation at the top of the sequence contains anhydrite beds as much as $30 \mathrm{~m}$ thick at depths of $600-1,500 \mathrm{~m}$. Other Devonian stratigraphic units that contain thinner anhydrite beds include the Souris River and Duperow Formations. Detailed studies of anhydrites in the Sweetgrass arch area have not 


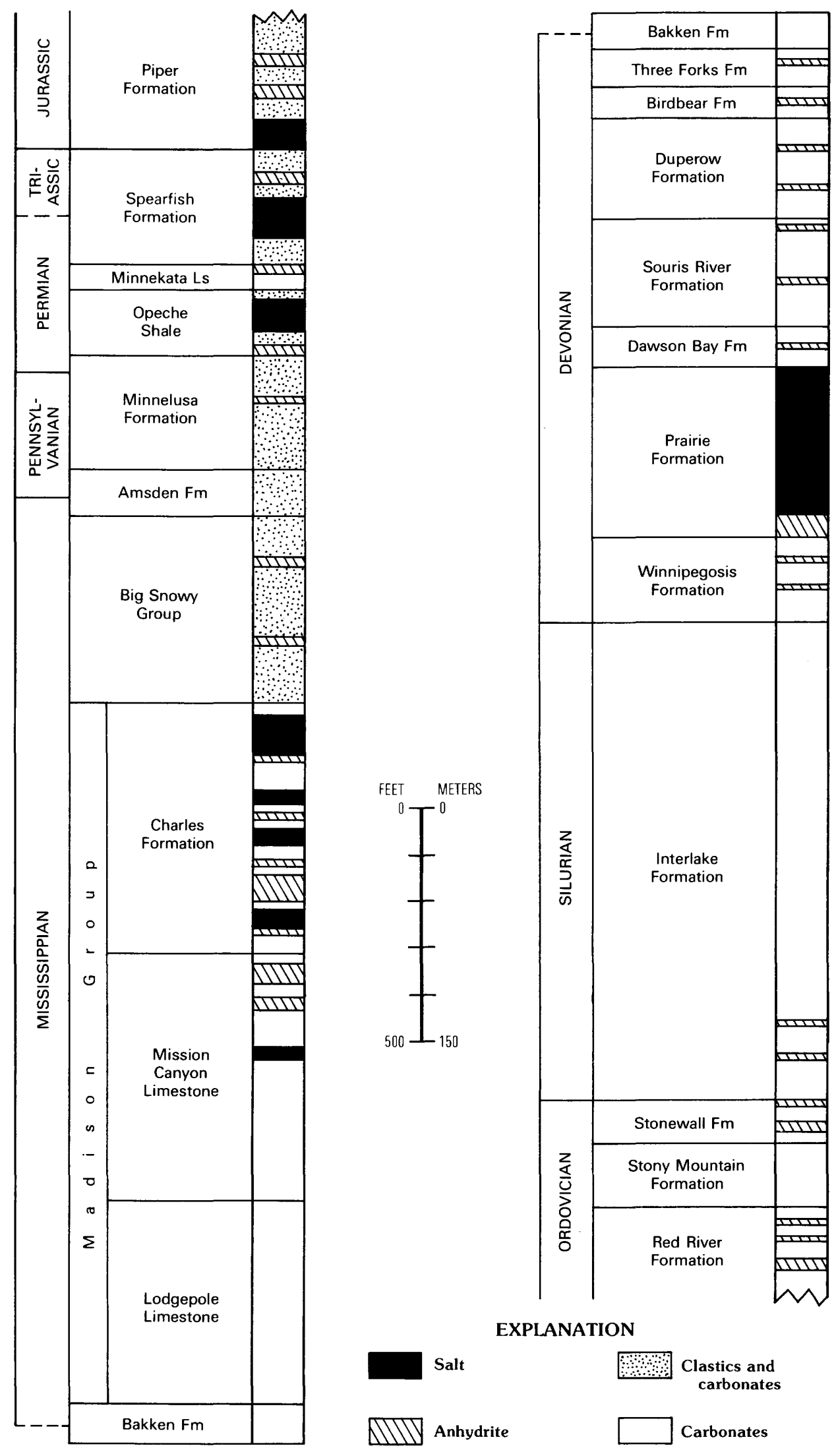

Figure 2.49. Generalized columnar section of the Williston basin showing evaporite units in Ordovician through Jurassic strata (modified from Smith, 1967; Dow, 1967). 
been published, but general data on Devonian strata of the region, and some information on the evaporites, have been released by Sloss and Laird (1947), Andrichuk (1951), Belyea (1958), Billings Geological Society (1962), Peterson (1966), Sandberg and Mapel (1967), Baars (1972), and Sandberg and Poole (1977).

During Late Devonian time, the Sweetgrass arch was connected with the Williston basin to the north and east, and some of the rock units are western extensions of those previously described in the Williston basin. Total thickness of Upper Devonian strata in the Sweetgrass arch area ranges from about $150 \mathrm{~m}$ in the southeast to about $450 \mathrm{~m}$ in the northwest (Sandberg and Mapel, 1967). Since Devonian time, thick sequences of Jurassic and Cretaceous strata have been deposited, along with thinner sequences of other systems; the region is now characterized as undeformed and has gentle dips and few minor structures. The western boundary of the arch is the structurally complex overthrust belt along the Northern Rocky Mountain front. Petroleum now is being produced from a number of Mississippian through Cretaceous reservoirs at many locations over the arch.

The Souris River and Duperow Formations consist mostly of dolomite and lesser amounts of interbedded anhydrite and limestone (fig. 2.50). Individual anhydrite beds are typically 3-10 $\mathrm{m}$ thick and are distributed throughout both formations at depths ranging from $600-1,500 \mathrm{~m}$.
1

Renwar Oil Co.

No. 1 McKechnie Sec. 1, T. 31 N., R. 1 W.

L

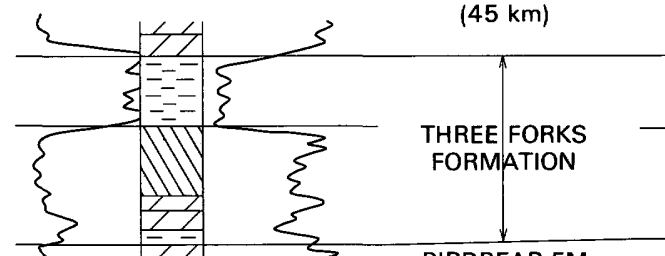

2

Montalban Oils Inc.

No. 1 Johnson

Sec. 7, T. 27 N., R. 2 W.
3

General Petroleum Corp.

No. 88-30-P Holt

Sec. 30, T. 25 N., R. 1 W.

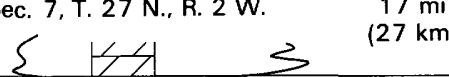

BIRDBEAR FM
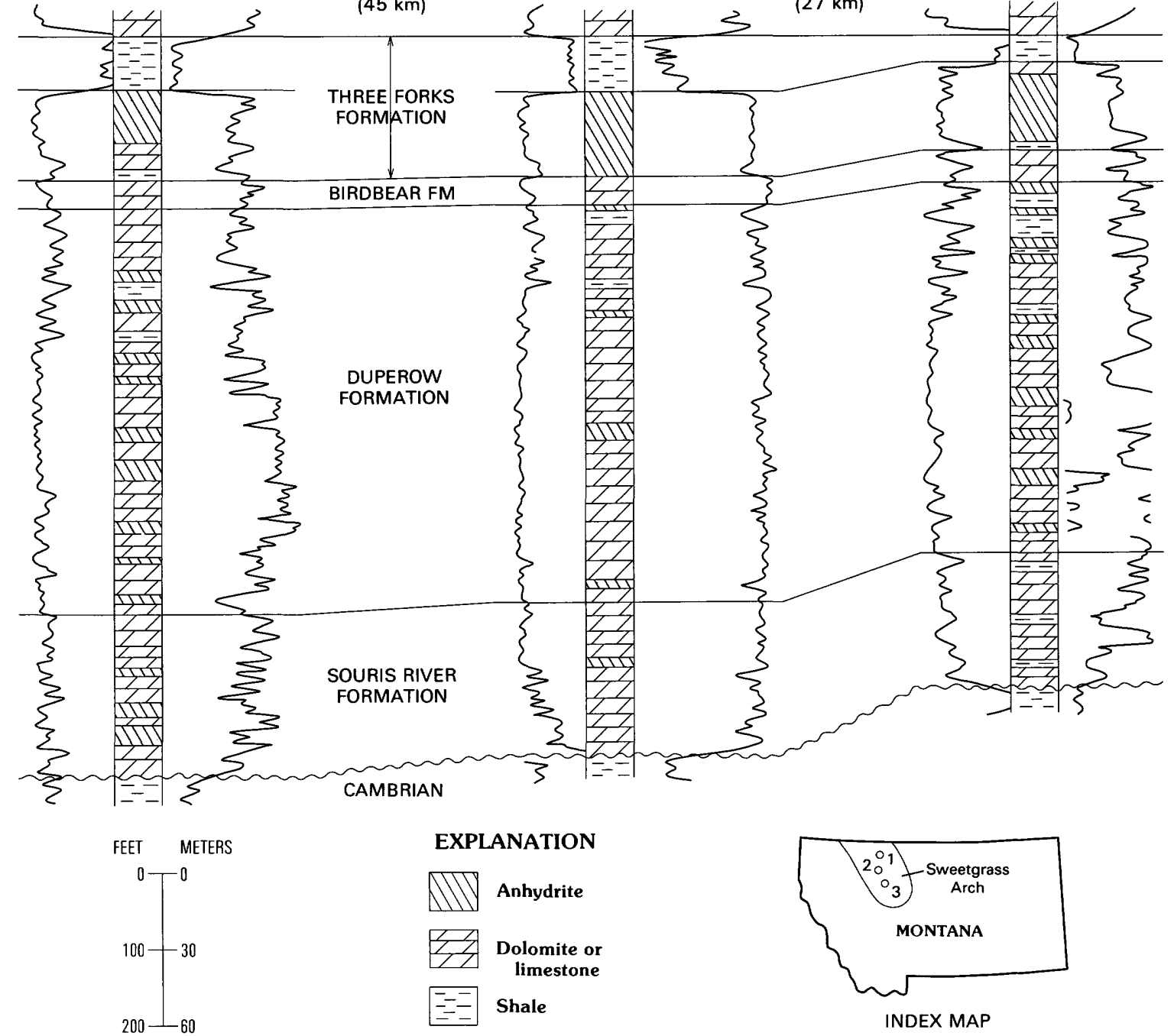

EXPLANATION

Anhydrite

Shale

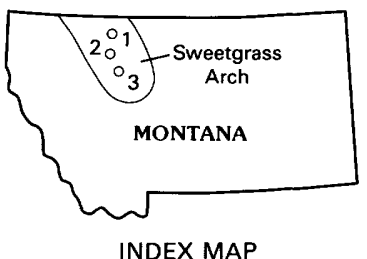

Figure 2.50. Stratigraphic cross section of Sweetgrass arch area showing Three Forks Formation and other anhydritic units of the Upper Devonian (modifed from Billings Geological Society, 1962). Horizontal distances not to scale. Index map shows location of wells. 
The principal anhydrite unit of the Sweetgrass arch area is the Logan Gulch Member of the Three Forks Formation (also referred to as the Potlatch Anhydrite). This unit ranges from about 30 to $120 \mathrm{~m}$ in thickness in the subsurface, and the thickness generally increases westward across the arch. Sandberg and Mapel (1967) referred the upper part of the Potlatch to the Logan Gulch Member of the Three Forks Formation and used the term Logan Gulch in central Montana, southwest Montana, and Wyoming.

Where the Logan Gulch anhydrite is thickest, it consists of anhydrite interbedded with lesser amounts of dolomite (C.A. Sandberg, oral commun., 1979). Individual anhydrite beds in this area and elsewhere range from $12-30 \mathrm{~m}$ in thickness, although one of the anhydrite beds may exceed $30 \mathrm{~m}$. Away from the western depocenter, there appears to be a single bed of anhydrite that ranges from 15 to $30 \mathrm{~m}$ in thickness (fig. 2.50). It is overlain by 5-20 m of gray calcareous shale, referred to as the Trident Member of the Three Forks Formation (Sandberg and Mapel, 1967). The depth to the top of the Logan Gulch anhydrite in the Sweetgrass arch area ranges from about $600 \mathrm{~m}$ along the crest of the arch to as much as $1,500 \mathrm{~m}$ on the east and west flanks.

In summary, anhydrite in the Sweetgrass arch area occurs only in a single rock unit, the Logan Creek Member, that has thick anhydrite beds at moderate depths. No detailed study has been made of this unit, however, and additional information is needed to assess more thoroughly the character, distribution, thickness, and depth of these anhydrite beds.

\section{EAGLE BASIN-EAGLE VALLEY EVAPORITE}

The Eagle Valley Evaporite is a thick sequence of Pennsylvanian strata on the western side of the Rocky Mountains in northwest Colorado (fig. 2.51). Eagle basin is the name generally used for this region, but the term Maroon basin has also appeared in the literature. Total thickness of the evaporite unit is as much as $3,000 \mathrm{~m}$, and anhydrite and (or) gypsum beds are as much as about $50 \mathrm{~m}$ thick. Salt also is present in the Eagle Valley Evaporite in the subsurface, and diapiric flow of the salt into anticlines is one of the causes for complex structures and deformation of the anhydrite (or gypsum) beds. Reports dealing with the evaporites in this area include those by Katich (1958), Mallory (1966, 1971, 1977), and Peterson and Hite (1969).

The Eagle Valley Evaporite was deposited in a landlocked marine trough between the Uncompahgre

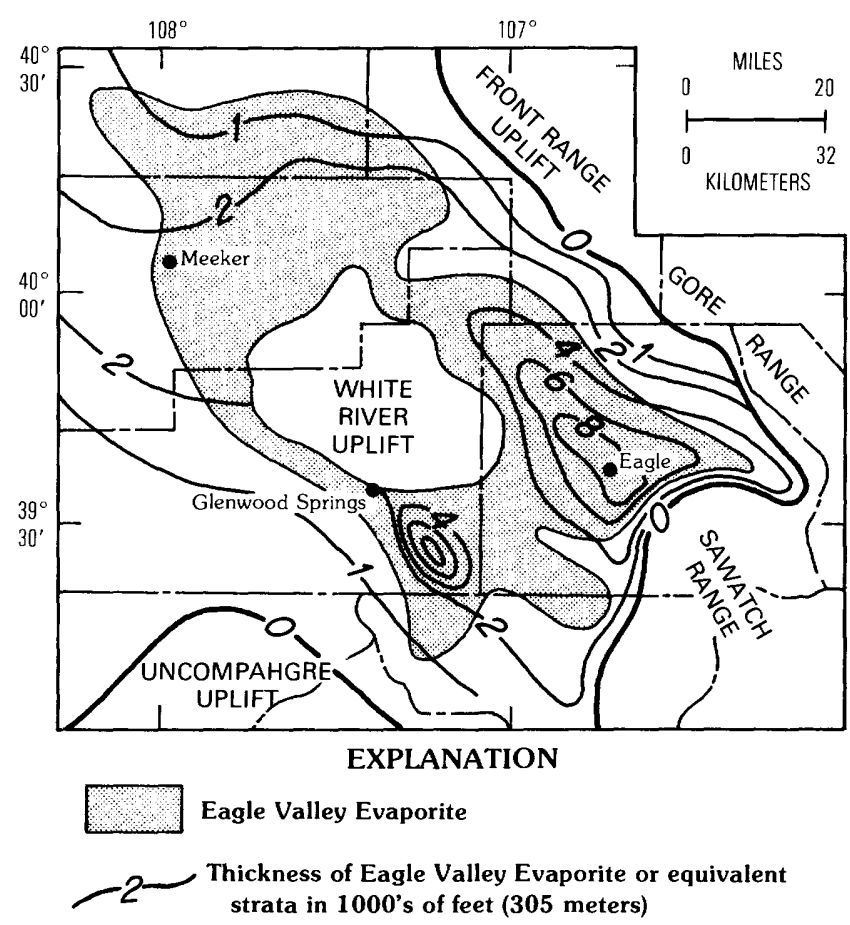

Figure 2.51. Distribution and thickness of Eagle Valley Evaporite in the Eagle basin of northwest Colorado (modified from Mallory, 1977).

and Front Range uplifts (fig. 2.51), and is restricted to an area about $80 \mathrm{~km}$ wide by $160 \mathrm{~km}$ long. The evaporites interfinger with red and maroon clastic sediments of the Middle Pennsylvanian (late Atokan and Desmoinesian) Minturn Formation.

The Eagle Valley Evaporite consists principally of gypsum and anhydrite interbedded with gray shale, siltstone, and sandstone. In the subsurface near the town of Eagle and southeast of Glenwood Springs (near Cattle Creek station), Colo., boreholes have penetrated a substantial thickness of rock salt interbedded in the unit (fig. 2.52); and potash salts also have been reported from the Eagle area. Outcrops of gypsum are widespread along and overlooking the valleys of Eagle and Colorado Rivers near their confluence; they are present also at scattered locations along Fryingpan River, Cattle Creek, Gypsum Creek, and on the south flank of the White River uplift (Mallory, 1971).

Thickness of the evaporite unit ranges from about $500 \mathrm{~m}$ around the perimeter of the basin to as much as 3,000 m near Eagle and Cattle Creek Station. Beds of gypsum and anhydrite are commonly 5-30 m thick and probably reach a thickness of $50 \mathrm{~m}$. Outcropping gypsum beds that are plastically deformed appear to be much more than $50 \mathrm{~m}$ thick. The depth to anhydrite probably ranges from a few meters in some outcrop areas to several thousand meters in the depocenters. Boreholes 


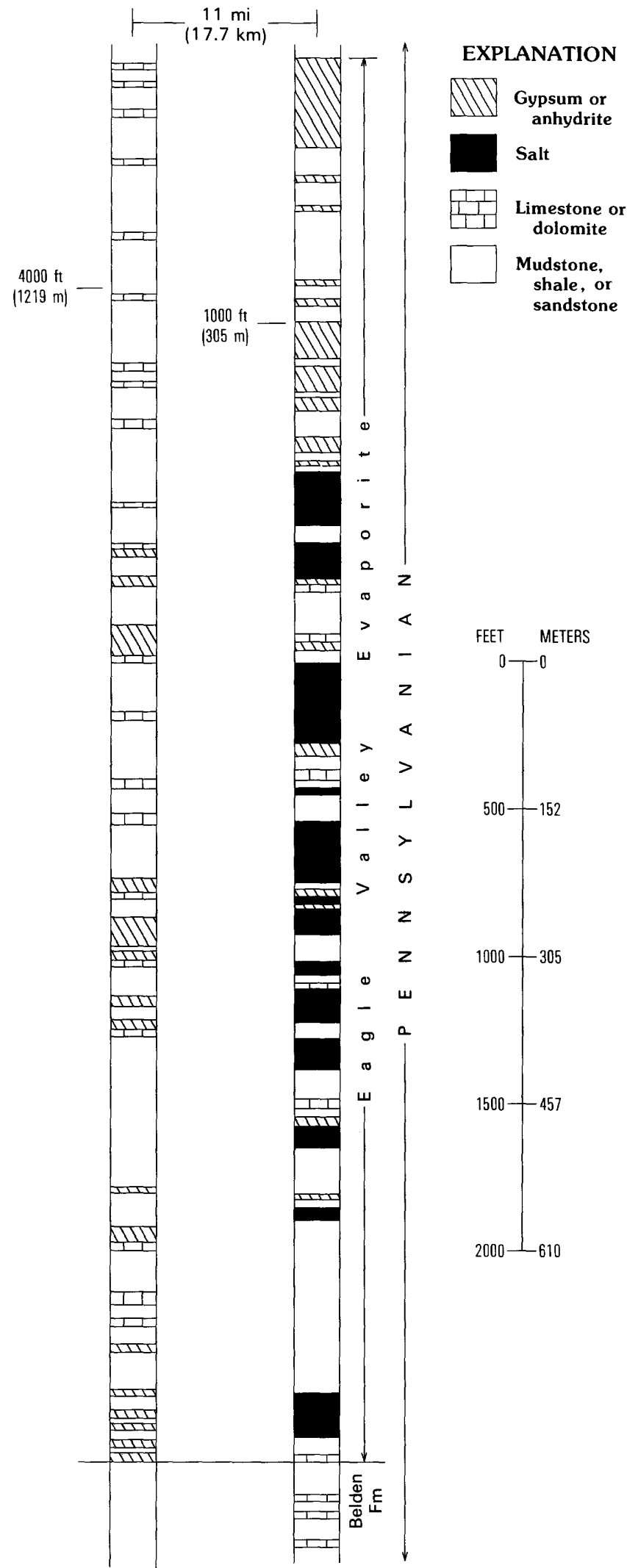

Figure 2.52. Lithology of the Eagle Valley Evaporite in two wells drilled in Eagle County, Colo. (modified from Irwin, 1977). Wells are California No. 1 Benton, sec. 14, T. 3 S., R. 85 W. (left), and Chaplin No. 1 Black, sec. 4, T. 5 S., R. 84 W. (right). drilled at Eagle, at Cattle Creek station, and at a site $15 \mathrm{~km}$ northwest of Eagle all penetrated anhydrite beds 5-30 m thick (fig. 2.52).

Since its deposition, the Eagle Valley Evaporite has been subjected to the following stresses: (1) load metamorphism, (2) Laramide orogenic movement, (3) growth of diapiric anticlines, and (4) local contortion from flowage and hydration of anhydrite (Mallory, 1971). Outcropping strata of the evaporate unit are deformed in most areas, and Mallory (1971) believed that the evaporite mass may still be rising within the cores of several anticlines.

Anhydrite units in the areas of thick evaporites probably have been deformed to such an extent that they are not likely to be suitable for long-term containment of radioactive waste. However, one or several of the anhydrite beds that interfinger with the Minturn Formation or the overlying Maroon Formation away from the evaporite depocenters may be sufficiently thick and undeformed to be potentially suitable for this purpose.

\section{PARADOX BASIN-PARADOX MEMBER OF HERMOSA FORMATION}

The Paradox basin of southeast Utah and southwest Colorado contains a thick sequence of salt deposits interbedded with shale, dolomite, anhydrite, and (locally) potash in the Paradox Member of the Hermosa Formation (Middle Pennsylvanian). Anhydrite beds range in depth from several hundred meters to several thousand meters, but the thickness of individual anhydrites typically ranges only from 3 to $10 \mathrm{~m}$ and probably does not exceed $15 \mathrm{~m}$. Along the crests of a series of salt-cored anticlines in the basin (fig. 2.53) is a thick cap rock that consists mainly of gypsum and anhydrite mixed in a jumbled mass with shale and dolomite.

Salt and other evaporites of the Paradox Member underlie an area of $30,000 \mathrm{~km}^{2}$ in the Paradox basin, but the greatest thickness of evaporites is in the troughlike depression adjacent to the Uncompahgre uplift on the north side of the basin. The original thickness of evaporites in the trough area is estimated to have been between 1,500 and 1,800 $\mathrm{m}$ (Hite and Lohman, 1973). Flowage of salt in the numerous diapiric salt anticlines has, however, caused the present thickness to range from 0 to more than $3,000 \mathrm{~m}$ in a horizontal distance of $5 \mathrm{~km}$ or less. The maximum thickness of evaporites in the salt anticlines is nearly $4,200 \mathrm{~m}$. Recent references on the general geology of this evaporite sequence include the work of Hite (1960, 1968, 1970), Elston and Shoemaker (1961), Hite and Lohman (1973), and Johnson and Gonzales (1978).

The evaporites of the Paradox Member consist of a sequence of cyclic sediments that include black shale, dolomite, anhydrite, halite, and (in some cycles) potash 


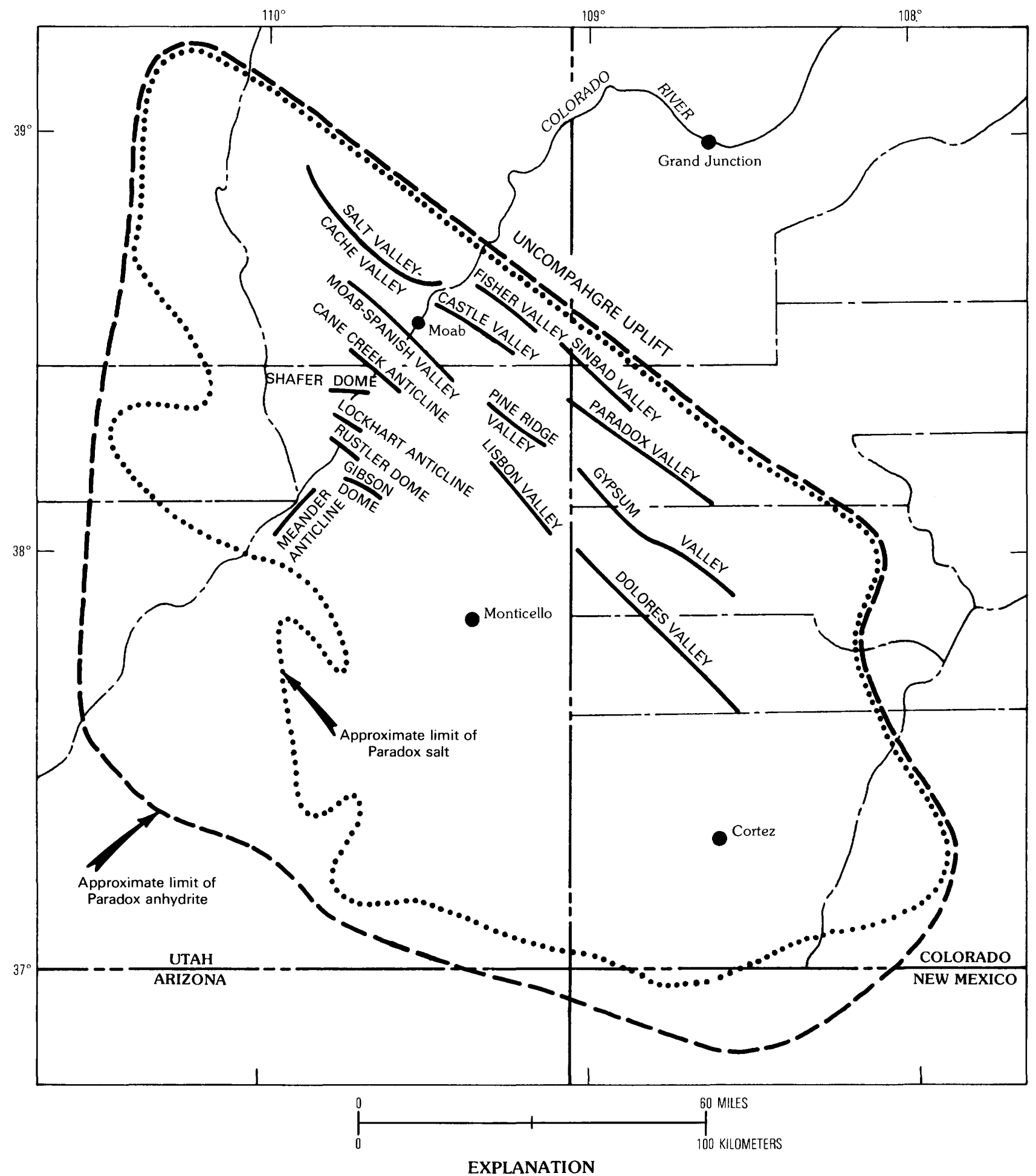

Salt anticline or salt dome

Figure 2.53. Index map of Paradox basin showing distribution of Paradox evaporites and location of salt anticlines in northeastern part of basin (modified from Hite and Lohman, 1973).

(fig. 2.54). A total of 29 evaporite cycles has been recognized in the deeper parts of the basin, and these have been numbered 1 through 29 in descending order (Hite, 1960; Hite and Liming, 1972; Hite and Lohman,
1973). Each evaporite cycle can be correlated for considerable distances across the basin, although correlation is difficult where beds have been folded, faulted, and deformed by flowage into the salt anticlines. 
Individual evaporite cycles are commonly 30-100 m thick, and salt is the dominant rock type in almost all areas. The aggregate thickness of just the black shaledolomite-anhydrite part (called the marker beds) of each cycle is typically $10-20 \mathrm{~m}$, and the thickness of individual anhydrite beds ranges from 3-10 m (fig. 2.54). More complete discussion of the evaporites and evaporite cycles was given by Herman and Sharps (1956), Herman and Barkell (1957), Hite (1968, 1970, 1977), Peterson and Hite (1969), and Hite and Lohman (1973).

The major structural features of the Paradox basin are the salt-cored anticlines in the troughlike depression on the northeastern side of the basin. The anticlines, which occupy an area about $80 \mathrm{~km}$ wide and $200 \mathrm{~km}$ long, consist of long, undulating welts of thickened salt (figs. 2.55 and 2.56) over which the younger rocks are arched (Shoemaker and others, 1958; Cater, 1970; Hite and Lohman, 1973). Five major anticlinal systems are in the basin; separate names have been given to the more pronounced segments of each system where the anti-

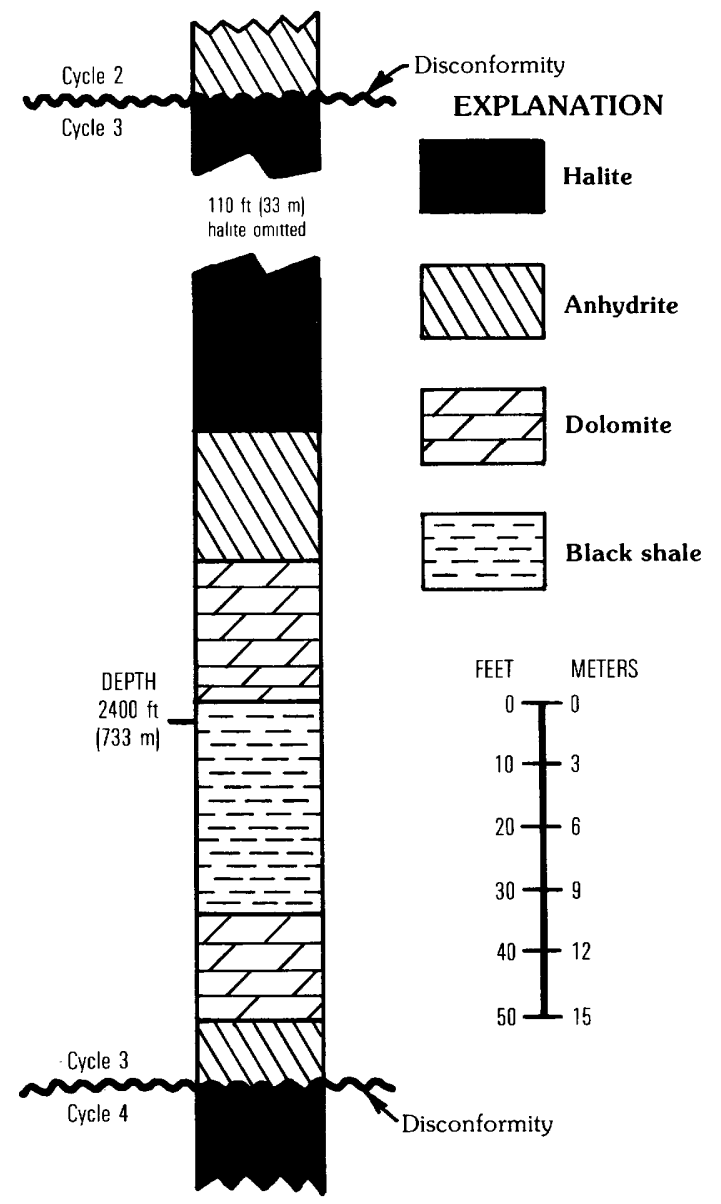

Figure 2.54. Typical evaporite cycle of the Paradox Member of the Hermosa Formation (modified from Hite and Lohman, 1973). clines are breached and where the surface expression is a prominent flat-floored valley that exposes gypsum and other rocks. The principal salt-anticline systems are: (1) Lisbon Valley-Dolores Valley, (2) Moab Valley-Spanish Valley-Pine Ridge, (3) Gypsum Valley, (4) Castle ValleyParadox Valley, and (5) Salt Valley-Cache Valley-Fisher Valley-Sinbad Valley (fig. 2.53). Several smaller anticlines or domes that lie just southwest of Moab, Utah, along the Colorado River include Cane Creek anticline, Shafer dome, Lockhart anticline, Rustler dome, Gibson dome, and Meander anticline.

Dissolution of halite at the upper surface of the thickened salt core has caused local development of a cap rock of insoluble material as much as several hundred meters thick along the crest of the salt anticlines (Hite and Lohman, 1973) (fig. 2.56). Cap rock in this region differs somewhat from that on Gulf Coast salt domes. The Gulf Coast variety was formed entirely from thin laminae and small crystals of anhydrite disseminated in the halite, whereas the Paradox basin cap rock includes this type of anhydrite and even greater amounts of insoluble black shale, dolomite, and anhydrite from the marker beds. Because of dissolution of interbedded salt and collapse of the various marker beds, the cap rock is generally chaotic and consists of a jumbled mass. The cap rock is generally porous, and in some anticlines all or part of it is saturated with brine (Hite, 1977). Most anhydrite originally present in the cap rock has been converted to gypsum.

In an earlier appraisal of the Paradox basin for emplacement of radioactive wastes in salt deposits, Hite and Lohman (1973) concluded that the Salt Valley anticline and the Shafer dome had some potential for this use. Further study by the U.S. Geological Survey has centered on an evaluation of the geology, hydrology, mineral resources, and geothermal gradient of the north end of the Salt Valley anticline (Gard, 1976; Hite, 1977).

\section{SAN JUAN BASIN-TODILTO FORMATION}

A thick bed of anhydrite in the Todilto Formation (Middle Jurassic) is present in the subsurface in the eastern half of the San Juan basin of northwestern New Mexico and part of adjacent Colorado (fig. 2.57). This bed is typically $25-30 \mathrm{~m}$ thick, and may be as much as $40 \mathrm{~m}$ thick, and its depth below the surface ranges from less than $100 \mathrm{~m}$ in the southeastern part of the basin to 2,700 $\mathrm{m}$ in the northeastern part. The bed crops out as gypsum on the southern and eastern sides of the basin. Studies of the Todilto gypsum-anhydrite unit include those by Weber and Kottlowski (1959), Anderson and 


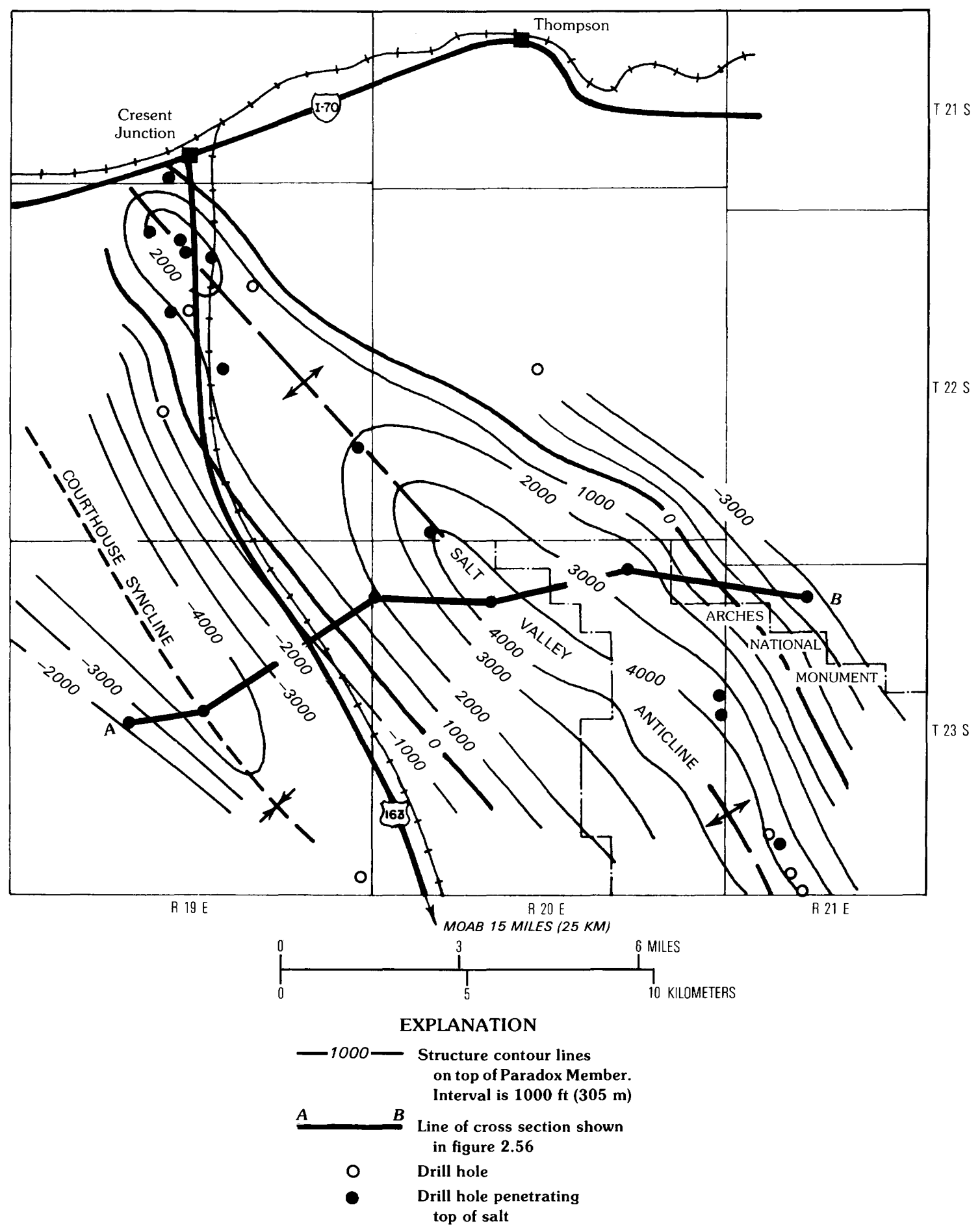

Figure 2.55. Structure-contour map on top of salt in Paradox Member of Hermosa Formation along Salt Valley anticline, Grand County, Utah (modified from Hite and Lohman, 1973).

Kirkland (1960), Tanner (1970, 1972), and Stapor (1972); regional summaries of the Jurassic System and the San Juan basin can be found in Peterson and others (1965), Santos (1975), Green and Pierson (1977), and Woodward and Callender (1977).
The San Juan basin, in the eastern part of the Colorado Plateau, consists mainly of gently dipping strata that are only moderately deformed, mainly along the perimeter. The basin is nearly circular in plan and is strongly asymmetrical in cross section. Principal uplifts 


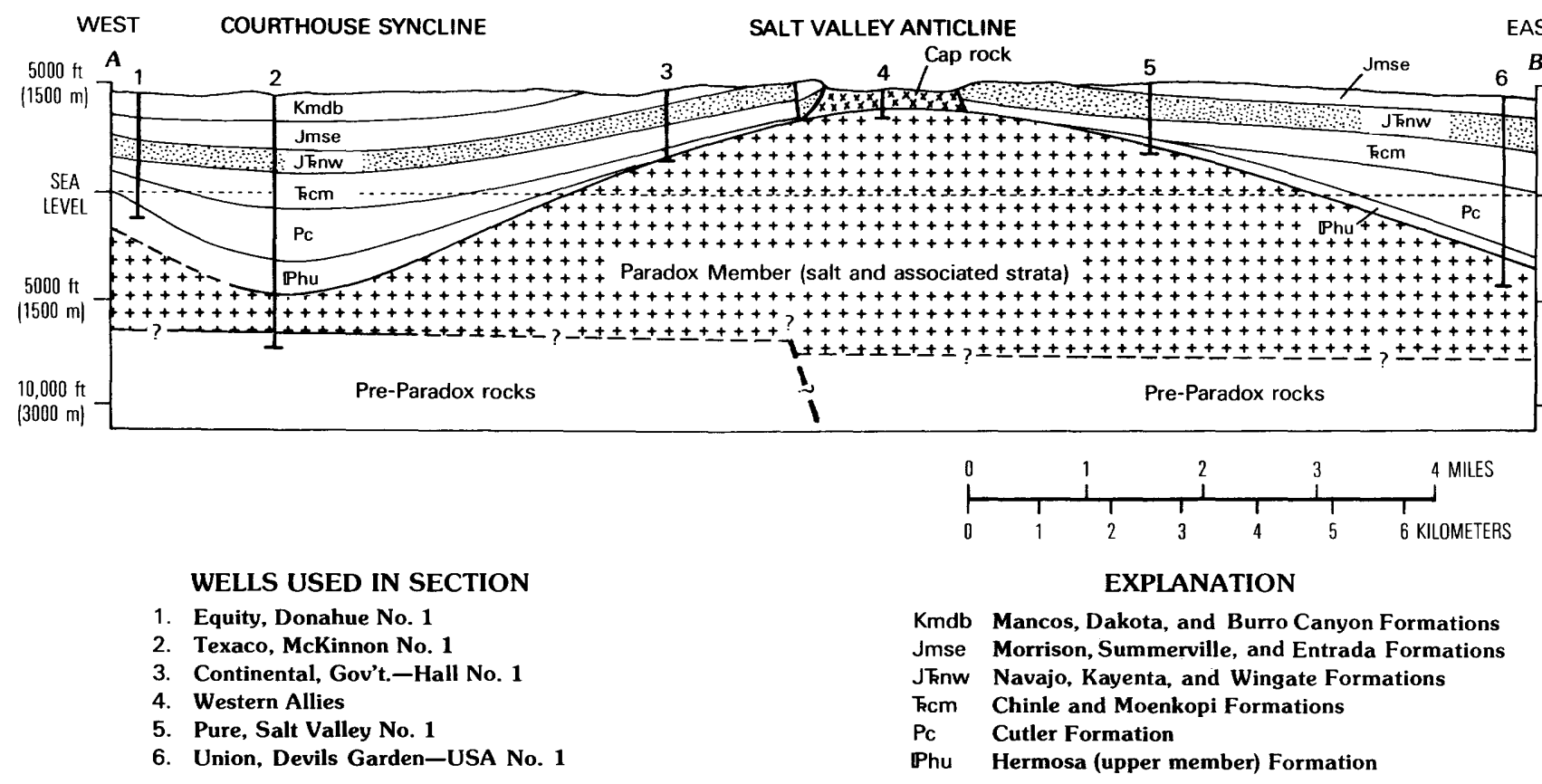

Figure 2.56. Cross section through Salt Valley anticline in Grand County, Utah, showing thickened Paradox salt and arching of overlying strata (modified from Hite and Lohman, 1973). Cap rock, containing chaotic masses of gypsum and other insoluble rock, forms along the crest of the anticline. Line of cross section $A-B$ is shown in figure 2.55 .

bounding the basin are the Nacimiento uplift on the east, the San Juan Mountains to the north, and the Zuni and Defiance uplifts on the south and west (fig. 2.57). Structural features within the basin and the adjacent uplifts were formed mainly during Late Cretaceous and early Tertiary (Laramide) time, and broad epeirogenic uplift of the region occurred still later in the Tertiary Period (Woodward and Callender, 1977).

Sedimentary rocks that fill the San Juan basin are continental and marine in origin, and range in age from Paleozoic through Cenozoic. Total thickness of these strata is as much as $4,000 \mathrm{~m}$. Jurassic rocks are typically $300-450 \mathrm{~m}$ thick in the basin, and they are overlain by as much as 2,000-2,500 m of Cretaceous and Tertiary strata in the northeast.

The Todilto Formation consists of a lower petroliferous limestone unit that is widespread throughout the San Juan basin and an upper anhydrite unit that is restricted to the eastern half of the basin (fig. 2.57). The limestone commonly ranges from 1 to $6 \mathrm{~m}$ in thickness, whereas the thickness of the anhydrite is $25-30 \mathrm{~m}$ in most areas; Tanner (1972) reported that locally it is as much as $40 \mathrm{~m}$ thick. In outcrops along the south and east side of the basin, the anhydrite has been hydrated to gypsum, which is being or has been quarried at Rosario, San Ysidro, Mesita, and other localities (Weber and Kottlowski, 1959).
Outcrops of the Todilto consist partly of laminated gypsum, but mostly of nodular gypsum. Anderson and Kirkland (1960) observed a laminated sequence of gypsum and limestone of marine origin. Gypsum is the dominant rock in the sequence in outcrop, and the dark laminae consist of microcrystalline calcite and minor amounts of bituminous matter and clastics. The overall purity of the unit is high; analyses showing that it contains 92-98 percent gypsum at various localities (Weber and Kottlowski, 1959). In some areas, nodular gypsum is a significant part of the sulfate unit. Stapor (1972) described gypsum outcrops that are in the form of mounds and that consist of white, nodular gypsum interbedded with gray, fetid, laminated limestone. The mounds, which are flat-topped and steep-sided masses of gypsum 10-30 m high, were also described by Anderson and Kirkland (1960) and Tanner (1972); the mounds appear to have resulted chiefly from ground-water dissolution of a blanket gypsum deposit.

Todilto gypsum also is present outside the San Juan basin. Small outcrops are present southeast of the basin, in parts of southeast Sandoval County, N. Mex., and in nearby areas (fig. 2.57). These occurrences are isolated and faulted, however, and it is unlikely that anhydrite underlies even a moderate-sized area. The equivalent Pony Express Member of the Wanakah 


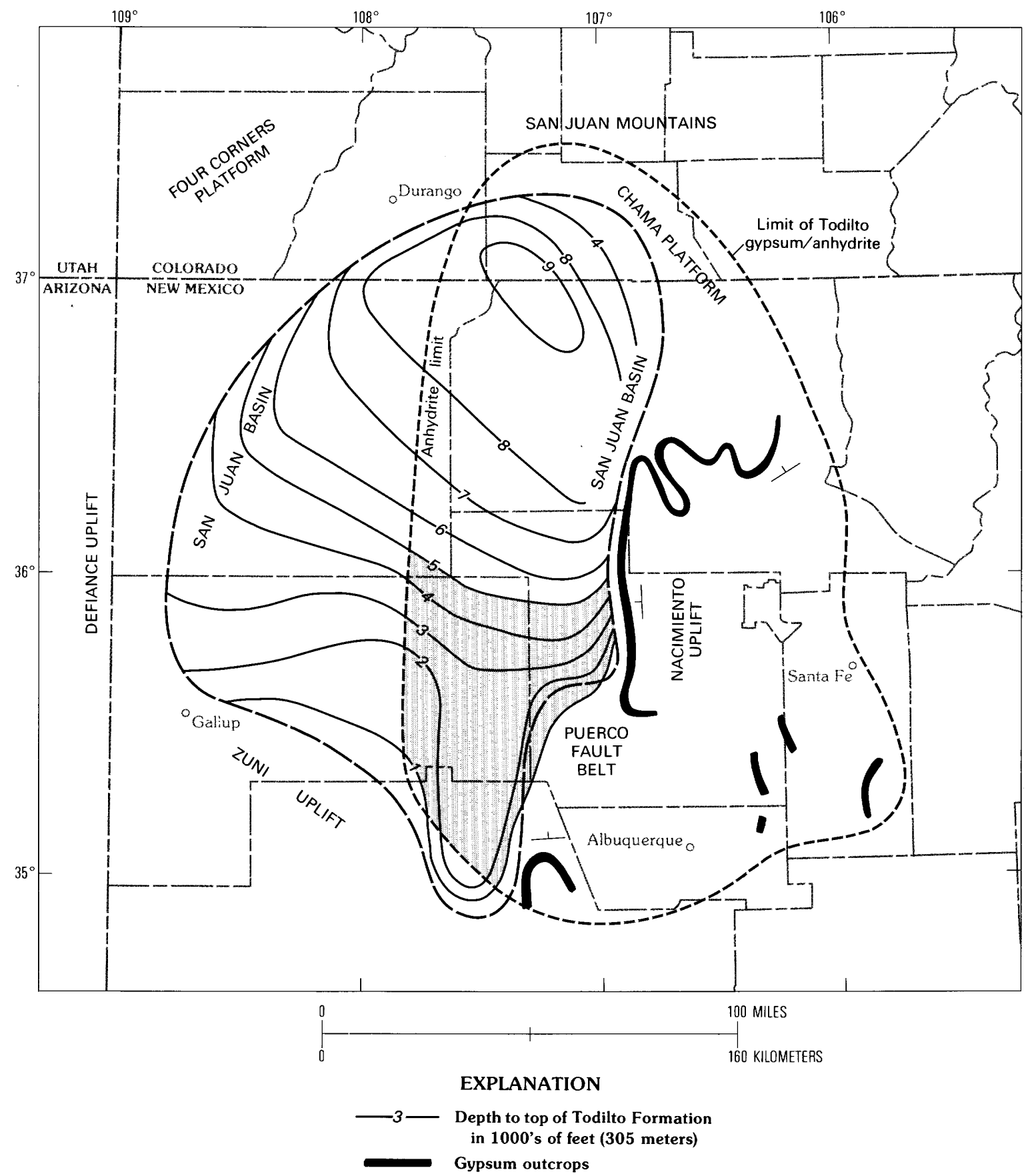

Figure 2.57. Map showing distribution and depth to top of Todilto Formation in the San Juan basin area of northwestern New Mexico and southwestern Colorado. Shaded area shows where thick anhydrite is $300-1,500 \mathrm{~m}$ beneath the surface. Western limit of anhydrite is generalized from maps of Withington (1962), Staper (1972), and Tanner (1972).

Formation crops out on the flanks of the San Juan Mountains and in other areas of southwest Colorado where undisturbed, thick anhydrite beds at moderate depth are unlikely.

Todilto anhydrite is restricted mainly to the eastern half of the San Juan basin. The anhydrite dips gently northward and ranges in depth from about $300 \mathrm{~m}$ in
Valencia County on the south to about $1,500 \mathrm{~m}$ in northern McKinley and Sandoval Counties (fig. 2.57). Throughout this area the Todilto is generally undeformed, except in the Puerco fault-belt area at the southeastern edge of the basin. In the northeastern part of the basin the top of the Todilto is $1,500 \mathrm{~m}$ to as much as $2,700 \mathrm{~m}$ below the surface. Still farther northeast, the 
Todilto rises sharply and is present over parts of the Chama platform at depths of about $300 \mathrm{~m}$. The Todilto anhydrite may be as much as $30 \mathrm{~m}$ thick and a little more than $300 \mathrm{~m}$ deep at various localities on the Chama platform.

\section{SUPAI SALT BASIN-SUPAI FORMATION}

A thick sequence of marine evaporites is present in the upper part (Lower Permian part) of the Supai Formation at moderate depths in east-central Arizona (fig. 2.1). The area is generally referred to as the Supai salt basin, but is also called the Holbrook basin in some reports. Rock salt is the dominant lithology in the upper member of the Supai, although anhydrite interbeds also occur in layers that range from 1 to $6 \mathrm{~m}$ in thickness. The evaporites of the Supai basin were described in detail by Peirce and Gerrard (1966) and Dean and Tung (1974), whereas Mytton (1973) and Johnson and Gonzales (1978) discussed aspects of the salt deposits as they relate to the storage of radioactive wastes.

The Supai salt basin underlies about $6,000 \mathrm{~km}^{2}$ in Navajo and Apache Counties, Ariz., and is on the southern edge of the Colorado Plateau (fig. 2.58).
Bounded by the Mogollon Rim on the south, by the Black Mesa basin on the northwest, and by the Defiance uplift on the northeast, the basin contains sedimentary rocks that dip to the north and northeast at an angle of $0.5^{\circ}-1^{\circ}$ and form a dip slope called the Mogollon slope (fig. 2.59).

The Supai Formation, the thickest rock unit in the area, consists of red sandstone, siltstone, and mudstone interbedded with halite, anhydrite, gypsum, and potash. The total thickness of the Supai Formation ranges from about $500 \mathrm{~m}$ near the Arizona-New Mexico State line to more than $800 \mathrm{~m}$ near Holbrook, Ariz. (Mytton, 1973). The Supai salt basin, a depositional center during Early Permian time, represents the area of maximum thickening of Permian strata in Arizona. A thick sequence of interbedded evaporites and clastics was deposited in shallow-marine waters that entered the basin from the south and that were cut off intermittently from the main body of seawater.

The Supai Formation has been subdivided in the subsurface in this area into a lower and an upper member, separated by the Fort Apache Member (Peirce and Gerrard, 1966). Although some evaporites occur in the lower member and in the Fort Apache Member, the thickest evaporites are in the upper member of the
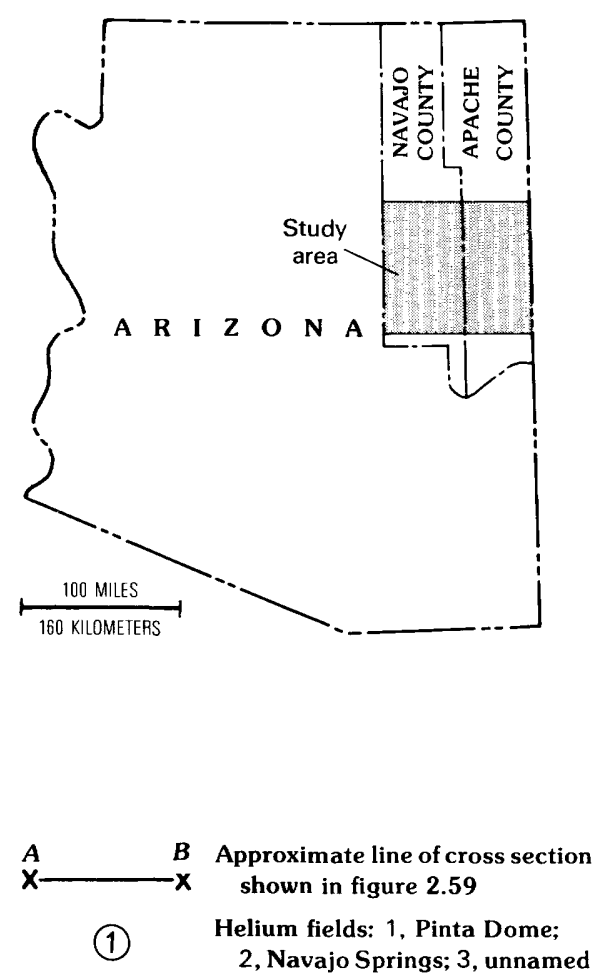

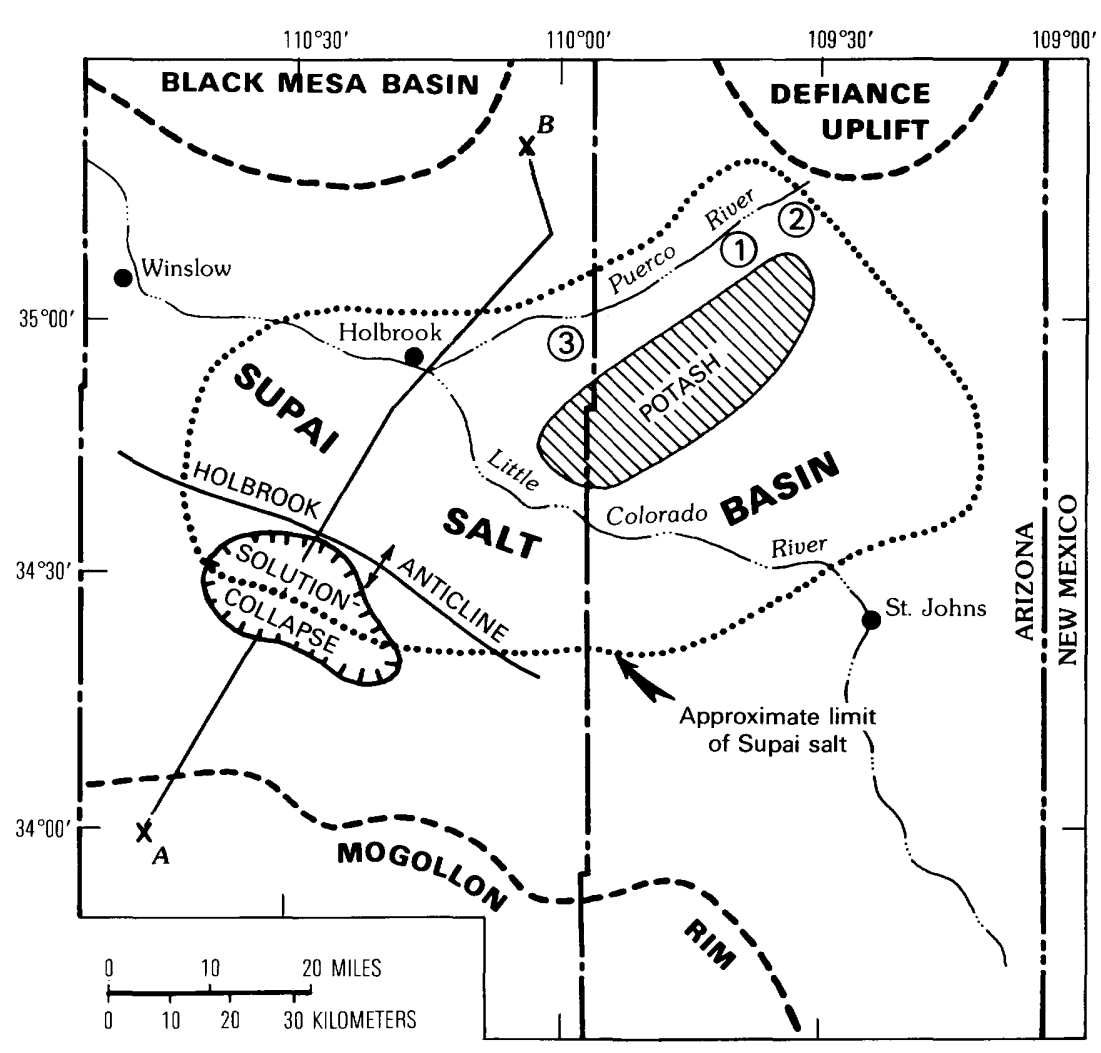

Figure 2.58. Index map of Supai salt basin and surrounding area showing structural features and mineral deposits of east-central Arizona (modified from Mytton, 1973; Johnson and Gonzales, 1978). 


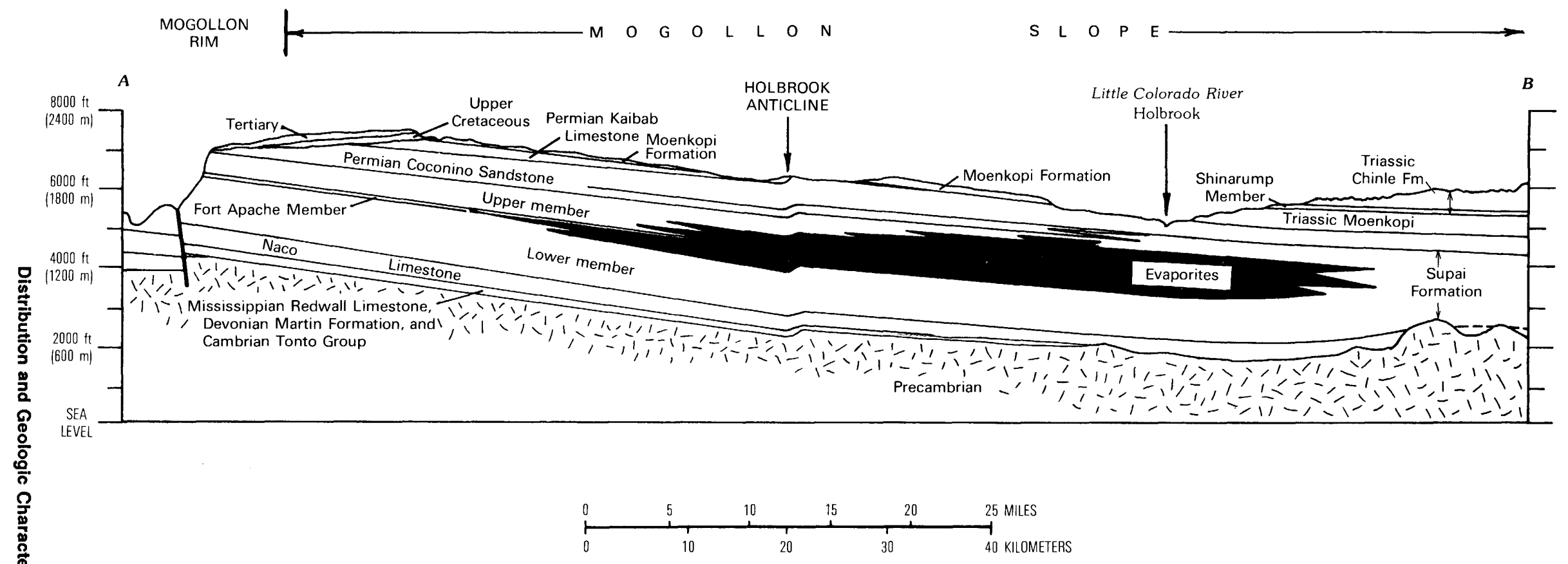

Figure 2.59. Generalized geologic cross section through the Supai salt basin showing position of upper member of the Supai Formation (modified from Brown and Lauth, 1958; Johnson and Gonzales, 1978). Line of cross section $A-B$ is shown in figure 2.58. 
formation, which lies between the Fort Apache Member and the overlying Permian Coconino Sandstone (fig. 2.60). Thickness of the upper Supai ranges from about $300 \mathrm{~m}$ around the perimeter of the basin to about $400 \mathrm{~m}$ near the center (fig. 2.61). The depth below ground level to the top of the evaporites ranges from about 180 to $750 \mathrm{~m}$; the greatest depths are found in the northeast part of the basin.

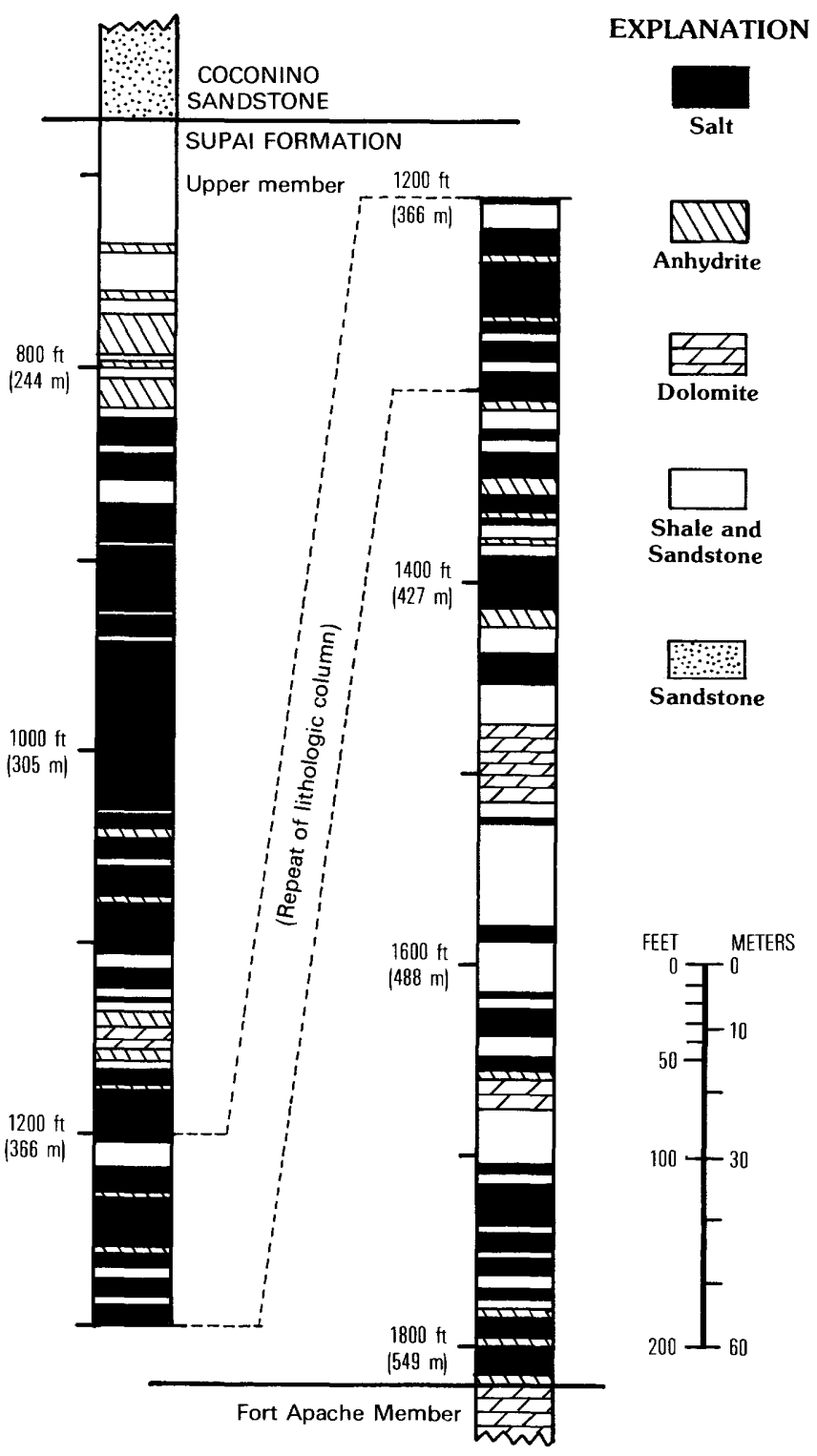

Figure 2.60. Composite lithologic column of upper member of the Supai Formation in Supai salt basin. Lithology below $250 \mathrm{~m}$ (and all depth information) based upon core description of Scott Brothers Stratigraphic Test No. 2 well, sec. 24, T. 15 N., R. $22 \mathrm{E}$; lithology above $250 \mathrm{~m}$ based upon interpretation of mechanical logs of Webb Resources, Inc., Mexico, and Arizona Land Co. No. 6-1 well, sec. 6, T. 14 N., R. 22 E. Location of wells shown on figure 2.61 .
Halite is the chief evaporite mineral in the upper Supai, although anhydrite is interbedded with the halite (figs. 2.60 and 2.62) and potash salts are distributed widely at one stratigraphic position. The thickness of individual halite beds ranges from 2 to $10 \mathrm{~m}$ at most places, and the layers of anhydrite are typically 1-6 m thick based on examination of mechanical logs and core descriptions; the thicker anhydrite beds are mainly near the top and the bottom of the evaporite sequence. Individual evaporite beds are laterally persistent in the basin; this observation is well established by our regional studies and by the detailed correlation (Dean and Tung, 1974) of strata in two cores of the Supai evaporites drilled $8 \mathrm{~km}$ apart (fig. 2.62). Red-brown shale and siltstone beds and several beds of dolomite are interbedded with the evaporites.

\section{BASIN AND RANGE PROVINCE OF ARIZONA AND SOUTHERN NEVADA}

\section{Structure and Geologic Framework}

The southern part of the Basin and Range Province in Arizona and southern Nevada contains a number of alluvium-filled valleys underlain by more than $2,000 \mathrm{~m}$ of Cenozoic sediments. An episode of late Miocene block faulting, dated by Eberly and Stanley (1978) at 12-13 m.y. ago, created a horst-and-graben region in which the down-dropped blocks received thick accumulations of continental clastic sediments interbedded with some volcanic rocks and, in some grabens, thick evaporite deposits (Peirce, 1976; Eberly and Stanley, 1978).

Evaporite deposits are reported in 10 of the troughlike basins. Thick evaporites are present in the Picacho, Chandler, Phoenix, Red Lake, and Virgin Valley basins, whereas thinner evaporite units are reported in the Red Rock, Tucson, Verde Valley, Tonto, and Safford Valley basins (fig. 2.63). Although halite or rock salt is reported from each of the basins, anhydrite has been drilled only in the Picacho, Chandler, Phoenix, Red Rock, Tucson, and Virgin Valley basins. The greatest thickness of anhydrite was found in the Picacho basin, where individual anhydrite beds as much as $37 \mathrm{~m}$ thick are present in an 1,800-m-thick sequence that consists mainly of anhydrite.

Evaporites in the region were deposited during late Miocene (or later) time, chiefly in the central part of each closed basin, but thick sequences of Miocene and postMiocene gravel, sand, and clay that envelope the evaporites were deposited in fluvial and lacustrine environments. The type of evaporite in each basin depended upon the chemical constituents carried into the basin by the then-existing drainage system. Volcanic rocks are interbedded locally with the nonmarine clastic sediments. 


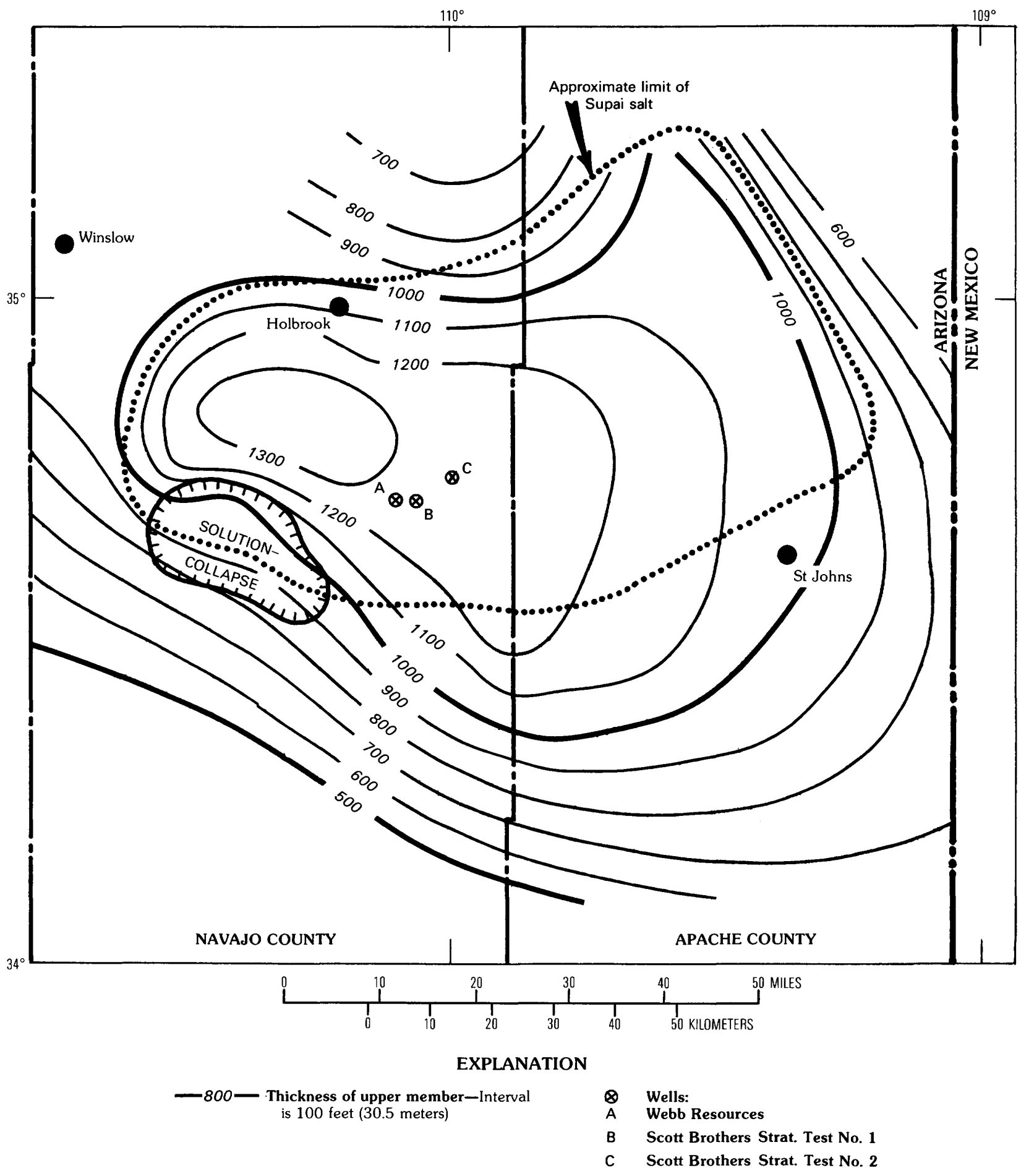

Figure 2.61. Thickness, in feet, of upper member of the Supai Formation, and location of three wells shown in figures 2.60 and 2.62 (modified from Peirce and Gerrard, 1966; Johnson and Gonzales, 1978).

A nonmarine origin has been suggested for evaporites in the basins. On the basis of a bromine content in halite that is well below the threshold value indicative of marine halite, Eaton and others (1972) and Eberly and Stanley (1978) concluded that the Miocene Luke Salt Member of the Hickey Formation in the Phoenix basin probably was deposited in a saline lake.

\section{Picacho Basin-Miocene Evaporites}

A thick sequence of unnamed evaporites of late Tertiary (Miocene) age is present in the block-faulted Picacho basin of south-central Arizona (fig. 2.63). These strata consitute one of the thickest $(1,800 \mathrm{~m}$ thick), if not 


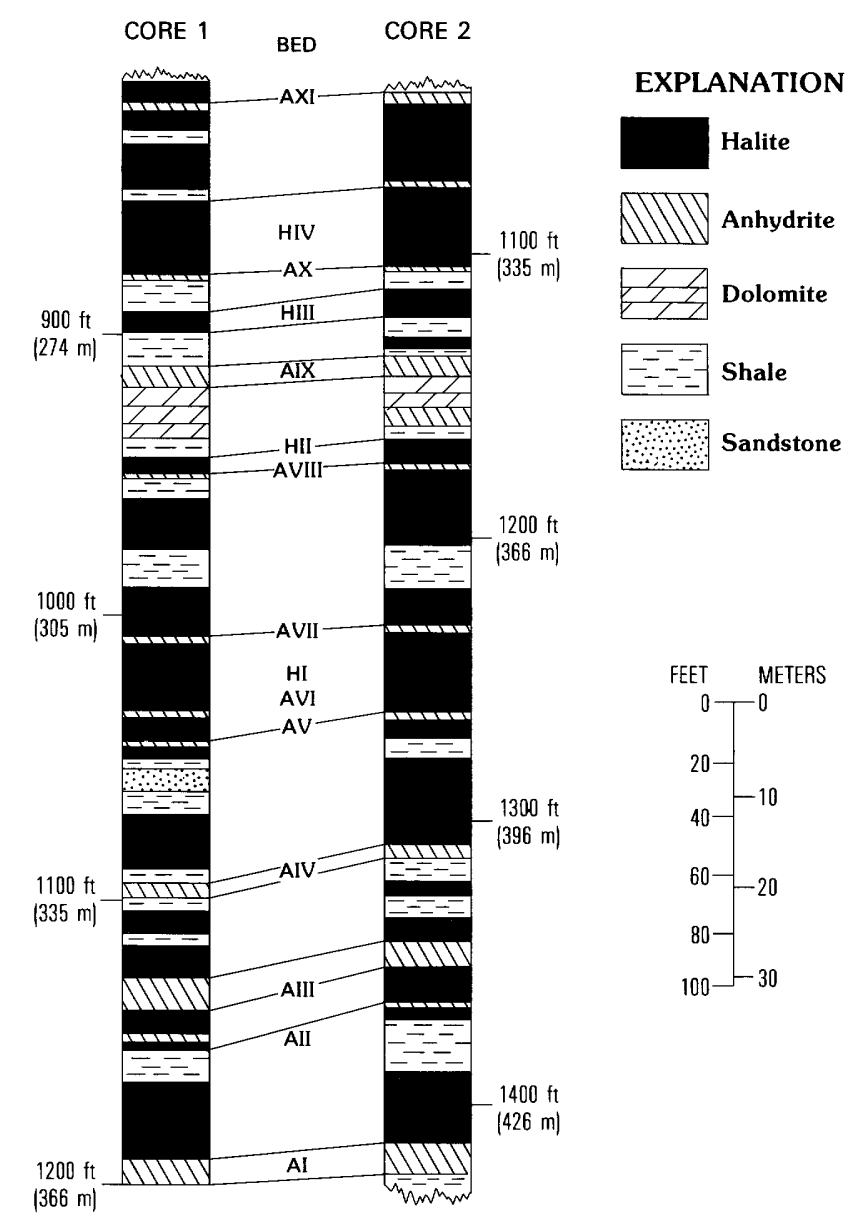

Figure 2.62. Detailed lithologic columns of two cores $8 \mathrm{~km}$ apart showing correlation of evaporite units in part of upper member of the Supai Formation (modified from Dean and Tung, 1974). Core 1 is from Scott Brothers Stratigraphic Test No. 1 well, sec. 5, T. 14 N., R. 22 E; Core 2 is from Scott Brothers Stratigraphic Test No. 2 well, sec. 24, T. 15 N., R. 22 E. Locations of wells are shown in figure 2.61 .

the thickest, sequences consisting mostly of anhydrite reported from any part of the world. Individual anhydrite beds in the top $600 \mathrm{~m}$ of the sequence are typically 2-10 m thick, whereas those in the lower part are commonly $10-37 \mathrm{~m}$ thick at depths ranging from about 1,300 to $2,500 \mathrm{~m}$. The occurrence of this anhydrite was reported by Peirce $(1973,1974$, and 1976); a subsequent study by Eberly and Stanley (1978) summarized the geologic history and evaporites both here and in several other basins in Arizona.

The Picacho basin, a north-northeast-trending structure about $50 \mathrm{~km}$ long and $15 \mathrm{~km}$ wide, is about $90 \mathrm{~km}$ southeast of Phoenix in Pinal County, about midway between Phoenix and Tucson. The basin formed during late Miocene block faulting as one of a series of

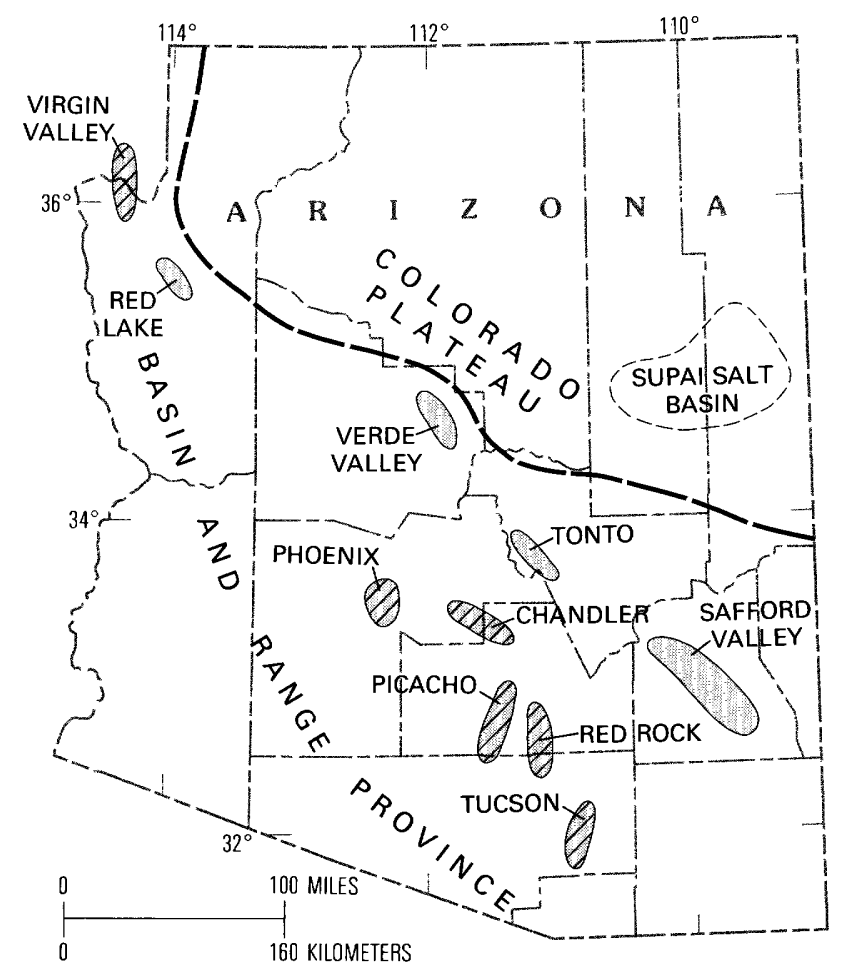

Figure 2.63. Basins of the Basin and Range Province in Arizona and southern Nevada that contain major nonmarine evaporite deposits. Halite is present in all 10 basins (shaded), whereas anhydrite is reported from only 6 basins (line pattern).

basin-and-range structures consisting of grabens or halfgrabens separated by mountain-forming horsts (Peirce, 1976; Eberly and Stanley, 1978).

Although most of the grabens or valleys in the region are filled with several thousand meters of conglomerate, sandstone, siltstone, claystone, and volcanic rock, the Picacho basin was also the site of a major episode of evaporite deposition during late Miocene time (fig. 2.64). Thick beds of anhydrite and some layers of salt were deposited in the central part of the Picacho basin, whereas the fringes of the basin received fluvial and lacustrine clastics. The clastics periodically were spread across the evaporite pan and became interbedded with the anhydrite layers. Overlying the evaporites is a sequence of red-brown claystone, sandstone, and conglomerate, containing a few interbeds of anhydrite, gypsum, and salt (Eberly and Stanley, 1978).

Few data are available on the structure within the basin, but complex features are not reported and Peirce (1974) pointed out that the anhydrite is not noticeably disturbed. 


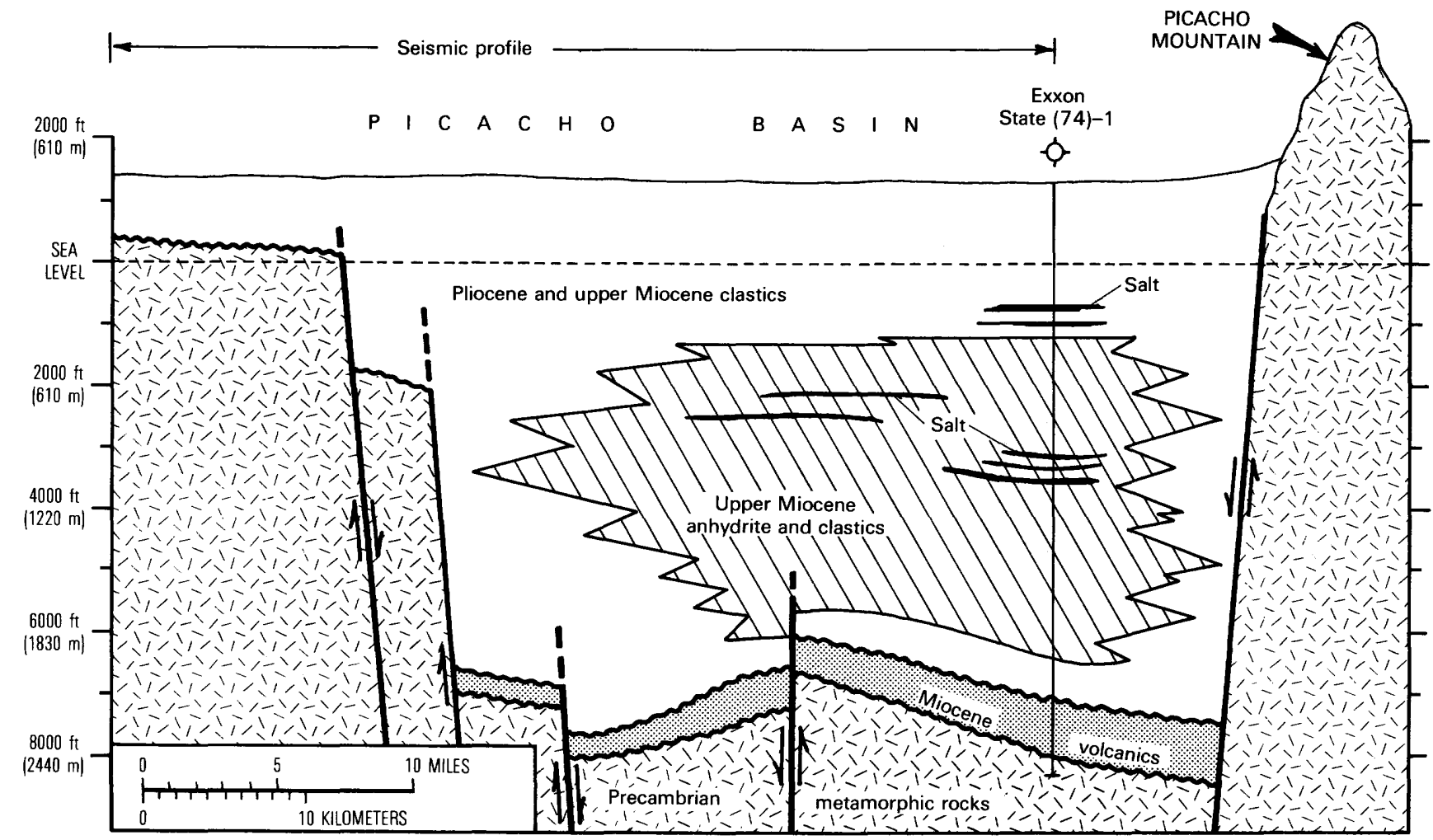

Figure 2.64. Schematic cross section through Picacho basin of south-central Arizona showing thick nonmarine sequence of interbedded anhydrite and clastics (modified from Eberly and Stanley, 1978).

The evaporite sequence is best understood from data released from a deep test hole, the Exxon State (74)-1, which penetrated $1,800 \mathrm{~m}$ of anhydrite-bearing strata in sec. 2, T. 8 S., R. 8 E. (figs. 2.64 and 2.65). The main sequence of anhydrite was penetrated between 718 and $2,518 \mathrm{~m}$, although the strata from $558-587 \mathrm{~m}$ also have been described as anhydrite on a commercial sample $\log$ (American Stratigraphic Company, AMSTRAT $\log$ D-3978).

Anhydrite in the Exxon well is described as white in the upper part of the sequence and white, gray, and some mottled light brown below $1,353 \mathrm{~m}$. The anhydrite is interbedded with brown and greenish-gray claystone and siltstone layers, along with a few thin tuff beds that are green and bentonitic (AMSTRAT log D-3978; Eberly and Stanley, 1978). Rock salt occurs in two beds above the main anhydrite and in four beds, $2-10 \mathrm{~m}$ thick, in the depth range of 1,438-1,514 m (fig. 2.65). At depths from 2,320 to $2,518 \mathrm{~m}$, the anhydrite is white and light brown and contains limestone nodules, oolites, indistinct fossil fragments, and white and cream chert.

Anhydrite makes up about 65 percent of the total thickness of strata within the 1,800-m-thick anhydrite sequence in the Exxon well. The percentage of anhydrite in the sequence generally increases with increasing depth (fig. 2.66). Also, both the number of anhydrite beds and the total number of beds in each $30 \mathrm{~m}$ of depth decrease with increasing depth (figs. 2.67 and 2.68). Because the amount of anhydrite increases with depth, more favorable thicknesses of anhydrite are likely at greater depths, particularly between 1,400 and $1,600 \mathrm{~m}$.

Thickness of individual anhydrite beds in the Exxon well ranges from 2-37 m, and many of the beds are more than $10 \mathrm{~m}$ thick (fig. 2.65). Beds in the top $592 \mathrm{~m}$ of the sequence (from 718 to $1,310 \mathrm{~m}$ ) are typically $2-10 \mathrm{~m}$ thick, and they are interbedded with claystone and siltstone beds $2-15 \mathrm{~m}$ thick. In the lower part of the sequence, particularly at depths ranging from 1,310 to $2,289 \mathrm{~m}$, the anhydrite beds are commonly $10-37 \mathrm{~m}$ thick and are interbedded with fine clastic units $1-7 \mathrm{~m}$ thick. The maximum thickness for a single anhydrite bed is $37 \mathrm{~m}$ at a depth range of $1,594-1,631 \mathrm{~m}$. Several other intervals of anhydrite beds are nearly $50 \mathrm{~m}$ thick, but they contain one or more claystone layers about $1 \mathrm{~m}$ thick.

Fine- to coarse-grained clastics of probable late Miocene, Pliocene, Pleistocene, and Holocene age overlie the evaporites in the Picacho basin. The top $110 \mathrm{~m}$ in the Exxon well (Eberly and Stanley, 1978) 

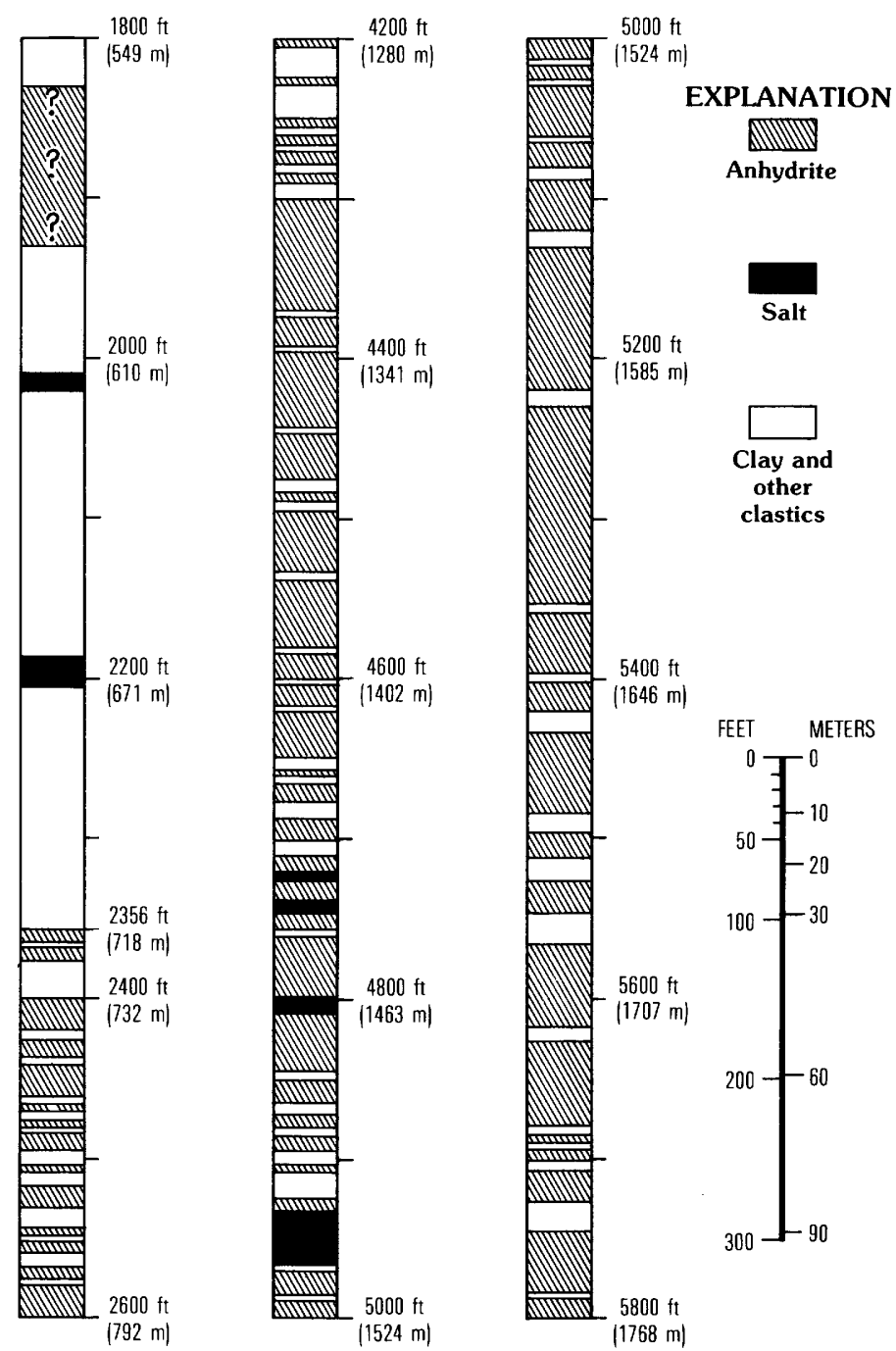

Figure 2.65. Lithologic column showing selected parts of evaporite sequence penetrated by Exxon State (74)-1 well in sec. 2, T. 8 S., R. 8 E., in Picacho basin, Arizona. Lithology interpreted from mechanical logs, from American Stratigraphic Co. AMSTRAT log D-3978, and from descriptions of Eberly and Stanley (1978).

consists of coarse unconsolidated gravels, and the interval from 110 to $198 \mathrm{~m}$ is unconsolidated sand with clay beds and scattered gravel lenses. From 198 to $718 \mathrm{~m}$ (top of anhydrite sequence), the strata consist mainly of beds of red-brown claystone that are silty and sandy and that contain nodules and stringers of gypsum and anhydrite; the reported occurrence of anhydrite at 558-587 m should be examined further.

\section{Chandler Basin-Miocene Evaporites}

The Chandler basin, about $40 \mathrm{~km}$ east of Phoenix in Maricopa and Pinal Counties (fig. 2.63), contains a thick sequence of evaporites in which anhydrite is the dominant rock type. Anhydrite beds range from 700 to about $1,200 \mathrm{~m}$ beneath the surface, and individual beds are reported to be $\mathbf{2 - 1 0 6} \mathrm{m}$ thick. In many ways this deposit is similar to that of the Picacho basin, located about $40 \mathrm{~km}$ to the south. The evaporites in the Chandler basin were discovered in 1973 during the drilling of two deep boreholes, and were described briefly by Eberly and Stanley (1978).

The Chandler basin is a large alluvium-filled valley about $50 \mathrm{~km}$ long and $25 \mathrm{~km}$ wide. The basin has had the same basic geologic history as have others in the arealate Miocene block faulting, followed by filling of the basin with gravel, sand, clay, and volcanics; and evaporite 


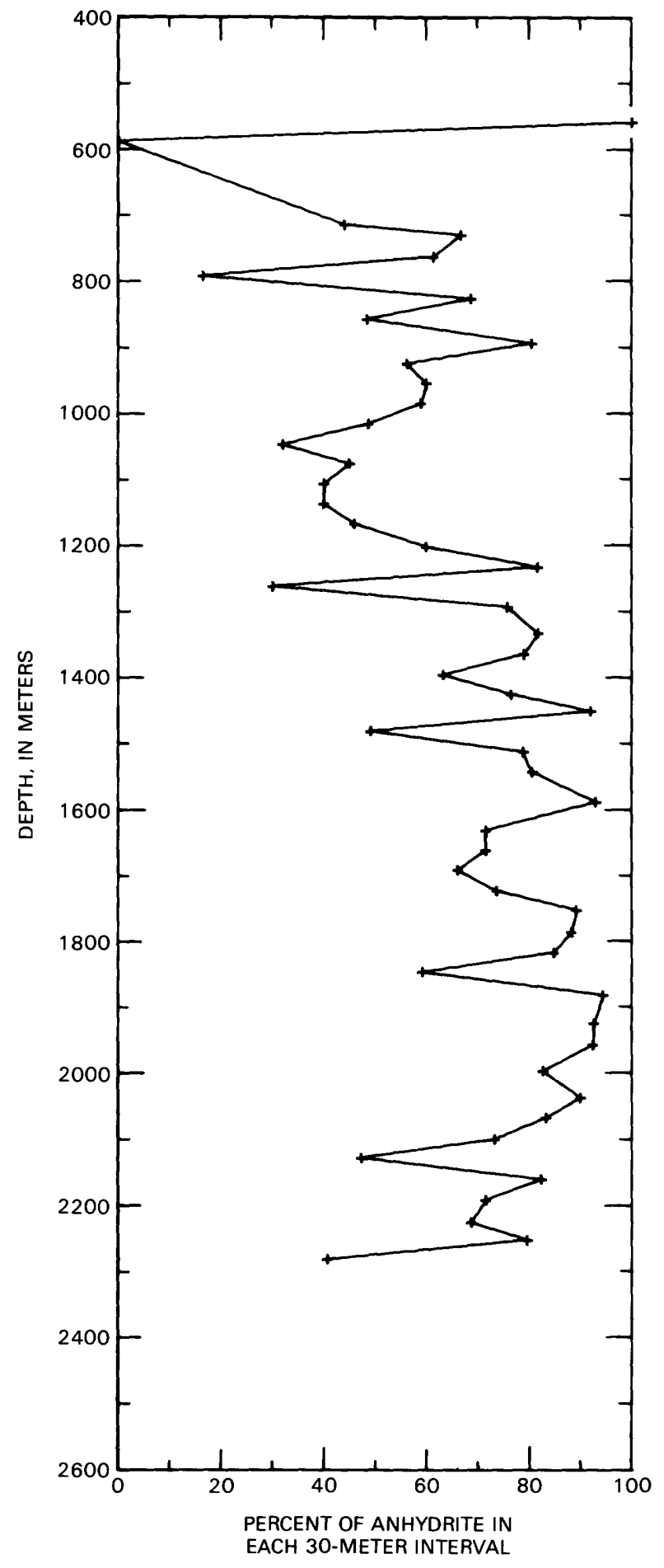

Figure 2.66. Graph showing percent thickness of anhydrite beds per 30-m interval of depth in the Exxon State (74)-1 well, drilled in the Picacho basin of Arizona (based on American Stratigraphic Co., AMSTRAT log D-3978).

deposition in the central part of the basin during much of late Miocene time.

Data on evaporites in the Chandler basin are limited to those available from the two deep boreholes

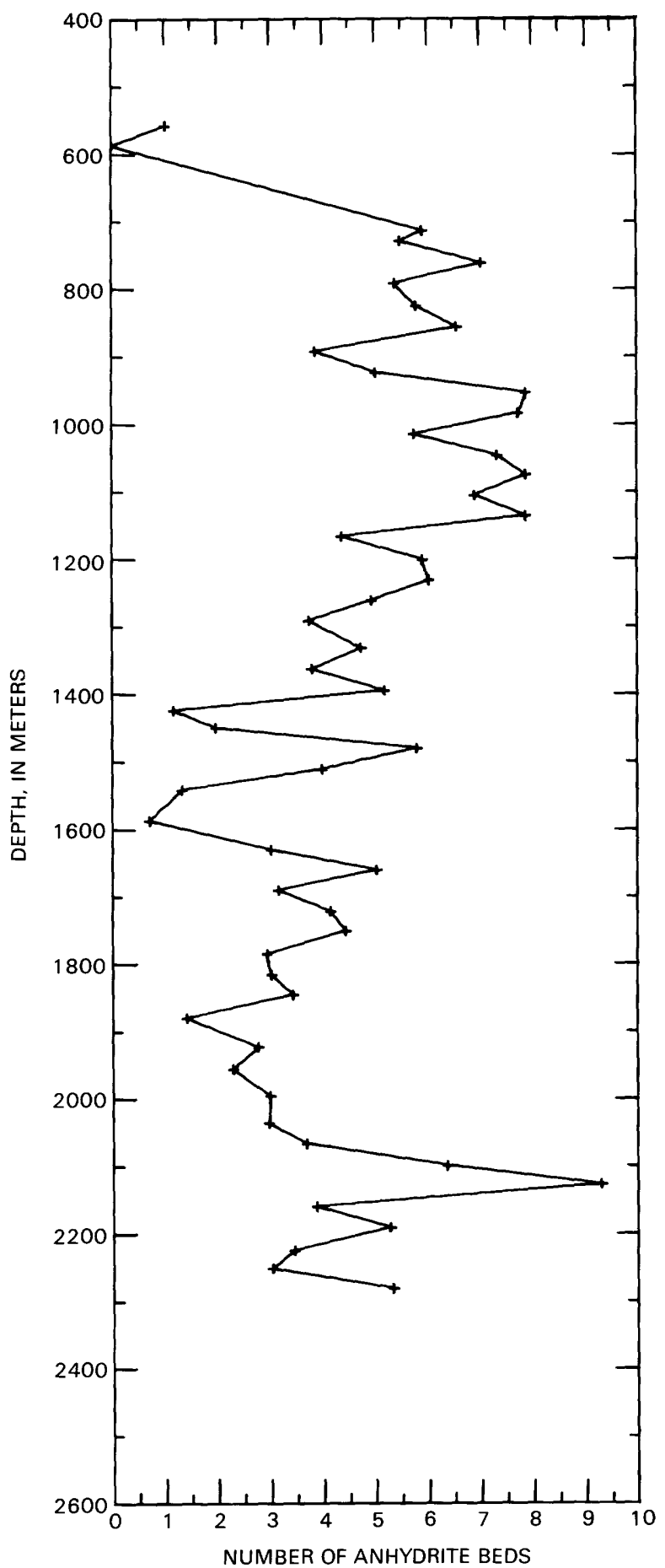

Figure 2.67. Graph showing number of anhydrite beds per 30-m interval of depth in the Exxon State (74)-1 well, drilled in the Picacho basin of Arizona (based on American Stratigraphic Co., AMSTRAT log D-3978).

drilled in 1973. Geothermal Kinetics Systems Corporation drilled the Power Ranches No. 1 in NE $1 / 4 \mathrm{SE}^{1 / 1} 4 \mathrm{sec} .1$, T. 2 S., R. 6 E., and the Power Ranches No. 2 in $\mathrm{SE}^{1 / 4} \mathrm{NE}^{1 / 4}$ of the same section in eastern Maricopa 


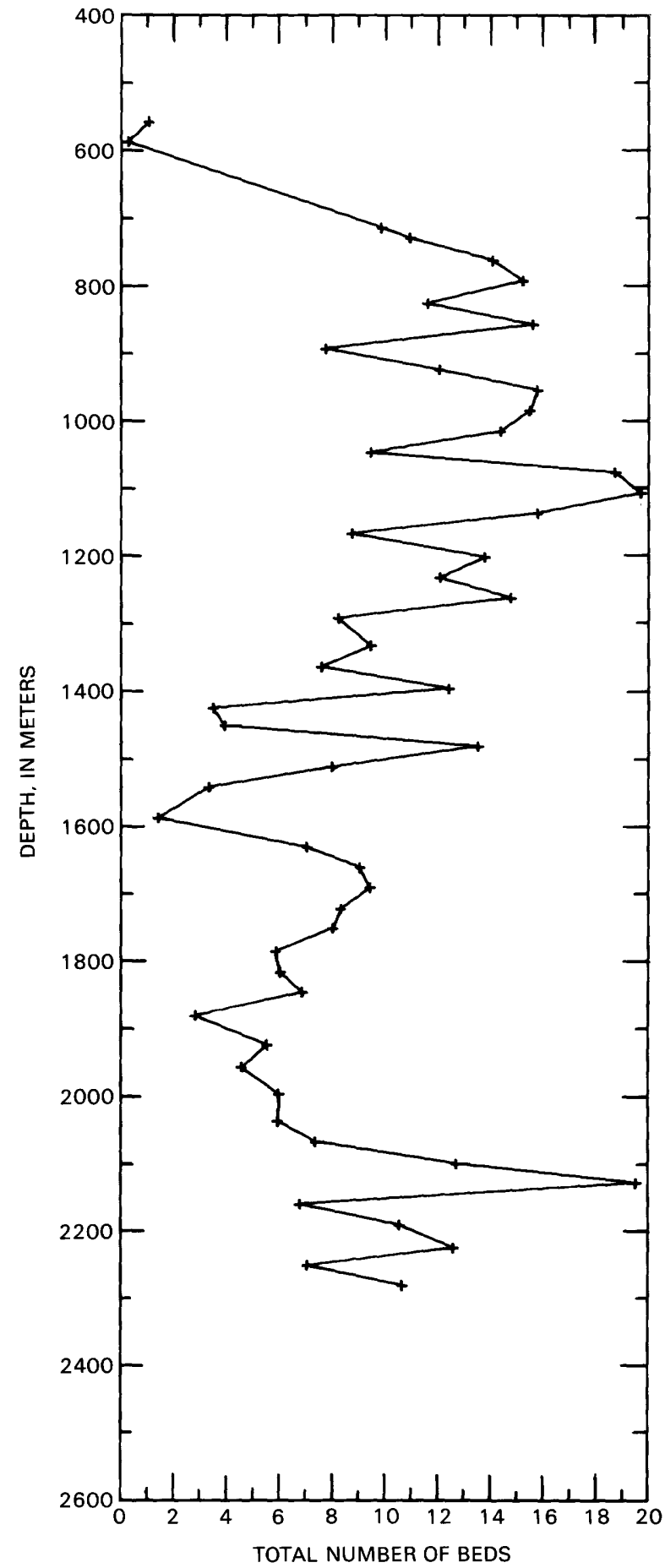

Figure 2.68. Graph showing total number of beds (anhydrite and other rock types) per 30-m interval of depth in the Exxon State (74)-1 well, drilled in the Picacho basin of Arizona (based on American Stratigraphic Co., AMSTRAT $\log$ D-3978).

County, Ariz. The No. 1 and No. 2 wells have nearly the same surface elevation, and they penetrated the top of the anhydrite section at depths of 701 and $700 \mathrm{~m}$, respectively. Total thickness of the anhydrite sequence is
$460 \mathrm{~m}$ in well No. 1 and $505 \mathrm{~m}$ in well No. 2, as shown on commercial sample logs (AMSTRAT logs D-4113 and D-4335, respectively).

Anhydrite, which is described as being white and gray, contains thin stringers and partings of brown claystone and siltstone in the two wells; anhydrite beds are intercalated with beds of claystone, siltstone, and shale. Rock salt is not reported from either well.

Based on the AMSTRAT sample logs, anhydrite makes up about 38 percent of the evaporite sequence in well No. 1 and about 60 percent in well No. 2. Thickness of individual anhydrite beds in well No. 1 typically ranges from 2 to $6 \mathrm{~m}$, but one bed $14 \mathrm{~m}$ thick occurs at a depth of $936 \mathrm{~m}$ and another bed $21 \mathrm{~m}$ thick occurs at a depth of $1,092 \mathrm{~m}$. Many of the anhydrite beds in well No. 2 are 2-10 $\mathrm{m}$ thick, but in the upper part of the sequence the sample $\log$ indicates the following thick anhydrite units that contain stringers of siltstone and claystone: one bed $30 \mathrm{~m}$ thick at a depth of $700 \mathrm{~m}$, a second bed $106 \mathrm{~m}$ thick at a depth of $774 \mathrm{~m}$, and a third bed $20 \mathrm{~m}$ thick at a depth of $907 \mathrm{~m}$.

The percentage of anhydrite and the maximum thickness of anhydrite beds reported in these two sample logs are not consistent with each other, yet from other data in the area the evaporite sequence should be expected to correlate fairly well over the short $400-\mathrm{m}$ distance that separates the two wells. Therefore, all data from these two wells must be more fully evaluated to establish which log most accurately represents the evaporite section at the site or if the evaporites change markedly over such a short distance.

Upper Miocene and younger clastic sediments overlie the anhydrite and fill the Chandler basin. Both wells penetrate gravel and sand from the surface down to about $335 \mathrm{~m}$; from $335 \mathrm{~m}$ to the top of anhydrite, they penetrate tan to brown claystone that is calcareous and bentonitic.

\section{Phoenix Basin-Luke Salt Member}

The Phoenix basin (also referred to as the Luke basin in some reports) contains a thick sequence of upper Miocene rock salt (halite) and shale interbeds at shallow depth in central Arizona (fig. 2.63). The domelike mass of salt is overlain by a thin sequence of anhydrite layers $2-10 \mathrm{~m}$ thick at a depth of about $300 \mathrm{~m}$. Beyond the flanks of the salt mass, anhydrite beds of similar thickness occur nearly $1,500 \mathrm{~m}$ below the surface. The salt body is near Luke Air Force Base, about $25 \mathrm{~km}$ west of Phoenix in Maricopa County, Ariz., and is believed to underlie slightly more than $100 \mathrm{~km}^{2}$ and to extend from less than $300 \mathrm{~m}$ below the surface to a total depth of probably 
more than 3,500 m. Data presented here on the evaporites in the Luke Salt Member of the Hickey Formation are summarized from work by Eaton and others (1972), Mytton (1973), Peirce (1974, 1976), and Eberly and Stanley (1978). Johnson and Gonzales (1978) discussed the potential for disposal of radioactive wastes in salt beds in the Luke evaporites.

An exploratory test hole drilled just east of Luke Air Force Base penetrated about $1,085 \mathrm{~m}$ of halite without reaching the base of the salt. The top of the salt is about $265 \mathrm{~m}$ deep in this borehole. A generalized lithologic log of this test hole, based on an interpretation of gamma ray-neutron logs by R. J. Hite of the U.S. Geological Survey, was presented by Mytton (1973), as follows: (1) top $245 \mathrm{~m}$ not described, (2) $20 \mathrm{~m}$ of anhydrite, (3) $150 \mathrm{~m}$ of halite that contains scattered shale interbeds $0.6-2.4 \mathrm{~m}$ thick, (4) $180 \mathrm{~m}$ of argillaceous halite, (5) $150 \mathrm{~m}$ of halite alternating with argillaceous halite, and (6) $400 \mathrm{~m}$ of halite that contains scattered shale interbeds $0.3-2 \mathrm{~m}$ thick. Several other boreholes have been drilled into the top of the salt, but only a few meters of core have been taken.

Contact relationships between the salt and surrounding clastics are not yet clear, and so whether the salt flowed and caused diapirism is not known. The collapse of casing in several water wells and the presence of several open fissures in alluvium above the salt suggest that the salt may be rising and doming the overlying sediments (Eaton and others, 1972).

Mechanical logs of several test holes drilled through the anhydrite near the crest of the salt mass suggest that the anhydrite occurs in beds $2-10 \mathrm{~m}$ thick and that it is interbedded chiefly with fine-grained clastics. Total thickness of the anhydrite-bearing unit in the several tests drilled in sec. 2 , T. 2 N., R. 1 W., is $20-35 \mathrm{~m}$, and the depth to the top of the anhydrite ranges from 300 to $350 \mathrm{~m}$. Whether the anhydrite is a cap rock consisting of the insoluble residue from an upward-moving and partly dissolved salt diapir or whether it consists of sedimentary layers of anhydrite is not clear. We prefer the latter interpretation because (1) in some places $10 \mathrm{~m}$ of non-anhydrite rock occurs between the anhydrite and the top of the salt, (2) anhydrite apparently is interbedded with other rock types, (3) bedded anhydrite is known in at least one well drilled in the Phoenix basin away from the thick salt mass, and (4) bedded anhydrite is known to be associated with salt in other basins of the region.

In another test hole drilled 3-4 km farther west (Norris Oil Company No. 4 Tribal McBride, sec. 4, T. 2 N., R. 1 W.), anhydrite beds $2-4 \mathrm{~m}$ thick are present in a sequence of strata nearly $20 \mathrm{~m}$ thick at a depth of
$1,465 \mathrm{~m}$. Although the well was drilled to a total depth of 2,040 m, it did not penetrate the Luke Salt Member.

\section{Red Rock Basin-Miocene Evaporites}

Anhydrite is reported in the Red Rock basin in south-central Arizona in Pinal and Pima Counties (fig. 2.63). The basin is just east of the Picacho basin. Few data are available on this unnamed anhydrite unit, although a regional cross section by Eberly and Stanley (1978) showed the presence of about $150 \mathrm{~m}$ of anhydritebearing strata of Miocene age at a depth of $900 \mathrm{~m}$ beneath the surface. These evaporites apparently have been penetrated only in the Elroy Development No. 1 State (sec. 6, T. 12 S., R. 11 E.) well drilled in 1949.

Additional data are needed to assess the general thickness, depth, and character of this evaporite unit. Because of its similarity and proximity to the Picacho basin this could be an important anhydrite unit.

\section{Tucson Basin-Miocene Evaporites}

The Tucson basin in Pima County in southeastern Arizona (fig. 2.63) contains an unnamed sequence of upper Miocene evaporites. Data on this evaporite unit are sparse, but Eberly and Stanley (1978) described abundant gypsum crystals at a depth between 564 and $686 \mathrm{~m}$ and an anhydrite bed at a depth from 2,1642,167 $\mathrm{m}$ in the 3,837-m-deep Exxon State (32)-1 test hole drilled in sec. 5, T. 16 S., R. 15 E. Other test holes in the Tucson basin are rather shallow, generally $300-1,000 \mathrm{~m}$ deep, and are not reported to have penetrated thick evaporites.

Because the Exxon borehole was drilled on the eastern edge of the basin in the fan deposits, it did not adequately test whether a thick sequence of anhydrite exists at or near the depocenter. Eberly and Stanley (1978) postulated that the central part of the basin could contain thick anhydrite beds, perhaps similar in thickness to those of the Picacho basin, but this theory can be ascertained only by additional studies.

\section{Virgin Valley Basin-Muddy Creek Formation}

A thick sequence of evaporites crops out and is at shallow depths in the Virgin Valley basin in Clark County, southeastern Nevada, and its southward extension into the Detrital Valley of Mohave County, northwestern Arizona (fig. 2.63). Several hundred 
meters of halite and glauberite are the principal evaporite rocks in the unit, although thin gypsum beds crop out in much of the area and anhydrite beds are reported in the subsurface. Rock salt was exposed at the surface in parts of the Virgin Valley before the formation of Lake Mead inundated some of the area. Salt could exist at the surface because annual precipitation is only $12-25 \mathrm{~cm}$. The general geology of the area and brief statements about the gypsum outcrops were presented by Longwell (1928, 1936), Mannion (1963), and Longwell and others (1965); the general suitability of the salts for possible storage of radioactive waste was summarized by Netherland, Sewell and Associates (1977) and Johnson and Gonzales (1978).

Evaporites in the Virgin Valley-Detrital Valley area occur in the Muddy Creek Formation of late Tertiary (Miocene) age. Longwell and others (1965) stated that gypsum is abundant in outcrops of the Muddy Creek Formation, and that some of the beds are thick and extensive. Several boreholes drilled by Stauffer Chemical Company penetrated the evaporite section in Nevada and found anhydrite as a minor part of the total red bed-evaporite sequence (Mannion, 1963). According to detailed descriptions of these cores (Netherland, Sewell and Associates, 1977), most anhydrite occurs in bands and laminations that are interbedded with glauberite and shale at depths ranging from $200 \mathrm{~m}$ to more than $800 \mathrm{~m}$. From these descriptions, it appears that individual anhydrite beds in the area may not be much more than several meters thick.

Salt and adjacent rocks in the area are locally folded and faulted, and upward diapiric movement of salt is indicated by the domal bulges in which salt is or was exposed (Mannion, 1963). Tectonic movement along faults in the Las Vegas shear zone, which passes about $30 \mathrm{~km}$ southwest of the evaporite mass, occurred as recently as 10,000 years ago, and there is evidence that the fault on the west side of Virgin Valley has been active during the Holocene (Netherland, Sewell and Associates, 1977).

Several boreholes drilled in the Detrital Valley area of northwestern Arizona found salt at a depth of 125-180 m (Pierce and Rich, 1962). Longwell (1928) mentioned the occurrence of gypsum in the Muddy Creek Formation, but anhydrite has not been reported. The salt here is at least $150-210 \mathrm{~m}$ thick, has few impurities, and is largely recrystallized. Based on drilling, the salt is known to extend over more than several square kilometers. Although the salt is probably part of the Muddy Creek Formation, its exact relationship to the Virgin Valley deposit has not been established.

\section{Other Basins in Arizona}

Four other basins in the Basin and Range Province of Arizona that contain evaporites are the Red Lake,
Verde Valley, Tonto, and Safford Valley basins (fig. 2.63). Little is known about the subsurface in these basins, and thus knowledge of their evaporites is limited.

The Red Lake basin in northwestern Arizona contains a thick mass of upper Tertiary (Miocene) rock salt about $450 \mathrm{~m}$ below the surface. The basin is in the northwest-trending Hualapai Valley, about $45 \mathrm{~km}$ north of Kingman in Mohave County. About 1,200 m of salt was drilled in one borehole, but the base of the salt was not reached. Geophysical work, principally based on gravity data, indicates that the mass of salt might extend about $20 \mathrm{~km}$ along the length of Hualapai Valley, about $8 \mathrm{~km}$ perpendicular to the sides of the valley, and might be as thick as 3,000 $\mathrm{m}$ (Peirce, 1972, 1974, 1976). Anhydrite has not, however, been reported in this evaporite deposit. A brief discussion of this salt as a potential waste-repository unit was presented by Johnson and Gonzales (1978).

The Verde Valley basin in central Arizona contains a sequence of interbedded evaporites and fine-grained clastic rocks in the Verde Formation of Pliocene age (Twenter and Metzger, 1963; Eaton and others, 1972). Nonmarine evaporites in this area include thenardite, mirabilite, halite, and glauberite. Total thickness of the sequence is not known, but some beds consisting primarily of evaporites are as much as $20-27$ m thick. The total area known to contain evaporites is about $200 \mathrm{~km}^{2}$.

Eaton and others (1972) have shown that the Tonto basin contains deposits of halite. However, they did not present data concerning the thickness, depth, or character of the halite or any other evaporites that may be present.

Safford Valley basin, in the southeastern part of the State, contains rock salt and highly saline ground water (Eaton and others, 1972). A test well in the area found rock salt from a depth of 710-713 m, underlain by clay to a total depth of $716 \mathrm{~m}$.

\section{SOUTHERN NEVADA AND NEARBY AREAS-PERMIAN THROUGH TERTIARY}

Southern Nevada, as well as nearby parts of southwestern Utah, northwestern Arizona, and southeastern California, comprises a region that has many outcrops of gypsum beds that range in age from Permian through Tertiary (fig. 2.1). Some of the gypsum beds are reported to be about $30 \mathrm{~m}$ thick, and one is reported to be $30-90 \mathrm{~m}$ thick. Anhydrite has been found several meters back from the outcrop at several places. Few data are available on the sulfate beds in the subsurface, and most of the region has been deformed since deposition of the evaporite units. Principal references on Nevada include Stone and others (1920), Vanderburg (1937), 
Olson (1964), and Longwell and others (1965); references on Utah and Arizona are Stone and others (1920), Baker and others (1936), Withington (1964), Bissell (1969), Irwin (1971), and Rawson and Turner (1974); data on California are in reports by Ver Planck (1952) and Withington (1966).

Most of the evaporites in the region were deposited in a shelf or platform environment on the east side of the Cordilleran geosyncline. The region lies mainly within the central part of the Basin and Range Province, and is typified by elongate north-trending mountain ranges separated by wide topographic basins; the eastern part of the region is in the Colorado Plateau. The major episodes of deformation and igneous activity began in the Cretaceous Period and continued into Tertiary time. Thus, most of the evaporite-bearing strata have been involved in mild to complex folding, thrust faulting, plutonic and volcanic activity, and block faulting (Longwell and others, 1965).

Gypsum in southern Nevada is exposed in the uplifted blocks that form the Virgin, Muddy, Frenchman, and Spring Mountains. It occurs in the following outcropping formations: the Permian Toroweap and Kaibab Formations, the Triassic Moenkopi and Chinle Formations, the Tertiary Horse Spring and Muddy Creek Formations. Anhydrite has been found in some of these units as little as $5-60 \mathrm{~m}$ back from the outcrop, and undoubtedly it is the dominant form of sulfate in the moderate to deep subsurface.

The Spring Mountains contain the Arden or Blue Diamond area in which gypsum beds of the Toroweap and Kaibab Formations commonly are 2-5 m thick, but may be as much as $23 \mathrm{~m}$ thick (Longwell and others, 1965). Gypsum beds as much as $6 \mathrm{~m}$ thick have been commercially mined here for more than 50 years. At a depth of 30-60 m from the surface the gypsum grades into anhydrite. Steeply dipping beds of gypsum more than $15 \mathrm{~m}$ thick also are reported in the Kaibab Formation (also called Kaibab Limestone) south of this area in the northeast corner of San Bernardino County, Calif. (Ver Planck, 1952).

Frenchman Mountain and nearby areas contain gypsum in the Kaibab, Moenkopi, and Horse Spring Formations, and deposits in these units have been mined intermittently since 1938. Farther north, in the Muddy Mountains and vicinity, gypsum is present in the Toroweap, Kaibab, Chinle, and Horse Spring Formations. Gypsum beds in all these areas are commonly 2-15 m thick, although Jones and Stone (in Stone and others, $1920)$ reported that they were informed of a "massive body of pure white gypsum 30-90 m thick" that dips $40^{\circ}-70^{\circ}$ in the area south of Moapa. The Virgin
Mountains contain abundant gypsum beds. Most of them are in Permian strata, but some minor gypsum beds occur in Triassic and lower Tertiary formations.

Southwestern Utah and northwestern Arizona contain gypsum and anhydrite in the Permian Toroweap and Kaibab Formations, the Triassic Moenkopi Formation, and the Jurassic Carmel and Curtis Formations. Individual sulfate beds are typically $2-10 \mathrm{~m}$ thick, but units in the Toroweap and Curtis that are predominantly sulfate are reported to be $30-60 \mathrm{~m}$ thick. Much of this area is on the west side of the Colorado Plateau and is not as deformed as the rest of the region.

The Toroweap contains anhydrite in the subsurface and gypsum in outcrop from Wayne County, Utah, southwestward to northern Mohave County, Ariz. Sulfate beds are mainly in the upper part of the formation, and individual beds typically are $2-10 \mathrm{~m}$ thick. Rawson and Turner (1974) showed that in northwestern Arizona the upper part of the formation is a gypsum member $30-60 \mathrm{~m}$ thick that has thin interbeds of sandstone and carbonate.

The overlying Kaibab Formation consists mainly of limestone, but contains much gypsum, dolomite, and red beds in the upper part. The upper gypsiferous member is commonly $30-60 \mathrm{~m}$ thick, and individual gypsum beds are typically $2-10 \mathrm{~m}$ thick. Withington (1964) reported $15 \mathrm{~m}$ of white gypsum just south of La Verkin in Washington County, Utah.

The Moenkopi Formation of southwestern Utah and northwestern Arizona contains thin interbeds of gypsum that range from 1 to $3 \mathrm{~m}$ in thickness.

The Carmel Formation consists mainly of sandstone and shale, but also has interbeds of gypsum 3-15 m thick in much of the area. The unit is a southwestern extension of the thick evaporites in the Arapien Formation of central Utah.

Extensive deposits of gypsum in the Curtis Formation crop out in parts of Iron, Washington, and Kane Counties of southwestern Utah. Withington (1964), in summarizing the occurrences in this area, mentioned one bed that ranges from $2 \mathrm{~m}$ to as much as $30 \mathrm{~m}$ in thickness in the crest of anticlines, and also reported a location that has about $28 \mathrm{~m}$ of gypsum mixed with clay.

In southeastern California, a series of deformed gypsum beds of Permian age (probably Kaibab Formation) occurs with metamorphosed rocks in eastern Riverside County (Ver Planck, 1952; Withington, 1966). Lenses and irregular masses of gypsum range from 2 to $30 \mathrm{~m}$ in thickness and can be traced for short distances along the outcrop. Gypsum beds are steeply dipping and are intimately associated with gypsiferous schist, quartzite, and other metamorphosed rocks. 
Thus, moderately thick layers of anhydrite probably are present in the subsurface in parts of southern Nevada and nearby areas, but existing data do not permit an adequate description of the character, distribution, thickness, and depth of the anhydrite units. The region has been the site of structural deformation and igneous activity since deposition of the evaporites, and we are not sure if any areas exist where thick anhydrite is at moderate depth and is undeformed. Several outcropping units contain gypsum beds reportedly 30-90 m thick, and some of these probably grade into thick anhydrite units in the subsurface.

\section{CENTRAL UTAH-JURASSIC AND TERTIARY}

The Carmel, Arapien, and Summerville Formations (Jurassic) of central Utah (fig. 2.1) contain gypsum beds that typically are $2-10 \mathrm{~m}$ thick and are deformed locally to lenses and irregular masses as much as 30-90 m thick. A gypsum bed as much as $13 \mathrm{~m}$ thick also occurs in the Tertiary (Paleocene and lower Eocene) Flagstaff Limestone. Although all these units probably contain anhydrite in the subsurface, too few data are available on their subsurface character to confirm this. In the western part of this area, a thick sequence of salt in the Arapien Formation has flowed plastically and has distorted interbedded gypsum units along the Sevier and Sanpete Valleys. Principal references to Jurassic evaporites in central Utah are Gilliland (1951), Hardy (1952), Withington (1964), Pratt and others (1966), Moulton (1975), and Freeman (1976). Stanley and Collinson (1979) presented information on gypsum in the Flagstaff Limestone.

Strata in the eastern part of the region dip gently off the west flank of the San Rafael swell. They are, however, highly distorted, folded, and faulted in the western part of the region where thick beds of salt were deposited in a rift valley and subsequently were deformed into complex anticlinal structures. The western half of the region is part of the Basin and Range Province and also is part of the overthrust belt.

Gypsum beds in the Carmel and Summerville Formations can be traced for long distances along the western flank of the San Rafael swell. The Carmel Formation consists of 100-200 m of green shale and sandstone interbedded with limestone and white gypsum. Gypsum beds commonly range from 2 to $10 \mathrm{~m}$ in thickness and are restricted to the upper part of the formation. The Summerville, which is about $300 \mathrm{~m}$ above the Carmel, is composed mainly of sandstone and siltstone, but contains a bed of gypsum as much as $3 \mathrm{~m}$ thick. These undeformed strata dip gently westward and are about $1,000 \mathrm{~m}$ below the surface along the Emery-Sevier County line; they are 2,000-3,000 m deep across the east half of Sevier County.

The Arapien Formation consists of more than $2,500 \mathrm{~m}$ of evaporites and shale that fill a rift zone, $25 \mathrm{~km}$ wide and at least $100 \mathrm{~km}$ long, that trends northnortheast through Sevier and Sanpete Counties. Recent subsurface studies have shown the correlation of the Arapien with typical Carmel strata farther east (Moulton, 1975; Freeman, 1976).

Outcrops of the Arapien Formation in the Sevier Valley consist of red and gray shales interbedded with sandstone, limestone, salt, and lenses of gypsum (Pratt and others, 1966). Gypsum beds average about $8 \mathrm{~m}$ in thickness, but some of the lenses and irregular masses are locally $30-90 \mathrm{~m}$ thick. Such anomalous thickening is due to plastic flow of the rock in salt anticlines that have steeply dipping flanks of $20^{\circ}-40^{\circ}$. The presence of anticlinal folding in Holocene gravels in the valley shows that upward flowage of the plastic salt beds still continues. Depth to anhydrite is probably about $15-30 \mathrm{~m}$ in the anticlines, and depth to the Arapien evaporites ranges from 1,800 to $3,600 \mathrm{~m}$ in the seven wells drilled into the salt away from the crest of the anticlines.

The Flagstaff Limestone (Paleocene and Eocene) consists of limestone, dolomite, mudstone, and gypsum deposited in a large lake that covered much of central Utah (Stanley and Collinson, 1979). The gypsiferous interval, which is as much as $30 \mathrm{~m}$ thick, consists of nodular gypsum in dolomite and bedded gypsum with alternating laminae of gypsum and black-brown carbonaceous mudstone. The bedded gypsum zone is as much as $13 \mathrm{~m}$ thick and can be identified over an area of about $500 \mathrm{~km}^{2}$ in the Wasatch Plateau.

\section{EASTERN GREAT BASIN-PERMIAN}

A large region in the eastern part of the Great Basin contains gypsum and anhydrite deposits in the Permian Pequop and Loray Formations (fig. 2.1). The region includes parts of White Pine and Elko Counties in northeastern Nevada and parts of Millard, Juab, and Tooele Counties in northwestern Utah. Outcropping gypsum beds range in thickness from several meters to perhaps 30-60 m. A deep petroleum test well in Nevada 
penetrated a thick section of Permian gypsum and anhydrite interbedded with limestone and siltstone (Lintz, 1957). Data on outcropping strata were presented by Hodgkinson (1961) and Bissell (1964, 1970).

Strata in this part of the Basin and Range Province are deformed as a result of Tertiary block faulting. Gypsum beds, which are exposed in the uplifted mountain blocks, are undoubtedly present as anhydrite at moderate depths in the mountain blocks or where deeply buried in the down-dropped valleys.

Outcrops of the Pequop and Loray Formations contain interbeds of gypsum in a sequence that consists mostly of siltstone and limestone. Most of the gypsum bcds apparently are 2-10 m thick, although Bissell (1964) described a 28-m-thick unit of the Loray in White Pine County that consists of hard gypsum and anhydrite, earthy gypsum, and minor interbeds of clay. Hodgkinson (1961) illustrates a columnar section in the Gold Hill district of Tooele County, Utah, where about $60 \mathrm{~m}$ of the Summit Springs is mainly alabaster gypsum that contains thin interbeds of dolomite. Presumably these sulfate beds are anhydrite at depths as shallow as $15-30 \mathrm{~m}$. A large area on the east side of the Great Basin is underlain by these Permian strata, and thick, undeformed anhydrite beds may be present at moderate depth in some part of this region.

The deep borehole reported by Lintz (1957) is the Standard Oil Company of California and Continental Oil Company No. 1 Summit Springs Unit well, and is in sec. 32, T. 20 N., R. 60 E., in the central part of White Pine County, Nev. Anhydrite was first found at a depth of 457 $\mathrm{m}$ in this well and was present as interbeds for the next $1,567 \mathrm{~m}$. The thicker units that are predominantly anhydrite, as reported by Lintz (1957), include $34 \mathrm{~m}$ (at a depth of $457 \mathrm{~m}$ ), $26 \mathrm{~m}$ (at a depth of $518 \mathrm{~m}$ ), $46 \mathrm{~m}$ (at a depth of $566 \mathrm{~m}$ ), and $26 \mathrm{~m}$ (at a depth of $1,403 \mathrm{~m}$ ). Anhydrite in these units is white, and is interbedded with gray or red siltstone and gray limestone. This series of anhydrite beds is assigned to the Summit Springs Evaporite Member of the Pequop Formation.

\section{NORTHWESTERN NEVADA-TRIASSIC OR JURASSIC}

Gypsum is reported at seven separate localities in Pershing, Lyon, and Mincral Counties in northwestern Nevada (fig. 2.1). Most of the deposits are rather small, although several of them (especially the Empire and Lovelock deposits in Pershing County) are commercially important and have been quarried to make gypsum products. The geologic ages of these deposits are not known, but their geologic setting and general character are similar and all deposits are believed to be Triassic or Jurassic in age. Limited data on these gypsum deposits were given by Stone and others (1920), Olson (1964), Archbold (1969), and Johnson (1977).

Gypsum outcrops in this part of the Basin and Range Province cover small areas that are structurally complex. They are typically faulted and folded, and are closely associated with metasedimentary rocks. The gypsum typically occurs as lenses or irregular beds that are reported to be as much as 30-60 m thick. Boreholes drilled in the gypsum deposits have found anhydrite at depths of 20-100 m below the surface.

Thick layers of undisturbed anhydrite may be present in the subsurface of northwestern Nevada, but too few boreholes penetrate the Triassic and Jurassic strata of the region to allow description of the character, distribution, thickness, and depth of the anhydrite layers. Because of the general structural complexity of the region, special attention must be paid to the structural setting of any thick anhydrite subsequently discovered in northwestern Nevada.

\section{WESTERN IDAHO AND EASTERN OREGON-TRIASSIC}

Gypsum beds of Triassic age crop out along and near the Snake River in Washington County, Idaho, and Baker County, Oreg. (fig. 2.1). The gypsum occurs in irregular lenses as much as $10 \mathrm{~m}$ thick and grades into anhydrite at shallow depth in one of the several surface mines of the area. The area is structurally complex, and the gypsum locally is faulted and contorted and is associated with chlorite schist. Moore (1937) and McDivitt (1952) reported on these deposits.

\section{SOUTHERN CALIFORNIA-TERTIARY}

The southern half of California has many scattered but small deposits of gypsum that are of late Tertiary (Miocene and Pliocene) age (fig. 2.69). Individual gypsum beds of nonmarine origin typically range from 1 to $10 \mathrm{~m}$ in thickness, but lenses of gypsum are as much as $30 \mathrm{~m}$ thick along the crests of folds where the rock has been squeezed from the flanks. Most deposits are folded and faulted and have moderate to steep dips. Principal reports on California deposits are those by Ver Planck (1952, 1957), Withington (1966), and Runvik (1972). 


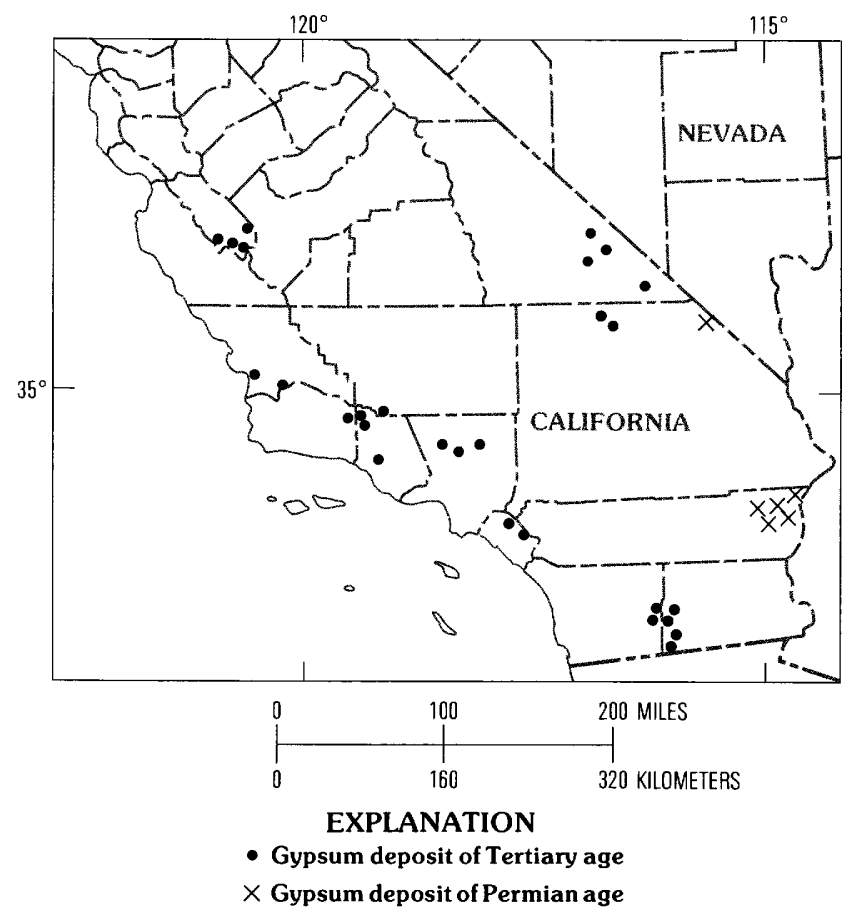

Figure 2.69. Map showing location of gypsum deposits in southern California (modified from Ver Planck, 1952; Withington, 1962).

The thickest deposits are in the Fish Creek Mountains of Imperial County where gypsum beds are folded and squeezed to a thickness of as much as $30 \mathrm{~m}$. The normal dip of strata in the area is about $25^{\circ}-35^{\circ}$ toward the axis of a shallow synclinal basin. In an open-pit mine, anhydrite lenses are present at a depth of $15 \mathrm{~m}$; these lenses gradually increase downward until the entire mass becomes anhydrite.

Other moderately thick deposits include 3-10 m of gypsum in the Quatal Canyon area of Ventura County and $3 \mathrm{~m}$ of gypsum in parts of Santa Barbara and Ventura Counties. 


\title{
SECTION 3. Physical Properties of Anhydrite
}

\author{
By SHARON F. DIEHL and WILLIAM Z. SAVAGE
}

\section{INTRODUCTION}

The following is a compilation of test data from the literature on the mechanical and thermal properties of anhydrite. The properties included are density, porosity, thermal conductivity, Young's modulus, Poisson's ratio, shear modulus, and sonic velocity. The data are presented in tables and include brief explanations where necessary. Discrepancies in the thermal properties for anhydrite (table 3.1) are due to lithologic factors-bedding, schistosity, or fracturing, as well as to experimental error.

Table 3.1. Thermal properties of anhydrite

[Leaders (- - ) indicate no data; $\mathrm{g} / \mathrm{cm}^{\mathrm{s}}$, grams per cubic centimeter; cal $/(\mathrm{cm})(\mathrm{s})\left({ }^{\circ} \mathrm{C}\right)$, calories per $($ centimeter $)($ second $)(\mathrm{degree} \mathrm{Celsius}) ; \mathrm{cal} /(\mathrm{g})\left({ }^{\circ} \mathrm{C}\right)$, calories per (gram)(degree Celsius)]

\begin{tabular}{|c|c|c|c|c|c|c|}
\hline $\begin{array}{l}\text { Sample } \\
\text { locality }\end{array}$ & $\begin{array}{l}\text { Densitty } \\
\left(\mathrm{g} / \mathrm{cm}^{3}\right)\end{array}$ & 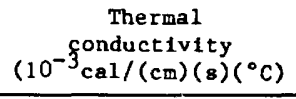 & $\begin{array}{c}\text { Heat } \\
\text { capac1ty } \\
\left(\mathrm{cal} /(\mathrm{g})\left({ }^{\circ} \mathrm{C}\right)\right. \\
\end{array}$ & $\begin{array}{c}\text { Average coefficient } \\
\text { of linear } \\
\text { thermal expanston }\end{array}$ & Remarks & References \\
\hline $\begin{array}{l}\text { Lotchberg } \\
\text { tunnel, } \\
\text { Switzerland. }\end{array}$ & 2.91 & 13.4 & --- & -- & $\begin{array}{l}\text { Average of } 3 \\
\text { samples }\end{array}$ & Clark (1966). \\
\hline Switzerland------ & -2.96 & 13.0 & 0.215 & -- & --- & Rybach (1975). \\
\hline Red Sea--_-_-_- & -2.83 & 10.8 & -- & -- & $\begin{array}{l}\text { Red Sea site } \\
225 ; \text { average } \\
\text { of } 6 \text { samples. }\end{array}$ & $\begin{array}{l}\text { Wheildon, Evans, } \\
\text { and Girden } \\
(1974) \text {. }\end{array}$ \\
\hline Do-------- & -2.91 & 12.3 & -- & $-\cdots$ & $\begin{array}{l}\text { Red Sea site } \\
227 \text {; average } \\
\text { of } 3 \text { samples } \\
\text { deeper core. }\end{array}$ & Do. \\
\hline $\begin{array}{l}\text { Asmanf L1mestone, } \\
\text { Gach Saran, Iran. }\end{array}$ & $\begin{array}{r}2.95 \\
2.94 \\
2.95 \\
2.95 \\
2.94 \\
2.95 \\
2.95 \\
2.94 \\
2.96 \\
2.94 \\
---\end{array}$ & $\begin{array}{l}8.2 \\
8.5 \\
8.4 \\
7.3 \\
7.0 \\
7.0 \\
7.8 \\
7.9 \\
8.0 \\
7.7 \\
--.\end{array}$ & $\begin{array}{c}-\cdots \\
--- \\
--- \\
--- \\
--- \\
--- \\
-- \\
---\end{array}$ & at $20^{\circ}$ to $200^{\circ} \mathrm{C}$ & $\begin{array}{l}\text { Rock probably } \\
\text { contains gypsum, } \\
\text { which would } \\
\text { account for lower } \\
\text { values of heat } \\
\text { conductivity. }\end{array}$ & Zierfuss (1969). \\
\hline $\begin{array}{l}\text { Bancroft, Ontario, } \\
\text { Canada. }\end{array}$ & , --- & -- & -- & $12.2 \times 10^{-6}$ at $20^{\circ} \mathrm{C}$ & -- & Evans (1979). \\
\hline England--------- & $\begin{array}{l}2.95 \\
2.92 \\
2.93 \\
2.92 \\
\\
2.93 \\
2.85\end{array}$ & $\begin{array}{l}14.1 \\
12.7 \\
13.0 \\
13.3 \\
13.5 \\
13.5\end{array}$ & $\begin{array}{l}-- \\
-- \\
--- \\
--\end{array}$ & $\begin{array}{l}--- \\
\cdots-- \\
\cdots- \\
\cdots-\end{array}$ & $\begin{array}{l}\text { Light-gray anhydrite. } \\
\text { Light-pink anhydrite. } \\
\text { Dolomitic anhydr1te, } \\
>80 \text { percent } \mathrm{CaSO}_{4} \\
-\end{array}$ & $\begin{array}{l}\text { Bullard and } \\
\text { Niblett (1951). }\end{array}$ \\
\hline Gulf coast-- & 2.93 & 13.7 & $\cdots$ & -- & $\begin{array}{l}\text { Gulf coast, average } \\
\text { of } 3 \text { samples. }\end{array}$ & $\begin{array}{l}\text { Herrin and } \\
\text { Clark (1956). }\end{array}$ \\
\hline New Mexico-- & 2.82 & 12.9 & -- & --- & $\begin{array}{l}\text { Carlsbad, N. Mex.; } \\
\text { average of } 3 \text { samples. }\end{array}$ & -- \\
\hline Iran- & -- & 11.7 & --- & --- & -- & Coster (1947). \\
\hline
\end{tabular}


Table 3.2 Ultimate strength of anhydrite

[MPa, $10^{6}$ Pascals; Pa, Pascals]

\begin{tabular}{|c|c|c|c|c|}
\hline $\begin{array}{l}\text { Anhydrite } \\
\text { sample } \\
\text { locality }\end{array}$ & $\begin{array}{l}\text { Confining } \\
\text { pressure } \\
\text { (MPa) }\end{array}$ & $\begin{array}{c}\text { Temperature } \\
\text { (degrees } \\
\text { Celsius) }\end{array}$ & $\begin{array}{l}\text { U1timate } \\
\text { strength } \\
\left(\begin{array}{lll}\mathrm{X} \quad 10^{8} \mathrm{~Pa}\end{array}\right)\end{array}$ & Reference \\
\hline Blaine, 0kla.-- & $\begin{array}{r}0 \\
50 \\
100 \\
200\end{array}$ & $\begin{array}{l}24 \\
24 \\
24 \\
24\end{array}$ & $\begin{array}{l}1.28 \\
2.76 \\
3.73 \\
4.95\end{array}$ & $\begin{array}{l}\text { Handin and Hager } \\
(1957) .\end{array}$ \\
\hline Do--- & $\begin{array}{l}100 \\
100 \\
100 \\
100 \\
100 \\
100 \\
200 \\
200 \\
200 \\
200 \\
200 \\
200\end{array}$ & $\begin{array}{r}24 \\
24 \\
150 \\
150 \\
300 \\
300 \\
24 \\
24 \\
150 \\
150 \\
300 \\
300\end{array}$ & $\begin{array}{l}3.73 \\
3.45 \\
3.31 \\
3.24 \\
3.73 \\
4.35 \\
4.95 \\
5.17 \\
5.56 \\
5.20 \\
6.62 \\
6.03\end{array}$ & $\begin{array}{l}\text { Handin and Hager } \\
(1958) .\end{array}$ \\
\hline Germany-------- & $\begin{array}{c}0.1 \\
20 \\
30 \\
40 \\
50 \\
75 \\
100 \\
100 \\
50\end{array}$ & $\begin{array}{r}25 \\
25 \\
25 \\
25 \\
25 \\
25 \\
25 \\
150 \\
150\end{array}$ & $\begin{array}{l}0.80 \\
2.00 \\
2.40 \\
2.60 \\
2.80 \\
3.40 \\
3.80 \\
3.50 \\
2.70\end{array}$ & $\begin{array}{l}\text { Müller and } \\
\text { Siemes }(1974)\end{array}$ \\
\hline Alberta, Canada- & $\begin{array}{r}0 \\
17 \\
35 \\
52 \\
69\end{array}$ & $\begin{array}{l}24 \\
24 \\
24 \\
24 \\
24\end{array}$ & $\begin{array}{r}.41 \\
1.08 \\
1.45 \\
1.88 \\
2.08\end{array}$ & C1ark (1966). \\
\hline $\begin{array}{l}\text { Hockley Dome, } \\
\text { Houston, Tex. }\end{array}$ & $\begin{array}{l}314 \\
310 \\
329 \\
317\end{array}$ & $\begin{array}{r}24 \\
24 \\
150 \\
300\end{array}$ & $\begin{array}{l}2.52 \\
5.54 \\
1.00 \\
1.82\end{array}$ & Do. \\
\hline Texas--- & 101 & 24 & 3.24 & Do. \\
\hline
\end{tabular}

\section{THERMAL PROPERTIES}

Thermal conductivity is a measure of heat conducted in a unit time across an element of surface (Clark, 1966). It is a function of temperature, pressure, and crystallography of the mineral concerned. Seipold and Gutzeit (1974) determined from uniaxial tests on anhydrite that pressure had little effect on thermal conductivity, either perpendicular to or parallel to layering.

Zierfuss (1969) determined that samples of dolomite or limestone composed of more than 50 percent anhydrite were the best heat conductors. He mentioned porosity as an important factor because heat conductivity decreases as porosity increases. Robertson (1979, fig. 13) showed the decrease of thermal conductivity with temperature for the temperature range $0^{\circ}$ to $110^{\circ} \mathrm{C}$ to be $-2.95 \times 10^{-3} \mathrm{cal} / \mathrm{cm} \mathrm{sec} / 100^{\circ} \mathrm{C}$.

\section{MECHANICAL PROPERTIES}

Ultimate strength is the maximum stress difference a material can sustain under given conditions of pressure, temperature and strain rate. Ultimate strength values for 
anhydrite from various localities in the world are listed in table 3.2 .

The ultimate strength of anhydrite increases with increasing confining pressure at room temperature. Anhydrite behaves brittlely at or below $50 \mathrm{MPa}$ confining pressure and at small strains (1-3 percent). Typical stress-strain curves for anhydrite are shown in figure 3.1.

At $100-300 \mathrm{MPa}$ confining pressure, the elastic limit is reached at 1-3 percent strain. Beyond the elastic limit, curves are nearly horizontal (fig. 3.1); there is no change in strength with continuing flow. At higher confining pressures (300-400 MPa), work hardening (an increase in strength with continuing flow) is evident. Thus, anhydrite can undergo a large permanent deformation at high confining pressure without fracturing (fig. 3.1).

Müller and Briegel (1978) investigated the effect of temperature and strain rate on the strength of anhydrite. Curves for the lower "geologic" strain rates were extrapolated. Figure 3.2 shows that decreasing strain rate causes a decrease in strength for given temperatures in excess of $100^{\circ} \mathrm{C}$. Ultimate strength generally decreases as temperature rises, whereas ductility increases.

Müller and Briegel (1977) determined the effect of grain size on the strength of anhydrite. Fine-grained anhydrite is stronger at room temperature than coarsegrained anhydrite; the opposite is true at temperatures higher than $400{ }^{\circ} \mathrm{C}$.

Anhydrite deforms by translation gliding along the (001) and (012) planes and by twin gliding along the (101) plane (Ramez, 1976).

Stephens (1964) observed a phase transition (a change in optical domains) in compressing anhydrite, beginning at $1,960 \pm 5 \mathrm{MPa}$ and ending at $3,400 \mathrm{MPa}$, with a volume decrease of 4.1 percent. A transition also was noted in a sample of rock salt containing 15.7percent

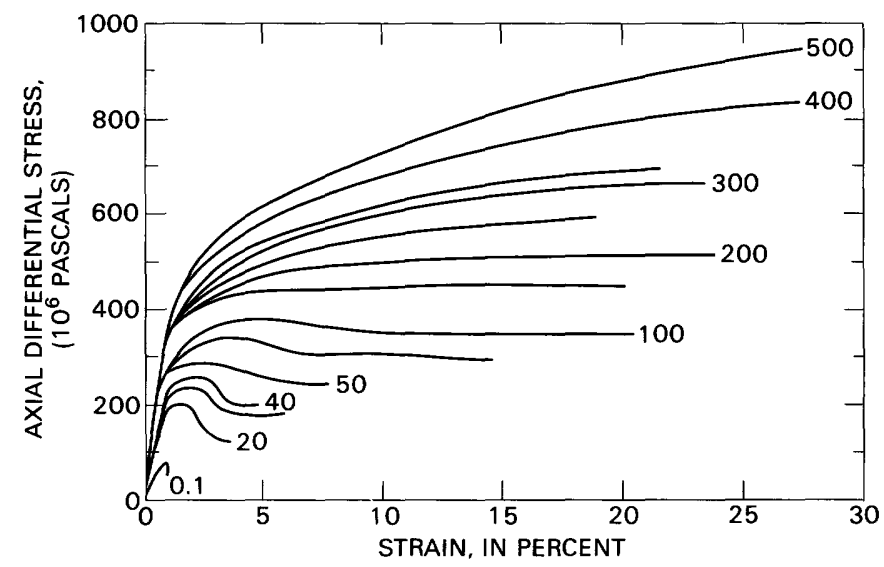

Figure 3.1. Typical stress-strain curves for anhydrite for various confining pressures (modified from Miller and Siemes, 1974).

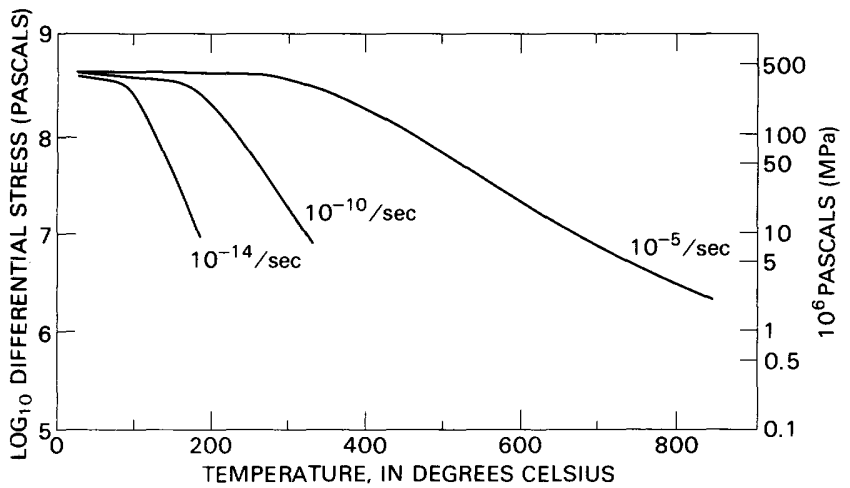

Figure 3.2. Strength of anhydrite at 10-percent strain and different strain rates. The confining pressure is $150 \mathrm{MPa}$ (modified from Müller and Briegel, 1978).

anhydrite, but at a higher pressure (2,450 MPa). Kahn (1975) also reported a phase transition in anhydrite that was induced by strain from a nuclear explosion within the Tatum salt dome. Results from these two experiments indicate that a high-pressure polymorph of anhydrite exists.

\section{ELASTIC PROPERTIES}

The elastic moduli values in table 3.3 show that anhydrite is anisotropic along its orthorhombic crystal directions. The whole-rock values in table 3.4 are more realistic, because single crystals of anhydrite are rare in nature.

The sonic-velocity values in table 3.5 are field data, except for the single laboratory value reported by Schwerdtner and others (1965). The laboratory value, which is based on calculations from a single crystal of anhydrite, is low compared with the field data.

\section{DISCUSSION}

Compared with halite, anhydrite has several advantages for nuclear-waste isolation. It has a higher melting point than halite, and ductile deformation occurs at higher temperatures. Its thermal conductivity is comparable to halite and its ultimate strength at low confining pressures is two to three times that of halite. However, brittle behavior at low continuing pressures may cause enhanced fracturing in the vicinity of the repository. 
Table 3.3. Mechanical properties of single crystals of anhydrite (modified from Schwerdtner and others, 1965)

[Subscripts indicate unit-cell dimensions: 1, parallel to c-axis; 2, parallel to b-axis; and s, parallel to a-axis. GPa, $10^{9} \mathrm{Pascals;}$

\begin{tabular}{|c|c|c|c|c|c|c|c|c|c|c|c|}
\hline \multicolumn{3}{|c|}{$\begin{array}{l}\text { Young's modulus } \\
\qquad(\mathrm{GPa})\end{array}$} & \multicolumn{3}{|c|}{$\begin{array}{l}\text { Shear modulus } \\
\text { (GPa) }\end{array}$} & \multicolumn{6}{|c|}{ Poisson's ratio } \\
\hline $\mathrm{E}_{1}$ & $\mathrm{E}_{2}$ & $\mathrm{E}_{3}$ & $\mathrm{G}_{12}$ & $\mathrm{G}_{13}$ & $\mathrm{G}_{23}$ & $\mu_{12}$ & $\mu_{13}$ & $\mu_{21}$ & $\mu_{23}$ & $\mu_{31}$ & $\mu_{32}$ \\
\hline 91.0 & 175.1 & 104.3 & 9.2 & 26.5 & 32.5 & 0.069 & 0.116 & 0.136 & 0.274 & 0.134 & 0.160 \\
\hline
\end{tabular}

Table 3.4 Mechanical properties of whole-rock anhydrite

[Leaders (- -) indicate no data; $\mathrm{g} / \mathrm{cm}^{3}$, grams per cubic centimeter; GPa, $10^{9}$ Pascals; MPa, $10^{6}$ Pascals]

\begin{tabular}{|c|c|c|c|c|c|c|c|}
\hline $\begin{array}{l}\text { Density } \\
\left(\mathrm{g} / \mathrm{cm}^{3}\right)\end{array}$ & $\begin{array}{l}\text { Porosity } \\
\text { (volume } \\
\text { percent) }\end{array}$ & $\begin{array}{l}\text { Young's } \\
\text { modulus } \\
\text { (GPa) }\end{array}$ & $\begin{array}{l}\text { Modulus of } \\
\text { rigidity } \\
\quad(\mathrm{GPa})\end{array}$ & $\begin{array}{l}\text { Poisson's } \\
\text { ratio }\end{array}$ & $\begin{array}{l}\text { Cohesion } \\
\text { (MPa) }\end{array}$ & Remarks & References \\
\hline 2.93 & 0.44 & 12.0 & --- & --- & 43.0 & $\begin{array}{l}\text { Sample } 95.0 \\
\text { percent } \mathrm{CaSO}_{4} .\end{array}$ & $\begin{array}{l}\text { Müller and } \\
\text { Briegel (1977). }\end{array}$ \\
\hline 2.93 & .54 & 26.0 & -- & -- & 42.0 & $\begin{array}{l}\text { Sample } 90.8 \\
\text { percent } \mathrm{CaSO}_{4}\end{array}$ & Do. \\
\hline 3.02 & -- & $\begin{array}{l}72.0 \text { to } \\
74.0\end{array}$ & 28.0 & 0.295 & -- & -- & Clark (1966). \\
\hline-- & -- & 75.0 & -- & .250 & -- & $-\infty$ & $\begin{array}{l}\text { Hofer and Menzel } \\
\quad(1964)\end{array}$ \\
\hline--- & -- & --- & -- & $\begin{array}{l}.385 \text { to } \\
.323\end{array}$ & -- & -- & Link (1962). \\
\hline
\end{tabular}

Table 3.5 Sonic velocities of anhydrite

$[\mathrm{km} / \mathrm{s}$, kilometers per second]

Sonic

velocity

$(\mathrm{km} / \mathrm{s})$

Remarks

References

4.10 United States midcontinent and Gulf Coast

5.00

3.51

4.64

4.95
Bashkir and Tatar, USSR .............

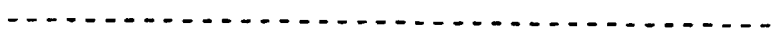

Average of 3 samples; Red Sea site 225-..

Average of 3 samples; Red Sea site 227...
Clark (1966).

Do.

Schwerdtner and others (1965).

Wheildon and others (1974). Do. 


\title{
SECTION 4. Hydrogeology of Anhydrite
}

\author{
By WILLIAM THORDARSON
}

Data are sparse on the hydrogeology of anhydrite. Therefore, only information on the general hydrogeologic properties of anhydrite as observed in outcrops, tunnels, mines, wells, and springs is presented.

\section{POROSITY, HYDRAULIC CONDUCTIVITY, AND TRANSMISSIVITY OF ANHYDRITE}

Anhydrite is apparently a confining bed if it has no fractures and permeable interbeds and if it has not been dissolved or hydrated to gypsum. Fractures depend both on how the anhydrite was formed and on how much it has been structurally deformed. For example, bedded anhydrite may have few fractures, whereas anhydrite in the cap rock of salt domes may have many fractures because of considerable structural deformation. Permeable interbeds or permeable impurities in anhydrite may consist of salt, sandstone, siltstone, or limestone. Dissolution of anhydrite or associated gypsum by ground water may form openings along bedding planes, widened fractures, karst holes, or even intercrystalline holes.

The data presented here on porosity, hydraulic conductivity, and transmissivity of bedded anhydrite, anhydrite in the cap rock of salt domes, and gypsum are from tunnels, mines, wells, and springs (table 4.1).

\section{Hydraulic Characteristics of Bedded Anhydrite}

\section{Intercrystalline porosity and hydraulic conductivity}

Data for the intercrystalline porosity of bedded anhydrite and bedded gypsum from a few scattered localities in the United States and elsewhere is presented in table 4.2. The geologic sources of the samples are not well described, and some may be from cap rock of salt domes. The purity of the samples is not described, except for the samples of dolomitic anhydrite from Switzerland that are 55-95 percent anhydrite. The mean intercrystalline porosity of 37 samples of bedded anhydrite is 1.1 percent, and the range is from 0.0 to 4.7 percent. The mean intercrystalline porosity of 34 samples of bedded gypsum is 15.9 percent, and the range is from 0.1 to 24.8 percent.

The intracrystalline porosity within cleavage planes of anhydrite crystals contained in dolomite of the San Andres Limestone, N. Mex., is the same as or greater than the intercrystalline porosity between dolomite crystals (Waldschmidt and others, 1956). Nodular anhydrite in the Prairie Formation in the Williston basin of Canada may have a permeable granular matrix but the organic matrix may be more impermeable than the granular matrix (Shearman and Fuller, 1969).

The intercrystalline hydraulic conductivity of bedded anhydrite is probably extremely low because anhydrite beds make impermeable seals in many oil fields. The low intercrystalline hydraulic conductivity of bedded anhydrite may be due primarily to the dense fabric of compacted, flat, lath-shaped anhydrite crystals (Shearman and Fuller, 1969). A dolomitic anhydrite in the Wellington Formation, Okla., had a hydraulic conductivity that was nearly zero (Blazenko, 1964). Ibrahim and Katz (1972) also reported a sample of anhydrite with a hydraulic conductivity equal to zero, as indicated by unsuccessful injection of mercury in a porosity test.

\section{Fracture porosity and hydraulic conductivity}

The following observations suggest that the fracture porosity of bedded anhydrite is probably extremely low. Bedded anhydrite forms an impermeable seal for oil in many oil fields (Edie, 1958; Sharma, 1966; Ells, 1967; Shearman and Fuller, 1969). A layer of anhydrite and dolomite in Michigan acts as a seal that prevents dissolution of underlying salt (Dellwig, 1955). Fractures are common in limestones in the oil fields of Saskatchewan, Canada, but they are absent or rare in associated anhydrite beds (Edie, 1958). Impermeable anhydrite makes up 45 percent of the Cedar Keys Limestone in Florida (Wilson and others, 1973). Hydraulic characteristics of either anhydrite or limestone in the Cedar Keys Limestone could not be determined during hydraulic injection tests in a single well. Therefore, the fracture porosity of bedded anhydrite generally is inferred to be low, even though quantitative laboratory measurements have not been made. 
Table 4.1. Hydrologic data from tunnels, mines, wells, and springs

[yr, year; $\mathrm{km}$, kilometer; $\mathrm{m}$, meter; $\mathrm{cm}$, centimeter, $\mathrm{L} / \mathrm{min}$, liters per minute; $\mathrm{m}^{\mathrm{s}}$, cubic meters; $\mathrm{m}^{2}$, square meters]

\begin{tabular}{lll}
\hline \multicolumn{1}{c}{ Location } & \multicolumn{1}{c}{$\begin{array}{c}\text { Formation } \\
\text { and age }\end{array}$} & Rock type \\
\hline $\begin{array}{l}\text { Water-diversion tunne1, } \\
\text { La Lechere, France. }\end{array}$ & Unknown--- & Anhydrite-- \\
& & \\
Railway tunne1, & --- do---- & Anhydrite-- \\
Le Braus, France. & &
\end{tabular}

Le Braus, France.

Water-diversion tunnel, Tignes, France.

Water-diversion tunnel,

La Courbaisse, France.

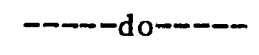

Anhydrite; shale.

Anhydrite--

Do-

Triassic----

Anhydrite;

Water-diversion

tunne1, Saint-Jean

Maurienne, France.
Triassic--- $\quad$ Anhydrite;

gypsum;

dolomitic

limestone

in diapir.
Comments

Reference

Walls and ceiling have not expanded and no rockfalls have occurred in $10 \mathrm{yr}$.

In one place, water seeps through

sandy beds in anhydrite and hydrates

it to gypsum.

$100 \mathrm{~m}$ from the entrance, abundant flow of water streams down wall, but no expansion has occurred. Other places have permeable interbeds of sand or clay, and gypsification of anhydrite has formed slabs of raised crust on wall. In $40 \mathrm{yr}$, walls arched Inward or caved in, floor raised or lowered $0.5 \mathrm{~m}$, and pillars dislocated.

Anhydrite appears perfectly dry and dense without visible fractures, but contains many veins of gypsum. Shale surrounding anhydrite is highly fractured and has abundant inflows of water.

Anhydrite has marked schistosity and a network of open fractures. Gypsum growing in fractures pushes blocks of $f$ wall.

Sahores (1962).

Do.

Do.

Anhydrite is dense and completely dry for $750 \mathrm{~m}$. Gypsum in pulverized chaotic zone $80 \mathrm{~m}$ long has inflows of water in roof. Rock bursts in anhydrite may or may not be due to expansion during gypsification.

Triassic is completely dry; impervious cover of shales of Liassic protected Triassic from infiltration of water.
Barber and

(1955).

Do.

and


Hauenstein tunnel, Germany.

Kappelisberg tunnel

Potash mines, Germany.

Mine of Grozon, near Arbois, France.

Mine, Victor, N.Y.

Mines, 0akfield, N.Y.

Mines, Akron, N.Y.

Shaft, Buffalo, N.Y.

Mine, Garbutt, N.Y.

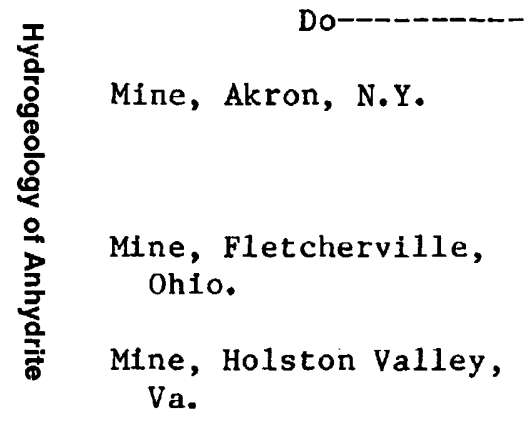

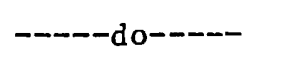

Anhydrite--

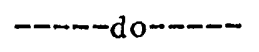

Permian----

Not reported

Anhydrite--

Camillus Shale,
Salina Group, Silurian.

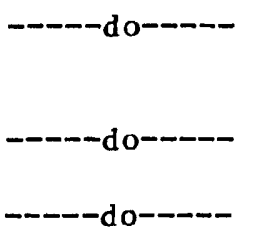

Camillus Shale, Silurian.

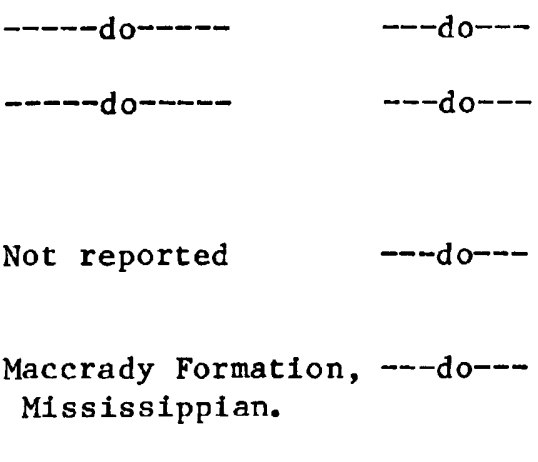

Not reported

Anhydrite in

Gypsum-$---d o--$ $--d o---$ $---d o---$
Heaving of rock floor may or may not be due to inflows of water.

do salt dlapir.

Flows of brine as much as $30 \mathrm{~L} / \mathrm{min}$ and some gas. Flows decreased over perlods of days or years.

8-m-wide mine with flat ceiling; never had rockfalls during perlod of more than 100 yr despite abundant condensation from air that coats anhydrite with film of water. Thin film of gypsum only. Water in gypsum layer at depth of 13-
$14 \mathrm{~m} ; 10,900-\mathrm{m}^{3}$-per-day pump could not draw down water in $6-\mathrm{m}^{2}$ shaft.

Some water in mines

Mine is dry

Considerable water inflow; $21,800 \mathrm{~m}^{3}$ per day pumped from shaft when first opened; now pumping much less.

Considerable water pumped from mine--

Workings filled with water

Water pumped from sumps into underground channe1 in gypsum.
Bendel (1948).

Do.

Baar (1977).

Sahores (1962).

Newland (1929);

Lintner (1937)

New1 and (1929).

Do.

Do.

Newland and Leighton (1910.

Do.

Do.

Adams and others

(1904).

Do.

Do. 
Table 4.1. Data from tunnels, mines, wells, and springs-Continued

\begin{tabular}{|c|c|c|c|c|}
\hline Location & $\begin{array}{l}\text { Formation } \\
\text { and age }\end{array}$ & Rock type & Comments & Reference \\
\hline $\begin{array}{l}\text { Mine, Centerville, } \\
\text { Iowa. }\end{array}$ & $----d o----$ & --- do--- & $\begin{array}{l}\text { Some water near surface. Artesian water } \\
\text { in shaft flows } 300 \mathrm{~m}^{3} \text { per day from } \\
1.2-\mathrm{m} \text {-thick limestone overlying gypsum. }\end{array}$ & $\begin{array}{l}\text { Stone and other: } \\
(1920) ; \text { Kay } \\
(1915) \text {. }\end{array}$ \\
\hline $\begin{array}{l}\text { Shaft, northeast } \\
\text { Michigan. }\end{array}$ & $\begin{array}{l}\text { Michigan Formation, } \\
\text { Mississippian. }\end{array}$ & --- do--- & Inflowing water flooded shaft-- & Grimsley (1904). \\
\hline $\begin{array}{l}\text { Quarry, Northern } \\
\text { peninsula, Michigan. }\end{array}$ & $\begin{array}{l}\text { Salina Group, } \\
\text { Silurian. }\end{array}$ & ---do--- & Water in quarry is source of trouble-- & Do. \\
\hline $\begin{array}{l}\text { Mine, Ontario, } \\
\text { Canada. }\end{array}$ & $\begin{array}{l}\text { Camillus Shale, } \\
\text { Silurian. }\end{array}$ & ---do-- & $\begin{array}{l}\text { Great inflows during sinking shaft to } 35- \\
\text { m depth. }\end{array}$ & Cole (1925). \\
\hline $\begin{array}{l}\text { Mine, Caledonia, } \\
\text { Ontario, Canada. }\end{array}$ & ---- do----- & ---do--- & $\begin{array}{l}\text { Unsuccessful attempt to sink shaft due to } \\
\text { trouble from ground water. }\end{array}$ & Dyer (1925). \\
\hline $\begin{array}{l}\text { Mine, Hockley salt } \\
\text { dome, Houston, Tex. }\end{array}$ & $\begin{array}{l}\text { Cap rock of salt } \\
\text { dome. }\end{array}$ & Gypsum--- & $\begin{array}{l}\text { Gypsum nearly watertight; only minor } \\
\text { water seeps into mine; difficulty sinking } \\
\text { shaft due to considerable water leakage } \\
\text { from overlying unconsolidated sediments } \\
\text { and cavernous limestone cap rock. }\end{array}$ & Stenzel (1943). \\
\hline $\begin{array}{l}\text { We11, ERDA No. 6, } \\
\text { New Mexico. }\end{array}$ & $\begin{array}{l}\text { Castile Formation, } \\
\text { Permian. }\end{array}$ & Anhydrite-- & $\begin{array}{l}\text { Significant flow of brine containing } \\
\mathrm{Na}_{2} \mathrm{SO}_{4} \text { and } \mathrm{H}_{2} \mathrm{~S}-\mathrm{rich} \text { gas at } \\
\text { depth of } 826 \mathrm{~m} \text {; no observed decrease } \\
\text { in flow during first } 10 \text { days, possibly } \\
\text { a brine pocket. }\end{array}$ & $\begin{array}{l}\text { Lambert and } \\
\text { Mercer }(1977) \text {; } \\
\text { Powers and } \\
\text { others }(1978)\end{array}$ \\
\hline $\begin{array}{l}\text { We11, ERDA No. 8, } \\
\text { New Mexico. }\end{array}$ & ----do---- & --- do--- & No flow of fluid in drill-stem test. & Do. \\
\hline $\begin{array}{l}\text { We11, ERDA No. } 9 \text {, } \\
\text { New Mex1co. }\end{array}$ & -----do---- & ---do--- & --_- & Do. \\
\hline $\begin{array}{l}\text { Belco oil well, } \\
\text { New Mexico. }\end{array}$ & -----do---- & --- do--- & $\begin{array}{l}\text { Significant flow of brine and } \mathrm{H}_{2} \mathrm{~S} \text { gas } \\
\text { decreased over } 1-\text { to } 2 \text {-day flow period, } \\
\text { indicating brine was in pocket. }\end{array}$ & $\begin{array}{l}\text { Lambert and } \\
\text { Mercer }(1977) \text {. }\end{array}$ \\
\hline $\begin{array}{l}\text { She11 Bootleg well, } \\
\text { New Mexico. }\end{array}$ & --a--do-n- & ---do--- & $\begin{array}{l}\text { Flow of brine decreased over several days } \\
\text { indicating brine was in pocket. }\end{array}$ & $\begin{array}{l}\text { J. W. Mercer } \\
\text { (written } \\
\text { commun., 1980) }\end{array}$ \\
\hline
\end{tabular}


011 well, sec. 23, T. 24 S., R. 29 E., New Mexico.

0 il well, Sec. 3 , T. 24 S., R. 29 E., New Mexico

Hole No. 3 , sec. 26 , T. 20 S., R. 26 E., New Mexico.

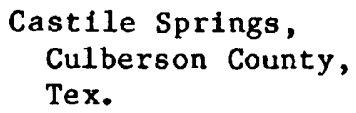

Stinking Spring, Culberson County, Tex.

Major Johnson Springs, Pecos River, N. Mex.

Di11on No. 91 oil we11, Pine Island oil field, Caddo Parish, La.

Wel1, Mich1gan---

Va.

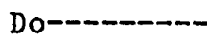

Black River Springs, Pecos Valley, N. Mex.

Blue Springs, Pecos Valley, N. Mex.

\begin{tabular}{|c|c|}
\hline$-----\mathrm{do}_{0}----$ & --- do -- \\
\hline$-----\mathrm{do}----$ & $---\mathrm{do}---$ \\
\hline $\begin{array}{l}\text { Castile Formation, } \\
\text { Permian. }\end{array}$ & $\begin{array}{l}\text { Gypsum, } \\
\text { anhydrite } \\
\text { sandy cla } \\
\text { cave brece }\end{array}$ \\
\hline$-----d o-----$ & $\begin{array}{l}\text { Anhydrite } \\
\text { and gypsur }\end{array}$ \\
\hline$-----d o----$ & $-m-d 0-$ \\
\hline $\begin{array}{l}\text { Seven Rivers } \\
\text { Formation, }\end{array}$ & $\begin{array}{l}\text { Gypsum and } \\
\text { dolomite. }\end{array}$ \\
\hline
\end{tabular}

Permian.

$$
\begin{array}{ll}
\text { Ferry Lake Anhy- } & \text { Anhydrite } \\
\text { drite, Cretaceous. } & \text { and } \\
\text { limestone. }
\end{array}
$$

Michigan Formation, Gypsum--Mississippian.

\section{Maccrady Formation Gypsum and Mississippian. salt.}

Unknown------- Gypsum---

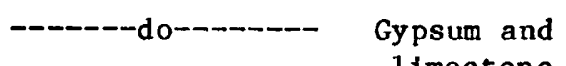

slight show of gas and hole full of salt water at depth of 559-561 m.

Exceptionally large yield of brine at depth of $526 \mathrm{~m}$.

Injection tests in $62-\mathrm{m}$ deep we 11 indicated very low to low trans missivity, hydraulic conductivity greatest in cave breccia.

May be artesian water from Delaware Mounta1n Group aquifer that underlies Castile Formation.

\section{do-}

Average 24,000 $\mathrm{m}^{3}$-per-day discharge; artesian water from leakage in gypusm at Lake McMillan 4.8-6.4 km to north. Tritium tracer test showed travel time between lake and springs to be about 3 months.

$14 \mathrm{~m}^{3}$-per-day of oll from well completed in anhydrite.

Strong pumps would be needed to mine gyps um.

Dry to total depth of 83

Brine at depth of $59 \mathrm{~m}$

Spring-
Do.

Cooper (1962).

Do.

Meinzer and others (1927).

Davis and Kirkland (1970)

Do.

Cox (1967):

Metnzer and

others (1927);

Reeder and

Thatcher (1963)

Crider (1929);

Spooner, (1935)

Grimsley (1904).

Eckel (1903).

Lee (1925).

Lee (1925). 
Table 4.1. Data from tunnels, mines, wells, and springs-Continued

\begin{tabular}{|c|c|c|c|c|}
\hline Location & $\begin{array}{l}\text { Formation } \\
\text { and age }\end{array}$ & Rock type & Comments & Reference \\
\hline Springs, Virginla---- & $\begin{array}{l}\text { Maccrady Formation } \\
\text { Mississippian. }\end{array}$ & Gypsum------ & $\begin{array}{l}\text { Springs containing high sulfate; may } \\
\text { originate in gypsum. }\end{array}$ & $\begin{array}{l}\text { Withington } \\
\text { (1965). }\end{array}$ \\
\hline $\begin{array}{l}\text { Salt springs, western } \\
\text { Kansas and Oklahoma. }\end{array}$ & Permian--- & $\begin{array}{l}\text { Red beds, } \\
\text { salt, and } \\
\text { anhydrite. }\end{array}$ & $\begin{array}{l}\text { Salt springs from dissolved salt and } \\
\text { anhydrite flow from red beds. }\end{array}$ & $\begin{array}{l}\text { Frye and Schof } \\
\text { (1942). }\end{array}$ \\
\hline $\begin{array}{l}\text { Big Gypsum Cave, } \\
\text { Evansville, Kans. }\end{array}$ & $\begin{array}{l}\text { Medicine Lodge } \\
\text { Gypsum Member, } \\
\text { Blaine Formation, } \\
\text { Permian. }\end{array}$ & Gypsum------ & Stream flows though gypsum cave. & $\begin{array}{l}\text { Grimsley and } \\
\text { Bailey (1899) }\end{array}$ \\
\hline $\begin{array}{l}\text { Springs, Axel Heiberg } \\
\text { Island, Canada. }\end{array}$ & Permian--- & Anhydrite--- & $\begin{array}{l}\text { Saline springs in center of Base Camp } \\
\text { Diapir. }\end{array}$ & Hoen $(1964)$. \\
\hline
\end{tabular}


Table 4.2 Intercrystalline porosity of bedded anhydrite.

[Leaders (---) indicate insufficient data]

\begin{tabular}{|c|c|c|c|c|}
\hline \multirow[b]{2}{*}{ Geologic source } & \multirow{2}{*}{$\begin{array}{c}\text { Number } \\
\text { of } \\
\text { samples }\end{array}$} & \multicolumn{2}{|c|}{$\begin{array}{l}\text { Porosity in } \\
\text { percent }\end{array}$} & \multirow[b]{2}{*}{ Reference } \\
\hline & & Mean & Range & \\
\hline Anhydrite, United States- & $\begin{array}{l}2 \\
1\end{array}$ & $\begin{array}{l}3.4 \\
0.0\end{array}$ & $2.8-4.0$ & $\begin{array}{l}\text { Raymer and Biggs (1963). } \\
\text { Ibrahim and Katz (1972). }\end{array}$ \\
\hline Dolomitic anhydrite, okla._- & We11 $\log$ & - & $1.0-3 \cdot 0$ & Blazenko (1964). \\
\hline Dolomitic anhydrite, Switzerland & 13 & 0.7 & $0.2-1.3$ & Mueller and Briegel (1977). \\
\hline $\begin{array}{l}\text { Anhydrite, Iran- } \\
\text { Gypsum, United States } \\
\text { Anhydritic gypsum, Switzerland- }\end{array}$ & $\begin{array}{r}21 \\
2 \\
1\end{array}$ & $\begin{array}{l}1.1 \\
2.6 \\
0.1\end{array}$ & $\begin{array}{l}0.1-4.7 \\
1.3-4.0\end{array}$ & $\begin{array}{l}\text { Zlerfuss }(1969) \text {. } \\
\text { Meinzer (1923). } \\
\text { Mueller and Briegel (1977). }\end{array}$ \\
\hline $\begin{array}{l}\text { Soft gypsum, France- } \\
\text { Gypsum, U.S.S.R. }\end{array}$ & $\begin{array}{r}30 \\
1\end{array}$ & $\begin{array}{l}17 \\
24.8\end{array}$ & - & $\begin{array}{l}\text { Baron and others (1963). } \\
\text { Shreiner and others (1967). }\end{array}$ \\
\hline
\end{tabular}

Some data on hydraulic conductivity and transmissivity of fractures in bedded anhydrite are available in the literature (table 4.1) and are described next.

Injection tests in a 62-m-deep well in New Mexico showed that gypsum, anhydrite, sandy clay, and breccia in the Castile Formation have a low transmissivity (Meinzer and others, 1927), as indicated by a low rate of injection of water $(1.3 \mathrm{~L} / \mathrm{min}$ (liters per minute)) in the bottom $25 \mathrm{~m}$ of the hole.

Some wells have tapped brine and gas in anhydrite of the Castile Formation at depths between 526 and 823 $\mathrm{m}$. These wells include several oil wells (Cooper, 1962; Lambert and Mercer, 1977; Powers and others, 1978) and one test well, ERDA No. 6. In two oil wells, the flow of brine decreased over a 1- to 2-day flow period, which suggests that the brine is contained in a pocket or fractures or in solution cavities nearby. The brine in the ERDA No. 6 well is between 570,000 and $1,000,000$ years old, but the connection to the underlying aquifer of the Delaware Mountain Group is unknown (Powers and others, 1978). The concentration of deuterium and oxygen-18 isotopes in brine in the ERDA No. 6 well indicate that the brine is not from a meteoric source or from evaporation of meteoric water or sea water; the composition of the brine probably is related to exchange between clay in the rock and water (Lambert, 1978).

In drill-stem tests of two other test wells, ERDA No. 8 and ERDA No. 9, in anhydrite of the Castile Formation, the anhydrite did not yield water from fractures (Lambert and Mercer, 1977; Powers and others, 1978).

Two wells were drilled in gypsum and salt in the Holston Valley in Virginia; one well was dry, but brine was found at $59 \mathrm{~m}$ in one well (Eckel, 1903).

Ground water has flowed from isolated reservoirs in fractured bedded anhydrite in mines in salt diapirs and salt deposits of the Zechstein Formation (Permian) in Germany (Baar, 1977). The initial outflow of brine was either a maximum flow under high gas pressure, or the outflow gradually reached a maximum flow. The flow gradually decreased to a low flow rate during a period ranging from days to more than 10 years. The fractures apparently are poorly connected hydraulically as indicated by the decrease in flow rate with time. For example, a drill hole hit a fissured system in anhydrite at a depth of $578 \mathrm{~m}$. The initial outflow of brine was $4 \mathrm{~L} / \mathrm{min}$, but decreased to $0.5 \mathrm{~L} / \mathrm{min}$ in 3 days. This isolated reservoir had a small volume of brine. An adit in a potash mine hit a fractured dipping anhydrite bed at a depth of $794 \mathrm{~m}$. A flow of brine increased for 6 months to a maximum flow rate of $30 \mathrm{~L} / \mathrm{min}$, and then decreased gradually for 13 years to a low rate of $1 \mathrm{~L} / \mathrm{min}$. In another mine, the inital flow rate from a fractured bed of anhydrite was $20 \mathrm{~L} / \mathrm{min}$, but decreased to $5 \mathrm{~L} / \mathrm{min}$ after 2.5 years. Pressure grouting that was done in an attempt to stop the flow in this mine caused the flow rate to increase rather than to decrease. Anhydrite beds may be pulled apart by salt flowage during tectonic deformation causing possible increases in fracture porosity (Baar, 1977).

Ground water in many gypsum mines in New York, Iowa, Virginia, and Canada flowed either from fractures or from solution cavities in the gypsum (table 4.1). Records of water inflow are not available for many gypsum mines, perhaps because water inflows were too minor to report. During sinking of some shafts in gypsum mines, large inflows of water from overlying sedimentary rocks either impeded the work or caused abandonment of the mine (table 4.1).

Some data are available on the occurrence of ground water in anhydrite in tunnels that have been driven through anhydrite rocks in France and Switzerland. Anhydrite and gypsum in the waterdiversion tunnel at Saint-Jean-de-Maurienne, France were completely dry because they underlie an impervious cover of Lias shale (table 4.1; Gignoux and Barbier, 1955). Anhydrite in the water-diversion tunnel of the 
factory near La Courbaisse, France, was dense and completely dry for a distance of $750 \mathrm{~m}$, but gypsum was found in a pulverized chaotic zone that had inflows of water in the roof (table 4.1; Gignoux and Barbier, 1955). Anhydrite, in the water-diversion tunnel near Tignes, France, appeared dry and dense and without visible open fractures, but it contained many veins of gypsum that sealed out water, thus preventing abundant water in the surrounding fractured shales from flowing through the anhydrite (table 4.1; Sahores, 1962). Hydration of anhydrite to gypsum in the Hauenstein and the Kappelisberg tunnels may or may not have caused expansion of the tunnel floor (Bendel, 1948). Rock bursts of anhydrite in the water-diversion tunnel of the factory near La Courbaisse, France, have been attributed to the expansion of anhydrite after hydration to gypsum (table 4.1; Gignoux and Barbier, 1955). However, in some tunnels and mines in France, the anhydrite heaves due to deformation pressures, and little expansion due to hydration to gypsum occurs; an exception is the railway tunnel near Le Braus, France, where raised slabs of gypsum occur on the walls.

The preceding observations indicate that bedded anhydrite may yield either minor amounts of water or no flowing water from fractures; therefore, the hydraulic conductivity and transmissivity of bedded anhydrite through fractures are low to extremely low. Because measurements of actual flows of water are not available, no estimates of values of hydraulic conductivity or transmissivity can be made.

The presence of gypsum or anhydrite in fractures indicates that water has flowed through or is flowing through anhydrite. In such places, ground water is likely to flow again or to continue to flow. For example, if fractures that are filled with gypsum are opened again by earth movements, then water probably will flow again from the fractures until they are resealed by gypsum. In the unsaturated zone of downward ground-water movement, hydration of anhydrite to gypsum probably takes place along fractures; the fractures are first widened by solution, and then anhydrite between the fractures is altered to gypsum (Lotze, 1957; Olive, 1957).

Anhydrite either may be deformed plastically with no apparent fractures or may be fractured or faulted (Lotze, 1957; Laubscher, 1975). Basement faults in the Gulf Coastal Plain terminate in the ductile anhydrite in the Buckner Formation. The Buckner anhydrite may have flowed significantly during Early Cretaceous time, as indicated by the disappearance of a conjugate pair of small faults in anhydrite in the Cretaceous Glen Rose Formation in the Blackfoot Field, Anderson County, Tex. (Fowler, 1964).

Gypsum veins may have originated within anhydrite and other rocks due either to mechanical force of crystallization or to high-pressured water that pushed apart the rock. Hypothetically, in high-pressured water, as the rocks are exhumed by erosion the lithostatic rock pressure lessens, but the fluid pressure is available to fracture the rocks by the hydraulic injection of water (Shearman and others, 1972).

\section{Hydraulic Characteristics of Anhydrite in Cap Rock of Salt Domes}

Anhydrite occurs in the cap rocks of salt domes where it is concentrated when solution of the upper part of the salt leaves grains of insoluble anhydrite that had been disseminated in the salt (Hoy and others, 1962; Bodenlos, 1970). Gypsum and limestone usually overlie the anhydrite; the gypsum is the result of the hydration of anhydrite by ground water, and the limestone overlying the gypsum is formed as a byproduct of bacterial sulfate reduction. The anhydrite in the cap rock is different from the laminated and nodular anhydrite in bedded-anhydrite deposits. The cap rock has a gneissic texture that is cut by many horizontal, vertical, and diagonal fractures. Most anhydrite along these fractures is hydrated to gypsum. In addition, the production of native sulfur throughout the cap rock has in places created porosity due to dissolution of anhydrite.

\section{Intercrystalline porosity in cap rock of salt domes}

The porosity of anhydrite in the cap rock is low compared with the porosity of the gypsum and limestone cap rocks that are above the anhydrite (Marx, 1936). The gypsum and limestone are porous and cavernous, and, in places, caverns or anhydrite sand are found at the contact of the anhydrite with the salt below (Judson and Stamey, 1933; O'Donnell, 1935; Taylor, 1937). Reported measurements of intercrystalline porosity in cap rock are not available, but, where the anhydrite is dense and does not contain sulfur or gypsum, the intercrystalline porosity is probably low. Any gypsum that is present may or may not increase the porosity of the anhydrite.

The intercrystalline porosity of some anhydrite in the cap rock is increased by widening of the cleavage in anhydrite crystals; the result is called emphasized cleavage (Goldman, 1952). Emphasized cleavage may form early in the deformation of anhydrite before stress becomes strong enough to produce fractures.

\section{Fracture porosity in cap rock of salt domes}

Reported measurements of fracture porosity or of fracture transmissivity in anhydrite of cap rock are not 
available. The numerous fractures in the anhydrite, however, suggest that the values of fracture porosity and fracture transmissivity probably are much greater than those in bedded anhydrite. Faults in anhydrite cap rock may be filled by porous anhydrite sand (O'Donnell, 1935).

Gypsum at a depth of $60 \mathrm{~m}$ below the surface in a mine in the cap rock of the Hockley salt dome is nearly watertight and contains only minor water seeps (Stenzel, 1943). These seeps may come either from fractures or from solution openings in the gypsum.

Stalactites in the roof and salt bubbles on the floor of the Carey salt mine, which is about $90 \mathrm{~m}$ below the anhydrite cap rock in the Winnfield salt dome, probably were created by drips from brine from inclusions in the salt or brine in fractures in the salt under the anhydrite cap rock (Hoy and others, 1962).

\section{GENERAL HYDROGEOLOGY OF ANHYDRITE}

Many general factors determine the hydrogeology of a particular anhydrite bed. These include the type of ground-water basin; the distribution, movement, and discharge of water in the basin; the position of the water table; the presence of water in the unsaturated zone and sinkholes above the water table; the presence of artesian aquifers or confining beds above, below, or lateral to the anhydrite bed; and chemical and microbiological reactions that take place in anhydrite.

The type of ground-water basin controls the distribution, movement, and discharge of ground water in artesian aquifers, fractures, and solution openings near or in anhydrite. At least three different types of artesian ground-water basins that contain anhydrite are known: (1) basins in which the flow of artesian water is from one side of the basin to the other; (2) basins in which the flow of artesian water is from both sides of the basin toward the center of the basin; (3) basins in which the flow of artesian water is from the center of the basin toward the sides of the basin (Drescher, 1965). The first type of basin is represented by the Delaware and Paradox basins; the second is represented by intermontane basins of the Southwest; and the third is represented by the Michigan basin. Movement of ground water in most basins is complex. Water may move along bedding or vertically across bedding through fractures, interstices, or semipermeable membranes of shale beds. Water may be discharged through springs or through underflow to another basin. In some basins, the presence of chlorideor sulfate-rich waters in springs or wells indicate that salt, anhydrite, or gypsum is being dissolved.

Fracturing of anhydrite or dissolution of anhydrite by thermal waters may be related to igneous activity or structural deformation during the hydrogeological history of a ground-water basin. The association of extrusive and intrusive igneous rocks with evaporite rocks and with the faulted basement that underlies evaporite rocks has been reported by many geologists (Hoen, 1964; Tazieff, 1970; Wilson, 1975). Diapirs are common in evaporite deposits, especially in structurally deformed rocks (Hoen, 1964; Henry and Zolnai, 1971).

The positions of the water table or potentiometric surface determine the possibility for forming caverns or sinkholes. Descending water in the unsaturated zone or ascending artesian flow of water through anhydrite may cause solution. Solution and collapse features may also occur where fractures connect pressurized freshwater aquifers and evaporites, or where evaporites are in contact laterally with freshwater aquifers. Mechanisms for lateral and vertical dissolution of evaporites linked hydraulically with undersaturated aquifers and recognition of features created by these mechanisms have been described by Anderson (1978), Anderson and others (1978), and Anderson and Kirkland (1980).

Artesian aquifers or confining beds may occur above, below, or lateral to anhydrite beds. Anhydrite beds commonly are overlain either by carbonate rocks that may be artesian aquifers or by salt beds that may be impermeable. Krumbein (1951) has described anhydrite deposits that are bounded above or below by either red beds or marine beds. Aquifers near evaporite deposits described by Johnson and Gonzales (1978), and artesian aquifers near salt domes that have anhydrite cap rocks were described by Anderson and others (1973).

Several chemical and bacterial reactions can alter anhydrite to gypsum, calcite, and (or) sulfur. Native sulfur occurs in gypsum, anhydrite, limestone, and dolomite of the cap rock overlying salt domes in the Gulf coastal plain (Ellison, 1971). Bacteria that live on hydrocarbons reduce the sulfate from gypsum and anhydrite to hydrogen sulfide, which then is reoxidized to native sulfur, possibly by reaction with sulfate (Feely and Kulp, 1957), but more likely by reaction with elemental oxygen (Davis and Kirkland, 1970; Kirkland and Evans, 1976). In this same reaction calcite is formed, as in the following reaction (Davis and Kirkland, 1970): $\mathrm{CaS}_{5}+\mathrm{CO}_{2}+\mathrm{H}_{2} \mathrm{O}--->4 \mathrm{~S}+\mathrm{CaCO}_{3}+\mathrm{H}_{2} \mathrm{~S}$. Limestone buttes or castiles are large, vertical pipelike masses of calcite that have replaced gypsum and anhydrite in the Castile Formation in the Delaware basin of New Mexico and Texas. The castiles probably were formed by sulfatereducing bacteria that subsisted on hydrocarbons in artesian ground water that rose along fractures (Davis and Kirkland, 1970). The calcite in the castiles has some porosity; therefore, large castiles form the reservoir rock for several shallow oil fields in the Castile Formation (West Texas Geological Society, 1960). 


\section{DISSOLUTION OF ANHYDRITE AND INTERBEDDED SALT}

Dissolution either of anhydrite or of salt that is interbedded in anhydrite may form channels for groundwater movement. Beds of dissolution breccia have been identified as fossil pathways for ground-water movement (Landes, 1959; Anderson and others, 1972; Anderson and Kirkland, 1980). Breccias in the Castile Formation, described in the reports by Anderson and colleagues, are composed of fragments of anhydrite that were left along bedding planes after salt beds were dissolved from beneath the anhydrite beds. Where these openings collapsed, vertical breccias or vertical breccia pipes formed in the anhydrite. Hypothetically, vertical pathways were formed either from artesian ground-water from the underlying Delaware Mountain Group aquifer or from water in the unsaturated zone working down from the surface. Castile Spring and Stinking Spring on the outcrop of the Castile Formation may be derived from artesian water of the Delaware Mountain aquifer (Davis and Kirkland, 1970).

The maximum depths at which solution of salt or anhydrite has been found typically range from 150 to $550 \mathrm{~m}$ (Frye and Schoff, 1942; Newland, 1929; Landes and others, 1945; and Anderson and others, 1972). Earlier occurrence of thermal water within any of the basins that contain evaporites probably would have accelerated deep solution of the salt and anhydrite. In general, because of the common, close association of thermal water with volcanic rocks, thermal water may have existed wherever volcanic rocks formed in a basin.

Observations of dissolution of anhydrite in outcrops, mines, tunnels, or springs are rare. However, many reports in the literature mention dissolution of both gypsum and anhydrite as a group.

Laboratory experiments on the solution of gypsum and anhydrite in both distilled water and salt water at $23{ }^{\circ} \mathrm{C}$ are described by James and Lupton (1978). These experiments show that the solution rate of gypsum in flowing distilled water is linear according to the differential rate equation $-d c / d t=k c$, but the solution rate of anhydrite is proportional to the square of the subsaturation concentration of calcium sulfate on the right side of a second-order differential rate equation $-d c / d t=k c^{2}$. The specific rate of dissolution of anhydrite - the constant, $k$, on the right side of the differential rate equation-increases linearly as water velocity increases from $0.02 \mathrm{~m} / \mathrm{s}$ (meter per second) to $0.75 \mathrm{~m} / \mathrm{s}$. These experiments were used by James and Lupton (1978) to predict runaway solution of anhydrite at low temperature and high water velocity. However, at and above temperatures of $40^{\circ} \mathrm{C}, k$ may become low because the solubility of anhydrite decreases as temperature increases. Nevertheless, the second-order kinetic equation for the dissolution of anhydrite should be considered seriously to avoid accelerating the dissolution of anhydrite.

\section{HYDRATION OF ANHYDRITE TO GYPSUM}

Hydration of anhydrite to gypsum may be caused by circulating ground water. Thus, the presence of gypsum is commonly an indicator of past or present ground-water movement through anhydrite. In some places, dissolution of anhydrite has formed karst, large underground channels, or sinkholes that may provide channels for more dissolution of anhydrite.

Hydration of anhydrite to gypsum may occur where anhydrite contacts an aquifer or where anhydrite contains a fault, a fracture, or a permeable interbed that is a conduit for ground water (Holliday, 1970). On a microscopic scale, cleavages within the individual anhydrite crystals become important channels for hydration (Deer and others, 1962). An example of hydration of anhydrite to gypsum near an aquifer occurs in rocks of Late Jurassic Purbeckian Age in England where the deepest anhydrite bed adjacent to an aquifer is completely hydrated to gypsum, whereas shallower anhydrite beds have been only partly hydrated (Howitt, 1964). Examples of hydration of anhydrite to gypsum along cross fractures and bedding planes occur in the anhydrite of the Blaine Formation in Oklahoma (Muir, 1934) and in an anhydrite formation in Italy (Lori and Frosio, 1962). Water seeping through sandy interbeds has hydrated the anhydrite to gypsum in part of the waterdiversion tunnel at La Léchère, France, (Sahores, 1962). If subject to continued dissolution, the gypsum itself may become a conduit for ground water, as illustrated by the brecciated, soft, porous, sugary gypsum along solution channels adjacent to anhydrite in the Medicine Lodge Gypsum Member of the Blaine Formation, Kans. (Kulstad and others, 1956). Hence, anhydrite that contains gypsum may have a greater hydraulic conductivity than does unaltered anhydrite.

Hydration of anhydrite produces two types of gypsum; namely, porphyroblastic secondary gypsum and alabastrine secondary gypsum. The porphyroblastic secondary gypsum consists of scattered, rather large porphyroblasts of gypsum crystals that contain many corroded relicts of anhydrite (Holliday, 1970). Porphyroblasts are early diagenetic minerals in some anhydrite beds, but they are related to the circulation of more recent ground water in other anhydrite beds (Holliday, 1970). Alabastrine secondary gypsum is very fine grained, nonporphyroblastic gypsum. Water amounts range from 0.01 to 0.69 percent in the chemical analyses of four of six anhydrite samples reported by Deer and others (1962). 
Large-scale alteration of anhydrite to large masses of gypsum that may contain karst caverns or sinkholes has been observed on outcrops of anhydrite (Hensler, 1968). In an outcrop, an anhydrite bed may be hydrated at the top, side, bottom, or interior of the bed (Bailey and Fredericton, 1931). Karst in gypsum has been found in many outcrops of anhydrite, and in some areas the solution of salt occurs in the same evaporite section as gypsum (Gould, 1905; Landes and others, 1945). In New Mexico, the flow of the Pecos River goes into solution channels in the gypsiferous Seven Rivers Formation beneath McMillan reservoir and emerges $5 \mathrm{~km}$ to the south in Major Johnson Springs (Reeder and Thatcher, 1963).

The depth of hydration of anhydrite is commonly 90-150 $\mathrm{m}$ below the surface. Gypsum has been found at a depth of more than $1,000 \mathrm{~m}$ in the San Andres Limestone of Permian age in Texas (Murray, 1964), but gypsum rarely is found below a depth of $610 \mathrm{~m}$ (West, 1964) because, below this depth, the temperature generally is higher than $42^{\circ} \mathrm{C}$ and anhydrite is the stable mineral above $42^{\circ} \mathrm{C}$ (Murray, 1964).

Hydration of anhydrite to gypsum may cause the rock to expand, as shown by increases in thickness of beds after alteration (Newland, 1929; Anderson and Kirkland, 1966; Hite, 1977) or by large bulging shells or spalling in quarries, tunnels, and outcrops, sometimes with violent explosions (Allen, 1971; Gignoux and Barbier, 1955; Sahores, 1962; Brune, 1965; Beales and Oldershaw, 1969). This expansion after hydration may result in an increase in hydraulic fracture conductivity. However, other investigators have not found evidence for expansion on hydration of anhydrite to gypsum (Kulstad and others, 1956; Sahores, 1962; and Holliday, 1970). The amount of expansion may be determined by the amount of flow through the rock carrying sulfate away, the degree of saturation of the water with respect to anhydrite, the amount of confinement of the anhydrite, and the salinity and composition of the water.

\section{DATA FROM SPRINGS}

Data on springs that flow from anhydrite or gypsum are presented in table 4.1. Some of the water in these springs is actively dissolving anhydrite or gypsum, as indicated by saturation values of calcium and sulfate. Some springs appear to have artesian water that passes through anhydrite or gypsum.

\section{SUMMARY AND CONCLUSIONS}

Data on the hydrogeology of anhydrite are sparse and scattered in the literature. Anhydrite is apparently a confining bed if it does not have fractures, permeable interbeds, dissolution, or hydration to gypsum.

Bedded anhydrite apparently has a low mean value of intercrystalline porosity (about 1 percent). However, bedded gypsum has mean values of intercrystalline porosity that may be either low (about 1 percent), or much higher (about 20 percent), depending perhaps on how much gypsum had been dissolved and carried away. The intercrystalline hydraulic conductivity of anhydrite apparently is zero or near zero; the fracture porosity and fracture transmissivity of bedded anhydrite are inferred to range from zero to low. Fractures may be rare or absent in bedded anhydrite, and in many oil fields bedded anhydrite forms an impervious seal. In addition, fractured reservoirs in bedded anhydrite appear to be isolated reservoirs in which fractures are poorly connected.

The anhydrite in the cap rock of salt domes probably has a low intercrystalline porosity. However, the fracture transmissivity in places is probably much greater than that in bedded anhydrite, because the cap rock has been highly fractured and because dissolution or hydration to gypsum has probably increased the fracture transmissivity in the cap rock.

Many other factors affect the hydrogeology of anhydrite. Dissolution of either anhydrite or interbedded salt may form channels for ground-water movement. Hydration of anhydrite to gypsum may increase the intercrystalline or fracture openings by replacing anhydrite with gypsum, which may be more transmissive to ground water than is anhydrite. General factors that affect the hydrogeology of anhydrite include type of ground-water basin, movement and discharge of ground water in the basin, position of the water table, presence of water and sinkholes in the unsaturated zone, artesian aquifers or confining beds near anhydrite, and chemical and bacterial reactions that take place in anhydrite. 



\title{
SECTION 5. Chemical Properties of Anhydrite
}

\author{
By ROBERT W. POTTER II and MICHAEL A. CLYNNE
}

\section{INTRODUCTION}

Several geochemical criteria must be met in considering anhydrite as a radioactive waste-repository medium (Committee on Radioactive Waste Management, 1978):

1. Radioactive heat and radiation should not reach levels high enough to produce physical and chemical reactions in the repository rock that would compromise geological containment.

2. Interaction of water, repository rock, and waste material should be controlled to minimize the rate of dissolution of the waste form.

3. Water in the repository, if present, should not react chemically or physically with the repository rock to increase its permeability, which would compromise geological containment.

4. The properties of the geochemical system of the radionuclides, the repository rock, and its associated water should restrict or prevent the mobility of the radionuclides and should delay or prevent their migration to the biosphere.

The United States, as part of the International Nuclear-Fuel Cycle Evaluation (INFCE) Program, has agreed to certain thermal-loading criteria for salt repositories. These criteria (Arbital and others, 1979) may be summarized in three categories:

Very-near-field:

Maximum high-level waste (HLW) temperature shall be $500^{\circ} \mathrm{C}$. Maximum spent-fuel pin temperature shall be $200{ }^{\circ} \mathrm{C}$.

Less than 1 percent of the rock adjacent to the canister shall be allowed to exceed $200^{\circ} \mathrm{C}$.

Near-field:

Less than 25 percent of the rock at the canister horizon shall be allowed to exceed $200^{\circ} \mathrm{C}$.

Far-field:

Maximum surficial displacement due to thermal expansion and room closure shall be $1.5 \mathrm{~m}$.

The chemical properties of anhydrite that were the first indications that it could be used as a potential waste-repository medium are its low solubility relative to halite and the retrograde nature of its solubility; that is, the solubility decreases as temperature increases. Because of retrograde solubility, migration of fluid inclusions in anhydrite would be away from the heat source, rather than toward it as with halite. Anhydrite also appears to have a higher sorptive capacity for radionuclides than halite, occurs in favorable geologic environments, and has a thermal conductivity as high as that of halite.

This section of the present report summarizes the data now available from the literature for the chemical properties of anhydrite and related phases of calcium sulfate, and indicates how the data relate to the suitability of anhydrite as a waste-repository medium. In particular, we examine the current knowledge of the phase equilibria, crystallography, thermochemistry, and kinetics of reaction for calcium sulfate; the sorptive capacity of anhydrite for radionuclides; and effects of radiation on anhydrite and related phases.

The reported phases in the system $\mathrm{CaSO}_{4}-\mathrm{H}_{2} \mathrm{O}$, which are relevant to the use of anhydrite as a wasterepository medium, are listed in table 5.1. The references cited are those considered to be most relevant to evaluating anhydrite as a repository host rock and were selected from more than 500 references.

\section{THERMOCHEMISTRY OF ANHYDRITE AND RELATED PHASES}

The thermochemical properties of anhydrite have been thoroughly evaluated by Parker and others (1971) and by Robie and others (1978). As a result of these and other investigations, the data for the thermochemical properties of anhydrite are known over its entire stability range. The data are sufficiently accurate for the appraisal of anhydrite as a waste-repository medium. The thermochemical properties of gypsum also are summarized in 
Table 5.1 Phases in the system $\mathrm{CaSO}_{4}-\mathrm{H}_{2} \mathrm{O}$.

[Note: Dehydration reactions appear to progress from gypsum to bassanite to soluble anhydrite to anhydrite; hydration reactions progress from anhydrite to bassanite to gypsum]

\begin{tabular}{|c|c|c|}
\hline Composition & Mineral or phase name & Remarks \\
\hline $\mathrm{CaSO}_{4} \cdot 2 \mathrm{H}_{2} \mathrm{O}-\cdots$ & Gyps um-_- & Stable phase. \\
\hline $\mathrm{CaSO}_{4} \cdot 0.5 \mathrm{H}_{2} \mathrm{O}^{---}$ & Bassanite (hemihydrite)- & Metastable phase. \\
\hline $\mathrm{CaSO}_{4} \cdot \mathrm{nH}_{2} \mathrm{O}-\cdots$ & "Soluble anhydrite"----- & $\begin{array}{l}\text { Metastable phases; } \mathrm{n} \\
\text { (water of hydration) } \\
\text { varies from } 0 \text { to } 1 \text {; } \\
\text { serious questions as to } \\
\text { whether the phase is } \\
\text { distinct from bassanite. }\end{array}$ \\
\hline $\mathrm{CaSO}_{4}-\cdots$ & Anhydrite-- & Stable. \\
\hline
\end{tabular}

the two reports cited and appear to be known sufficiently. Thermochemical data for phases of calcium sulfate are summarized in table 5.2.

Thermochemical data for the two compounds of calcium sulfate intermediate in hydration between anhydrite and gypsum have been evaluated by Naumov and others (1971). They list thermochemical properties for $25^{\circ} \mathrm{C}$, and additional heat-capacity equations for temperatures to approximately $100{ }^{\circ} \mathrm{C}$. In the tabulation by Naumov and others (1971), both bassanite and "soluble anhydrite" are indicated as having one-half water of hydration. These authors gave the difference in free energy between bassanite and "soluble anhydrite" at $25^{\circ} \mathrm{C}$ as about 200 cal (calories), but many crystallographic studies indicate that no structural differences exist between bassanite and "soluble anhydrite" that contain as much as one water of hydration. The starting materials used by Naumov and others (1971) to determine the thermochemical properties were precipitates produced by specific chemical procedures (Farnsworth,
1924; Kelley and others, 1941) rather than wellcharacterized equilibrium phases. Thus, the materials could have been kinetically controlled metastable precipitates. Naumov and others (1971) also suggested that some of the prepared materials were amorphous, which probably accounts for the scatter in their data on solubility and composition. Because of the contradictory crystallographic data, the uncertainties in the thermochemical data, the highly variable solubility data, and the lack of well-characterized starting materials, the existence of two distinct phases is uncertain.

Data on thermochemical properties of the lower hydrates would be useful only in assessing the consequences of a flooded anhydrite repository after a thermal pulse if the reactions are equilibrium-controlled. Current evidence, however, suggests that the reactions are kinetically controlled. Hence, data on reaction kinetics would be more pertinent than would data on equilibrium thermochemistry. Further work on the thermochemistry

Table 5.2 Thermochemical properties of calcium sulfate phases

$\left[\Delta \mathrm{G}, \Delta \mathrm{H}, \mathrm{S}_{\mathrm{T}}\right.$, and $\mathrm{C}_{\mathrm{P}}$ are the standard free energy of formation, enthalpy, and entropy at constant temperature, and heat capacity at constant pressure, respectively. Water of hydration is the value of $n$ in the general formula $\mathrm{CaSO}_{4} \cdot n \mathrm{H}_{2} \mathrm{O} . \mathrm{KJ}_{\text {, }}$ kilojoules; $\mathbf{J}$, joules]

\begin{tabular}{lccccc}
\hline Phase & $\begin{array}{c}\text { Water of } \\
\text { hydration }\end{array}$ & $\begin{array}{c}\Delta G \\
(\mathrm{KJ} / \mathrm{mole})\end{array}$ & $\begin{array}{c}\Delta \mathrm{H} \\
(\mathrm{KJ} / \mathrm{mole})\end{array}$ & $\begin{array}{c}\mathrm{S}_{\mathrm{T}} \\
(\mathrm{J} / \mathrm{mole})\end{array}$ & $\begin{array}{c}\mathrm{C}_{\mathrm{p}} \\
(\mathrm{J} / \mathrm{mole})\end{array}$ \\
\hline Anhydrite----- & 0.0 & -1321.7 & -1434.1 & 106.69 & 99.66 \\
"Soluble anhydrite"-- & 0.5 & -1460.3 & -1574.5 & 134.31 & 124.22 \\
Bassanite---- & 0.5 & -1461.3 & -1576.6 & 130.54 & 119.41 \\
Gypsum---- & 2.0 & -1797.2 & -2022.6 & 194.14 & 186.02 \\
\hline
\end{tabular}




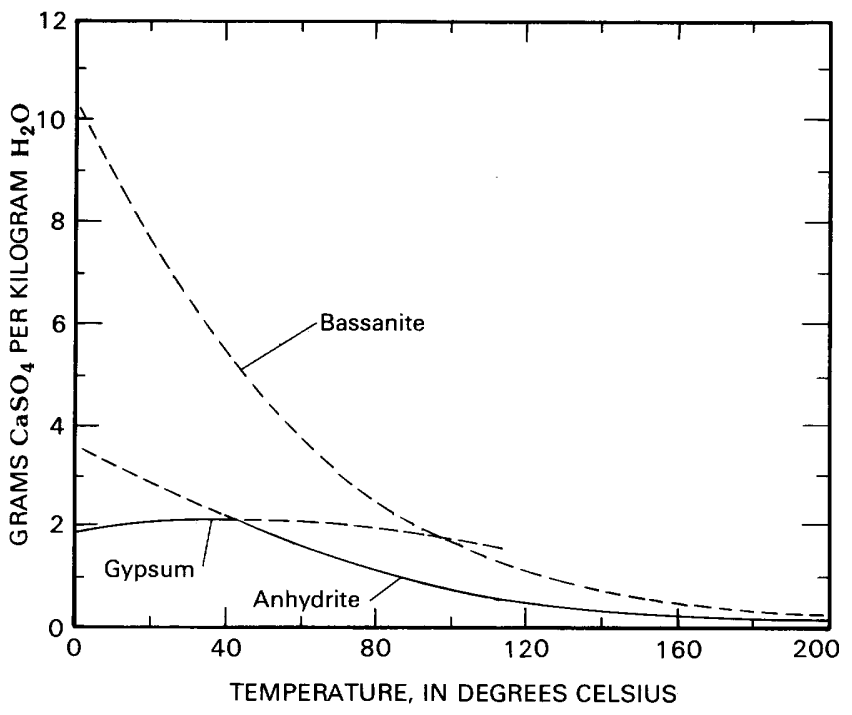

Figure 5.1 Solubility relationships of calcium sulfate minerals in pure water. Dashed lines represent metastable equilibria.

of phases of calcium sulfate should be deferred until adequate data on crystallography and appropriate kinetic paths of the lower hydrates are available.

\section{CRYSTALLOGRAPHY OF ANHYDRITE AND RELATED PHASES}

X-ray powder diffraction data for gypsum and anhydrite and the resulting crystallographic conclusions are moderately well known and understood. Recent crystal structure refinements for anhydrite (Morikawa and others, 1975) and gypsum (Cole and Lancucki, 1974) are available. Both of these references summarize data from older literature. Powder X-ray diffraction data for anhydrite have been evaluated by Swanson and others (1955) who compared their data for synthetic anhydrite with earlier data. Grattan-Bellew (1975) has made an exhaustive study of the X-ray powder diffraction characteristics of gypsum, including the effects of preferred orientation.

Crystallographic data for the lower hydrates of calcium sulfate are less well understood. Studies by Jung (1925), Ransdell and Partridge (1929), Bunn (1941), and Cano and Chatelain (1958) stated that no crystallographic differences exist between bassanite and "soluble anhydrite" from no water of hydration to as much as one water of hydration. Conversely, detailed studies by Florke (1952) and Gay (1965, 1965b), and Florke (1952) have shown that a variety of structures exist between bassanite and anhydrite. Gay (1965a,b) observed intergrowths of fibrous crystals of gypsum and lower hydrates, which may explain the variable water analyses. Further work on the problem should be approached using more modern methods, such as highresolution electron microscopy. Such studies should determine the various domains and intergrowths that are present and should provide the necessary characterization of starting materials and products required for kinetic studies.

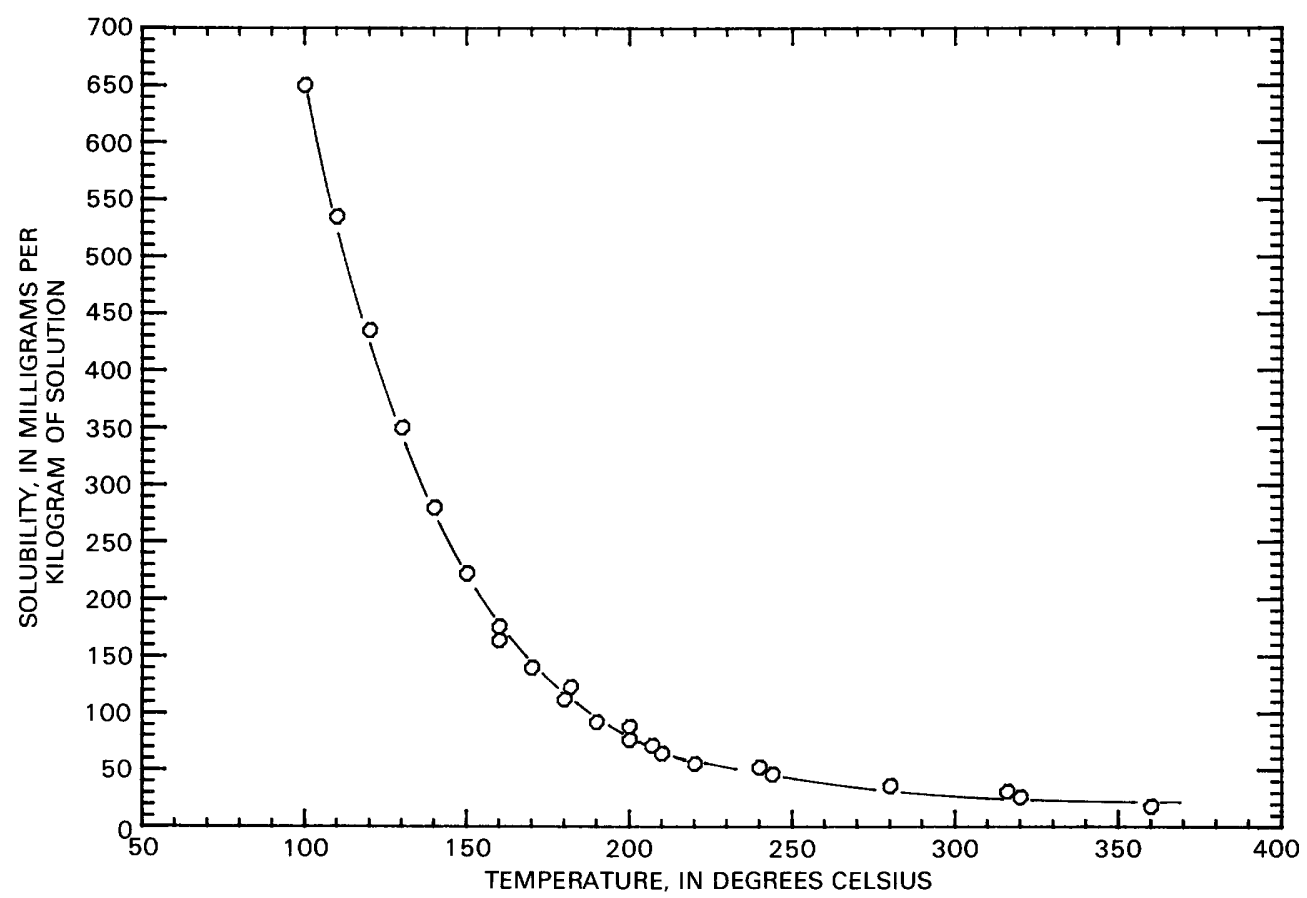

Figure 5.2 Solubility of anhydrite in pure water (data from Dickson and others, 1963; Booth and Bidwell, 1950; d'Ans and others, 1955; Ravich, 1974). 


\section{PHASE-EQUILIBRIA AND SOLUBILITY RELATIONSHIPS}

The properties of anhydrite that were the first indications that it could be used as a waste-repository medium are its solubility, which is relatively low compared with that of halite, and the retrograde nature of its solubility to temperatures as high as $200^{\circ}-250^{\circ} \mathrm{C}$. The stability of anhydrite in the presence of bitterns is important in assessing the behavior of a repository should it flood after a thermal period. Phase equilibria among anhydrite, brines, and common impurities such as carbonates and clays are significant in assessing the performance of a repository.

Anhydrite is the stable form of $\mathrm{CaSO}_{4}$ at all temperatures expected in a waste repository. The anhydrite structure is stable to about $1,150{ }^{\circ} \mathrm{C}$, at which point it undergoes a polymorphic transition (Gay, 1965b); it does not begin to decompose until $1,450^{\circ} \mathrm{C}$ is exceeded. Relevant phase-equilibria data for anhydrite and various salts have been summarized by Rowe and others (1972). In the dry systems that have been studied to date involving salts commonly found in evaporite deposits, none of the liquidus surfaces is lowered sufficiently to cause melting at the temperatures estimated for repositories. However, data are sparse for multicomponent phase equilibria in dry systems involving anhydrite.

The solubility of calcium sulfate in pure water is low (about $2.0 \mathrm{~g} / \mathrm{kg}$ (grams per kilogram) $\mathrm{H}_{2} \mathrm{O}$ at $20^{\circ} \mathrm{C}$ ) and retrograde (decreasing to about $25 \mathrm{mg} / \mathrm{kg}$ (milligrams per kilogram) $\mathrm{H}_{2} \mathrm{O}$ at $350{ }^{\circ} \mathrm{C}$ ) (figs. 5.1 and 5.2). Experimental evidence indicates that the solubility of anhydrite becomes prograde at temperatures in excess of the critical point of pure water (Booth and Bidwell, 1950; Morey and Hesselgesser, 1951). However, whether the critical surface is continuous, as it is for halite, is still unresolved (Keevil, 1942; Ravich, 1974). Solubility relationships become more difficult to resolve at lower temperatures, due to a strong tendency for metastability exhibited by calcium sulfate. Figure 5.1 is a synthesis of the published data for solubilities of calcium-sulfate minerals in pure water as a function of temperature as high as $200{ }^{\circ} \mathrm{C}$. Data on the solubility of the "soluble anhydrite" phase are unreliable and have been omitted from figure 5.1. Figure 5.2 shows anhydrite solubility in water as high as $360^{\circ} \mathrm{C}$.

The best value for the transition of gypsum to anhydrite in equilibrium with pure $\mathrm{H}_{2} \mathrm{O}$ at 1-bar pressure seems to be $45^{\circ} \pm 15^{\circ} \mathrm{C}$, although the published-literature values range from $33{ }^{\circ} \mathrm{C}$ to $107{ }^{\circ} \mathrm{C}$. The transition temperature, which is lower as salinity increases, is $20^{\circ} \pm 3{ }^{\circ} \mathrm{C}$ in solutions saturated with respect to halite (Hardie, 1965; 1967).

The data for pure water show that anhydrite maintains its retrograde solubility over the expected

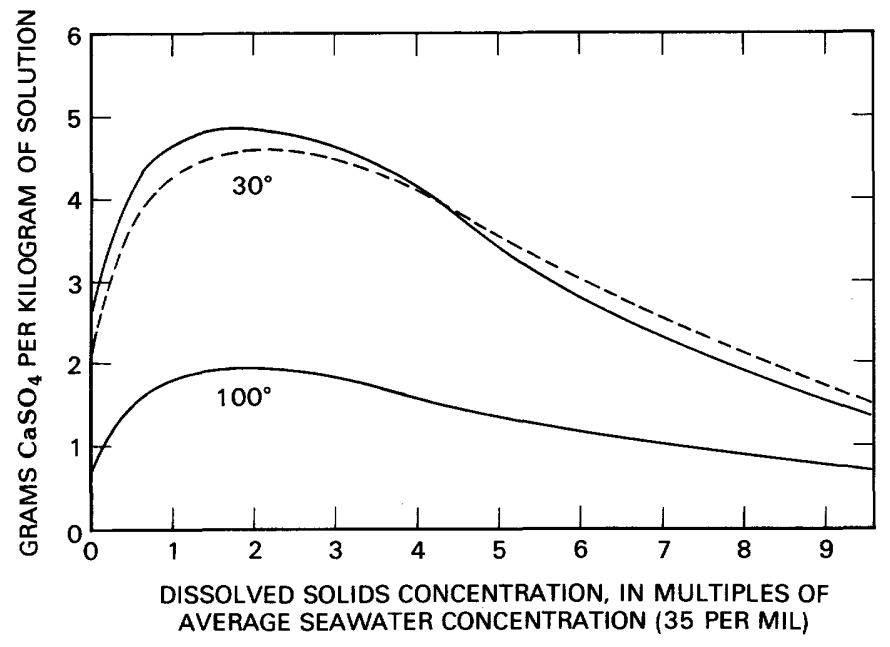

Figure 5.3 Solubility of gypsum (dashed line) and anhydrite (solid line) in seawater concentrates at constant temperature as a function of the amount of concentration of the seawater (data from Posnjak, 1940; and Hara and others, 1934).

temperature range in an operating waste repository. However, both pressure and high concentrations of complexing ions will significantly increase anhydrite solubility and consequently could alter the retrograde nature of the solubility curve. Figure 5.3 illustrates the effect of increasing ionic strength (the sum of the effective concentrations of all dissolved ions) expressed as multiples of seawater concentration (ionic strength of 0.75 ) at constant temperature for both gypsum and anhydrite. The solubility of $\mathrm{CaSO}_{4}$ increases rapidly as ionic strength increases, reaches a maximum, and then steadily declines as the ionic strength increases. The decline with increasing ionic strength illustrated in figure 5.3 is due to a strong, common-ion effect because seawater contains calcium and sulfate. Figure 5.4 illustrates an example of the absence of a strong common ion effect. In this diagram, the solubility of anhydrite as a function of sodium chloride content is plotted for $200{ }^{\circ} \mathrm{C}$. As in the common-ion effect, the solubility initially increases rapidly but then increases more slowly at high sodium chloride concentrations. This relationship implies that at high ionic strengths, hydrolysis reactions are occuring that limit the amount of calcium sulfate that can exist in solution.

Solubility studies of anhydrite in a halite-saturated solution as a function of temperature indicate that the solubility remains rather low and that the retrograde nature of the solubility is maintained to temperatures as high as $235^{\circ} \pm 10^{\circ} \mathrm{C}$ (fig. 5.5) (Clynne and Potter, 1979). Stewart and Potter (1979) pointed out that brines to be expected in an evaporite environment would be bitterns rather than simple, saturated sodium chloride brines. The solubility of anhydrite in bitterns is lower, and the 


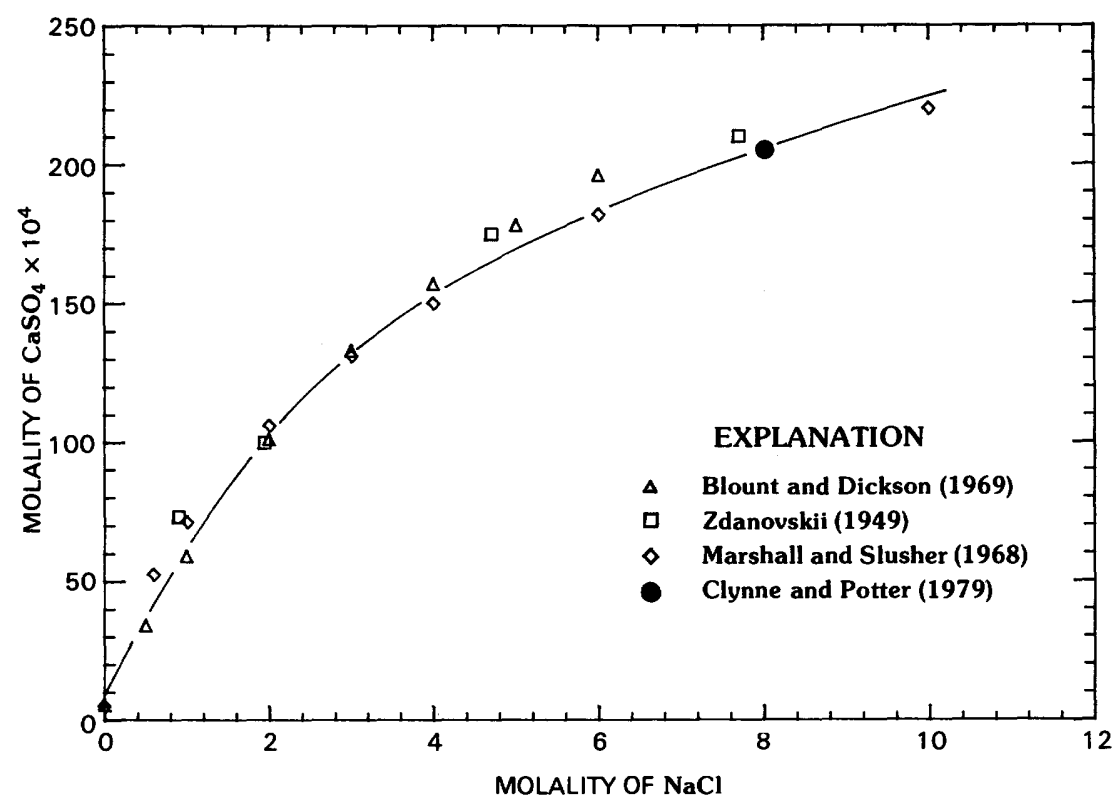

Figure 5.4 Solubility of anhydrite in sodium chloride solutions at $200^{\circ}$ Celsius as a function of the molality of sodium chloride.

change from retrograde to prograde solubilty occurs at higher temperatures (fig. 5.5) (Clynne and Potter, 1979) than in halite-saturated brines. This behavior can be attributed to higher ionic strength of bitterns and to strong common-ion effects due to the high calcium concentrations in bittern brines.

Marshall and Slusher (1968) show that in a saturated solution in equilibrium with $\mathrm{CaSO}_{4}, \mathrm{Ca}^{2+}$ and $\mathrm{SO}_{4}^{2-}$ become increasingly associated to the neutral species $\mathrm{CaSO}_{4}^{\circ}$ as temperature and ionic strength increase. Because $\mathrm{CaSO}_{4}$, is less soluble than $\mathrm{Ca}^{2+}$ plus $\mathrm{SO}_{4}^{2-}, \mathrm{CaSO}_{4}$ shows a decrease in solubility as temperature increases. At high temperatures, $\mathrm{CaSO}_{4}^{\circ}$ decomposes and other complex ions, such as $\mathrm{CaCl}^{+}$, $\mathrm{HSO}_{4}^{-}$and in more complex systems $\mathrm{NaHSO}_{4}^{\circ}$, become important (Bischoff and Seyfried, 1978). The interplay of these large ions and the looser structure of water at high temperatures cause the retrograde-to-prograde shift in anhydrite solubility to occur at different temperatures in different systems.

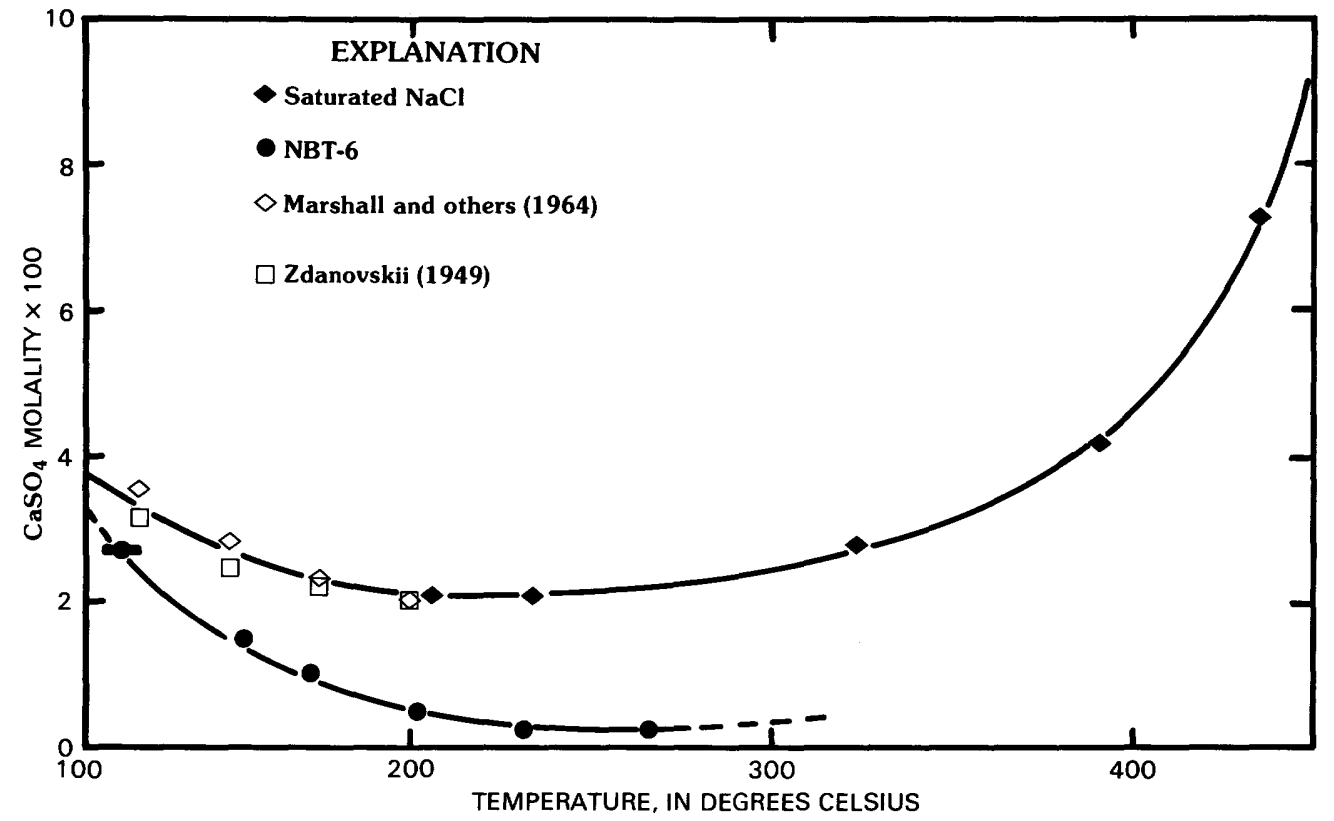

Figure 5.5 Solubility of anhydrite in equilibrium with solid sodium chloride and a representative bittern brine (NBT-6) as a function of temperature. NBT-6, natural bittern \#60. 


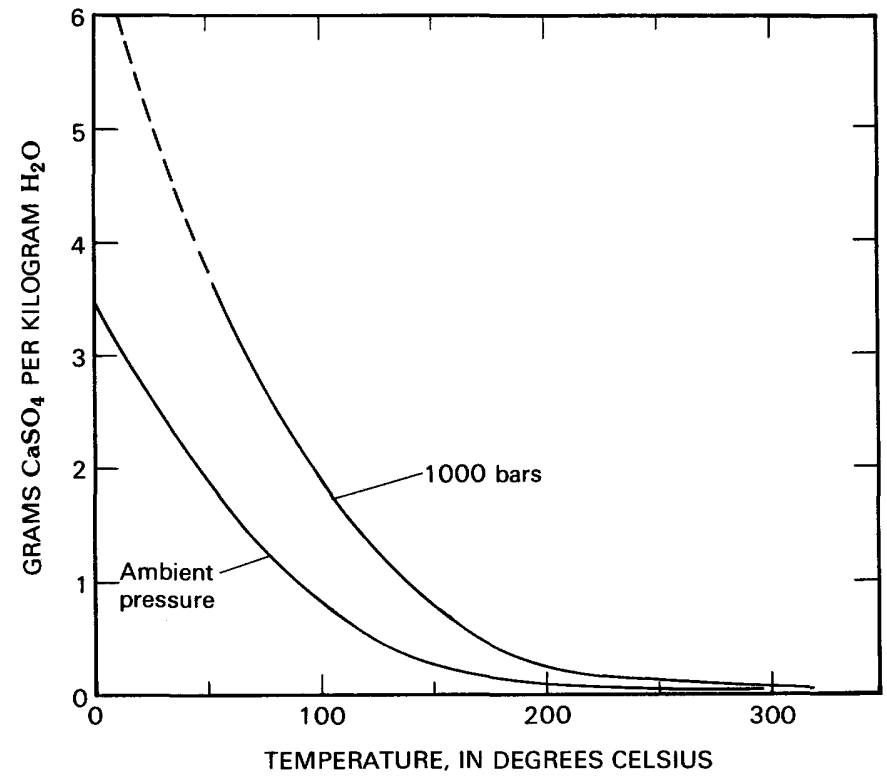

Figure 5.6 Effect of pressure on the solubility of anhydrite in pure water as a function of temperature (data from d'Ans and others, 1955). Solubility curve for 1,000 bars is dashed where extrapolated.

Confining pressure increases the solubility of anhydrite in pure water. Because the increase is greatest at temperatures less than $150{ }^{\circ} \mathrm{C}$ (fig. 5.6), increasing pressure extends retrograde solubility to higher temperatures. However, as the concentration of sodium chloride in solution is increased under a confining pressure of 1,000 bars, the transition from retrograde to prograde solubility is shifted towards lower temperatures (fig. 5.7) (Blount and Dickson, 1969; Dickson and others, 1963). For example, the solubility of anhydrite is continuously retrograde to as high as $300^{\circ} \mathrm{C}$ along the vapor-saturated surface for a 6-molal sodium chloride solution. The transition from retrograde to prograde for a 6-molal sodium chloride solution at a total pressure of 500 bars occurs at about $275{ }^{\circ} \mathrm{C}$, whereas at 1,000 bars the transition occurs at about $250{ }^{\circ} \mathrm{C}$. The change from retrograde to prograde solubility as a function of increased pressure and ionic strength in sodium chloride solutions is at temperatures and pressures that pose no difficulties for the use of anhydrite as a repository medium, but the effect may not be the same for natural brines. We cannot evaluate this possibility because no data for natural brines are available.

Another unresolved problem is the stability of anhydrite in bittern brines. Essentially, this involves phase equilibria in the system $\mathrm{Na}, \mathrm{K}, \mathrm{Mg}, \mathrm{Ca}, \mathrm{Cl}$, and $\mathrm{SO}_{4}$ at low temperatures. The current knowledge on this system has been summarized by Braitsch (1971) (figs. 5.8 and 5.9). These diagrams for $55^{\circ} \mathrm{C}$ (fig. 5.8) and $83{ }^{\circ} \mathrm{C}$ (fig. 5.9) show that the most likely alteration product of anhydrite is polyhalite, which would result in a volume

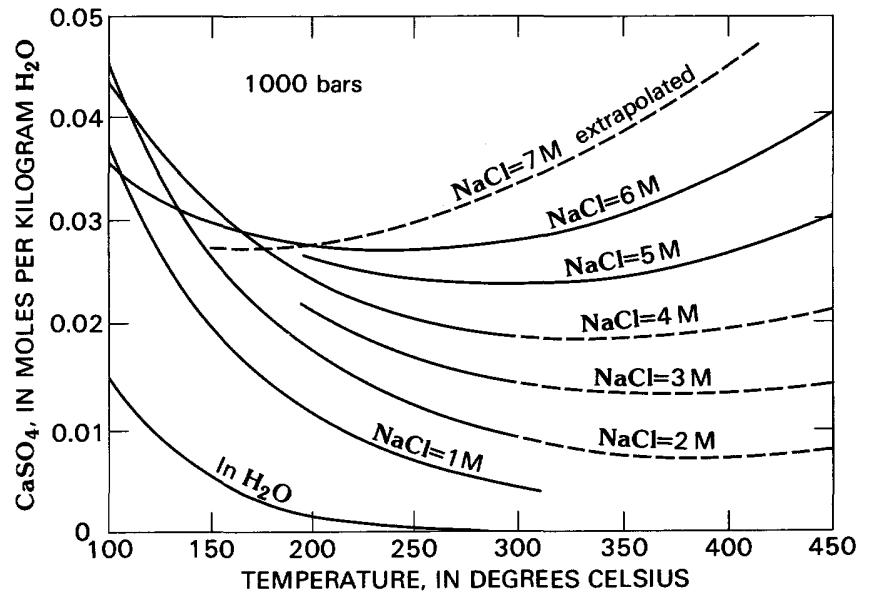

Figure 5.7 Solubility of anhydrite at 1,000 bars as a function of temperature and sodium chioride concentration (from Blount and Dickson, 1969). Solubility curves are dashed where extrapolated. M, molar. Reprinted with permission of Pergamon Press, Ltd.

expansion of about 7 percent. The rate at which this alteration proceeds is slow, comparable to that of the dehydration of gypsum. The equilibria at lower temperatures are not well established due to the extreme sluggishness of the reactions involved (Autenrieth, 1958; Braitsch, 1971). The most important data needed for the assessment of the degree of interaction of bittern brines and anhydrite are kinetic rates and the paths of the reactions. Both natural occurrences (Braitsch, 1971) and experimental data (for example Perova, 1970a,b) clearly show that the primary phases to form from bittern brines would be polyhalite, gypsum, and possibly one or more of the lower hydrates of calcium sulfate. Formation of these alteration products would remove water from the system, but significant volume expansion could cause the formation to fracture and enhance fluid mobility.

Phase equilibria in the system $\mathrm{Na}, \mathrm{K}, \mathrm{Mg}, \mathrm{Ca}, \mathrm{Cl}$, and $\mathrm{SO}_{4}$, plus carbonates and silicates, at elevated temperatures and pressures generally are unexplored although limited data are available for some simpler assemblages. Reaction rates at waste-repository temperatures should be fast enough that equilibrium data would be preferable to kinetic data for identifing stable assemblages. If these assemblages are different from those observed in natural systems, the reactions producing them are of interest. Most reactions should produce a less permeable rock, unless the volume changes are large enough to cause the formation to fracture.

\section{KINETICS OF REACTIONS INVOLVING ANHYDRITE}

Data on the kinetics of reactions pertinent to assessing anhydrite as a waste-repository medium are 


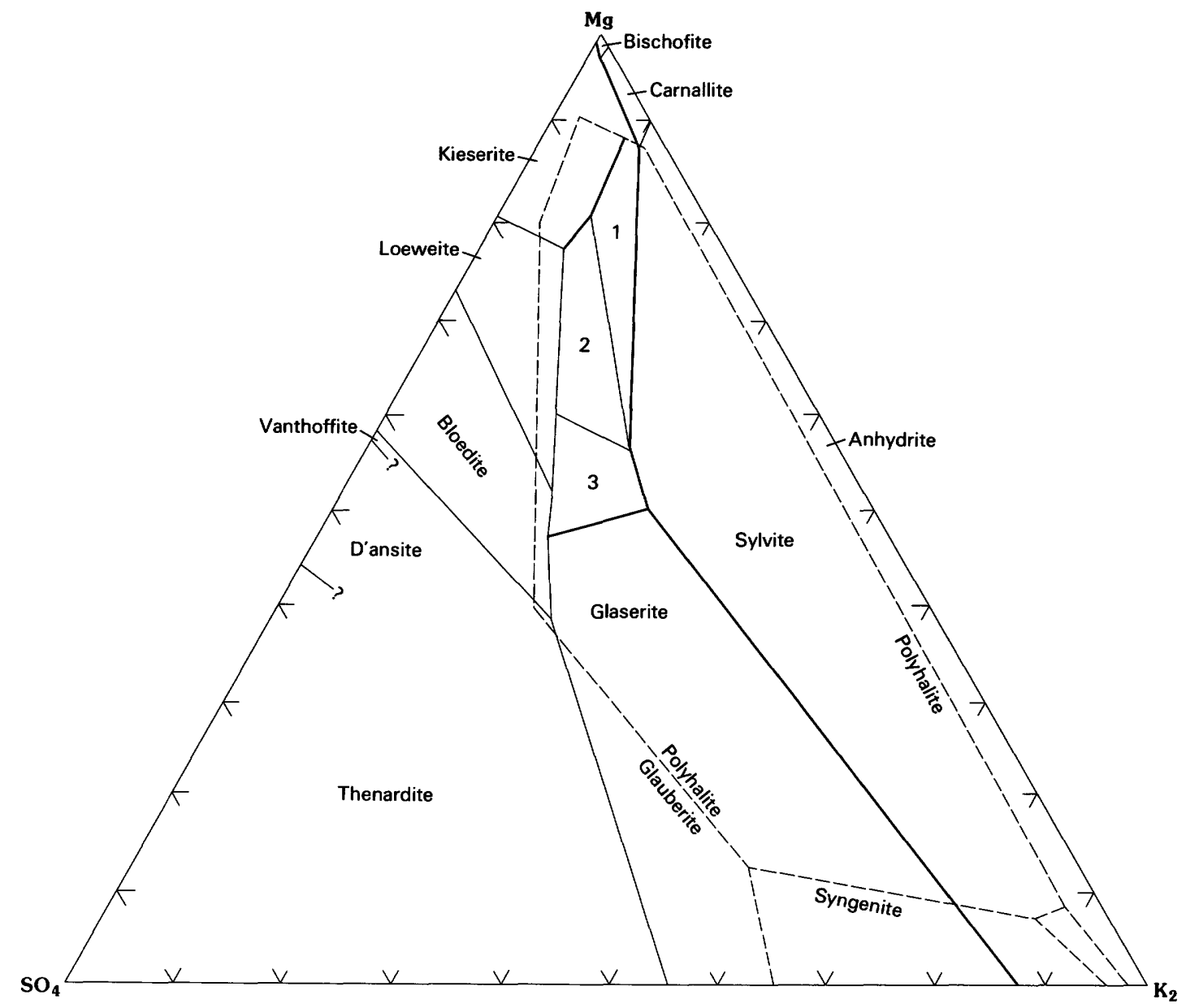

Figure $5.855^{\circ}$-isotherm of the five-component system $\mathrm{NaCl}-\mathrm{KCl}-\mathrm{MgCl}_{2}-\mathrm{Na}_{2} \mathrm{SO}_{4}-\mathrm{H}_{2} \mathrm{O}$ at sodium cloride saturation. Calcium-sulfate fields (dashed lines) approximated. Crystallization paths are heavy lines; transition lines, fine lines. 1, kainite; 2, langbeinite; and 3, leonite (modified from Braitsch, 1971).

scant. At temperatures as high as $200{ }^{\circ} \mathrm{C}$, the only available data are those on the solubility of gypsum and anhydrite in sodium chloride and seawater solution (Marshall and others, 1964; Marshall and Slusher, 1966, 1968). At temperatures lower than $110{ }^{\circ} \mathrm{C}$, several workers (Zen, 1965; Hardie, 1965) have recorded thermodynamic data as a function of time, which would permit extraction of kinetic data. In general, data for the kinetics of reactions in the pertinent systems are inadequate. Table 5.3 lists the reactions and temperature ranges for which data would be most useful.

\section{SORPTION OF RADIONUCLIDES BY ANHYDRITE}

Data for the sorption of radionuclides on anhydrite are meager, consisting of only two internal reports from the U.S. Department of Energy National Laboratories (Serne and others, 1977; Fried and others 1978). The tentative conclusion that can be drawn from these data is that anhydrite has a higher fixative capacity than does halite, and appears to have a greater fixative capacity than does volcanic tuff for certain radionuclides. Experiments on the fixative capacity for $\mathrm{TcO}_{4}$ and $\mathrm{IO}_{3}$ showed that tuff removed less than 1 percent of the ions from solution, whereas anhydrite stripped 4 percent of the $\mathrm{TcO}_{4}$ and 59 percent of the $\mathrm{IO}_{3}$ from solution. Although these results are promising, experimental data for a wider range of radionuclides is needed to allow quantitative estimates of the fixative capacity of anhydrite under realistic conditions.

\section{RADIATION EFFECTS ON THE CHEMISTRY OF ANHYDRITE}

No data on the effects of radiation on the chemistry of anhydrite could be found. The chemical and physical effects of radiation are expected to be minor, although radiation-induced distortion of the crystal lattices of minerals generally increases their solubility and 


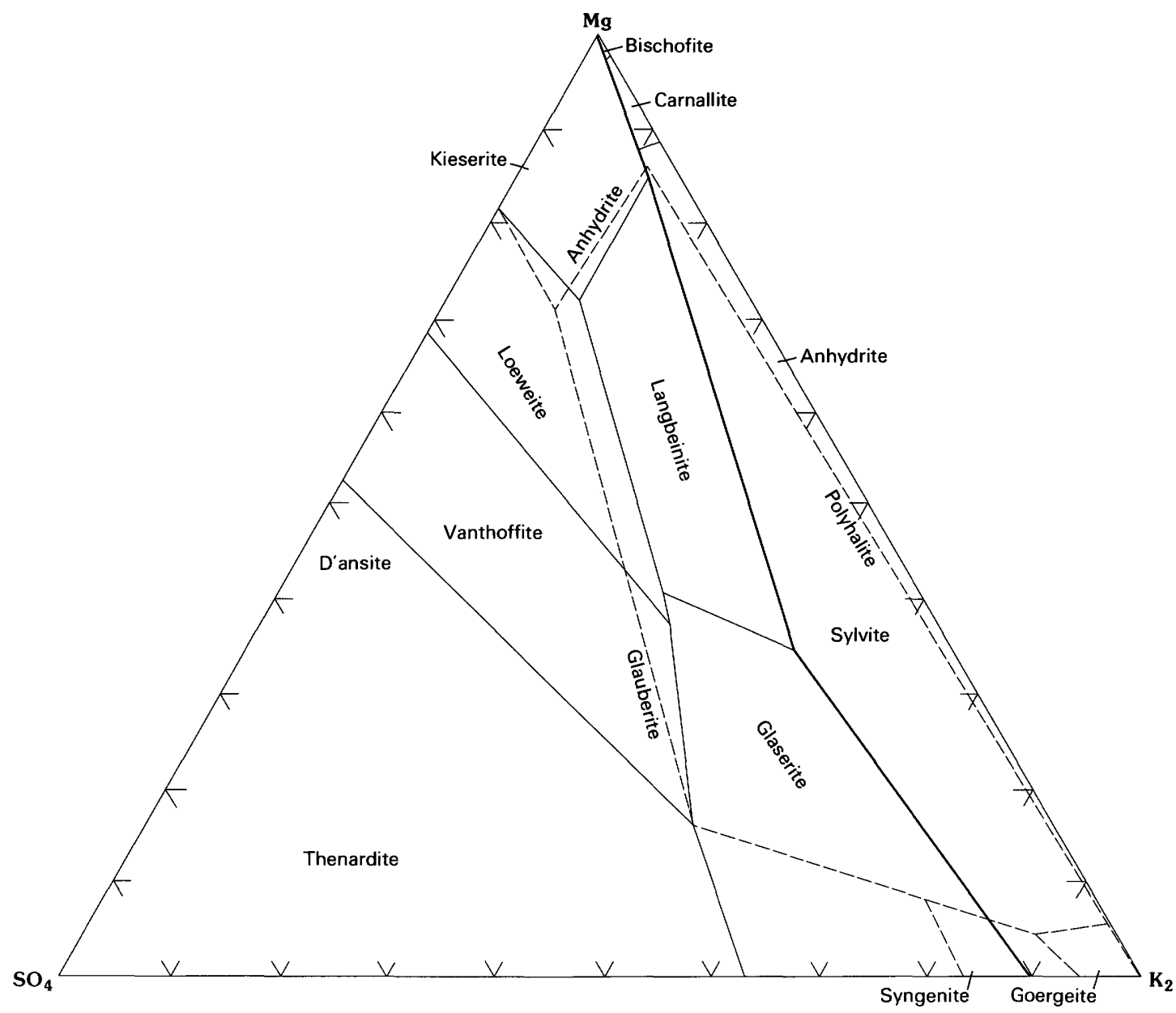

Figure $5.983^{\circ}-$ isotherm of the five-component system $\mathrm{NaCl}-\mathrm{KCl}-\mathrm{MgCl}_{2}-\mathrm{Na}_{2} \mathrm{SO}_{4}-\mathrm{H}_{2} \mathrm{O}$ at sodium cloride saturation (modified from Braitsch, 1971). Calcium-sulfate fields (dashed lines) approximated. Crystallization paths are heavy lines; transition lines, fine lines.

Table 5.3. Kinetic reactions for which data are needed [All reactions are in the presence of brines]

\begin{tabular}{|c|c|c|c|}
\hline \multicolumn{3}{|c|}{ Reaction } & \multirow{2}{*}{$\begin{array}{c}\begin{array}{c}\text { Temperature } \\
\text { range } \\
\left({ }^{\circ} \text { Celsius }\right)\end{array} \\
0.50\end{array}$} \\
\hline Gypsum & $=$ & anhydrite & \\
\hline Anhydrite & 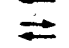 & polyhalite & $25-300$ \\
\hline Gypsum & $\Rightarrow$ & polyhalite & $0-50$ \\
\hline Bassanite & $\Rightarrow$ & anhydrite & $25-200$ \\
\hline Anhydrite & $\Rightarrow$ & goergeyite & $25-200$ \\
\hline Anhydrite & $\Rightarrow$ & glauberite & $25-200$ \\
\hline
\end{tabular}

decreases their thermal stability. Indirect evidence, such as the absence of any change in color of anhydrite exposed to high-level waste during project Salt Vault (Bradshaw and McClain, 1971), may indicate that the effects are probably slight; however, experimental studies are needed to document the presence or absence of radiation effects.

\section{SUMMARY}

Data collected from the literature on the chemical properties of anhydrite support the concept of using anhydrite as a waste-repository medium or as an overpack to protect high-level waste canisters. Available thermodynamic, crystallographic, and phase-equilibria data are extensive, and only limited additional data are needed in these areas to assess the behavior of a waste repository in anhydrite. However, data on the reaction kinetics of anhydrite alteration, on the sorption of radionuclides by anhydrite, and on the effects of radiation on anhydrite chemistry are not sufficient for evaluating anhydrite as a potential repository media.

The thermochemical properties of anhydrite $\left(\mathrm{CaSO}_{4}\right)$ and gypsum $\left(\mathrm{CaSO}_{4} \cdot 2 \mathrm{H}_{2} \mathrm{O}\right)$ are well known; two mutually consistent and verified sets of data are 
available. The data for the lower hydrates of calcium sulfate (bassanite, $\mathrm{CaSO}_{4} \cdot 0.5 \mathrm{H}_{2} \mathrm{O}$; "soluble anhydrite," $\mathrm{CaSO}_{4} \cdot n \mathrm{H}_{2} \mathrm{O}$ ) are inadequate, but these are metastable phases that would not be expected to occur under equilibrium conditions; they could be involved in the alteration of anhydrite if a repository flooded after a thermal pulse. Thermochemical data for the calcium sulfate-water system are adequate.

Crystallographic data on both anhydrite and gypsum are adequate; powder $\mathrm{X}$-ray diffraction data are available and the anhydrite and gypsum crystal structures are known. However, crystallographic data for the lower hydrates of calcium sulfate are inadequate; available data are contradictory and need clarification. These data would be of use in kinetic studies of the hydration of anhydrite. Additional data would have to be obtained using a high-resolution electron microscope with diffraction capabilities, because available evidence suggests the presence of fine intergrowths and structural zones.

Phase-equilibria and solubility data for anhydrite and other phases of calcium sulfate are voluminous. Data for high temperatures indicate that the solubility of anhydrite remains low and retains its retrograde character to $200{ }^{\circ} \mathrm{C}$, a temperature that is not likely to be exceeded in the rocks around a waste repository according to present design estimates. The only possibility for reversing the retrograde solubility at less than $200{ }^{\circ} \mathrm{C}$ would be if the change in solubility of anhydrite with pressure in concentrated brines is significantly greater than it is in sodium chloride-saturated solutions. The data necessary to evaluate this effect are unavailable; however, such data could be obtained readily using a gold-bag autoclave system.

Data on phase equilibria in the system Na-K$\mathrm{Mg}-\mathrm{Ca}-\mathrm{Cl}-\mathrm{SO}_{4}$ are necessary to assess the consequences of repository flooding after a thermal pulse. Available data for low-temperature equilibria are extensive and suggest that if anhydrite alters, the product would be gypsum or polyhalite, depending upon the composition of the brine. Alteration of anhydrite would increase the rock volume, which might reduce its permeability and restrict migration of fluids through the repository. If the initial porosity were low, however, the volume expansion could cause fracturing and thereby significantly increase migration of fluid. More data on the kinetics of alteration reactions are needed for a full assessment, because anhydrite alteration reactions proceed slowly at low temperatures.

Anhydrite rocks typically contain small amounts of other minerals, and therefore the stability of anhydrite coexisting with carbonate, silicate, and bittern-mineral impurities at elevated temperature and pressure should be evaluated. Sparse data suggest that significant problems will not be encountered, but more experimental data on these equilibria should be obtained using a gold-bag autoclave system.

The sorptive capacity of anhydrite appears to be significantly greater than that of halite, and for some radionuclides greater than that of tuff. However, data are too limited for adequate evaluation.

No data are available on the effects of radiation on the chemistry of anhydrite. 



\section{REFERENCES CITED}

Adams, G. I, and others, 1904, Gypsum deposits in the United States: U.S. Geological Survey Bulletin 223, 129 p.

Adams, J. E., 1944, Upper Permian Ochoa series of Delaware basin, West Texas and southeastern New Mexico: American Association of Petroleum Geologists Bulletin, v. 28, p. 1596-1625.

1965, Stratigraphic-tectonic development of Delaware Basin: American Association of Petroleum Geologists Bulletin, v. 49, p. 2140-2148.

Adams, S. S., 1969, Bromine in the Salado Formation, Carlsbad potash district, New Mexico: New Mexico Bureau of Mines and Mineral Resources Bulletin 93, 122 p.

Akin, R. H., Jr., and Graves, R. W., Jr., 1969, Reynolds oolite of southern Arkansas: American Association of Petroleum Geologists Bulletin, v. 53, p. 1909-1922.

Albritton, C. C., Jr., and Smith, J. F., Jr., 1965, Geology of the Sierra Blanca area, Hudspeth County, Texas: U.S. Geological Survey Professional Paper 479, $131 \mathrm{p}$.

Allen, D. G., 1971, The origin of sheet fractures in the Galore Creek copper deposits, British Columbia: Canadian Journal of Earth Sciences, v. 8, no. 6., p. 704-711.

Alling, H. L., and Briggs, L. I., 1961, Stratigraphy of Upper Silurian Cayugan evaporites: American Association of petroleum Geologists Bulletin, v. 45, p. 515-547.

Anderson, R. E., Eargle, D. H., and Davis, B. O., 1973, Geologic and hydrologic summary of salt domes in Gulf Coast region of Texas, Louisiana, Mississippi, and Alabama: U.S. Geological Survey Open-file report, 294 p.

Anderson, R. Y., 1982, Deformation-dissolution potential of bedded salt, waste isolation pilot plant site, Delaware basin, New Mexico, in Lutze, Werner, ed., Scientific basis for waste management: Amsterdam, Elsevier, p. $449-458$.

Anderson, R. Y., Dean, W. E., Jr., Kirkland, D. W., and Snider, H. I., 1972, Permian Castile varved evaporite sequence, west Texas and New Mexico: Geological Society of America Bulletin, v. 83, p. 59-86.

Anderson, R. Y., Kietzke, K. K., and Rhodes, D. J., 1978, Development of dissolution breccias, northern Delaware basin, New Mexico and Texas, in Austin, G. S., compiler, Geology and mineral deposits of Ochoan rocks in Delaware basin and adjacent areas: New Mexico Bureau of Mines and Mineral Resources Circular 159, p. 47-52.

Anderson, R. Y., and Kirkland, D. W., 1960, Origin, varves, and cycles of the Jurassic Todilto Formation, New Mexico: Amcrican Association of Petroleum Geologists Bulletin, v. 44 , p. $37-52$.

1966, Intrabasin varve correlation: Geological Society of America Bulletin, v. 77, p. 241-256.

1980, Dissolution of salt deposits by brine density flow: Geology, v. 8, p. 66-69.
Andrichuk, J. M., 1951, Regional stratigraphic analysis of Devonian System in Wyoming, Montana, southern Saskatchewan, and Alberta: American Association of Petroleum Geologists Bulletin, v. 35, p. 2368-2408.

1958, Mississippian Madison stratigraphy and sedimentation in Wyoming and southern Montana, in Weeks, L. G., ed., Habitat of oil-A symposium: Tulsa, Okla., American Association of Petroleum Geologists Special Symposium Volume, p. 225-267.

Applin, P. L., and Applin, E. R., 1965, The Comanchean Series and associated rocks in the subsurface in central and south Florida: U.S. Geological Survey Professional Paper 447, 84 p.

Arbital, J., Myrick, T., and Wilems, R., 1979, An overview of international nuclear fuel-cycle evaluations (INFCE) support, in, National Waste Terminal Storage Program Information Meeting, Columbus, Ohio, 1979: Office of Nuclear Waste Isolation Report ONWI-62, p. 228-232.

Archbold, N. L., 1969, Industrial mineral deposits, in Moore J. G., Geology and mineral deposits of Lyon, Douglas, and Ormsby Counties, Nevada: Nevada Bureau of Mines Bulletin 75, p. 31-41.

Atwater, G. I., and Forman, M. J., 1959, Nature of growth of southern Louisiana salt domes and its effect on petroleum accumulation: American Association of Petroleum Geologists Bulletin, v. 43, p. 2592-2622.

Autenrieth, H., 1958, Untersuchungen am Sechs-Komponenten-System $\mathrm{K}, \mathrm{Na}, \mathrm{Mg}, \mathrm{Ca}, \mathrm{SO}_{4}, \mathrm{Cl}, \mathrm{H}_{2} \mathrm{O}$ mit Schlussfolgerungen für die Verarbeitung der Kalisalze: Kali und Steinsalz, v. 2, p. 181-200.

Baar, C. A., 1977, Applied salt-rock mechanics 1: New York, Elsevier, 294 p.

Baars, D. L., 1972, Devonian System, in Geologic atlas of the Rocky Mountain region: Rocky Mountain Association of Geologists, p. 90-99.

Bailey, H. B., and Fredericton, N. B., 1931, Hydration factors in gypsum deposits of the Maritime Provinces: American Institute of Mining and Metallurgical Engineers Transactions, v. 96, p. 177-186.

Baker, A. A., Dane, C. H., and Reeside, J. B., Jr., 1936, Correlation of the Jurassic formations of parts of Utah, Arizona, New Mexico, and Colorado: U.S. Geological Survey Professional Paper 183, 66 p.

Ballard, W. W., 1969, Red River of northeast Montana and northwest North Dakota, in Montana Geological Society Guidebook, 20th Annual Field Conference, Eastern Montana symposium 1969: p. 15-24.

Barnes, V. E., 1943, Gypsum in the Edwards Limestone of Central Texas: University of Texas Publication 4301, p. $35-46$. 
Baron, G., Habib, P., and Morlier, P., 1963, Déformations des roches sous contraintes: Revue de l'Institut Français du Pétrole, p. 97-130.

Bates, R. L., 1955, Permo-Pennsylvanian formations between Laramie Mountains, Wyoming, and Black Hills, South Dakota: American Association of Petroleum Geologists Bulletin, v. 39, p. 1979-2002.

Bay, T. A., Jr., 1977, Lower Cretaceous stratigraphic models from Texas and Mexico, in Cretaceous carbonates of Texas and Mexico, applications to subsurface exploration: Texas Bureau of Economic Geology Report of Investigations 89, p. 12-30.

Beales, F. W., and Oldershaw, A. E., 1969, Evaporite-solution brecciation and Devonian carbonate reservoir porosity in western Canada: American Association of Petroleum Geologists Bulletin, v. 53, no. 3, p. 503-512.

Belyea, H. R., 1958, Devonian sediments in southern Alberta and correlations with northwestern Montana, in Billings Geological Society Guidebook, 9th annual field conference, Beartooth uplift and Sunlight basin, 1958: p. 49-56.

Bendel, Ludwig, 1948, Ingenieurgeologic: Vienna, SpringerVerlag, $832 \mathrm{p}$.

Billings Geological Society, 1962, Stratigraphic cross sections of Devonian strata Montana and surrounding areas, in Billings Geological Society Guidebook, 13th annual field conference, Three Forks-Belt-Mountain area and the symposium of the Devonian System of Montana and adjacent areas, 1962: p. 1 and 4 cross sections.

Bischoff, J. L., and Seyfried, W. E., 1978, Hydrothermal chemistry of seawater from $25^{\circ}$ to $350^{\circ} \mathrm{C}$ : American Journal of Science, v. 278, p. 838-860.

Bissell, H. J., 1964, Ely, Arcturus, and Park City Groups (Pennsylvanian-Permian) in eastern Nevada and western Utah: American Association of Petroleum Geologists Bulletin, v. 48, p. 565-636.

1969, Permian and Lower Triassic transition from the shelf to basin (Grand Canyon, Arizona to Spring Mountain, Nevada), in Four Corners Geological Society Guidebook, 5th field conference, Geology and natural history of the Grand Canyon region, 1969: p. 135-169.

1970, Realms of Permian tectonism and sedimentation in western Utah and eastern Nevada: American Association of Petroleum Geologists Bulletin, v. 54, p. 285-312.

Blankennagel, R. K., Howells, L. W., Miller, W. R., and Hansen, C. V., 1979, Preliminary data for Madison Limestone test well 3, NW1/4SE1/4, sec. 35, T. 2 N., R. 27 E., Yellowstone County, Montana: U.S. Geological Survey Open-File Report 79-745, 186 p.

Blazenko, E. J., 1964, Geology of the South Erick gas area, Beckham and Greer Counties, Oklahoma: Shale Shaker, v. 15 , no. 4 , p. $53-78$.

Blount, C. W., and Dickson, F. W., 1969, The solubility of anhydrite $\left(\mathrm{CaSO}_{4}\right)$ in $\mathrm{NaCl}-\mathrm{H}_{2} \mathrm{O}$ from $100^{\circ}$ to $450^{\circ} \mathrm{C}$ and 1 to 1,000 bars: Geochimica et Cosmochimica Acta, v. 33 , p. $227-245$.
Bodenlos, A. L., 1970, Cap-rock development and salt-stock movement, in Geology and technology of Gulf Coast salt-A symposium: Baton Rouge, La., Louisiana State University, School of Geoscience, p. 73C-86C.

Booth, H. S., and Bidwell, R. M., 1950, Solubilities of salts in water at high temperatures: Journal of the American Chemical Society, v. 72, p. 2567-2575.

Bradshaw, R. L., and McClain, W. C., eds., 1971, Project Salt Vault-A demonstration of the disposal of high activity wastes in underground salt mines: Oak Ridge National Laboratory Report ORNL-4555, 356 p.

Brady, F. H., 1958, Evaporite deposits in the Minnelusa Formation in the Sundance-Beulah area, Crook County, Wyoming, in Wyoming Geological Association Guidebook, 13th Annual Field Conference, Powder River Basin, 1958: p. 45-47.

Braitsch, O., 1971, Salt Deposits-Their origin and composition: New York, Springer-Verlag, $297 \mathrm{p}$.

Branstein, J., 1970, Bibliography of Gulf Coast geology: Gulf Coast Association of Geological Societies Publication, $681 \mathrm{p}$.

Braunstein, J., and O'Brien, G. D., 1968, Indexed bibliography of diapirism and diapirs, in Braustein, J., and O'Brien, G. D., Diapirism and diapirs-A symposium: American Association of Petroleum Geologists Memoir 8, p. 358-414.

Bredehoeft, J. D., England, A. W., Stewart, D. B., Trask, N. J., and Winograd, I. J., 1978, Geologic disposal of high-level radioactive wastes-Earth-science perspectives: U.S. Geological Survey Circular 779, 15 p.

Briggs, L. I., 1958, Evaporite facies: Journal of Sedimentary Petrology, v. 28, p. 46-56.

1959, Physical stratigraphy of lower Middle Devonian rocks in the Michigan basin, in Geology of Mackinac Island and Lower and Middle Devonian south of the Straits of Mackinac: Michigan Basin Geological Society Annual Geological Excursion Guidebook, p. 39-58.

1968, Gcology of subsurface waste disposal in Michigan basin, in Subsurface disposal in geologic basins-A study of reservoir strata: American Association of Petrolcum Geologists Memoir 10, p. 128-153.

1970, Geology of gypsum in the Lower Peninsula, Michigan, in Sixth forum on geology of industrial minerals: Michigan Geological Survey Miscellany 1, p. 66-76.

Briggs, L. I., and Briggs, Darinka, 1974, Niagara-Salina relationships in the Michigan basin, in Michigan Basin Geological Sucicty, field conference, Silurian reefevaporite relationships, 1974: p. 1-23.

Brokaw, A. L., Jones, C. L., Cooley, M. E., and Hays, W. H., 1972, Geology and hydrology of the Carlsbad potash area, Eddy and Lea Counties, New Mexico: U.S. Geological Survey Open-File report, 86 p.

Brown, J. S., 1973, Sulfur isotopes of Precambrian sulfates and sulfides in the Grenville of New York and Ontario: Economic Gcology, v. 68, p. 362-370.

Brown, J. S., and Engel, A.E.G., 1956, Revision of Grenville stratigraphy and structure in the Balmat-Edwards district, northwest Adirondacks, New York: Geological Society of America Bulletin, v. 67, p. 1599-1622. 
Brown, S. C., and Lauth, R. E., 1958, Oil and gas potentialities of northern Arizona, in New Mexico Geological Society, 9th field conference, Guidebook of the Black Mesa basin, northeastern Arizona, 1958: p. 153-160.

Brúne Gunnar, 1965, Anhydrite and gypsum problems in engineering: Engineering Geology, v. 2, no. 1, p. 26-38.

Budros, Ron, and Briggs, L. I., 1977, Depositional environment of Ruff Formation (Upper Silurian) in southeastern Michigan, in Fisher, J. A., ed., Reefs and evaporites-Concepts and depositional models: American Association of Petroleum Geologists Studies in Geology 5, p. 53-71.

Bullard, E. C., and Niblett, E. R., 1951, Terrestrial heat flow in England: Royal Astronomical Society Monthly Notices, v. 6 , no. 4 , p. $222-238$.

Bullock, J. M., and Wilson, W. H., 1969, Gypsum deposits in the Cody area, Park County, Wyoming: Geological Survey of Wyoming Preliminary Report 9, 12 p.

Bundy, W. M., 1956, Petrology of gypsum-anhydrite deposits in southwestern Indiana: Journal of Sedimentary Petrology, v. 26, p.240-252.

Bunn, C. W., 1941, Applications of X-ray diffraction methods in industrial chemistry: Journal of Scientific Instruments, v. 18 , p. 72 .

Burchett, R. R., 1970, Occurrence of gypsum in the Johnson Shale (Permian) in Nemaha County, Nebraska: Nebraska Geological Survey Resource Report 3, 23 p.

Burk, C. A., Anderman, G. G., Berg, R. R., Faulkner, G. L., Gudim, C. J., McCrae, R. O., Mills, N. K., and Peterson, M. L., 1956, Wyoming stratigraphy, pt. 1, Subsurface stratigraphy of the pre-Niobrara formations in Wyoming: Wyoming Geological Association, 98 p.

Butler, G. P., 1969, Modern evaporite deposition and geochemistry of coexisting brines, the sabkha, Trucial Coast, Arabian Gulf: Journal of Sedimentary Petrology, v. 39, p. $70-89$.

Campbell, C. V., 1962, Depositional environments of Phosphoria Formation (Permian) in southeastern Bighorn basin, Wyoming: American Association of Petroleum Geologists Bulletin, v. 46, p. 478-503.

Cano, R. and Chatelain, P., 1958, Sur les products de deshydration du gypse: Bulletin de la Société Françoise de Mineralogie et de Crystallographie, v. 81, p. 10.

Carlson, C. G., and Anderson, S. B., 1965, Sedimentary and tectonic history of North Dakota part of Williston basin: American Association of Petroleum Geologists Bulletin, v. 49, p. 1833-1846.

Cater, F. W., 1970, Geology of the salt anticline region in southwestern Colorado: U.S. Geological Survey Professional Paper 637, $80 \mathrm{p}$.

Cheeseman, R. J., and Lorenz, J. C., 1977, Potash ore reserves in the proposed Waste Isolation Pilot Plant area, Eddy County, New Mexico: U.S. Geological Survey Open-File Report 78-828, 48 p.

Clark, S. P., ed., 1966, Handbook of physical constants: Geological Society of America Memoir 97, 587 p.

Clifford, M. J., 1973, Silurian rock salt of Ohio: Ohio Gcological Survey Report of Investigations 90, 42 p.
Clynne, M. A., and Potter, R. W. II, 1979, P-T-X relations of anhydrite and brine and their implications for the suitability of anhydrite as a nuclear waste repository medium, in McCarthy, G. J., ed., Scientific basis for nuclear waste management, v. 1: New York, Plenum Press, p. 323-328.

Cole, G. E., 1925, Gypsum in Ontario: Ontario Department of Mines Annual Report, v. 34, part 2, p. 1-34.

Cole, W. F. and Lancucki, C. J., 1974, A refinement of the crystal structure of gypsum, $\mathrm{CaSO}_{4} \cdot 2 \mathrm{H}_{2} \mathrm{O}$ : Acta Crystallographica, v. B30, p. 921-929.

Collinson, Charles, Becker, L. E., James, G. W., Koening, J. W., Swann, D. H., Carlson, M. P., and Dorheim, F. H., 1967, Devonian of the north-central region, United States, in Oswald, D. H., ed., International symposium on the Devonian System, Calgary, 1967: Alberta Society of Petroleum Geologists, v. 1, p. 933-971.

Colton, G. W., 1970, The Appalachian basin-Its depositional sequences and their geologic relationships, in Fisher, G. W., Pettijohn, F. J., Reed, J. C., Jr., and Weaver, K. N., eds., Studies of Appalachian geology-Central and southern: New York, John Wiley, p. 5-47.

Committee on Radioactive Waste Management, 1978, The geological criteria for suitable sites of high-level radioactive waste repositories: Washington D.C., National Academy of Sciences, $17 \mathrm{p}$.

Cook, C. W., 1976, A mechanical well log study of the Poplar interval of the Mississippian Madison Formation in North Dakota: North Dakota Geological Survey Report of Investigations $52,20 \mathrm{p}$.

Cooper, B. N., 1966, Geology of the salt and gypsum deposits in the Saltville area, Smyth and Washington Counties, Virginia, in Rau, J. L., ed., Second symposium on salt, 1966: Cleveland, Ohio, Northern Ohio Geological Society, v. 1, p 11-34.

Cooper, J. B., 1962, Ground-water investigations of the Project Gnome area, Eddy and Lea Counties, New Mexico: U.S. Geological Survey Report TEI-802, 67 p.

Coster, H. P., 1947, Terrestrial heat flow in Persia: Royal Astronomical Society Monthly Notices, v. 5, no. 5, p. 131-145.

Cox, E. R., 1967, Geology and hydrology between Lake McMillan and Carlsbad Springs, Eddy County, New Mexico: U.S. Geological Survey Water-Supply Paper 1828,48 p.

Craig, L. C., 1972, Mississippian System, in Geologic atlas of the Rocky Mountain region: Rocky Mountain Association of Geologists, p. 100--110.

Crider, A. F., 1929, Pine Island Deep Sands, Caddo Parish, Louisiana, in Structure of typical American oil fields, v. 2: American Association of Petroleum Geologists, p. 168-182.

Cys, J. M., 1978, Transitional nature and significance of the Castile-Bell Canyon contact, in Austin, G. S., compiler, Geology and mineral deposits of Ochoan rocks in Delaware basin and adjacent areas: New Mexico Bureau of Mines and Mineral Resources Circular 159, p. 53-56.

d'Ans, Jean, Bredtschneider, D., Eick, H., and Freund, H. E., 1955, Untersuchungen über die Calcium-sulfate: Kali und Steinsalz, v. 1, no. 9, p. 17-38. 
Davis, J. B., and Kirkland, D. W., 1970, Native sulfur deposition in the Castile Formation, Culberson County, Texas: Economic Geology, v. 65, p. 107-121.

Dean, W. E., 1967, Petrologic and geochemical variations in the Permian Castile varved anhydrite, Delaware basin, Texas and New Mexico: Albuquerque, N. Mex., University of New Mexico Ph. D. thesis, 326 p.

Dean, W. E., and Anderson, R. Y., 1974, Trace and minor element variations in the Permian Castile Formation, Delaware basin, Texas and New Mexico, revealed by varve correlation, in Coogan, A. H., ed., Fourth symposium on salt, Houston, Texas, 1974: Cleveland, Ohio, Northern Ohio Geological Society, v. 1, p. 275-285.

1978, Salinity cycles-Evidence for subaqueous deposition of the Castile Formation and lower part of Salado Formation, Delaware basin, Texas and New Mexico, in Austin, G. S., compiler, Geology and mineral deposits of Ochoan rocks in Delaware basin and adjacent areas: New Mexico Bureau of Mines and Mineral Resources Circular 159, p. 15-20.

Dean, W. E., Davies, G. R., and Anderson, R. Y., 1975, Sedimentological significance of nodular and laminated anhydrite: Geology, v. 3, p. 367-372.

Dean, W. E., and Tung, A. L., 1974, Trace and minor elements in anhydrite and halite, Supai Formation (Permian), east-central Arizona, in Coogan, A. H., ed., Fourth symposium on salt, Houston, Texas, 1974: Cleveland, Ohio, Northern Ohio Geological Society, v. 1, p. 287-301.

Deer, W. A., Howie, R. A., and Zussman, J., 1962, Rockforming minerals, v. 5: London, Lowe and Brydone, $371 \mathrm{p}$.

Dellwig, L. F., 1955, Origin of the Salina salt of Michigan: Journal of Sedimentary Petrology, v. 25, p. 83-110.

Dellwig, L. F., and Evans, Robert, 1969, Depositional processes in Salina salt of Michigan, Ohio, and New York: American Association of Petroleum Geologists Bulletin, v. 53, p. 949-956.

Dickinson, K. A., 1968a, Upper Jurassic stratigraphy of some adjacent parts of Texas, Louisiana, and Arkansas: U.S. Geological Survey Professional Paper 594-E, 25 p.

1968b, Petrology of the Buckner Formation in adjacent parts of Texas, Louisiana, and Arkansas: Journal of Sedimentary Petrology, v. 38, p. 555-567.

Dickson, F. W., Blount, C. W., and Tunnel, G., 1963, Use of hydrothermal solution equipment to determine the solubility of anhydrite in water from $100^{\circ}$ to $275^{\circ} \mathrm{C}$ and from 1 bar to 1,000 bars pressure: American Journal of Science, v. 261, p. 61-78.

Dorheim, F. H., and Campbell, R. B., 1958, Recent gypsum exploration in Iowa: Iowa Academy of Science Proceedings., v. 65, p. 246-253.

Dow, W. G., 1967, The Spearfish Formation in the Williston basin of western North Dakota: North Dakota Geological Survey Bulletin 52, 28 p.
Drescher, W. J., 1965, Hydrology of deep-well disposal of radioactive liquid wastes, in Fluids in subsurface environments-A symposium, Midland Texas, 1969: American Association of Petroleum Geologists Memoir 4, p. 399-406.

Durham, C. O., 1960, Interior salt domes and Tertiary stratigraphy of North Louisiana: Shreveport Geological Society Field Trip Guidebook, 147 p.

Dutton, S. P., Finley, R. J., Galloway, W. E., Gustavson, T. C., Handford, C. R., and Presley, M. W., 1979, Geology and geohydrology of the Palo Duro basin, Texas Panhandle: Texas Bureau of Economic Geology Geological Circular 79-1, $99 \mathrm{p}$.

Dyer, W. S., 1925, Geology of the gypsum deposits of southwestern Ontario: Ontario Department of Mines Report, v. 34, pt. 2, p. 35-58.

Dzens-Litovskiy, A. I., and Vasil'yev, G. V., 1962, Geologic conditions of formation of bottom sediments in Karabogaz-Gol in connection with fluctuations of the Caspian Sea level: Americal Geological Institute translation of Isvestiya Academy of Science USSR, Geological Series 3, p. 79-86.

Eaton, G. P., Peterson, D. L., and Schumann, H. H., 1972, Geophysical, geohydrological, and geochemical reconnaissance of the Luke salt body, central Arizona: U.S. Geological Survey Professional Paper 753, 28 p.

Eberly, L, D., and Stanley, T. B., Jr. 1978, Cenozoic stratigraphy and geologic history of southwestern Arizona: Geological Society of America Bulletin, v. 89, p. 921-940.

Eckel, E. C., 1903, Salt and gypsum deposits of southwestern Virginia: U.S. Geological Survey Bulletin 213, p. $406-416$.

Edie, R. W., 1958, Mississippian sedimentation and oil fields in southeastern Saskatchewan: American Association of Petroleum Geologists Bulletin, v. 42, no. 1, p. 94-126.

Ehman, D. A., 1964, Stratigraphic analysis of the Detroit River Group in the Michigan basin: Ann Arbor, University of Michigan M. S. thesis, 63 p.

Ellison, S. P., Jr., 1971, Sulfur in Texas: The University of Texas Bureau of Economic Geology Handbook 2, 48 p.

Ells, G. D., 1967, Michigan's Silurian oil and gas pools: Michigan Geological Survey Report of Investigations 2, $49 \mathrm{p}$.

Elston, D. P., and Shoemaker, E. M., 1961, Preliminary structure contour map on top of salt in the Paradox Member of the Hermosa Formation in the salt anticline region, Colorado and Utah: U.S. Geological Survey Oil and Gas Investigations Map OM-209.

Evans, H. T., Jr., 1979, The thermal expansion of anhydrite to $1,000^{\circ} \mathrm{C}$ : Physical Chemistry Minerals, v. 4, p. 77-82.

Farnsworth, M., 1924, Effects of temperature and pressure on gypsum and anhydrite: U.S. Bureau of Mines Report of Investigations 2654,3 p.

Fay, R. O., 1964, The Blaine and related formations of northwestern Oklahoma and southern Kansas: Oklahoma Geological Survey Bulletin 98, 238 p.

1965, Geology and mineral resources of Woods County, Oklahoma: Oklahoma Geological Survey Bulletin 106, $189 \mathrm{p}$. 
1979, Geology and mineral resources (exclusive of petroleum) of Custer County, Oklahoma: Oklahoma Geological Survey Bulletin 114, 88 p.

Fecly, H. W., and Kulp, J. L., 1957, Origin of Gulf Coast salt dome sulfur deposits: American Association of Petroleum Geologists Bulletin, v. 41, p. 1802-1853.

Feitz, R. P., 1976, Recent developments in Sunniland exploration of south Florida: Gulf Coast Association of Geological Societies Transactions, v. 26, p. 74-78.

Fergusson, W. B., and Prather, B. A., 1968, Salt deposits in the Salina Group in Pennsylvania: Pennsylvania Geological Survey, 4th ser., Bulletin M 58, 41 p.

Fisher, J. H., 1969, Early Paleozoic history of the Michigan basin, in Studies of the Precambrian of the Michigan basin: Michigan Basin Geological Society Annual Field Excursion Guidebook, p. 89-93.

Fisher, W. L., and Rodda, P. U., 1969, Edwards Formation (Lower Cretaceous), Texas-Dolomitization in a carbonate platform system: American Association of Petroleum Geologists Bulletin, v. 53, p. 55-72.

Florke, O. W., 1952, Kristallographische und rontgenometrische untersuchungen im system $\mathrm{CaSO}_{4}-\mathrm{CaSO}_{4} \cdot 2 \mathrm{H}_{2} \mathrm{O}$ : Neues Jahrbuch für Mineralogie Monatshefte, E. Schweizerbart'sche Verlagsbuchhandlung, v. 84 p. 289-240.

Forgotson, J. M., Jr., 1957, Stratigraphy of Comanchean Cretaceous Trinity Group: American Association of Petroleum Geologists Bulletin, v. 41, p. 2328-2363. 1958, A correlation and regional stratigraphic analysis of the formations of the Trinity Group of the Comanchean Cretaceous of the Gulf Coastal Plain; and the genesis and petrography of the Ferry Lake Anhydrite, in Reference report on certain oil and gas fields, v. IV: Shreveport Geological Society, p. 35-115.

1963, Depositional history and paleotectonic framework of Comanchean Cretaceous Trinity Stage, Gulf Coast area: American Association of Petroleum Geologists Bulletin, v. 47, p. 69-103.

Foster, D. I., 1958, Summary of the stratigraphy of the Minnelusa Formation, Powder River basin, Wyoming, in Wyoming Geological Association Guidebook, 13th Annual Field Conference, Powder River basin, 1958: p. 39-44.

Foster, R. W., Fentress, R. M., and Riese, W. C., 1972, Subsurface geology of east-central New Mexico: New Mexico Geological Society Special Publication 4, 22 p.

Fowler, P. T., 1964, Basement faults and Smackover structure: Gulf Coast Association of Geological Societies Transactions, v. 14, p. 179-190.

Francis, D. R., 1957, Jurassic stratigraphy of the Williston basin area: American Association of Petroleum Geologists Bulletin, v. 41, p. 367-398.

Freeman, W. E., 1976, Regional stratigraphy and depositional environments of the Glen Canyon Group and Carmel Formation (San Rafael Group), in Symposium on the geology of the Cordilleran hingeline, 1976: Rocky Mountain Association of Geologists Guidebook, p. 247-259.

French, R. R., and Rooncy, L. F., 1969, Gypsum resources of Indiana: Indiana Geological Survey Bulletin 42-A, 34 p.
Fried, S., Friedman, A. M., Cohen, D., Hines, J. J., Strickert, R., 1978, Annual report to the Office of Waste Handling, Project AN0115A: Argonne, Ill., Argonne National Laboratory, $71 \mathrm{p}$.

Frye, J. C., and Schoff, S. L., 1942, Deep-seated solution in the Meade basin and vicinity, Kansas and Oklahoma: American Geophysical Union Transactions, p. 35-39.

Fugate, R. J., 1968, The East Norwich field, in Symposium on Michigan oil and gas fields: Michigan Basin Geological Society, p. 69-86.

Fuller, J.G.C.M., 1961, Ordovician and contiguous formations in North Dakota, South Dakota, Montana, and adjoining areas of Canada and United States: American Association of Petroleum Geologists Bulletin, v. 45, p. 1334-1363.

Galley, J. E., 1958, Oil and geology in the Permian basin of Texas and New Mexico, in Weeks, L. G., ed., Habitat of oil-A symposium: Tulsa, Okla., American Association of Petroleum Geologists, Special Symposium Volume, p. 395-446.

Gard, L. M., Jr., 1976, Geology of the north end of the Salt Valley anticline, Grand County, Utah: U.S. Geological Survey Open-File Report 76-303, 35 p.

Gardner, W. C., 1974, Middle Devonian stratigraphy and depositional environments in the Michigan basin: Michigan Basin Geological Society Special Papers, no. 1, $138 \mathrm{p}$.

Gay, P., 1965a, Some crystallographic studies in the system $\mathrm{CaSO}_{4}-\mathrm{CaSO}_{4} \cdot 2 \mathrm{H}_{2} \mathrm{O}$ I. The polymorphism of anhydrous $\mathrm{CaSO}_{4}$ : Mineralogical Magazine, v. 35, p. 347-353.

$1965 \mathrm{~b}$, Some crystallographic studies in the system $\mathrm{CaSO}_{4}-\mathrm{CaSO}_{4} \cdot 2 \mathrm{H}_{2} \mathrm{O}$ II. The hydrous forms: Mineralogical Magazine, v. 35, p. 354-362.

Gera, Ferruccio, 1972, Review of salt tectonics in relation to the disposal of radioactive wastes in salt formations: Geological Society of America Bulletin, v. 83, p. 3551-3574.

Gignoux, M., and Barbier, R., 1955, Géologie des barrages et des amenagements hydrauliques: Paris, Masson et Compagnie, 343 p.

Gill, Dan, 1977, Salina A-1 sabkha cycles and the Late Silurian paleogeography of the Michigan basin: Journal of Sedimentary Petrology, v. 47, p. 979-1017.

Gilliland, W. N., 1951, Geology of the Gunnison quadrangle, Utah: Nebraska University Studies, new ser., no. 8, 101 p.

Glen, D. N., and Haines, D.A., 1970, Gypsum disodium pentacalcium sulfate and anhydrite solubilities in concentrated sodium chloride solutions: Canadian Journal of Chemistry, v. 48, p. 3373-3378.

Goldman, M. I. 1933, Origin of the anhydrite cap rock of American salt domes: U.S. Geological Survey Professional Paper 175, p. 83-114.

1952, Deformation, metamorphism, and mineralization in gypsum-anhydrite cap rock, Sulphur salt dome, Louisiana: Geological Society of America Memoir 50, 169 p.

Gould, C. N., 1905, Geology and water resources of Oklahoma: U.S. Geological Survey Water-Supply Paper 148, 178 p.

Grattan-Bellew, P. E., 1975, Effects of preferred orientation on $\mathrm{X}$-ray diffraction patterns of gypsum: American Mineralogist, v. 60, p. 1127-1129. 
Green, M. W., and Pierson, C. T., 1977, A summary of the stratigraphy and depositional environments of Jurassic and related rocks in the San Juan Basin, Arizona, Colorado and New Mexico, in New Mexico Geological Society Guidebook, 28th Field Conference, Guidebook to the San Juan basin III, 1977: p. 147-152.

Grimsley, G. P., 1904, The gypsum of Michigan and the plaster industry: Michigan Geological Survey, v. 9, pt. 2, 241 p.

Grimsley, G. P., and Bailey, E.H.S., 1899, Special report on gypsum and gypsum cement plasters: Kansas University Geological Survey, v. 5, 183 p.

Halbouty, M. T., 1967, Salt domes, Gulf region, United States and Mexico: Houston, Tex., Gulf Publishing Company, $425 \mathrm{p}$.

Ham, W. E., and Curtis, N. M., 1958, Gypsum in the Weatherford-Clinton district, Oklahoma: Oklahoma Geological Survey Mineral Report 35, 32 p.

Handin, J., and Hager, R. V., 1957, Experimental deformation of sedimentary rocks under confining pressure-Tests at room temperature on dry samples: American Association of Petroleum Geologists Bulletin, v. 41, no. 1, p. 1-50.

1958, Experimental deformation of sedimentary rocks under confining pressure-Tests at high temperature: American Association of Petroleum Geologists Bulletin, v. 42 , p. $2892-2934$

Hanna, M. A., 1959, Salt domes-Favorite home of oil: Oil and Gas Journal, v. 57, no. 6, p. 138-142.

Hara, R., Tanaka, Y., and Nakamura, K., 1934, On the calcium sulphate in sea water, I. Solubilities of dihydrate and anhydrite in the sea waters of various concentrations at $0^{\circ}-200{ }^{\circ} \mathrm{C}$ : Tohoku University Technical Reports, v. 11, p. 199-221.

Hardie, L. A., 1965, Phase equilibria involving minerals in the system $\mathrm{CaSO}_{4}-\mathrm{Na}_{2} \mathrm{SO}_{4}-\mathrm{H}_{2} \mathrm{O}$ : Baltimore, Md., Johns Hopkins University $\mathrm{Ph}$. D. thesis, $260 \mathrm{p}$.

1967, The gypsum-anhydrite equilibrium at one atmosphere pressure: American Mineralogist, v. 52, p. 171-200.

Hardy, C. T., 1952, Eastern Sevier Valley, Sevier and Sanpete Counties, Utah: Utah Geological and Mineralogical Survey Bulletin 43, 98 p.

Hartman, J. K., and Woodard, L. R., 1971, Future petroleum resources in post-Mississippian strata of north, central, and west Texas and eastern New Mexico, in Cram, I. H., ed., Future petroleum provinces of the United StatesTheir geology and potential: American Association of Petroleum Geologists Memoir 15, v. 1, p. 752-800.

Havenor, K. C., 1968, Structure, stratigraphy, and hydrogeology of the northern Roswell artesian basin, Chaves County, New Mexico: New Mexico Bureau of Mines and Mineral Resources Circular 93, $30 \mathrm{p}$.

Hawkins, M. E., and Jirik, C. J., 1966, Salt domes in Texas, Louisiana, Mississippi, Alabama and offshore tidelands-A survey: U.S. Bureau of Mines Information Circular 8313, 78 p.

Hayes, P. T., 1964, Geology of the Guadalupe Mountains, New Mexico: U.S. Geological Survey Professional Paper 446, $69 \mathrm{p}$.
Hazzard, R. T., Spooner, W. C., and Blanpied, B. W., 1947, Notes on the stratigraphy of the formations which underlie the Smackover Limestone in south Arkansas, northeast Texas and north Louisiana, in 1945 Reference report on certain oil and gas fields of north Louisiana, south Arkansas, Mississippi, and Alabama, v. II: Shreveport Geological Society, p. 483-503.

Heard, H. C., and Rubey, W. W., 1964, Possible tectonic significance of transformation of gypsum to anhydrite plus water, in Abstracts for 1963: Geological Society of America Special Paper 76, p. 77-78.

Henry, J., and Zolnai, G., 1971, Resedimentation of the Triassic in the southwestern Aquitaine basin: Bulletin du Centre de Recherches de Pau, v. 5, no. 2, p. 389-398.

Hensler, Eric, 1968, Some examples from the south Harz region of cavern formation in gypsum: Transactions of Cave Research Group of Great Britain, v. 10, no. 1, p. 33-44. Herman, G., and Barkell, C. A., 1957, Pennsylvanian stratigraphy and productive zones, Paradox salt basin: American Association of Petroleum Geologists Bulletin, v. 41, p. 861-881.

Herman, G., and Sharps, S. L., 1956, Pennsylvanian and Permian stratigraphy of the Paradox salt embayment: Intermountain Association of Petroleum Geologists, 7th Annual Field Conference, 1956, p. 77-84.

Herrin, Eugene, and Clark, S. P., Jr., 1956, Heat flow in west Texas and eastern New Mexico: Geophysics, v. 21, no. 4, p. 1087-1099.

Heyman, Louis, 1977, Tully (Middle Devonian) to Queenston (Upper Ordovician) correlations in the subsurface of western Pennsylvania: Pennsylvania Geological Survey, 4th series, Mineral Resource Report 73, 16 p.

Hickey, H. N., committee chairman, 1972, Tectonic map of Gulf Coast region U.S.A.: Gulf Coast Association of Geological Societies and American Association of Petroleum Geologists, scale 1:1,000,000.

Hite, R. J., 1960, Stratigraphy of the saline facies of the Paradox Member of the Hermosa Formation of southeastern Utah and southwestern Colorado, in Geology of the Paradox basin fold and fault belt, 1960: Four Corners Geological Society Guidebook, 3rd Field Conference, p. 86-89.

1968, Salt deposits of the Paradox basin, southeast Utah and southwest Colorado, in Mattox, R. B., ed., Saline deposits: Geological Society of America Special Paper 88, p. 319-330.

1970, Shelf carbonate sedimentation controlled by salinity in the Paradox basin, southeast Utah, in Rau, J. L., and Dellwig, L. F., eds., Third symposium on salt, 1969: Cleveland, Ohio, Northern Ohio Geological Society, v. 1, p. 48-66.

1977, Subsurface geology of a potential waste emplacement site, Salt Valley anticline, Grand County, Utah: U.S. Geological Survey Open-File Report 77-761, $26 \mathrm{p}$.

Hite, R. J., and Liming, J. A., 1972, Stratigraphic section through the Pennsylvanian System in the Paradox basin, in Geologic atlas of the Rocky Mountain region: Rocky Mountain Association of Geologists, p. 134-135. 
Hite, R. J., and Lohman, S. W., 1973, Geologic appraisal of Paradox basin salt deposits for waste emplacement: U.S. Geological Survey Open-file report, 75 p.

Hodgkinson, K. A., 1961, Permian stratigraphy of northeastern Nevada and northwestern Utah: Brigham Young University Geology Studies, v. 8, p. 167-196.

Hoen, E. W., 1964, The anhydrite diapirs of central western Axel Heiberg Island: Montreal, McGill University, Axel Heiberg Island Research Reports, Geology, no. 2, 102 p.

Hofer, K. H., and Menzel, W., 1964, Comparative study of pillar loads in potash mines established by calculation and by measurements below ground: International Journal of Rock Mechanics and Mining Sciences, v. 1, p. 181-198.

Holdoway, K. A., 1978, Deposition of evaporites and red beds of the Nippewalla Group, Permian, western Kansas: Kansas Geological Survey Bulletin 215, 43 p.

Holliday, D. W., 1970, The petrology of secondary gypsum rocks-A review: Journal of Sedimentary Petrology, v. 40 , no. 2 , p. 734-744.

Holser, W. T., 1966, Diagenetic polyhalite in recent salt from Baja California: American Mineralogist, v. 51, p. 99-109.

Howitt, F., 1964, Stratigraphy and structure of the Purebeck inliers of Sussex, England: Quarterly Journal of the Geological Society of London, v. 120, p. 77-113.

Hoy, R. B., Foose, R. M., and O'Neill, B. J., Jr., 1962, Structure of Winnfield salt dome, Winn Parish, Louisiana: American Association of Petroleum Geologists Bulletin, v. 46, no. 8, p. 1444-1459.

Hoyt, J. H., 1963, Permo-Pennsylvanian correlations and isopach studies in the Northern Denver basin, in Guidebook to the geology of the northern Denver basin and adjacent uplifts, 1963: Rocky Mountain Association of Geologists Guidebook, 14th Field Conference, p. 68-83.

Huh, J. J., Briggs, L. I., and Gill, Dan, 1977, Depositional environments of pinnacle reefs, Niagaran and Salina Groups, northern shelf, Michigan Basin, in Fisher, J. H., ed., Reefs and evaporites-Concepts and depositional models: American Association of Petroleum Geologists Studies in Geology 5, p. 1-21.

Hulett, G. A., and Allen, L. E., 1902, The solubility of gypsum: Journal of the American Chemical Society, v. 24, p. 667-679.

Ibrahim, M. A., and Katz, D. L., 1972, Evaluation of capillary properties of cap rocks, in Second symposium on fundamentals of transport phenomena in porous media, University of Guelph, Ontario, August 7-11, 1972, Proceedings: Woodstock, Ontario, Huddleston and Barney Ltd., v. 1 p. 137-154.

Imlay, R. W., 1943, Jurassic formations of Gulf region: American Association of Petroleum Geologists Bulletin, v. 27, p. 1407-1533.

International Atomic Energy Agency, 1977, Site selection factors for repositories of solid high-level and alphabearing wastes in geologic formations: Vienna, International Atomic Energy Agency Technical Report, ser. $177,64 \mathrm{p}$.
Irwin, C. D., 1971, Stratigraphic analysis of Upper Permian and Lower Triassic strata in southern Utah: American Association of Petroleum Geologists Bulletin, v. 55, p. 1976-2007.

Irwin, Dennis, 1977, Subsurface cross sections of Colorado: Rocky Mountain Association of Geologists Special Publication 2, 39 p.

Jacoby, C. H., 1969, Correlation, faulting, and metamorphism of Michigan and Appalachian basin salts: American Association of Petroleum Geologists Bulletin, v. 53, p. 136-154.

James, A. N., and Lupton, A.R.R., 1978, Gypsum and anhydrite in foundations of hydraulic structures: Geotechnique, v. 28 , no. 3, p. 249-272.

Jensen, M. L., 1968, Isotopic geology and the origin of Gulf Coast and Sicilian sulfur deposits, in International conference on saline deposits, 1962: Geological Society of America Special Paper 88, p. 525-536.

Johnson, K. S., 1967, Stratigraphy of the Blaine Formation and associated strata in southwestern Oklahoma: Urbana, Ill., University of Illinois. $\mathrm{Ph}$. D. thesis, $247 \mathrm{p}$.

1976, Evaluation of Permian salt deposits of the Texas Panhandle and western Oklahoma for underground storage of radioactive wastes: Prepared for Union Carbide Corporation, Nuclear Division, Office of Waste Isolation, Y/OWI/SUB-4494/1, 73 p.

1978a, Stratigraphy and mineral resources of Guadalupian and Ochoan rocks in the Texas Panhandle and western Oklahoma, in Austin, G. S., compiler, Geology and mineral resources of Ochoan rocks in Delaware basin and adjacent areas: New Mexico Bureau of Mines and Mineral Resources Circular 159, p. 57-62.

1978b, Major gypsum districts of western Oklahoma, in Johnson, K. S., and Russell, J. A., eds., Thirteenth annual forum on the geology of industrial minerals, Norman, Oklahoma, 1977: Oklahoma Geological Survey Circular 79, p. 6-14.

Johnson, K. S., and Gonzales, Serge, 1976, Geology and salt deposits of the Michigan basin: Prepared for Union Carbide Corporation, Nuclear Division, Office of Waste Isolation, Y/OWI/SUB-4494/2, $60 \mathrm{p}$.

1978, Salt deposits in the United States and regional geologic characteristics important for storage of radioactive waste: Prepared for Union Carbide Corporation, Nuclear Division, Office of Waste Isolation, Y/OWI/SUB-7414/1, 188 p.

Johnson, M. G., 1977, Geology and mineral deposits of Pershing County, Nevada: Nevada Bureau of Mines and Geology Bulletin 89, 115 p.

Jones, C. L., 1960, Thickness, character, and structure of Upper Permian evaporites in part of Eddy County, New Mexico: U.S. Geological Survey TEM-1033, 73 p.

1965, Petrography of evaporites from the Wellington Formation near Hutchinson, Kansas: U.S. Geological Survey Bulletin 1201-A, 67 p.

1974, Salt deposits of the Clovis-Portales area, eastcentral New Mexico: U.S. Geological Survey Open-File Report 74-60, 22 p. 
1975, Potash resources in part of the Los Medanos area of Eddy and Lea Counties, New Mexico: U.S. Geological Survey Open-File Report 75-407, 37 p.

Jones, C. L., Cooley, M. E., and Bachman, G. O., 1973, Salt deposits of Los Medanos area, Eddy and Lea Counties, New Mexico: U.S. Geological Survey Open-file report $67 \mathrm{p}$.

Jordan, Louise, and Vosburg, D. L., 1963, Permian salt and associated cvaporites in the Anadarko basin of the western Oklahoma-Texas Panhandle region: Oklahoma Geological Survey Bulletin 102, 76 p.

Jorgensen, D. B., and Carr, D. D., 1972, Influence of cyclic deposition, structural features, and hydrologic controls on evaporite deposits in the St. Louis Limestone in southwestern Indiana, in Eighth forum on geology of industrial minerals, Iowa City, Iowa, 1972: Iowa Geological Survey Public Information Circular 5, p. 43-65.

Judson, S. A., and Stamey, R. A., 1933, Overhanging salt on domes of Texas and Louisiana: American Association of Petroleum Geologists Bulletin, v. 17, no. 12, p. $1492-1520$.

Jung, H., 1925, Rontgenographische Untersuchungen an den Entwasserungsprodukten des Gipses: Zeitschrift für Anorganische und Allgemeine Chemie, Johann Ambrosius Barth Verlag: v. 142, p. 73.

Kahn, J. S., 1975, High-pressure phase transformation of $\mathrm{CaSO}_{4}$ (anhydrite) during a nuclear explosion: Science, v. 189 , no. 4201 , p. $454-455$.

Katich, P. J., Jr., 1958, Stratigraphy of the Eagle Evaporites, in Symposium on Pennsylvanian rocks of Colorado and adjacent areas, 1958: Rocky Mountain Association of Geologists, p. 106-110.

Kay, G. F., 1915, A new gypsum deposit in Iowa, in Contributions to economic geology 1913: U.S. Geological Survey Bulletin 580, p. 59-64.

Keevil, N. B., 1942, Vapor pressures of aqueous solutions at high temperatures: Journal of the American Chemical Society, v. 64 , p. 841-850.

Kelley, K. K., 1960, Contributions to the data on theoretical metallurgy, XIII-High temperature heat-capacity, and entropy data for the elements and inorganic compounds: U.S. Bureau of Mines Bulletin 584, 232 p.

Kelley, K. K., Southard, S. C., and Anderson, C. T., 1941, Thermodynamic properties of gypsum and its dehydration products: U.S. Bureau of Mines Technical Paper $625,73 \mathrm{p}$.

Kelley, V. C., 1971, Geology of the Pecos country, southeastern New Mexico: New Mexico Bureau of Mines and Mineral Resources Memoir 24, 75 p.

1972a, Geology of the Fort Summer sheet, New Mexico: New Mexico Bureau of Mines and Mineral Resources Bulletin 98, 55 p.

1972b, Outcropping Permian shelf formations of eastern New Mexico, in Kelley, V. C., and Trauger, F. D., eds., Guidebook of east-central New Mexico, 1972: New Mexico Geological Society Guidebook, 23rd Field Conference, p. 72-78.
Khan, A. A., 1976, Computer simulation of thermal expansion of noncubic crystals; fosterite, anhydrite, and scheelite: Acta Crystallographica, sec. A, v. A32, p. 11-16.

King, P. B., 1934, Permian stratigraphy of trans-Pecos Texas: Geological Society of America Bulletin, v. 45, p. 697-798.

1942, Permian of west Texas and southeastern New Mexico: American Association of Petroleum Geologists Bulletin, v. 26, p. 535-763.

1948, Geology of the southern Guadalupe Mountains, Texas: U.S. Geological Survey Professional Paper 215, 183 p.

King, R. H., 1947, Sedimentation in Permian Castile sea: American Association of Petroleum Geologists Bulletin, v. 31 , p. $470-477$.

Kinnison, P. T., 1971, Future petroleum potential of Powder River basin, southeastern Montana and northeastern Wyoming, in Cram, I. H., ed., Future petroleum provinces of the United States-Their geology and potential: American Association of Petroleum Geologists Memoir 15, v. 1, p. 591-612.

Kinsman, D. J. J., 1966, Gypsum and anhydrite of Recent age, Trucial Coast Persian Gulf, in Rau, J. L., ed., Second symposium on salt, 1965: Cleveland, Ohio, Northern Ohio Geological Society, v. 1, p. 302-326.

Kirkland, D. W., and Anderson, R. Y., 1970, Microfolding in the Castile and Todilto evaporites, Texas and New Mexico: Geological Society of America Bulletin, v. 81, p. 3259-3282.

Kirkland, D. W., and Evans, Robert, 1976, Origin of limestone buttes, Culberson County, Texas: American Association of Petroleum Geologists Bulletin, v. 60, no. 11,p. 2005-2018.

Kottlowski, F. E., Flower, R. H., Thompson, M. L., and Foster, R. W., 1956, Stratigraphic studies of the San Andres Mountains, New Mexico: New Mexico Bureau of Mines and Mineral Resources Memoir 1, 132 p.

Krumbein, W. C., 1951, Occurrence and lithologic associations of evaporites in the United States: Journal of Sedimentary Petrology, v. 21, no. 2, p. 63-81.

Kulstad, R. O., Fairchild, Paul, and McGregor, Duncan, 1956, Gypsum in Kansas: Kansas Geological Survey Bulletin $113,110 \mathrm{p}$.

Kupfer, D. H., 1963, Structure of salt in Gulf Coast domes, in First symposium on salt, 1963: Cleveland, Ohio, Northern Ohio Geological Society, p. 104-123.

Lafayette and New Orleans Geological Societies, 1968, Geology of natural gas in south Louisiana, in Beebe, B. W., ed., Natural gases of North America: American Association of Petroleum Geologists Memoir 9, p. $376-581$.

Lambert, S. J., 1978, Geochemistry of Delaware basin ground waters: New Mexico Bureau of Mines and Mineral Resources Circular 159, p. 33-38.

Lambert, S. J., and Mercer, J. W., 1977, Hydrologic investigations of the Los Medanos area, southwestern New Mexico: Sandia Laboratories Report 77-1401, 63 p.

Landes, K. K., 1945, The Salina and Bass Islands rocks in the Michigan basin: U.S. Geological Survey Oil and Gas Investigations Preliminary Map 40. 
1951, Detroit River group in the Michigan basin: U.S. Geological Survey Circular 133, 23 p.

1959, The Mackinac breccia, in Geology of Mackinac Island and Lower and Middle Devonian south of the Straits of Mackinac: Michigan Basin Geological Society Annual Geological Excursion Guidebook, p. 19-34.

1972, Possible salt mine sites for radioactive-waste disposal in the Northeastern States: Prepared for Union Carbide Corporation, Nuclear Division, Oak Ridge National Laboratory, ORNL/SUB-3733/1, 273 p.

Landes, K. K., Ehlers, G. M., Stanley, G. M., 1945, Geology of the Mackinac Straits region: Michigan Geological Survey Publication 44, 204 p.

Lane, D. W., 1973, The Phosphoria and Goose Egg Formations in Wyoming: Geological Survey of Wyoming Preliminary Report 12, 24 p.

Lang, W. B., 1935, Upper Permian formations of Delaware basin of Texas and New Mexico: American Association of Petroleum Geologists Bulletin, v. 19, p. 262-270. 1939, Salado Formation of the Permian basin: American Association of Petroleum Geologists Bulletin, v. 23, p. $1569-1572$.

Larson, W. S., and others, 1963, Cross sections, southeast Wyoming-northwest Nebraska-northeast Colorado, in Guidebook to the geology of the Northern Denver basin and adjacent uplifts, 1963: Rocky Mountain Association of Geologists Guidebook, 14th Field Conference, 3 cross sections.

Laubscher, H. P., 1975, Viscous components in Jura folding: Tectonophysics, v. 27, p. 239-254.

Ledbetter, J. O., Kaiser, W. R., and Ripperger, E. A., 1975, Radioactive waste management by burial in salt domes: U.S. Atomic Energy Commission Contract Report AT-(40-1)-4639, 82 p.

Lee, W. T., 1925, Erosion by solution and fill: U.S. Geological Survey Bulletin 760, p. 107-121.

Link, H., 1962, On Poisson's numbers for rock samples and rock masses: Geologie und Bauwesen, v. 27, no. 2, p. $89-100$.

Linter, E. J., 1937, Methods and costs of mining and crushing gypsum at the mine of the Victor Plaster, Inc., Victor, N.Y.: U.S. Bureau of Mines Information Circular 6967, $18 \mathrm{p}$.

Lintz, Joseph, Jr., 1957, Nevada oil and gas drilling data, 1906-1953: Nevada Bureau of Mines Bulletin 52, 80 p.

Longwell, C. R., 1928, Geology of the Muddy Mountains, Nevada, with a section through the Virgin Range to the Grand Wash Cliffs, Arizona: U.S. Geological Survey Bulletin 798, $152 \mathrm{p}$.

1936, Geology of the Boulder reservoir floor, Arizona-Nevada: Geological Society of America Bulletin, v. 47, p. 1393-1476.

Longwell, C. R., Pampeyan, E. H., Bowyer, Ben, and Roberts, R. J., 1965, Geology and mineral deposits of Clark County, Nevada: Nevada Bureau of Mines Bulletin 62, $218 \mathrm{p}$.

Lori, Annibale, and Frosio, Giancarlo, 1962, Trent'anni di esercizio della galleria di derivazione idroelettrica IdroVorvano attraversante una formazione di anidrite: Com- municazione al $\mathrm{I}^{\circ}$ Coloquio Internacional sobre las Obras Publicas en los Terrenos Yesiferos, Madrid, September 24-29, 1962-Societa' Elettrica Bresciana, Brescia, Italy, 1962.

Lotze, Franz, 1957, Steinsalz und Kalisalze: Berlin, Gebrüder Borntraeger, $465 \mathrm{p}$.

Louisiana Department of Conservation, 1975, Louisiana salt domes-Potential for storage of crude oil: Louisiana Oil and Gas Division Publication, 42 p.

Love, J. D., 1948, Mesozoic stratigraphy of the Wind River basin, central Wyoming, in Wind River basin, 1948: Wyoming Geological Association Guidebook, 3rd Annual Field Conference, p. 96-111.

Love, J. D., Tourtelot, H. A., Johnson, C. O., Sharkey, H. H. R., Thompson, R. M., and Zapp, A. D., 1945, Stratigraphic sections and thickness maps of Jurassic rocks in central Wyoming: U.S. Geological Survey Oil and Gas Investigations Preliminary Chart OC-14.

MacLachlan, James, and Bieber, Alan, 1963, Permian and Pennsylvanian geology of the Hartville uplift-Alliance basin-Chadron arch area, in Guidebook to the geology of the northern Denver basin and adjacent uplifts, 1963: Rocky Mountain Association of Geologists Guidebook, 14th Field Conference, p. 84-94.

MacLachlan, M. E., 1972, Triassic System, in Geologic atlas of the Rocky Mountain region: Rocky Mountain Association of Geologists, p. 166-176.

Madison, R. J., 1970, Effects of a causeway on the chemistry of the brine in Great Salt Lake, Utah: Utah Geological and Mineralogical Survey Water-Resources Bulletin 14, 52 p.

Maher, J. C., 1960, Stratigraphic cross section of Paleozoic rocks, West Texas to northern Montana: American Association of Petroleum Geologists Cross Section Publication 2, $18 \mathrm{p}$.

Maher, P. D., 1976, The geology of the Pineview field area, Summit County, Utah, in Symposium on geology of the Cordilleran hingeline, 1976: Rocky Mountain Association of Geologists, p. 345-350.

Maiklem, W. R., Bebout, D. G., and Glaister, R. P., 1969, Classification of anhydrite-A practical approach: Bulletin of Canadian Petroleum Geology, v. 17, no. 2, p. 194-233.

Mallory, W. W., 1966, Cattle Creek anticline, a salt diapir near Glenwood Springs, Colorado, in Geological Survey research, 1966: U.S. Geological Survey Professional Paper 550-B, p. B12-B15.

1971, The Eagle Valley Evaporite, northwest Colorado-A regional synthesis: U.S. Geological Survey Bulletin 1311-E, 37 p.

1972, Regional synthesis of the Pennsylvanian System, in Geologic atlas of the Rocky Mountain region: Rocky Mountain Association of Geologists, p. 111-127.

1977, Regional aspects of the Eagle Valley Evaporite, in Veal, H. K., ed., Exploration frontiers of the central and southern Rockies: Rocky Mountain Association of Geologists, p. 191-196.

Mannion, L. E., 1963, Virgin Valley salt deposits, Clark County, Nevada, in First symposium on salt, 1962: Cleveland, Ohio, Northern Ohio Geological Society, p. 166-175. 
Mantek, William, 1973, Niagaran pinnacle reefs in Michigan, in Geology and the environment, 1973, Michigan Basin Geological Society Annual Field Excursion Guidebook, p. $35-46$.

Marafi, Hussein, 1972, Newburg-South Westhope oil fields, North Dakota, in King, R. E., ed., Stratigraphic oil and gas fields: American Association of Petroleum Geologists Memoir 16, p. 633-640.

Marshall, W. L., and Slusher, R., 1966, Thermodynamics of calcium sulfate dihydrate in aqueous sodium chloride solutions, $0-110^{\circ} \mathrm{C}$ : Journal of Physical Chemistry, v. 70, p. $4015-4027$.

1968, Aqueous systems at high temperature-Solubility to $200{ }^{\circ} \mathrm{C}$ of calcium sulfate and its hydrates in seawater and saline water concentrates and temperatureconcentration limits: Journal of Chemical and Engineering Data, v. 13, p. 83-93.

Marshall, W. L., Slusher, R., and Jones, E. V., 1964, Aqueous systems at high temperatures, XIV-Solubility and thermodynamic relationships for $\mathrm{CaSO}_{4}$ in $\mathrm{NaCl}-\mathrm{H}_{2} \mathrm{O}$ solutions from $40^{\circ}$ to $200^{\circ} \mathrm{C}, 0$ to 4 molal $\mathrm{NaCl}$ : Journal of Chemical and Engineering Data, v. 9, p. 187-191.

Martinez, J. D., 1974, Tectonic behavior of evaporites, in Coogan, A. H., ed., Fourth symposium on salt, 1974: Cleveland, Ohio, Northern Ohio Geological Society, v. 1, p. 155-168.

Martinez, J. D., Kupfer, D. J., Thoms, R. L., Smith, C. G., Jr., and Kolb, C. R., 1975, An investigation of the utility of Gulf Coast salt domes for storage or disposal of radioactive wastes: Prepared for Union Carbide Corporation, Nuclear Division, Oak Ridge National Laboratory, Y/OWI/SUB-4112/10, 204 p.

Martinez, J. D., Thoms, R. L., Kupfer, D. H., Smith, C. G. Jr., Kolb, C. R., Newchurch, E. J., Wilcox, R. E., Manning, T. A., Jr., Rombert, M., Lewis, A. J., and Rovik, J. E., 1976, An investigation of the utility of Gulf Coast salt domes for the storage or disposal of radioactive wastes: Prepared for Union Carbide Corporation, Nuclear Division, Oak Ridge National Laboratory, Y/OWI/SUB-4112/25, 329 p.

Marx, A. H., 1936, Hoskins Mound salt dome, Brazoria County, Texas: American Association of Petroleum Geologists Bulletin, v. 20, no. 2, p. $155-178$.

Mason, B. B., and others, 1971, Region 6-Western Gulf basin, in Future petroleum provinces of the United States - Their geology and potential: American Association of Petroleum Geologists Memoir 15, v. 2, p. 805-984.

Matthews, R. D., 1977, Evaporite cycles and lithofacies in Lucas Formation, Detroit River Group, Devonian, Midland, Michigan, in Fisher, J. H., ed., Recfs and evaporites-Concepts and depositional models: American Association of Petroleum Geologists Studies in Geology 5, p. 73-91.

Maughan, E. K., 1966, Environment of deposition of Permian salt in the Williston and Alliance basins, in Rau, J. L., ed., Second symposium on salt, 1965: Cleveland, Ohio, Northern Ohio Geological Society, v. 1, p. 35-47.

McDivitt, J. F., 1952, A report on gypsum deposits in Washington County, Idaho: Idaho Bureau of Mines and Geology Pamphlet 93, 15 p.
McGrain, Preston, and Helton, W. L., 1964, Gypsum and anhydrite in the St. Louis Limestone in northwestern Kentucky: Kentucky Geological Survey, Series X, Information Circular 13, 26 p.

McGregor, D. J., 1954, Gypsum and anhydrite deposits in southwestern Indiana: Indiana Geological Survey Report of Progress 8, $24 \mathrm{p}$.

McKee, E. D., Oriel, S. S., and others, 1967a, Paleotectonic maps of the Permian System: U.S. Geological Survey Miscellaneous Geologic Investigations Map I-450, 164 p. 1967b, Paleotectonic investigations of the Permian System in the United States: U.S. Geological Survey Professional Paper 515, 271 p.

McNamee, D. F., 1969, The Glen Rose reef complex of East Texas and central Louisiana: Gulf Coast Association of Geological Societies Transactions, v. 19, p. 11-21.

Meinzer, O. E., 1923, The occurrence of ground water in the United States, with a discussion of principles: U.S. Geological Survey Water-Supply Paper 489, 321 p.

Meinzer, O. E., Renick, B. C., and Bryan, Kirk, 1927, Geology of No. 3 Reservoir site of the Carlsbad irrigation project, New Mexico, with respect to water-tightness: U.S. Geological Survey Water-Supply Paper 580, p. 1-39.

Merriam, D. F., 1957, Notes on the Permian Stone Corral Formation of central and western Kansas: Compass, v. 34, p. 267-277.

Mesolella, K. J., 1978, Paleogeography of some Silurian and Devonian reef trends, central Appalachian basin: American Association of Petroleum Geologists Bulletin, v. 62 , p. $1607-1644$.

Mesolella, K. J., Robinson, J. D., McCormic, L. M., and Ormiston, A. R., 1974, Cyclic deposition of Silurian carbonates and evaporites in Michigan basin: American Association of Petroleum Geologists Bulletin, v. 58, p. 34-62.

Michigan Geological Survey, 1964, Stratigraphic succession in Michigan: Michigan Geological Survey Chart 1.

Momper, J. A., 1963, Nomenclature, lithofacies and genesis of Permo-Pennsylvanian rocks-Northern Denver basin, in Guidebook to the geology of the northern Denver basin and adjacent uplifts, 1963: Rocky Mountain Association of Gcologists Guidebook, 14th Field Conference, p. 41-67.

Moore, B. N., 1937, Nonmetallic mineral resources of eastern Oregon: U.S. Gcological Survey Bulletin 875, p. 7-8

Morey, G. W., and Hesselgesser, J. M., 1951, Solubility of some minerals in super-heated steam at high pressures: Economic Geology, v. 46, p. 821-855.

Morikawa, H., Minato, I., Tomita, T., and Iwai, S., 1975, Anhydrite-A refinement: Acta Crystallographica, v. B31, p. 2164-2165.

Morris, R. C., and Dickey, P. A., 1957, Modern evaporite deposition in Peru: American Association of Petroleum Geologists Bulletin, v. 41, p. 2467-2474.

Moulton, F. C., 1975, Lower Mesozoic and upper Paleozoic petroleum potential of the Hingeline area, central Utah, in Bolyard, D. W., ed., Deep drilling frontiers of the central Rocky Mountains-A symposium: Rocky Mountain Association of Geologists, p. 87-97. 
Mourant, W. A., and Shomaker, J. W., 1970, Reconnaissance of water resources of De Baca County, New Mexico: New Mexico Bureau of Mincs and Mineral Resources Ground-Water Report 10, 87 p.

Mueller, W. H., and Briegel, U., 1977, Experimental investigations on anhydrites: National Company for the Storage of Radioactive Wastes, Laboratory for Experimental Geology, Institute of Geology, Swiss Federal Institute of Technology, Zurich, Switzerland, $85 \mathrm{p}$.

Muir, J. L., 1934, Anhydrite-gypsum problem of Blaine Formation, Oklahoma: American Association of Petroleum Geologists Bulletin, v. 18, no. 10, p. 1297-1312.

Müller, Peter, and Siemes, Heinrich, 1974, Strength, ductibility, and preferred orientation of anhydrite under mantle pressure up to 5 kilobars at temperatures up to $300^{\circ} \mathrm{C}$ : Tectonophysics, v. 23, nos. 1-2, p. 105-127.

Müller, W. H., and Briegel, U., 1977, Experimental studies on anhydrite from Switzerland: Ecologae Geologicae Helvetiae (CHE) (EGHVAG), v. 70. no. 3, p. 685-699. 1978, The rheological behavior of polycrystalline anhydrite: Ecologae Geologicae Helvetiae (CHE) (EGH-VAG), v. 71, no. 2, p. 397-407.

Mundt, P. A., 1956, Heath-Amsden strata in central Montana: American Association of Petroleum Geologists Bulletin, v. 40 , p. $1915-1934$.

Murray, G. E., 1961, Geology of the Atlantic and Gulf Coastal Province of North America: New York, Harper, 692 p. 1966, Salt structures of Gulf of Mexico basin-A review: American Association of Petroleum Geologists Bulletin, v. 50, p. 439-478.

1968, Salt structures of Gulf of Mexico basin-A review, in Braunstein, J., and O'Brien, G. D., eds., Diapirism and diapirs: American Association of Petroleum Geologists Memoir 8, p. 99-121.

Murray, R. C., 1964, Origin and diagenesis of gypsum and anhydrite: Journal of Sedimentary Petrology, v. 34, p. 512-523.

Mytton, J. W., 1973, Two salt structures in Arizona-The Supai salt basin and the Luke salt body: U.S. Geological Survey Open-file report, $40 \mathrm{p}$.

Naumov, G. B., Ryzhenko, B. N., and Khodakovsky, I. L., 1971, Handbook of thermodynamic data: Moscow, Atomizdat, 328 p.

Netherland, Sewcll and Associates, Inc., 1976a, Geologic study of the interior salt domes of northeast Texas salt-dome basin to investigate their suitability for possible storage of radioactive waste material as of May, 1976: Prepared for Union Carbide Corporation, Nuclear Division, Oak Ridge National Laboratory, ORNL/SUB-76/99939.

$1976 \mathrm{~b}$, Compilation of basic geologic and hydrologic data for the Mississippi salt domes as of September, 1976: Prepared for Union Carbide Corporation, Nuclear Division, Oak Ridge National Laboratory, ORNL/SUB-76/16511.

1977, Geologic investigation of the Virgin River Valley salt deposits, Clark County, southeastern Nevada, to investigate their suitability for possible storage of radioactive waste material, as of September, 1977: Prepared for Union Carbide Corporation, Nuclear Division, Oak Ridge National Laboratory, Y/OWI/SUB-77/223328.

Newcombe, R. B., 1928, Non-metallic minerals, review of industries and production, in Mineral resources of Michigan: Michigan Department of Conservation, Geological Survey Division Publication 37, Geologic Series 31, p. 103-108.

Newkirk, T. F., 1971, Possible future petroleum potential of Jurassic, western Gulf basin, in Future petroleum provinces of the United States-Their geology and their potential: American Association of Petroleum Geologists Memoir 15, v. 2, p. 927-953.

Newland, D. H., 1929, The gypsum resources and gypsum industry of New York: New York State Museum Bulletin 283, 188 p.

Newland, D. H., and Leighton, Henry, 1910, Gypsum deposits of New York: New York State Museum Bulletin 143, $94 \mathrm{p}$.

Nurmi, R. D., and Friedman, G. M., 1977, Sedimentology and depositional environments of basin-center evaporites, lower Salina Group (Upper Silurian), Michigan basin, in Fisher, J. H., ed., Reefs and evaporites-Concepts and depositional models: American Association of Petroleum Geologists Studies in Geology 5, p. 23-52.

Ochsenius, Carl, 1877, Die Bildung der Steinsalzlager und ihrer Mutter laugensalze: Halle, C.E.M. Pfeffer, 172 p.

O'Donnell, Lawrence, 1935, Jefferson Island salt dome, Iberia Parish, Louisiana: American Association of Petroleum Geologists Bulletin, v. 19, no. 11, p. 1602-1644.

Oglesby, W. R., 1967, A gravity profile of the south Florida shelf: Gulf Coast Association of Geological Societies Transactions, v. 17, p. 278-286.

Olive, W. W., 1957, Solution-subsidence troughs, Castile Formation of Gypsum Plain, Texas and New Mexico: Geological Society of America Bulletin, v. 68, no. 3, p. 351-358.

Olson, R. H., 1964, Gypsum and anhydrite, in Mineral and water resources of Nevada: Nevada Bureau of Mines Bulletin 65, p. 209-213.

Oxley, M. L., Minihan, E. D., and Ridgeway, J. M., 1967, A study of the Jurassic sediments in portions of Mississippi and Alabama: Gulf Coast Association of Geological Societies Transactions, v. 17, p. 24-48.

Parker, V. B., Wagman, D. D., and Evans, W. H., 1971, Selected values of chimical thermodynamic propertiesTables for the alkaline earth elements (Element 92 through 97 in the standard order of arrangement): U.S. National Bureau of Standards Technical Note 270-6, $106 \mathrm{p}$.

Partridge, E. P., and White, A. H., 1929, The solubility of calcium sulfate from $0^{\circ}$ to $100^{\circ} \mathrm{C}$ : Journal of the American Chemical Society, v. 51, p. 360-370.

Peirce, H. W., 1972, Red Lake salt mass: Arizona Bureau of Mines Fieldnotes, v. 2, no. 1, p. 4-5.

1973, Evaporite developments; thickest anhydrite in the world? Arizona Bureau of Mines Fieldnotes, v. 3, no. 2, p. 1-2. 
1974, Thick evaporites in the Basin and Range Province-Arizona, in Coogan, A. H., ed., Fourth symposium on salt, 1973: Cleveland, Ohio, Northern Ohio Geological Society, v. 1, p. 47-55.

1976, Tectonic significance of Basin and Range thick evaporite deposits: Arizona Geological Society Digest, v. 10, March, p. 325-339.

Peirce, H. W., and Gerrard, T. A., 1966, Evaporite deposits of the Permian Holbrook basin, Arizona, in Rau, J. L., ed., Second symposium on salt, 1973: Cleveland, Ohio, Northern Ohio Geological Society, v. 1, p. 1-10.

Perova, A. P., 1970a, The polyhalite crystallization volume in $\mathrm{Ca}, \mathrm{K}, \mathrm{Mg} / \mathrm{SO}_{4}-\mathrm{H}_{2} \mathrm{O}$ quinary system at $25^{\circ}$ and $55^{\circ} \mathrm{C}$ : Russian Journal of Inorganic Chemistry, v. 15 , p. 844-846.

$1970 \mathrm{~b}$, Crystallization regions of schonite, leonite and kainite in the $\mathrm{Ca}, \mathrm{K}, \mathrm{Mg} / \mathrm{Cl}, \mathrm{SO}_{4}-\mathrm{H}_{2} \mathrm{O}$ quinary system at $25^{\circ}$ and $55^{\circ} \mathrm{C}$ : Russian Journal of Inorganic Chemistry, v. 15, p. 987-991.

Perry, E. S., 1949, Gypsum, lime, and limestone in Montana: Montana Bureau of Mines and Geology Memoir 29, $45 \mathrm{p}$.

Perry, T. C., 1971, Economic geology and petrology of the Mississippian gypsum/anhydrite of Iowa: Iowa City, Iowa, University of Iowa M.S. thesis, 152 p.

Peterson, J. A., 1957a, Gypsum Spring and Sundance Formations, central Wyoming, in Southwest Wind River basin: Wyoming Geological Association Guidebook, 12th Annual Field Conference, 1957, p. 47-54.

1957b, Marine Jurassic of northern Rocky Mountains and Williston basin: American Association of Petroleum Geologists Bulletin, v. 41, p. 399-440.

1966, Sedimentary history of the Sweetgrass arch, in Jurassic and Cretaceous stratigraphic traps, Sweetgrass Arch: Billings Geological Society Guidebook, 17th annual field conference, 1966, p. 112-134.

1972, Jurassic System, in Geologic atlas of the Rocky Mountain region: Rocky Mountain Association of Geologists, p. 177-189.

Peterson, J. A., and Hite, R. J., 1969, Pennsylvanian evaporitecarbonate cycles and their relation to petroleum occurrence, southern Rocky Mountains: American Association of Petroleum Geologists Bulletin, v. 53, p. 884-908.

Peterson, J. A., Loleit, A. J., Spencer, C. W., and Ullrich, R. A., 1965 , Sedimentary history and economic geology of San Juan basin, New Mexico and Colorado, in Galley, J. E., ed., Subsurface disposal in geologic basins-A study of reservoir strata: American Association of Petroleum Geologists Memoir 10, p. 186-231. Reprinted, with revisions, from American Association of Petroleum Geologists Bulletin, v. 49, p. 2076-2119 (1965).

Pierce, W. G., and Rich, E. I., 1962, Summary of rock salt deposits in the United States as possible storage sites for radioactive waste materials: U.S. Gcological Survey Bulletin 1148, $91 \mathrm{p}$.

Poindexter, O. F., Martin, H. M., and Bergquist, S. G., 1951, Rocks and minerals of Michigan (revised): Michigan Geological Survey Publication 42, 3d ed., p. 61, 66, 90, 102.
Posnjak, E., 1940, Deposition of calcium sulfate from sea water: American Journal of Science, v. 238, p. 559-568.

Powers, D. W., Lambert, S. J., Shaffer, S., Hill, L. R., and Weart, W. D., eds., 1978, Geological characterization report, Waste Isolation Pilot Plant (WIPP) site, southeastern New Mexico, 2 vols.: prepared for U.S. Department of Energy by Sandia Laboratories, SAND 78-1596.

Pratt, A. R., Heylmun, E. B., and Cohenour, R. E., 1966, Salt deposits of Sevier Valley, Utah, in Rau, J. L., ed., Second symposium on salt, 1965: Cleveland, Ohio, Northern Ohio Geological Society, v. 1, p. 48-58.

Privrasky, N. C., Strecker, J. R., Grieshaber, C. E., and Byrne, Frank, 1958, Preliminary report on the Goose Egg and Chugwater Formations in the Powder River basin, Wyoming, in Powder River basin: Wyoming Geological Association Guidebook, 13th Annual Field Conference, 1958 , p. $48-55$.

Rainwater, E. H., 1970a, Stratigraphy and petroleum potential of peninsular Florida and southern Georgia: Gulf Coast Association of Geological Societies Transactions, v. 20, p. 49-59.

$1970 \mathrm{~b}$, Regional stratigraphy and petroleum potential of the Gulf Coast Lower Cretaceous: Gulf Coast Association of Geological Societies Transactions, v. 20, p. 145-157.

1971a, Possible future petroleum potential of Lower Cretaceous, western Gulf basin, in Cram, I. H., ed., Future petroleum provinces of the United States-Their geology and potential: American Association of Petroleum Geologists Memoir 15, v. 2, p. 901-926.

1971b, Possible future petroleum potential of peninsular Florida and adjacent continental shelves, in Cram, I. H., ed., Future petroleum provinces of the United States-Their geology and potential: American Association of Petroleum Geologists Memoir 15, v. 2, p. 1131-1345.

Ramez, M.R.H., 1976, Mechanism of intragranular gliding in experimentally deformed anhydrite: Neues Jahrbuch für Mineralogie Abhandlungen (Deu) (NJMIAK), v. 127, no. 3, p. 311-329.

Ransdell, L. S., and Partridge, E. P., 1929, The crystal forms of calcium sulphate: American Mineralogist, v. 14, p. 59.

Rascoe, Bailey, Jr., and Baars, D. L., 1972, Permian System, in Geologic atlas of the Rocky Mountain region: Rocky Mountain Association of Geologists, p. 143-165.

Raup, O. B., 1970, Brine mixing; an additional mechanism for formation of basin evaporites: American Association of Petroleum Geologists Bulletin, v. 54, p. 2246-2259.

Ravich, M. I., 1974, Water-salt systems at elevated temperatures and pressures: Nauka, Moscow, $151 \mathrm{p}$.

Rawson, R. R., 1969, Petrographic analysis of the "Kibbey Limestone," in Montana Geological Society, 20th annual conference, Eastern Montana symposium, 1969: p. $165-177$.

Rawson, R. R., and Turner, C. E., 1974, The Toroweap Formation-A new look, in Geology of northern Arizona, with notes on archaeology and paleoclimate, part 1-Regional studies: Northern Arizona University, 
Museum of Northern Arizona, and U.S. Geological Survey; prepared for Geological Society of America, Rocky Mountain Section Meeting, Flagstaff, 1974, p. 155-190.

Raymer, L. L., and Biggs, W. P., 1963, Matrix characteristics defined by porosity computations: Society of Professional Well Log Analysts Transactions, v. 4, chapter X, p. X-1 to $\mathrm{X}-21$.

Reed, H. E., 1963, Salt deposits in the Williston basin-United States portion, in First symposium on salt, Cleveland, Ohio, 1962: Northern Ohio Geological Society, p. 147-165.

Reeder, H. O., and Thatcher, L. L., 1963, Tritium used as a ground-water tracer between Lake McMillian and Major Johnson Springs, Eddy County, New Mexico: U.S. Geological Survey Report TEI-839, 120 p.

Rickard, L. V., 1969, Stratigraphy of the Upper Silurian Salina Group, New York, Pennsylvania, Ohio, Ontario: New York State Museum and Science Service Map and Chart Series $12,57 \mathrm{p}$.

Ritter, D. F., 1967, Rates of denudation: Journal of Geological Education, v. 15, p. 154-159.

Robertson, E. C., 1979, Thermal conductivities of rocks: U.S. Geological Survey Open-File Report 79-356, 52 p.

Robie, R. A., Hemingway, B. S., and Fisher, J. R., 1978, Thermodynamic properties of minerals and related substances at $298.15 \mathrm{~K}$ and 1 bar $\left(10^{5}\right.$ Pascals $)$ pressure and at higher temperatures: U.S. Geological Survey Bulletin 1452, 456 p.

Rooney, L. F., and French, R. R., 1968, Allogenic quartz and the origin of penemosaic texture in evaporites in the Detroit River Formation (Middle Devonian) in northern Indiana: Journal of Sedimentary Petrology, v. 38, p. 755-765.

Rose, P. R., 1972, Edwards Group, surface and subsurface, central Texas: Texas Bureau of Economic Geology Report of Investigations 74, 198 p.

Roth, E. E., 1968, Natural gases of Appalachian basin, in Beebe, B. W., and Curtis, B. F., eds., Natural gases of North America: Tulsa, Okla., American Association of Petroleum Geologists Memoir 9, v. 2, p. 1702-1715.

Rowe, J. J., Morey, G. W., and Zen, C. S., 1972, The quinary reciprocal salt system $\mathrm{Na}, \mathrm{K}, \mathrm{Mg}, \mathrm{Ca} / \mathrm{Cl}, \mathrm{SO}_{4}-\mathrm{A}$ review of the literature with new data: U.S. Geological Survey Professional Paper 741, 37 p.

Runvik, R. C., 1972, Mineral resources development in the public domain-An unfinished case history, in Eighth forum on geology of industrial minerals, Iowa City, Iowa, 1972, Proceedings: Iowa Geological Survey Public Information Circular 5, p. 159-183.

Rybach, Ladislaus, 1975, Thermal problems in the storage of radioactive wastes in anhydrite: Vereinigung Schweizeischer Petroleum-Geologen und Ingenieure Bulletin, v. 41, no. 100, p. 1-13.

Sahores, Jean, 1962, Contribution á létude des phénoménes mécaniques accompagnant l'hydration de l'anhydrite: Paris, Centre détudes et de Recherches de Lindustrie des Liants Hydrauliques, Publication Technical no. 126, 230 p.
Sandberg, C. A., 1961, Distribution and thickness of Devonian rocks in Williston basin and in central Montana and north-central Wyoming: U.S. Geological Survey Bulletin 1112-D, p. 105-127.

1962, Geology of the Williston basin, North Dakota, Montana, and South Dakota, with reference to subsurface disposal of radioactive waste: U.S. Geological Survey Report TEI-809, 148 p.

Sandberg, C. A., and Hammond, C. R., 1958, Devonian System in Williston basin and central Montana: American Association of Petroleum Geologists Bulletin, v. 42, p. 2293-2334.

Sandberg, C. A., and Mapel, W. J., 1967, Devonian of the northern Rocky Mountains and plains, in Oswald, D. H., ed., International symposium on the Devonian System, Calgary, 1967: Alberta Society of Petroleum Geologists, v. 1 , p. $843-877$.

Sandberg, C. A., and Poole, F. G., 1977, Conodont biostratigraphy and depositional complexes of Upper Devonian cratonic-platform and continental-shelf rocks in the western United States, in Murphy, M. A., and others, eds., Western North America; Devonian: Riverside, Calif., California University, Campus Museum Contributions 4 , p. 144-182.

Santos, E. S., 1975, Lithology and uranium potential of Jurassic formations in the San Ysidro-Cuba and Majors Ranch areas, northwestern New Mexico: U.S. Geological Survey Bulletin 1329, 22 p.

Sarg, J. F., 1977, Sedimentology of the carbonate-evaporite facies transition of the Seven Rivers Formation (Guadalupian, Permian) in southeast New Mexico, in Upper Guadalupian facies Permian reef complex, Guadalupe Mountains, New Mexico and west Texas: Society of Economic Paleontologists and Mineralogists, Permian Basin section, 1977 Field Conference Guidebook, Publication 77-16, p. 451-478.

Saxby, D. B., and Lamar, J. E., 1957, Gypsum and anhydrite in Illinois: Illinois State Geological Survey Circular 226, $26 \mathrm{p}$.

Schmalz, R. F., 1969, Deep-water evaporite deposition-A genetic model: American Association of Petroleum Geologists Bulletin, v. 53, p. 798-823.

Schumaker, R. D., 1966, Regional study of Kansas Permian evaporite formations: Wichita, Kans., Wichita State University, M. S. thesis, 87 p.

Schwerdtner, W. M., 1973, Schistosity in deformed anhydrite-A reinterpretation [abs.]: International Symposium Salt Techniques Program Book 4, p. 25.

Schwerdtner, W. M., Tou, J. C., and Hertz, P. B., 1965, Elastic properties of single crystals of anhydrite: Canadian Journal of Earth Sciences, v. 2, no. 6, p. 673-683.

Scruton, P. C., 1953, Deposition of evaporites: American Association of Petroleum Geologists Bulletin, v. 37, p. 2498-2512.

Seipold, U., and Gutzeit, W., 1974, Investigations of the pressure-dependence of thermal conductivity in certain rocks: Gerlands Beiträge zur Geophysik, v. 83, no. 6, p. 498-504. 
Sendlein, L.V.A., 1973, Geology of the U.S. Gypsum Sperry, Iowa mine, in Eighth forum on the geology of industrial minerals, Iowa City, Iowa, 1973, Proceedings: Iowa Geological Survey Public Information Circular 5, p. 67-87.

Serne, R. J., Rai, D., Mason, M. J., and Molecke, M. A., 1977, Batch Kd measurements of nuclides to estimate migration potential at the proposed Waste Isolation Pilot Plant in New Mexico: Battelle-Pacific Northwest Laboratories Report PNL-2448, 81 p.

Sharma, G. D., 1966, Geology of Peters Reef, St. Clair County, Michigan: American Association of Petroleum Geologists Bulletin, v. 50, no. 2, p. 327-350.

Shearman, D. J., 1966, Origin of marine evaporites by diagenesis: Transactions of the Institution of Mining and Metallurgy, sec. B, v. 75, p. 208-215.

Shearman, D. J., and Fuller, J. G., 1969, Anhydrite diagenesis, calcitization, and organic laminites, Winnipegosis Formation, middle Devonian, Saskatchewan: Bulletin of Canadian Petroleum Geology, v. 17, no. 4, p. 496-525.

Shearman, D. J., Mossop, G., Dunsmore, H., and Martin W., 1972, Origin of gypsum veins by hydraulic fracture: Transactions of the Institution of Mining and Metallurgy, sec. B, v. 81, p. 149-155.

Shoemaker, E. M., Case, J. E., and Elston, D. P., 1958, Salt anticlines of the Paradox basin, in Sanborn, A. F., ed., Guidebook to the geology of the Paradox basin, 1958: Intermountain Association of Petroleum Geologists, 9th Annual Field Conference, p. 39-59.

Shreiner, L. A., Baydyuk, B. V., and Pavlova, N. N., 1967, Deformational properties of rock as applied to petroleum geology and deep hole drilling: Proceedings of the seventh world petroleum congress, v. 3, Drilling and production: New York, Elsevier, p. 27-39.

Shreveport Geological Society, 1947, 1945 reference report on certain oil and gas fields of north Louisiana, south Arkansas, Mississippi, and Alabama, v. II: Shreveport Geological Society, 205 p.

Sloss, L. L., 1973, The significance of evaporites: Journal of Sedimentary Petrology: v. 23, p. 143-161.

Sloss, L. L., and Laird, W. M., 1947, Devonian System in northwestern Montana: American Association of Petroleum Geologists Bulletin, v. 31, p. 1404-1430.

Smith, G. I., Jones, C. L., Cuberttson, W. C., Ericksen, G. E., and Dyni, J. R., 1973, Evaporites and brines, in Brobst, D. A., and Pratt, W. D., eds., United States mineral resources: U.S. Geological Survey Professional Paper 820, p. 197-216.

Smith, G. W., Summers, G. E., Jr., Wallington, Dale, and Lee, J. L., 1958, Mississippian oil reservoirs in Williston basin, in Weeks, L. G., ed., Habitat of oils-A symposium: Tulsa, Okla., American Association of Petroleum Geologists, p. 149-177.

Smith, R. A., and Stone, R. W., 1920, Michigan, in Stone, R. W., Gypsum deposits of the United States: U.S. Geological Survey Bulletin 697, p. 122-129.

Smith, Russell, ed., 1967, Stratigraphic cross section of Paleozoic rocks, Oklahoma to Saskatchewan: American Association of Petroleum Geologists Cross Section Publication 5, 23 p.
Smosna, R. A., and Patchen, D. G., 1978, Silurian evolution of central Appalachian basin: American Association of Petroleum Geologists Bulletin, v. 62, p. 2308-2328.

Smosna, R. A., Patchen, D. G., Warshauer, S. M., and Perry, W. J., Jr., 1977, Relationships between depositional environments, Tonoloway Limestone, and distribution of evaporites in the Salina Formation, West Virginia, in Fisher, J. H., ed., Reefs and evaporites-Concepts and depositional models: American Association of Petroleum Geologists Studies in Geology 5, p. 125-143.

Snider, H. I., 1966, Stratigraphy and associated tectonics of the Upper Permian Castile-Salado-Rustler evaporite complex, Delaware basin, west Texas and southeast New Mexico: Albuquerque, N. Mex., University of New Mexico Ph.D. thesis, 196 p.

Spooner, W. C., 1926, The interior salt domes of Louisiana: American Association of Petroleum Geologists Bulletin, v. 10, p. 217-292.

1935, Oil and gas geology of the Gulf Coastal Plain in Arkansas: Arkansas Geological Survey Bulletin 2 [not a State report], Little Rock, Ark., Parke-Harper Printing Co. $516 \mathrm{p}$.

Stanley, K. O., and Collinson, J. W., 1979, Depositional history of Paleocene-lower Eocene Flagstaff Limestone and coeval rocks, central Utah: American Association of Petroleum Geologists Bulletin, v. 63, p. 311-323.

Stapor, F. W., Jr., 1972, Origin of the Todilto gypsum mounds in the Ghost Ranch area, north-central New Mexico: Mountain Geologist, v. 9, p. 59-63.

Stenzel, H. B., 1943, Gypsum resources and mining on the Hockley Dome, Harris County, Texas, in Texas mineral resources: University of Texas Publication 4301, p. 207-226.

Stephens, D. R., 1964, The hydrostatic compression of eight rocks: Journal of Geophysical Research, v. 69, no. 14, p. 2967-2978.

Stewart, D. B., and Potter, R. W. II, 1979, Application of physical chemistry of fluids in rock salt at elevated temperature and pressure to repositories for radioactive waste, in McCarthy, G. J., ed., Scientific basis for nuclear waste management, v. 1: New York, Plenum Press, p. 297-312.

Stone, R. W., and others, 1920, Gypsum deposits of the United States: U.S. Geological Survey Bulletin, 697, 326 p.

Story, J. A., and Howell, D. H., 1963, Gypsum deposits of the northern Colorado Front Range, in Guidebook to the geology of the northern Denver basin and adjacent uplifts: Rocky Mountain Association of Geologists Guidebook, 14th field conference, 1963, p. 258-263.

Summers, W. K., and Kottlowski, F. E., eds., 1969, The San Andres Limestone, a reservoir for oil and water in New Mexico-A symposium: New Mexico Geological Society Special Publication 3, 51 p.

Sutton, D. G., 1968, Headquarters field, in Symposium on Michigan oil and gas fields: Michigan Basin Geological Society, p. 99-114.

Swain, F. M., 1949, Upper Jurassic of northeastern Texas: American Association of Petroleum Geologists Bulletin, v. 33 , p. $1206-1250$ 
Swanson, H. E., Fuyat, R. K., and Ugrinie, G. M., 1955, Standard X-ray diffraction powder patterns: National Burcau of Standards Circular 539, v. IV, p. 65-67.

Tait, D. B., Ahlen, J. L., Gordon, A., Scott, G. L., Motts, W. S., and Spitler, M. E., 1962, Artesia Group of New Mexico and West Texas: American Association of Petroleum Geologists Bulletin, v. 46, p. 504-517.

Tanner, W. F., 1970, Triassic-Jurassic lakes in New Mexico: Mountain Geologist, v. 7, p. 281-289.

1972, Large gypsum mounds in the Todilto Formation, New Mexico: Mountain Geologist, v. 9, p. 55-58.

Taylor, R. E., 1937, Water-insoluble residues in rock salt of Louisiana salt plugs: American Association of Petroleum Geologists Bulletin, v. 21, p. 1268-1310.

1938, Origin of the cap rock of Louisiana salt domes: Louisiana Geological Survey Bulletin 11, $191 \mathrm{p}$.

Tazlieff, H., 1970, The Afar Triangle: Scientific American, February 1970 , p. 33-41.

Twenter, F. R., and Metzger, D. G., 1963, Geology and ground water in Verde Valley-The Mogollon Rim region, Arizona: U.S. Geological Survey Bulletin 1177, 132 p.

Udden, J. A., 1924, Laminated anhydrite in Texas: Geological Socicty of America Bulletin, v. 35, p. 347-354.

Ulteig, J. R., 1964, Upper Niagaran and Cayugan stratigraphy of northeastern Ohio and adjacent areas: Ohio Geological Survey Report of Investigations 51, 48 p.

Vanderburg, W. O., 1937, Reconnaissance of mining districts in Clark County, Nev.: U.S. Bureau of Mines Information Circular 6964, 81 p.

Ver Planck, W. E., 1952, Gypsum in California: California Division of Mines and Geology Bulletin 163, $151 \mathrm{p}$. 1957, Gypsum, in Mineral commodities of California: California Division of Mines and Geology Bulletin 176, p. 231-240.

Waldschmidt, W. A., Fitzgerald, P. E., Lunsford, C. L., 1956, Classification of porosity and fractures in reservoir rocks: American Association of Petroleum Geologists Bulletin, v. 40, no. 5, p. 953-974.

Walker, C. W., 1974, Nature and origin of cap rock overlying Gulf Coast salt domes, in Coogan, A. H., ed., Fourth symposium on salt, Houston, Tex., 1973: Cleveland, Ohio, Northern Ohio Geological Society, v. 1, p. 169-195.

Walters, R. F., 1976, Land subsidence in central Kansas associated with rock salt dissolution: Flossmoor, Ill., Solution Mining Research Institute, Inc., 144 p. 1978, Land subsidence in central Kansas related to salt dissolution: Kansas Gcological Survey Bulletin 214, 82 p.

Wardlaw, N. C., and Schwerdtner, W. M., 1966, Haliteanhydrite seasonal layers in the Middle Devonian Prairie Evaporite Formation, Saskatchewan, Canada: Gcological Society of America Bulletin, v. 77, p. 331-342.

Weber, R. H., and Kottlowski, F. E., 1959, Gypsum resources of New Mexico: New Mexico Bureau of Mines and Mineral Resources Bulletin 68, 68 p.

West, I. M., 1964, Evaporite diagenesis in the Lower Purbeck beds of Dorset: Proceedings of the Yorkshire Geological Society, v. 34, p. 315-326, 330.
West Texas Gcological Society, 1960, Geology of the Delaware basin and field trip guidebook: Midland, Tex., West Texas Geological Society, 97 p.

Wheildon, J., Evans, T. R., and Girden, R. W., 1974, Thermal conductivity, density, and sonic velocity measurements of samples of anhydrite and halite from sites 225 and 227 , in Initial reports of the Deep Sea Drilling Project, v. 23: Washington, U.S. Government Printing Office, p. 909-911.

Whelan, J. A., 1972, Ochsenius bar theory of saline deposition supported by quantitative data, Great Salt Lake, Utah: International Geological Congress, 24th, Montreal, 1972, sec. 10, Geochemistry, p. 296-303.

Wilson, H. H., 1975, Subsalt origin of exotic blocks in piercement domes reveals the probability of Oligo-Miocene salt in the Gulf of Mexico region: Gulf Coast Association of Geological Societics Transactions, v. 25, p. 1-19.

Wilson, W. E., Rosenhein, J. S., and Hunn, J. D., 1973, Hydrologic evaluation of industrial waste injection at Mulberry, Florida, in Underground waste management and artificial recharge, v. 1: Tulsa, Okla., American Association of Petroleum Geologists, p. 552-564.

Winston, G. O., 1971, Regional structure, stratigraphy, and oil possibilities of the South Florida basin: Gulf Coast Association of Geological Societies Transactions, v. 21, p. 15-29.

1976, Six proposed formations in the undefined portion of the Lower Cretaceous section in south Florida: Gulf Coast Association of Geological Socicties Transactions, v. 26, p. 69-72.

Winter, J. A., 1962, Fredericksburg and Washita strata (subsurface Lower Cretaceous) southwest Texas, in Contributions to geology of south Texas: South Texas Geological Society, p. 81-115.

Wirth, 1968, Enterprise field, in Symposium on Michigan oil and gas fields, 1968: Michigan Basin Geological Society, p. 87-98.

Withington, C. F., 1962, Gypsum and anhydrite in the United States, exclusive of Alaska and Hawaii: U.S. Geological Survey Mineral Investigations Resource Map MR-33. 1964, Gypsum and anhydrite, in Mineral and water resources of Utah: Utah Geological and Mineralogical Survey Bulletin 73, p. 177-185.

1965, Suggestions for prospecting for evaporite deposits in southwestern Virginia: U.S. Geological Survey Professional Paper 525-B, p. B29-B33.

1966, Gypsum and anhydrite, in Mineral resources of California: California Division of Mines and Geology Bulletin 191, p. 188-198.

Withington, C. F., and Jaster, M. C., 1960, Selected annotated bibliography of gypsum and anhydrite in the United States and Puerto Rico: U.S. Geological Survey Bulletin $1105,126 \mathrm{p}$.

Woodward, H. P., 1958, Emplacement of oil and gas in Appalachian basin, in Weeks, L. G., ed., Habitat of oil-A symposium: Tulsa, Okla., American Association of Petroleum Geologists, p. 494-510. 
Woodward, L. A., and Callender, J. F., 1977, Tectonic framework of the San Juan basin, 1977: New Mexico Geological Society Guidebook, 28th Field Conference, p. 209-212.

Zdanovskii, A.B., 1949, Heterogeneous salt equilibria: Trudy Vsesoyuznogo Nauchno-Issledovatel skogo Geologicheskogo Instituta, v. 21, p. 336-358.
Zen, E-An, 1965, Solubility measurements in the system $\mathrm{CaSO}_{4}-\mathrm{NaCl}-\mathrm{H}_{2} \mathrm{O}$ at $35^{\circ}, 50^{\circ}$, and $75{ }^{\circ} \mathrm{C}$ and one atmosphere pressure: Journal of Petrology, v. 6, p. 124-164.

Zierfuss, H., 1969, Heat conductivity of some carbonate rocks and clayey sandstones: American Association of Petroleum Geologists Bulletin, v. 53, no. 2, p. 251-260. 


\section{SELECTED SERIES OF U.S. GEOLOGICAL SURVEY PUBLICATIONS}

\section{Perlodicals}

Earthquakes \& Volcanoes (issued bimonthly).

Preliminary Determination of Epicenters (issued monthly).

\section{Technical Books and Reports}

Professional Papers are mainly comprehensive scientific reports of wide and lasting interest and importance to professional scientists and engineers. Included are reports on the results of resource studies and of topographic, hydrologic, and geologic investigations. They also include collections of related papers addressing different aspects of a single scientific topic.

Bulletins contain significant data and interpretations that are of lasting scientific interest but are generally more limited in scope or geographic coverage than Professional Papers. They include the results of resource studies and of geologic and topographic investigations; as well as collections of short papers related to a specific topic.

Water-Supply Papers are comprehensive reports that present significant interpretive results of hydrologic investigations of wide interest to professional geologists, hydrologists, and engineers. The series covers investigations in all phases of hydrology, including hydrogeology, availability of water, quality of water, and use of water.

Circulars present administrative information or important scientific information of wide popular interest in a format designed for distribution at no cost to the public. Information is usually of short-term interest.

Water-Resources Investigations Reports are papers of an interpretive nature made available to the public outside the formal USGS publications series. Copies are reproduced on request unlike formal USGS publications, and they are also available for public inspection at depositories indicated in USGS catalogs.

Open-File Reports include unpublished manuscript reports, maps, and other material that are made available for public consultation at depositories. They are a nonpermanent form of publication that may be cited in other publications as sources of information.

\section{Maps}

Geologic Quadrangle Maps are multicolor geologic maps on topographic bases in 71/2- or 15-minute quadrangle formats (scales mainly $1: 24,000$ or $1: 62,500$ ) showing bedrock, surficial, or engineering geology. Maps generally include brief texts; some maps include structure and columnar sections only.

Geophysical Investigations Maps are on topographic or planimetric bases at various scales; they show results of surveys using geophysical techniques, such as gravity, magnetic, seismic, or radioactivity, which reflect subsurface structures that are of economic or geologic significance. Many maps include correlations with the geology.

Miscellaneous Investigations Series Maps are on planimetric or topographic bases of regular and irregular areas at various scales; they present a wide variety of format and subject matter. The series also includes 7 1/2-minute quadrangle photogeologic maps on planimetric bases which show geology as interpreted from aerial photographs. Series also includes maps of Mars and the Moon.
Coal Investigations Maps are geologic maps on topographic or planimetric bases at various scales showing bedrock or surficial geology, stratigraphy, and structural relations in certain coal-resource areas.

Oll and Gas Investigations Charts show stratigraphic information for certain oil and gas fields and other areas having petroleum potential.

Miscellaneous Field Studies Maps are multicolor or black-andwhite maps on topographic or planimetric bases on quadrangle or irregular areas at various scales. Pre-1971 maps show bedrock geology in relation to specific mining or mineral-deposit problems; post-1971 maps are primarily black-and-white maps on various subjects such as environmental studies or wilderness mineral investigations.

Hydrologic Investigations A tlases are multicolored or black-andwhite maps on topographic or planimetric bases presenting a wide range of geohydrologic data of both regular and irregular areas; principal scale is $1: 24,000$ and regional studies are at $1: 250,000$ scale or smaller.

\section{Catalogs}

Permanent catalogs, as well as some others, giving comprehensive listings of U.S. Geological Survey publications are available under the conditions indicated below from the U.S. Geological Survey, Books and Open-File Reports Section, Federal Center, Box 25425, Denver, CO 80225 . (See latest Price and Availability List.)

"Publications of the Geological Survey, 1879-1961" may be purchased by mail and over the counter in paperback book form and as a set of microfiche.

"Publications of the Geological Survey, 1962-1970" may be purchased by mail and over the counter in paperback book form and as a set of microfiche.

"Publications of the U.S. Geological Survey, 1971- 1981" may be purchased by mail and over the counter in paperback book form (two volumes, publications listing and index) and as a set of microfiche.

Supplements for 1982, 1983, 1984, 1985, 1986, and for subsequent years since the last permanent catalog may be purchased by mail and over the counter in paperback book form.

State catalogs, "List of U.S. Geological Survey Geologic and Water-Supply Reports and Maps For (State)," may be purchased by mail and over the counter in paperback booklet form only

"Price and Availability List of U.S. Geological Survey Publications," issued annually, is available free of charge in paperback booklet form only.

Selected coples of a monthly catalog "New Publications of the U.S. Geological Survey" available free of charge by mail or may be obtained over the counter in paperback booklet form only. Those wishing a free subscription to the monthly catalog "New Publications of the U.S. Geological Survey" should write to the U.S. Geological Survey, 582 National Center, Reston, VA 22092.

Note.--Prices of Government publications listed in older catalogs, announcements, and publications may be incorrect. Therefore, the prices charged may differ from the prices in catalogs, announcements, and publications. 
